\title{
Development and Gender Capital in India
}

The Indian state of Kerala has invoked much attention within development and gender debates, specifically in relation to its female capital - an outcome of interrelated historical, cultural and social practices. On the one hand, Kerala has been romanticised, with its citizenry, particularly women, being free of social divisions and uplifted through educational well-being. On the other hand, its realism is stark, particularly in the light of recent social changes.

Using a Bourdieusian frame of analysis, Development and Gender Capital in India explores the forces of globalisation and how they are embedded within power structures. Through narratives of women's lived experiences in the private and public domains, it highlights the "anomie of gender" through complexities and contradictions vis-à-vis processes of modernity, development and globalisation. By demonstrating the limits placed upon gender capital by structures of patriarchy and domination, it argues that discussions about the empowered Malayalee women should move from a mere "politics of rhetoric and representation" to a more embedded "politics of transformation", meaningfully taking into account women's changing roles and identities.

This book will be of interest to scholars and students of Development Studies, Gender Studies, Anthropology and Sociology.

Shoba Arun is Senior Lecturer in the Department of Sociology at the Manchester Metropolitan University, UK. 
Routledge Research on Asian Development

\section{Development and Gender Capital in India}

Change, Continuity and Conflict in Kerala

Shoba Arun

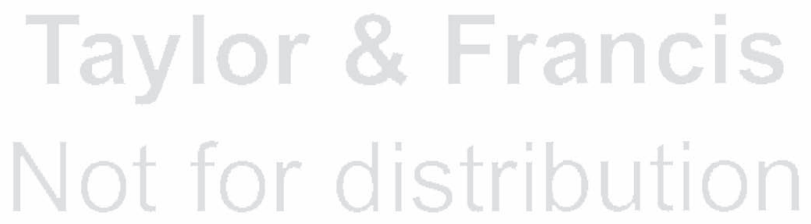




\title{
Development and Gender Capital in India
}

Change, Continuity and Conflict in Kerala

\author{
Shoba Arun
}

\footnotetext{
Routledge

- Taylor \& Francis Group

LONDON AND NEW YORK
} 
First published 2017

by Routledge

2 Park Square, Milton Park, Abingdon, Oxon OX14 4RN

and by Routledge

711 Third Avenue, New York, NY 10017

Routledge is an imprint of the Taylor \& Francis Group, an informa business

(C) 2017 Shoba Arun

The right of Shoba Arun to be identified as author of this work has been asserted by him/her/them in accordance with sections 77 and 78 of the Copyright, Designs and Patents Act 1988.

All rights reserved. No part of this book may be reprinted or reproduced or utilised in any form or by any electronic, mechanical, or other means, now known or hereafter invented, including photocopying and recording, or in any information storage or retrieval system, without permission in writing from the publishers.

Trademark notice: Product or corporate names may be trademarks or registered trademarks, and are used only for identification and explanation without intent to infringe.

British Library Cataloguing-in-Publication Data

A catalogue record for this book is available from the British Library

Library of Congress Cataloging-in-Publication Data [CIP data]

ISBN: 978-1-138-22196-3 (hbk)

ISBN: 978-1-315-40918-4 (ebk)

Typeset in Times New Roman

by Apex CoVantage, LLC 
Dedicated to

Mummy, Amma and Anantashree,

-the women in my life for instilling, shaping, and challenging the meaning and practices of everyday

feminism

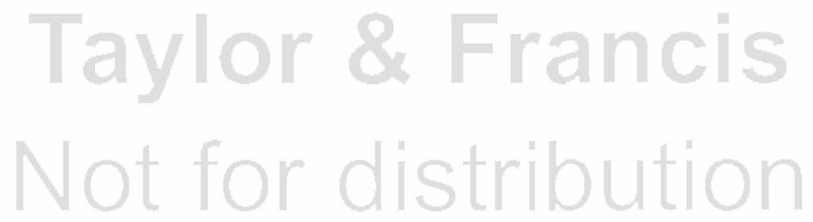




\section{Taylor \& Francis Not for distribution}




\section{Contents}

List of Tables

List of Abbreviations

viii

Acknowledgements

ix

xi

Glossary

xiii

1 Introduction

1

2 Gender and development: a Bourdieusian framework

3 Situating gender capital in Kerala

4 Matriliny and kinship: transforming gendered habitus in semi-rural livelihoods

$5 \quad$ ICT and gender capital@work

6 Migrating gendered capital

7 Gendered violence and victimisation: symbolic violence and complicity

8 Asset accumulation and Adivasis: limits to legitimate capital

9 Conclusion

Index 


\section{Tables}

2.1 Meshing of Theories: Pierre Bourdieu, Gender and Development Discourses

3.1 Social Indicators in Kerala and India 37

3.2 Work Participation Rates by Gender, 1983-2011 44

4.1 Interactive Effects of Gender, Habitus and Capital on Autonomy 69

5.1 Enablers and Disablers of Activation of Capital in IT Work 83

7.1 Perceptions on Causes of Domestic Violence against Women 121

7.2 Women's Perceptions on Causes of Sexual Violence against Women and Girls

8.1 Selected Indicators of Adivasis in Kerala and India $\quad 138$

8.2 Labour Force Participation Rates among STs 139

8.3 Household Asset Portfolio, by Type of Adivasi and Gender (\%) 145 


\title{
Abbreviations
}

\author{
ADSS Adivasi Dalit Samara Samithi \\ BJP Bharathiya Janata Party \\ BME Black and Minority Ethnic \\ BPL Below poverty line \\ BPM Business Process Management \\ BPO Business Process Outsourcing \\ BRIC Brazil, Russia, India and China \\ FGD Focus group discussion \\ FLFP Female labour force participation \\ GAD Gender and development \\ GDI Gender Development Index \\ GDP Gross Domestic Product \\ GNI Gross National Income \\ GSDP Gross State Domestic Product \\ HDI Human Development Index \\ ICT Information and communication technologies \\ IES Institute for Employment Studies \\ IGT Intergenerational Transmission \\ IMR Infant Mortality Rate \\ IRN Internationally Recruited Nurses \\ IT Information Technology \\ ITES Information Technology Enabled Services \\ IUML Indian Union Muslim League \\ LMS London Missionary Society \\ LSGI Local self-government institutions \\ MGLC Multi-grade learning centres \\ MPI Multidimensional Poverty Index \\ MVD Motor Vehicles Department \\ NCRB National Crime Records Bureau \\ NGO Non-Governmental Organisation \\ NHG Neighbourhood Households Groups \\ NHS National Health Service \\ NREGA National Rural Employment Guarantee Act
}


x Abbreviations

NSS National Sample Survey

PHC Primary Health Centre

PPP Purchasing power parity

RTO Regional Transport Office

SAP Structural Adjustment Policies

SC Scheduled Caste

SDG Sustainable Development Goals

SHG Self-help groups

SJVSV Sadhu Jana Vimochana Samyuktha Vedi

SNDP Sree Narayana Dharma Parpalana

ST Scheduled Tribe

UDF United Democratic Front

UNDP United Nations Development Programme

UPS Usual Principal Status

UPSS Usual Principal and Subsidiary Status

US United States

VAW Violence against women

WID Women in development

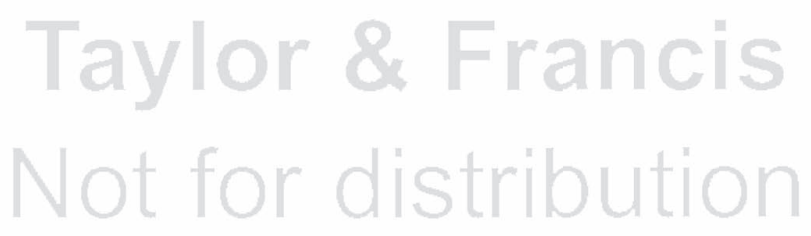




\section{Acknowledgements}

The task of writing acknowledgements for any piece of work is immensely difficult as it often includes the efforts of an endless list of people, experiences and encounters, hence rendering the process of marking recognition far from simple. The process of writing and producing a book is arduous, as it woven through an intricate web of immeasurable support and critical engagement with scholars, colleagues, students, family and friends. Even simple conversations with students, peers and strangers have supported my work in a critical way. Foremost, I am grateful to the Department of Sociology and the Research on Applied Social Sciences Research (RCASS), particularly Berthold Schoene and Steve Miles, at the Manchester Metropolitan University who provided me with critical support and environment to complete the book. I would like to record my sincere thanks to colleagues at Routledge for their confidence in this body of work and in my ability to finish this. I am indebted to scholars, policy makers and peers in the study of Kerala's society, through their work, interest and intellectual discussions in shaping this study, notably the (late) K.K Subrahmanian Michael Tharakan, Vani Borooah, Bina Agarwal, Thomas Isaac, Devika, Praveena Kodoth, K. Pushpangadan, Irudhaya Rajan, George Joseph and Leela Joseph J, Ravi Raman, TK Jose, Aruna Sundarajan, Sarada Muraleedharan, Wendy Olsen and the British Sociological Association (BSA)'s Bourdieu Study Group. I have obtained funding from The Nuffield Foundation for some part of the research, and assistance from various institutions in Kerala such as the Centre for Development Studies, Kudumbashree Mission, Planet Kerala, Shreyas (Wayanad) and SAKHI, Thiruvananthapuram, and am grateful for their support.

I am indebted to those who have read and commented on all or parts of this manuscript, and to encouraging colleagues, scholars and indulgent friends- Saskia Sassen, David Hulme, Kunal Sen, Debra Howcroft, Helen Richardson, Julia Rouse, Richard Heeks, Paul Kennedy, Leslie Sklair, Thankom Arun, Samuel Annim, Lord Beekhu Parekh, Burjor Avari, Susie Jacobs, Kathryn Chadwick, Scott Poynting, Bridget Byrne, Navtej Purewal, Vandana Desai, Savita Bailur, Caroline Moser, Sharon Morgan. Emily Goodier and Colin Jones provided much help with research and editorial assistance, and I would like to thank them.

I am forever grateful to the women of Kerala particularly those who were part of my research, whose lives and experiences have brought life to this work, and 


\section{xii Acknowledgements}

made me welcome in different phases of the research, motivating me through their struggles for identity and dignity.

Of course it is customary, but impossible to express or measure gratitude to the close network of family and friends, from whom I draw support and encouragement and who have sustained me at a very personal level and made allowances for my angst and frustration- notably my dear husband and friend, Arun. My daughter, Anantashree has bestowed me with the meaning and meaningfulness of pursuing my interest on gender relations.

The shortcomings are, of course mine alone.

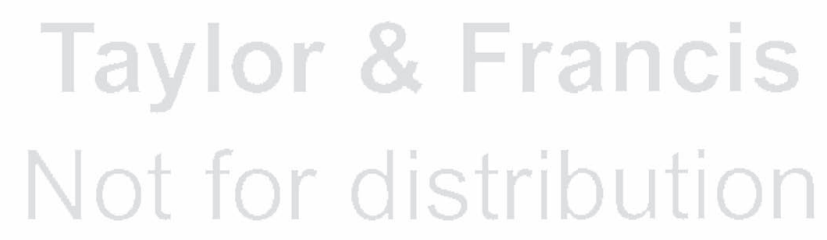




\section{Glossary}

Adivasi Indigenous communities of India known as Scheduled Tribes (STs)

Adiya Tribal group in Kerala

Anandaraven Nephews of maternal uncles in Nair households

Ayalkootam Neighbourhood self-help groups under Kudumbashree

Ayurveda Traditional system of medicine practiced in Kerala

Beti Bacho Save the girl child scheme of the central Indian government

Beti Padho Educate the girl child scheme of the central Indian government

Bharatheeya Relating to India

Chaturvarna Four-system classification of caste

Chengara Adivasi land struggle in the region of Chengara in Pathanamthitta

District, which started in 2007

Chitty Informal savings institutions

Coir Coconut husk

E-seva Electronic payment system for motor drivers

Ezhava Lower caste group in Kerala, originally comprising toddy tappers and workers.

Grihalakshmi Notion of domestic ideals of Indian housewife, griha - house and Lakshmi denotes goddess of wealth

Grihasta Housewife

Irula Adivasi group, mainly from Attapady region in Palakkad

Izzat Honour of family and community

Janmi Landlord

Jansree Women's self help group initiated by the UDF government

Kandam Rice wetland

Kattunaikkar Adivasi group that is mostly forest based

Krishi bhavan State farm office

Kshathriya Upper caste warrior group

Kudivaruppu Cottage processing of cashew

Kudumbashree Anti-poverty programme of the Kerala state government, targeting women from low-income households

Kumkum Saffron flower used for cosmetic purposes

Malayalee Member of ethnolinguistic group from Kerala

Manusmrithi Ancient text written by Manu 
xiv Glossary

Marumakkathayam Matrilineal system of descent

Mootha chetathy Eldest daughter-in-law

Moplahs Muslims from Malabar region

Muthanga Adivasi land struggle in Muthanga region in 2001

Nair Upper caste of Kerala

Naramada Bachao

Andolan Save Narmada campaign

Noolukettu Child-naming ceremony

Onam Harvest festival of Kerala during mid August to September

Panchayat Lowest administration unit as part of decentralisation

Paniya Adivasis people who are mainly landless labourers

Parambu Homestead land

Patta Official land ownership titles

Pembilai Orumai Female plantation labourers movement in Munnar in 2015

Sambhandam Conjugal relations in Nair families

Sircar Government in pre-colonial India

Taivazhi Mothers's lineage among Nairs

Tharavad Ancestral family home of Nairs

Theeyas Lower caste group from Malabar

Urali Adivasis group in Wayanad

Vishu New Year festival of Kerala based on the lunar calendar

₹ Denotation for Indian currency (Rupee, formerly denoted as Rs.)

$£ 1=₹ 85$ Approximately (January 2017)

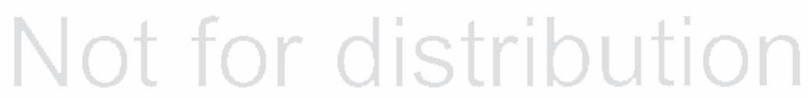




\section{Introduction}

The status of women as signifiers of human development has been examined much in feminist and development debates. Drawing on Karve's (1965) observation that women in south India enjoy more social status than women in northern India, Dyson and Moore's study (1983) highlights a positive relationship between female autonomy and demographic regimes related to social and health indicators and kinship structures. This thesis of the higher status of the south Indian woman than the north has been well cited throughout the Indian state of Kerala, receiving much attention in development debates (e.g. Dreze and Sen, 1996; Heller, 2001; Ravi Raman, 2010; Bhagwati and Panagariya, 2013). The state's history of social mobilisation, and as a vibrant civil society with well-developed human capital. has positioned Kerala as a unique model of development (Tornquist, 2000). This book explores how sociological, feminist and development critiques of mainstream social enquiry could be "appropriated" to explore the distinctive aspects of Kerala's society and economy. The central premise of this book concerns the anomie of the Kerala experience in both interpretation and the lived social reality of its women. It does so by engaging with a feminist-Bourdieusian framework to highlight the ambivalent role of gender capital within the hegemonic model of development. While the remarkable historic gains of women in Kerala are not without acknowledgement in this book, the study is motivated by the emerging evidence for contradictions and paradoxes on asymmetrical gender and power relations existing in both the private and public lives of the Kerala women. Many of the conceptual tools in gender and development discourses cannot fully grasp the complexity of gender relations as these are habitually constituted and reconstituted through intersecting social practices and social relations in diverse contexts. My own experience as a migrant Malayali girl (denoting membership of an ethno-linguistic group of Kerala) from a small hill town in south India has made me reflect on nuanced theoretical approaches to gender roles and relations. My Malayalee parents were often ridiculed for educating their girls (having no sons was another grave social violation), while my peers were often married soon after puberty. Simultaneous and perpetual valuations and devaluations of gender and social practices often posed both as structural and as agentic factors in my life choices. My own teaching in sociology departments across a range of UK higher education institutions has also influenced my thinking and ideas about 


\section{Introduction}

"sociological imagination" in theory and in praxis. As C. W. Mills (1959, p. 6) writes, 'The Sociological Imagination enables us to grasp history and biography and the relations between the two within society. That is its task and promise.' In many instances, such thinking relates to contemporary social concerns and social structures, including gender inequalities.

Kerala has undergone profound social development and demographic transition, bringing it much international and national attention. Whilst India ranked 130 among 188 countries in 2014 according to Human Development Report 2015 released by the United Nations Development Programme (UNDP), the country's rank was 135 according to the 2014 report.

India ranked 130 among 188 countries in the Human Development Report 2015, deeming it a medium development country, with a Human Development Index (HDI) score of 0.609 , Kerala scored a high of 0.79 , suggestive of commendable indicators of basic human development and quality of life through literacy, life expectancy and standard of living. Nevertheless in 2010, the BBC reported on Kerala's conundrum as a staggering economy, stating that it 'needs a new contract between the state and its people to move ahead and build upon its enviable gains' (The BBC online, 2010). Thus the development trajectory of the state has hinged much on its social and human development record amid lower economic growth; hence, Pierre Bourdieu's theory of social reproduction offers a paradigm of social analysis, particularly through his concept of symbolic relations which include economic relations and Max Weber's differential status, and going beyond Marxian notions of class hierarchy and economic power. His analysis of symbolic dimensions of social struggle and competition for capital helps explain forms of social reproduction and transformation. This analysis is highly relevant to the Kerala context, where material and symbolic power relations are at play, although discussions of material power predominate (see Fowler, 2000, p. 2).

Development and Gender Capital in India proposes the use of a Bourdeiusian framework, where gender is seen as part of the mutually constitutive relationship between field and habitus. The central tenet of Bourdieu's capital relates to his conceptualisation of symbolic and cultural power, which feminists have appropriated. As elaborated in Chapter 2, gender was never central to Bourdieu's analysis, though his work has continually influenced feminist theorisation and writings, particularly his social analysis that allows for interconnections of social divisions, such as class relations and culture. The Kerala model has drawn much from the higher levels of human, symbolic and cultural capital enjoyed by its women as a form of embodied gender or female capital. This model is manifest through its social policies, cultural practices and social change that have endowed women with higher levels of literacy and life expectancy, and also lower levels of fertility and maternal mortality rates. Thus the cultural and symbolic dimensions of female capital, termed here as "gender capital", have played a significant part in the Kerala model. For example, in the 1920s Queen Sethu Lakshmi Bayi of Travancore rewarded women who went to university with an invitation to tea at the palace. In addition, the royal family followed matrilineal practices whereby the maharajah's sister's sons inherited the throne (The Economist, 2013). Thus, 
education - a key element of Bourdieu's cultural capital - plays an important role in Kerala. In this respect, Bourdieu is similar to Durkheim's sociology as Fowler (2000, p. 12) writes, 'Durkheim has emphasised the significance of education for modernity', although human capital is then elaborated into other manifold forms of capital. Bourdieu's typology of capitals includes economic, cultural and social capital, where the last two forms of capital can be converted into the first form, akin to the Weberian concept of status and power. Through the use of the term gender capital (Huppatz, 2009; 2012), and unravelling forms of feminine, masculine and embodied capital, this book aims to move beyond the conventional framework of patriarchy that theorises forms of gender domination and relations. The notion of gender capital is particularly useful, as the Kerala woman is well noted for her female capital through notions of autonomy and has been instrumental in achieving the Kerala model of development through possessing higher levels of "human and cultural capital".

However, as the book sets out to examine, the mere possession of capital - for example, education - does not necessarily mean an individual can realise a social advantage from such a resource, as to do this they must be "effectively activated' (Lareau, 1989, p. 179), which relates to practices and interactions within social domains or fields. For Bourdieu (1984), the field is the social arena in which actors and their respective spheres of power compete for meaning and legitimacy; it is from this that habitus emerges. Thus, sites such as households, schools and workplaces are "fields" with structured spaces organised around specific capital or combinations of capital, where actors are involved in the "game" and "rules" as they stratigise and struggle over the unequal distribution of valued capitals, so they compete for meaning and legitimacy. The role of the family or the household and its impact on women's subordination, particularly within development debates, has been much discussed (e.g. Kabeer, 1994; Elson, 1995; Agarwal, 1997). The family occupies a central place in feminist theory as women's subordination has been intimately related to various forms of and practices within it - for example, women's sexuality and reproduction, control over property, the economics of domestic labour and state regulation of family life (see Walby, 1997). Fowler (2000) notes how, although Bourdieu failed to grasp the changing characteristics of patriarchy within different periods (notably that of capitalist modernity), Bourdieu's work does provide quality analytical tools such as "doxa" and the "illusio" of masculine domination (Bourdieu, 2001). Bourdieu's androcentric bias in his works has been well noted (see McCall, 1992; Laberge, 1995) through his patrilinear focus (see Silva, 2005; Huppatz, 2012) whereas gender is akin to a "secondary" principle (Bourdieu, 1984, p. 106) structuring the social space. However, Bourdieu recognises the strength of the structuring power of gender properties, as the volume and composition of capital is structured by gender properties within each social group. The following quote has been used repeatedly to show this ambivalent treatment of gender:

Sexual properties are as inseparable from class properties as the yellowness of a lemon is from its acidity: a class is defined in an essential respect by 


\section{Introduction}

the place and value it gives to the two sexes and to their socially constituted dispositions. This is why there are so many ways of realizing femininity as there are classes and class fractions, and the division of labour between the sexes takes quite different forms, both in practices and in representations, in the different social classes.

(Bourdieu, 1984, pp. 107-108)

This led McCall (1992) to advocate the use of constructed femininity and masculinity as indices of class (capital) structure, which would rectify inherent male bias and thus conceptualise gendered capital (see McCall, 1992; Laberge, 1995). Gender traits, often classified as masculine and feminine, may or may not stem from biological or sexual identities. For example, the Australian sociologist Raewyn Connell theorised gender relationships by exploring social structures and the conceptions and practices around masculinity. In particular, Gender and Power (1987) shows how interlinked structures produce particular "gender orders", or "regimes", through hegemonic masculinity. It highlighted how the division of three sets of structures - labour, power and cathexis - produce gender inequalities. Through this, gendered inequalities prevail, especially through gendered roles, for example through the gender division of labour, and power within the household. Similarly, masculinity pervades the public life as the labour market contains gendered hierarchies; political and decision-making positions similarly generally favour masculinity; and masculinity generally sets rules for sexual engagement and sexual behaviours, leading to gendered regimes within society. Such social constructions of forms of gender capital will be of prime concern in this book.

Bourdieu's $(1990 ; 2000)$ conceptualisation of social inequalities and their social reproduction is further explained through the concept of symbolic violence and its invisible nature, which facilitates domination in different forms that are embedded in everyday lives (Morgan and Björkert, 2006). For example, the prevalence and practice of dowry and inheritance in the Indian (or South Asian) context has implications for women's status and experience, including dowry-related violence. Such structures of domination persist through Bourdieu's symbolic violence - a violence that is 'censored, euphemized, that is, misrecognizable, recognized violence' (Bourdieu, 1990, p. 126). Feminist debates in South Asia often question trends in dowry practices, preference for sons compared to daughters, female infanticide and declining sex ratios which violate women's agency in wider social relations (see Sharma, 1980; Kishwar, 1999; Purewal, 2010). Thus, gendered capital pervades cultural and symbolic practices, which could be referred to as doxa, or shared practices that uphold forms of domination and hierarchy within a patriarchal system.

As Krais (2006) argues, Bourdieu's theoretical understanding of gender as a powerful principle of social differentiation opens up new analytical perspectives for feminist sociological theory whereby social practice allows space for resistance and change. For Bourdieu, the category "woman" is not a homogeneous, singular identity but is instead lived and intimately experienced 'as a form of subjectivity inhabited through other categories' (ibid., p. 166). Thus, Bourdieu's 
theory opens up the possibility of social change and transformation by representing gender relations as socially constructed - an analysis concurrent with that of numerous socialist and materialist feminists (Moi, 1990). Furthermore, by integrating gender distinction into the concept of cultural capital (and habitus), Huppatz (2009) makes an important and useful distinction between "female" and "feminine" capital to understand processes involved in procuring classed and gendered workers and occupations. To gain a sociological understanding of the complex interactions between structure and agency through mobilities and new (and multiple) domains, habitus is a handy tool when seen as "systems of durable, transposable dispositions, structured structures predisposed to function as structuring structures" (Bourdieu, 1990, p. 53). However, the concept of habitus is not rigid or stable; for example, Silva (2016) maps Bourdieu's changing presentations of the notion of habitus from being unified to later fragmentation. Thus, while this book focuses on relations between social practices generated through habitus, it does so having adopted a more pliable notion of habitus to unravel both its structured nature and its restructuring simultaneously.

\begin{abstract}
Aims
This books adopts a Bourdieusian lens on analytical and theoretical foci on gender, feminism and development, to unravel the gendered nature of Kerala's social context. It investigates the interactions between social thought and ideas, practices and experiences, through several interrelated themes. First, it shows how global development and societal contexts are gendered spheres where men and women are positioned differently and participate in society and the economy differently; they do this through capitals/resources either available to them or legitimised through gendered processes and structures. The second theme delves into structural constraints and women's agency. Its particular focus is how these are enacted through dominant patriarchal norms in private and public domains through gendered frames of domesticity and sexuality that value gender capital differently and shape (or change) their habitus through reproducing or rupturing global processes. The final theme recognises differences among women via an intersectional approach whereby issues of class, caste and ethnicity intersect with gender. Such differences manifest themselves through several inequalities that highlight multiple processes of symbolic domination and misrecognition. All three of these issues together show how forces of globalisation are partially embedded in power structures, including the nation state, but are done so in different ways that bring both opportunities and challenges for men and women, re-creating and reinforcing power relations that reflect tropes of agency, rhetoric and victimhood.
\end{abstract}

\title{
Development and change through global transformations
}

Boserup's (1970) seminal work sparked an information revolution on issues concerning women in society regarding shifts in wider policy and academic thinking about development and gender issues. Subsequently, 1976-1985 (declared 


\section{Introduction}

by the UN as the decade for women) was ensued by approaches to conceptualise women's role in development processes. Many women in development discourses (e.g. the WID) reflect 1980s modernisation theories. Based on Western feminism, these theories focused on equal participation in work and education, reproductive rights and sexual freedom, whilst the gender and development (GAD) discourses focussed more on the social relations between men and women. Despite manifold approaches to address gender domination, issues of differences between groups of women remain a huge challenge in social analysis, as issues of patriarchy, racism capitalism and globalisation often blur social divisions between women. Challenging the hegemony of white Western feminism, Bulbeck (1998) shows that such ethnocentric feminism means little to the women of rural India, young Thai girls in the sex industry in Bangkok or Filipino maids working for wealthy women in Hong Kong; she does so by examining the lived experiences of "women of colour" (ibid.). The significance of interconnected systems of inequality was brought about by Walby (2007), who also discussed intersectionality. The author shows how women often experience multiple disadvantages because of intersecting factors such as class and ethnicity. Such "cumulative effects" of multiplicity and the intersection of mutually reinforcing factors (e.g. class, ethnicity, gender, disability, age and geography) as well as the systems and social relations of oppression (e.g. racism, sexism, classism and ableism) affect individuals (Crenshaw, 1991; McCall, 2005; Hancock, 2007; Walby, 2007). Thus, discourses and practices that stress difference, especially contexualizing difference between women is relevant in Kerala, where women have plural identities - evident, for example, with class, caste, ethnicity (e.g. Adivasi) and sexuality. Adivasi marginalisation within the Kerala model, often cited as a paradox within a paradox (Chandran, 2012; Steur, 2014), raises questions for Kerala Adivasi women, where the cumulative effects of gender, ethnicity and class are played out through their "difference" and "oppression". Thus the intersecting role of gender, class and spaces then become significant in exploring connections between habitus and fields (Silva, 2016).

The forces associated with globalisation, neoliberalism and economic crises here concern economic integration, technological diffusion and increased mobilities which all have implications for gender equality. For example, the World Development Report (World Development Report, 2012) argues that globalisation has the potential for greater gender equality through increased access to economic opportunities, stronger incentives for action, and shifting gender norms and roles. Yet there is a gendered dimension of globalisation in expanding capitalist relations of production by restructuring national, local, regional and international actors. The well-known Dutch - American sociologist Saskia Sassen (2007) writes about how contemporary global markets for capital, global trade and the internationalisation of production have altered the role of nation states. In particular, a key tenet of global neo-liberal ideologies has been the rise of ICT (information and communication technologies), which has transformed those work practices largely constructed around the frames of gendered discourses, institutions and interactions. In the Indian context, the market-driven growth in ICT employment opportunities for women has brought women into this sector and created new 
status relations based on class and, in the burgeoning middle classes, reduced concerns about caste and kinship relations (D’Mello, 2009). Studies on the ICT industry nevertheless show the masculine culture and distinct gender division within it (Wajcman, 2004; Howcroft and Richardson, 2009; Basi, 2009) mean that women are required to "fit in" so, in general, the impact of ICTs may reify broader gender inequalities, ideologies and insecurities. Consequently, overall gains from women working in ICT sectors are questionable (Howcroft and Richardson, 2009). Bebbington (2007) shows how numerous feminist authors (see Molyneux, 2002) have questioned the gender-blind assumptions that underpin dominant neoliberal development ideologies, particularly through enhancing social capital of poor women. Examples are notions of social capital as "the capital of the poor" but also that of the "poor women".

In many ways, the contradictions and complexities of women's lives have increased, altering the ways the redefined relations of the state, the market and civil society are gendered, particularly in a global context (Rai, 2002). The concept of "gender capital" - as both a discursive space and an analytical category helps unravel discourses on agency and social structures, power relations and resource allocation, and it allows us to discern the shaping of practices and institutions through such gendered analysis. This is done through examining (1) the transformation of agrarian and semi rural livelihoods; (2) the impact of neo-liberal discourses and work practices through new technology enables work practices; (3) the transnational feminisation of migration; (4) discourses on violence and power relations; (5) and the gendered "other"- citizenship and exclusion through an intersectionality perspective. The design of the research context is itself complex: one the one hand, Kerala is romanticised in a utopian sense with its citizenry, particularly women, being free of bonded social divisions and uplifted through educational and physical well-being; on the other, its realism is stark, overpowering and contradictory. Yet these two usually opposed aspects are often indistinguishably fused into each other as a product of social anomies, absorbed by human experiences. Although at times it may reflect a myth of social harmony, at others it is also an ironical exposure of myths behind the powerful assertions of societal progress.

\section{Organisation of the study}

Chapter 2 maps out key concepts, debates and methodological issues in and for this work, and it does so by integrating theoretical and empirical perspectives from Bourdieusian, feminist, development and gender studies - especially those relevant to developing contexts (primarily South Asia and India). It shows how the concept of habitus and the value of capitals depend on the field (context) of practice; it also explores how each agent's habitus is conceptualised through development feminist habitus and is heavily structured through its relational position within wider relationships and structures of social difference: nation, class, caste (in India), gender, ethnicity, and so on.

Chapter 3 situates the Kerala model of development and emerging issues in terms of its the gender record which has come under scrutiny(Saradamoni,1999; 


\section{Introduction}

Kodoth and Eapen, 2005;Mitra and Singh, 2007; Mukhopadhyay, 2007; Devika, 2009), bringing debates and even challenges to the Kerala model (see Bhagwati and Panagariya, 2013). One cannot deny that the Kerala woman is an important resource in the Kerala model of development, but she does exhibit a markedly gendered relationship in terms of her identity, economic and political participation, and representation. This is where a "zoom" on the importance of both the agency and the structural issues of the Kerala woman through a Bourdieusian analysis brings to the fore women's experience, struggles and engagement with the state. This can be done by viewing women "as capital-accumulating subjects rather than capital-bearing objects in social space' (Lovell, 2000, p. 12), which converts forms of capital.

Chapter 4 explores how agrarian transformation has influenced the gender relations, spatialities and identities of women in semi-rural contexts. It draws observations on the nature of gendered habitus, extent of bargaining power and autonomy, focussing on aspects of changing forms of matriliny and kinship practices within the semi-rural Kerala context. This engenders understanding of Bourdieu's symbolic order of gender, where a gendered habitus emerges as an embodied form through the social construction of gendered practices, norms and dispositions. It is organised around themes of power, difference and equality, work and paid employment, and the distribution of assets and resources, where the restructuring of the habitus also occurs through changing social practices and wider economic change.

Chapter 5 shows information and communications technology (ICT)-related work spheres as sites of change, control and resistance, and constitutive of emotional and embodied dimensions of women's lived experiences by engaging with ICT work and its effects. Through a Bourdieusian analysis, I reconceptualise ICT work practices as a powerful emotionally embedded work practice that structures social behaviours yet simultaneously inflects gendered identities. The different and unequal experiences of different groups of women in varied work environments are significant in an intersectional approach, by incorporating class (and caste status) relations. As other studies have shown, simply gaining access to the knowledge worksphere through paid work does not lead to women's empowerment (Basi, 2009). The use of habitus and capitals in the realm of knowledge work facilitates understandings of processes that help or constrain the activation of different forms of capital (Reay, 2004; Gillies, 2006). Here, the complexity of the fields and how the fields overlap both undermine and reinforce each other. This opens up debates on the struggles over the value of various forms of capital and their convertibility into symbolic capital, though as Bourdieu observes, the same practices may receive opposite meanings and values in different fields.

With a long history of labour migration, juxtaposed alongside a good record of human capital, particularly for women, Kerala is an illustrative example where the dynamics of migration operate in a local-global context, engendering the formation of global gendered capital. The increasing phenomenon of feminisation of migration from Kerala into the Western care and health sectors (Arun, 2010; Walton-Roberts, 2012) has been well noted. This is indeed an outcome of the 
Kerala model of development, manifested as embodied female capital because of higher levels of female literacy, aspiration for social and inter-generational mobility, and gender empowerment. More broadly, though, flows of migration and the interplay of forces of neoliberalism as manifested through increasing work opportunities in the context of globalisation has seen increased movements of all groups, including women, in Asia (see ADB-ILO, 2011). As Savage, Bagnall and Longhurst (2005) show, distinct social groups that are intersected by gender, race and class can impose their habitus in the local arena through globalisation forces. Thus, with increasing economic migration and greater interplay of economic and cultural capital, gender, along with other social divisions, contributes to these new cultural forms, forming global and transnational formations. Gendered migration evidently intersects with different historical trajectories of migrations and with persistent social constructions of care and body work, where the habitus is tested while striving to "fit in" the field and transform both migrant habitus and gendered capital.

Chapter 7 examines how Bourdieu's concept of symbolic violence is enacted on at different levels: at the micro-level in women's everyday lived experiences in the private sphere through complicity and consent but also more broadly in terms of how macro-politics and institutional complicity reify physical and symbolic violence against women and girls, leading to gendered justice. The chapter will show how the matrix of patriarchy, power and social relations within the Kerala context tie in with Bourdieu's concepts of misrecognition and symbolic violence. Violence is indeed a gendered subject: when issues of sexual and domestic violence are discussed, women are often seen as passive victims of male violence. Kerala is no different, but more worryingly - given the rhetoric of the capable and empowered Kerala woman - victims of sexual violence, particularly young girls, are caught in discourses of feminism, violence and human rights yet struggle for justice because of structures, mechanisms and social norms. The ways sexual violence by men towards women is normalised is evinced through feminist research on "fear of crime" (Stanko, 1985, p. 1990), where both on an individual and institutional basis men's dominance creates the context for sexual violence. Hence, normalisations of gendered fear, practices and norms lead to complicity in different forms of control and violence in women's everyday lives, pervading both the public and private sphere.

The concepts of symbolic violence and misrecognition is further explored in Chapter 8 through revisiting the thesis of feminisation of poverty (Jackson 1998; Chant, 2003) among the indigenous communities or Adivasis in Kerala. Discourses on inequality such as poverty debates, as well as sociological explorations on racial and ethnic inequalities, have too often focussed resource inequalities and discrimination (see Rex, 1970; Miles, 1982) in relation to economic capitalism. These approaches often promote deficit views of minorities in different contexts. In many ways, although Bourdieu's work on capital has not addressed race issues, the concepts of habitus and cultural capital have been used to bring out the interactions of class, racial and ethnic disadvantages (Rollock, 2012; Wallace, 2016). A social analysis becomes meaningful when it takes into account the 
sum of capital and resources possessed rather than what they lack (Bebbington, 2007 ) in relation to conventional notions of capital or resources. Chapter 8 argues that the livelihood choices and practices of Adivasis are often not legitimised, and have limited symbolic recognition accorded in the mainstream Kerala model as well as through national development practices. Such processes of misrecognition and acts of symbolic violence are a result of asymmetrical gender and power relations ingrained through patterns of (mis)representation, and they are embedded within practices, discourses and subjectivities.

\section{Conclusion}

The Kerala woman is indeed posed here as an enigma - one without her own identity, and sometimes without dignity, as she is often presented in relation to her men or in comparison with women from other geographical contexts. Culturally and historically, she is drawn on as a resource, with increased capabilities (as gender capital) for being instrumental in influencing social development, but yet she has been able to "activate" her own gender capital within limits and constraints at both the individual and collective levels. It is indeed an anomie when the wellcited Malayalee woman in many instances is caught in discourses of feminism, development and human rights but victimised, sexualised and domesticised within the wider context of material, economic and political forces. This is also espoused in the everyday experiences of social and cultural practices, such as dowry, marriage, and economic and social patriarchy, which are all enmeshed within localglobal contexts. All this raises issues concerning power and social relations in a range of contexts, both in the local and in the global sphere. In this wider context, gender issues are more relevant as new questions emerge about social relations, at several levels, that have not been addressed in existing approaches and frameworks within social research. To date, discourses of empowerment have been used much to analyze women's status as an analytical construct; if applied to the Kerala context, this may be subject to contradictions and contestations. This is indeed mystifying, as the women of Kerala have long been upheld as possessing higher levels of empowerment through their practices within the matrilineal system, as well as higher education and health indicators, yet it seems that the rhetoric of the Kerala woman seems to be socially constructed. This book maps such gender issues within the constructs of power relations and work practices in a range of contexts; it does so with a focus on the accumulation of capital, changing habitus and representations, and how gender is implicated in power relations.

\section{References}

ADB-ILO. (2011). 'Women and labour markets in Asia: Rebalancing for gender equality.' Asian Development Bank and the International Labour Organisation. [Accessed on 18 January 2017] Available at: www.adb.org/publications/women-and-labour-marketsasia-rebalancing-gender-equality.

Agarwal, B. (1997). 'Bargaining and gender relations: Within and beyond the household.' Feminist Economics, 3(1), pp. 1-51. 
Arun, S. (2010). 'Caring cosmopolitans and global migration: plus ça change?' In: Ravi Raman, K. (ed.), Development, Democracy and the State: Critiquing the Kerala Model of Development, pp. 204-218. London: Routledge.

Basi, J. T. (2009). Women, Identity, and India's Call Centre Industry. London and New York: Routledge.

The BBC. (2010). 'Conundrum of Kerala's struggling economy.' Available at: <http:// news.bbc.co.uk/1/hi/world/south_asia/8546952.stm>.

Bebbington, A. (2007). 'Social capital and development studies II: Can Bourdieu travel to policy? Progress in Development Studies, 7(2), pp. 155-162.

Bhagwati, J. and Panagariya, A. (2013). India's Tryst With Destiny: Debunking Myths that Undermine Progress and Addressing New Challenges. India: Harper Collins.

Boserup, E. (1970). Women's Role in Development. London: Earthscan.

Bourdieu, P. (1984 [1979]). Distinction: A Social Critique of the Judgement of Taste. London: Routledge.

Bourdieu, P. (1990). In Other Words: Essays Towards a Reflexive Sociology. Stanford: Stanford University Press.

Bourdieu, P. (2000). Pierre Bourdieu. London: SAGE Publications.

Bourdieu, P. (2001). Masculine Domination (Trans. R. Nice). Cambridge: Polity Press.

Bulbeck, C. (1998). Re-orienting Western Feminisms: Women's Diversity in a Postcolonial World. Cambridge: Cambridge University Press.

Chandran, D. (2012). 'A paradox within a paradox: Emerging signs of change in the unappealing tribal scenario in Kerala, India.' Developing Country Studies, 2(6), pp. 1-11.

Chant, S. (2003). 'Female household headship and the feminisation of poverty: Facts, fictions and forward strategies.' New Working Paper Series. Issue 9: May. ISSN: 1470-8515. Gender Institute, London School of Economics and Political Science, London, UK. (Unpublished). [Accessed on 21 August 2016] Available at: $<$ http://eprints.lse. ac.uk/574/?

Connell, R. (1987). Gender and Power: Society, the Person and Sexual Politics. Cambridge: Polity Press.

Crenshaw, K. (1991). 'Mapping the margins: Intersectionality, identity politics, and violence against women of color.' Stanford Law Review, 43(6), pp. 1241-1299.

D'Mello, M. (2010). 'Are you married? Exploring gender in a global workplace in India.' In: Howcroft, D. and Richardson, H. (eds.), Work and Life in the Global Economy: A Gendered Analysis of Service Work, pp. 52-77. London: Palgrave Macmillan.

Devika, J. (2009). 'Bodies gone awry: The abjection of sexuality in development discourse in contemporary Kerala.' Indian Journal of Gender Studies, 16(1), pp. 21-46. doi: 10.1177/097152150801600102.

Dyson, T. and Moore, M. (1983). 'On kinship structure, female autonomy, and demographic behaviour in India.' Population and Development Review, 9(1), pp. 35-60.

The Economist. (2013). 'Women in Kerala: Mixed fortunes for the daughters of Travancore.' Available at: www.economist.com/blogs/banyan/2013/03/women-kerala.

Elson, D. (1995). Male Bias in the Development Process. Manchester: Manchester University Press.

Fowler, B. (ed.). (2000) Reading Bourdieu on Society and Culture. Oxford and Malden, MA: Blackwell Publishers/The Sociological Review.

Gillies, V. (2006). 'Working class mothers and school life: Exploring the role of emotional capital.' Gender and Education, 18(3), pp. 281-293.

Hancock, A. (2007). 'When multiplication doesn't equal quick addition: Examining intersectionaility as a research paradigm.' Perspectives on Politics, 5(1), pp. 63-79. 


\section{Introduction}

Heller, P. (2001). 'Moving the state: The politics of democratic decentralization in Kerala, South Africa, and Porto Alegre.' Politics and Society, 29(1), pp. 131-163.

Howcroft, D. and Richardson, H. (eds.). (2009). Work and Life in the Global Economy: A Gendered Analysis of Service Work. London: Palgrave Macmillan.

Huppatz, K. (2009). 'Reworking Bourdieu's capital: Feminine and female capitals in the field of paid caring work.' Sociology, 43(1), pp. 45-66.

Huppatz, K. (2012). Gender Capital at Work: Intersections of Femininity, Masculinity, Class and Occupation. London: Palgrave Macmillan.

Jackson, C. (1998). 'Rescuing gender from the poverty trap.' In: Jackson, C. and Pearson, R. (eds.), Feminist Visions of Development: Gender Analysis and Policy, pp. 39-64. New York: Routledge.

Kabeer, N. (1994). Reversed Realities: Gender Hierarchies in Development Thought. London: Verso Books.

Karve, I. (1965). Kinship Organisation in India. Bombay: Asia Publishing House.

Kishwar, M. (1999). Off the Beaten Track: Rethinking Gender Justice for Indian Women. New Delhi: Oxford University Press.

Kodoth, P. and Eapen, M. (2005). 'Looking beyond gender parity: Gender inequities of some dimensions of well-being in Kerala.' Economic and Political Weekly, Xi(30), pp. $3278-3286$.

Krais, B. (2006). 'Gender, sociological theory and Bourdieu's sociology of practice.' Theory, Culture and Society, 23(6), pp. 119-134.

Laberge, S. (1995). 'Toward an integration of gender into Bourdieu's concept of cultural capital.' Sociology of Sport Journal, 12, pp. 132-146.

Lareau, A. (1989). Home Advantage: Social Class and Parental Involvement in Elementary Education. London: Falmer.

Lovell, T. (2000). 'Thinking feminism with and against Bourdieu.' Feminist theory, 1(1), pp. 11-32.

McCall, L. (1992). 'Does gender fit? Bourdieu, feminism, and conceptions of social order.' Theory and Society, 21(6), pp. 837-867.

McCall, L. (2005). 'The complexity of intersectionality.' Signs, 30(3), pp. 1771-1802.

Miles, R. (1982). Racism and Migrant Labour. London: Routledge and Kegan Paul.

Mills, C. W. (1959). The Sociological Imagination. New York: Oxford University Press.

Mitra, A. and Singh, P. (2007) 'Human capital attainment and gender empowerment: The Kerala paradox'. Social Science Quarterly, 88(5), pp. 1227-1242.

Moi, T. (1990). 'Feminism and postmodernism: Recent feminist criticism in the United States.' In: Lovell, T. (ed.), British Feminist Thought: A Reader, pp. 367-376. Oxford: Blackwell.

Molyneux, M. (2002). 'Gender and the silences of social capital: Lessons from Latin America.' Development and Change, 33(2), pp. 167-188.

Morgan, K. and Björkert, S. T. (2006). 'I'd rather you'd lay me on the floor and start kicking me: Understanding symbolic violence in everyday life.' Women's Studies International Forum, 29(5), pp. 441-452.

Mukhopadhyay, S. (2007). The Enigma of the Kerala Woman: A Failed Promise of Literacy. New Delhi: Social Science Press.

Purewal, N. K. (2010). Son Preference: Sex Selection, Gender and Culture in South Asia. Oxford and New York: Berg.

Ravi Raman, K. (ed.). (2012). Development, Democracy and the State: Critiquing the Kerala Model of Development. London: Routledge.

Rai, S. M. (2002). Gender and the Political Economy of Development: From Nationalism to Globalization. Cambridge: Polity Press. 
Reay, D. (2004). 'It's all becoming a habitus: Beyond the habitual use of habitus in educational research.' British Journal of Sociology of Education, 25(4), pp. 431-444.

Rex, J. (1970). Race Relations in Sociological Theory. London: Weidenfeld and Nicolson.

Rollock, N. (2012). 'The invisibility of race: Intersectional reflections on the liminal space of alterity.' Race Ethnicity and Education, 15(1), pp. 65-84.

Saradamoni, K. (1999). Matriliny Transformed: Family, Law and Ideology in Twentieth Century Travancore. New Delhi: SAGE Publications.

Sassen, S. (2007). A Sociology of Globalization: Contemporary Societies Series. New York: Norton.

Savage, M., Bagnall, G. and Longhurst, B. (2005). Globalization and Belonging. London: SAGE Publications.

Sen, A. and Dreze, J. (1996). India: Economic Development and Social Opportunity. New York: Oxford University Press.

Sharma, U. (1980). Women, Work and Property in North West India. London: Tavistock Publications.

Silva, E. B. (2005). 'Gender, home and family in cultural capital theory.' The British Journal of Sociology, 56(1), pp. 83-103.

Silva, E. B. 2016. Unity and fragmentation of the habitus. The Sociological Review, 64(1), pp. 166-183.

Stanko, E. A. (1985). Intimate Intrusions: Women's Experiences of Male Violence. London: Routledge.

Steur, L. (2014). 'An "expanded" class perspective: Bringing capitalism down to earth in the changing political lives of Adivasi workers in Kerala.' Modern Asian Studies, 48(5), pp. 1334-1357.

Tornquist, O. (2000). 'The new popular politics of development: Kerala's experience.' In: Parayil, G. (ed.), The Development Experience: Reflections on Sustainability and Replicability, pp. 116-138. London: Zed Books.

Wajcman, J. (2004). Technofeminism. Cambridge: Polity Press.

Walby, S. (1997). Gender Transformations. London: Routledge.

Walby, S. (2007). 'Complexity theory, systems theory, and multiple intersecting social inequalities.' Philosophy of the Social Sciences, 37(4), pp. 449-470.

Wallace D. O. (2016). 'Re-interpreting Bourdieu, belonging and black identities: Exploring "black" cultural capital among black Caribbean youth in London.' In: Thatcher, J., Ingram, N., Burke, C. and Abrahams, J. (eds.), Bourdieu: The Next Generation - the Development of Bourdieu's Intellectual Heritage in Contemporary UK Sociology, pp. 37-54. Abingdon and New York: Routledge.

Walton-Roberts, M. (2012). 'Contextualizing the global nursing care chain: International migration and the status of nursing in Kerala, India.' Global Networks, 12(2), pp. $175-194$.

World Development Report. (2012). Globalization's Impact on Gender Equality: What's Happened and What's Needed. Washington, DC: World Bank. [Accessed on 30 August 2016] Available at: <http://siteresources.worldbank.org/INTWDR2012/Resources/777 8105-1299699968583/7786210-1315936222006/chapter-6.pdf> 


\title{
2 Gender and development
}

\author{
A Bourdieusian framework
}

\section{Introduction}

Although gender was never central to Bourdieu's analyses, his work continually influences feminist theorisation and writings, rekindling nuanced workings of gender and its interconnections with class and culture. His conceptualisation of social theory and class through the three building blocks of habitus, field and capital represents the trinity of how society reproduces itself (McKnight and Chandler, 2012). Bourdieu's sociological framework centres on this trinity and goes beyond economistic explanations of class to address the binaries of structure and agency, and it has been widely used across many disciplines, including education, management and women's studies. His early works did not address gender, but his later work Masculine Domination (2001) explored the subject of its title and, alongside his previous works, has been used extensively by feminist academics to theorise and research the extent to which these concepts can be applied to feminist writing. This chapter first briefly explains the trinity of Bourdieu's framework and its usefulness for theorisations on feminist discourses. It does so by constructing a "development feminist habitus" (drawing on McCall, 1992, p. 852) and a "gender capital" framework (see Huppatz, 2009) to inform empirical research within the field of gender and development discourses.

\section{The trinity of habitus, field and capital}

Bourdieu's contribution to sociology provides a broad understanding of how social actors operate within relations of difference, power and domination. For him, class involves multiple power relations with many intersecting dimensions, which are deciphered through schemas of capital. Moving away from linear and quantitative signifiers of economic capital such as occupation, income etc, these forms of capital comprise both quantitative and qualitative variables such as skills, lifestyle choices, art preferences, clothes, education and tastes (Reay, 1998, p. 24). Furthermore, Bourdieu's unique concept of habitus is key to his analysis of social identity as it theorises a self that is socially produced and constitutive of social relations, which for him is a "socialised subjectivity" (Bourdieu and Wacquant, 2002, p. 126). In simple terms, Bourdieu (1984) writes about the relationship of 
key aspects of his theory, claiming that one's practice interlocked with one's habitus, relative capital and with the field in which one operates. These interlocking themes constitute his relational framework:

$$
[(\text { habitus })(\text { capital) }]+\text { field }=\text { practice }
$$

(Bourdieu, 1984, p. 101)

For Bourdieu, habitus is socially constructed and mediates between the binaries of structure and agency. Habitus is thus acquired unconsciously through people's lived experience in a certain position within the social world. It also takes on the properties of the "conditions of existence" whereby

the body does not represent what it performs, it does not memorise the past, it enacts the past, bringing it back to life. What is "learned by the body" is not something one has, like knowledge that can be brandished, but something that one is.

(Bourdieu, 1990, p. 73)

In this way, individuals are predisposed to act in particular ways because of the habitus ${ }^{1}$ acquired through experience, and this acts as an "internalized set of tacit rules governing strategies and practices in the field" (Moi, 1990, p. 271). The household and the family are therefore key sites in forming habitus, though such structures of internationalisation have varying effects as habitus may generate different outcomes for different groups (Lawler, 2004, p. 112).

The second aspect of Bourdieu's theory of social reproduction relates to capital. Every individual or agent has a portfolio of capital that can present itself in three main forms: economic (money and assets), social (relationships and networks) and cultural (Crossley, 2008). Bourdieu discusses capitals in relation to the structure of the economic context and its materiality (Moi, 1990; Skeggs, 1997) but moves beyond the Marxist concept of economic capital and material exchanges to other forms of capital (Bourdieu, 1986; Swartz, 1997). Primarily, these capitals take three forms: embodied ("in the form of long-lasting dispositions of the mind and body" Bourdieu, 1997, p. 47); the objectified (cultural goods, such as books, pictures); and the institutionalised (academic credentials) (Bourdieu, 1986,p. 243). "Social capital" refers to 'the connections and networks an agent may call on in their effort to achieve a specified goal' (Crossley, 2001, p. 97), while "symbolic capital" signifies "the form the different types of capital take once they are perceived and recognised as legitimate' (Skeggs, 1997, p. 8).

What, then, does this typology of capital mean for feminism and gender studies? In the main, it relates to how feminist theory reclaimed the significance of social class. Studies in the late 1990s lamented the lack of discussions on class within key academic disciplines such as sociology (Reay, 1998; Skeggs, 1997), as this approach was deemed a "cultural dinosaur" (Skeggs, 1997, p. 7). Feminist theorists wrote how discussions drawn from Bourdieu restore materiality to feminism; in these, materiality, symbolisation, representation, discourse and text 
facilitate analyses of how inequalities are produced, and feminist theory reclaims social class (Adkins, 2004). As not all individuals have access to capitals that are equally valued in particular fields, feminist discussions show how, through different social processes, outcomes are valued, legitimised and reproduced. For example, as Bourdieu claims, it is the values, tastes and behaviours of the middle classes that are the most valued and legitimated (Lawler, 2005), as effective activation of capital is required, which also requires "recognition" (Lareau, 1989, p. 179).

Such unequal practices and interactions mark distinctions among groups and establish boundaries and hierarchies, bringing forth discussions on the third cornerstone of the trinity - the "field". For Bourdieu (1984), the field is the social domain in which actors and their respective spheres of power compete for meaning and legitimacy. As Swartz (1997) notes, fields denote arenas of production, circulation, and appropriation and exchange of goods, services, knowledge or status, and the competitive positions held by actors in their struggle to accumulate, exchange and monopolise different kinds of capitals, where the habitus emerges. Research into educational settings as social fields have illustrated the forces of interplay that bring out class (and racial) differences (see Reay, 1998; Lareau, 2000; McKnight and Chandler, 2012). For example, Reay's (1998) study of the education system in the United Kingdom ${ }^{2}$ shows the classed nature of women's involvement in their child's schooling and highlights the gap between the powerlessness and anxiousness of working-class habitus compared to the confidence and certainty of middle-class habitus.

The continuing legacy of Bourdieu within debates on global inequality is evident through Thomas Piketty's (2013) well-acclaimed Capital in the Twenty-First Century which highlights how accumulation of capital perpetuates inequality and shapes social change. Similarly, Savage et al.'s (2013) work in the UK, based on the Great British Class Survey, shows how inequalities in capital and power have led to the emergence of varying types of middle (e.g. the technical middle class) and working classes (e.g. the precariat). They reveal the psychological class experiences of snobbery, exclusion and refusal, as seen through Bourdieu's concept of symbolic violence. Within sociological debates, the overarching emphasis on the reproduction of symbolic orders has been criticised by many theorists. For example, Goldthorpe (2007) questions the soundness and originality of Bourdieu's sociological theory in relation to cultural capital and social reproduction. In particular, he objects to the transmission of cultural capital and how the education system is limited in the re-socialisation of such social transformation, whereby social reproduction is guaranteed. He draws on studies relating to upward social, educational and inter-generational mobility, critiquing the idea of the family as the only, or even the main, locus of transmission for cultural capital. Goldthorpe (2007) prefers to speak of cultural resources rather than cultural capital, alluding to the two different understandings of Bourdieu's work in terms of "domesticated" and "wild", which scholars such as Lizardo (2008) have defended. Laberge (1995, p. 136) notes that in addressing social transformation Bourdieu maintains that habitus is shaped by a "double historicity", as she refers to the history related 
to the socialisastion process and the particular trajectory of an individual on the one hand, and on the other, the historical work of preceding generations embodied by the individual (Bourdieu and Wacquant, 1992, p. 139).

A major critique of Bourdieu has been the deterministic nature of habitus supposedly rendering it unable to grasp the processes of social change (see Krais, 2006). Various theorists have noted that Bourdieu (2001) refers to social change by contesting doxic order and the existence of resistance (see McNay, 1999; Huppatz, 2012). This is critical for disciplines such as development studies that are primarily involved in understanding social and economic changes and social progress (see Rist, 2010) in post-colonial nations.

The concepts of misrecognition and symbolic violence are critical to social reproduction and transformation processes. By acquiring cultural capital, dominant agents maintain their ability to reproduce their dominance. The dominant group defends the integrity of what Bourdieu labels "doxa" - unquestioned beliefs embodied in actions and feelings (Crossley, 2001), as in the case of social-gender relations within a patriarchal system, or caste relations in the Indian society. In the Indian context, the term "caste" 3 has been widely used to describe ranked groups within rigid systems of social stratification, especially those within the Hindu society (though Christians in India are also stratified by caste relations). The structure of domination is also perpetuated through, in Bourdieu's terms, "symbolic violence" - a 'censored, euphemized, that is, misrecognizable, recognized violence' (Bourdieu, 1990, p. 126). Symbolic violence is "recognized" because everyone within a particular social field tacitly understands the "rules" and "stakes" of the "game", and the illusion that these are worth fighting for prevails (Moi, 1990, p. 270), such that symbolic violence is then 'the violence exercised upon a social agent with his or her complicity' (Bourdieu and Wacquant, 1992, p. 167). The concepts of symbolic violence, misrecognition, complicity and consent are useful to explore processes and forms of domination and violence reproduced in everyday interactions, social practices, institutional processes and dispositions.

\section{Development, social change and the symbolic order of gender}

In Masculine Domination, Bourdieu's ethnographic research on traditional Kabyles in Algeria is key to conceptualising gender classification and the gender order with regard to the social and sexual division of labour. Here, habitus is key, and its deeply embodied nature - it functions as a hinge between past and present, agency and structure (Crossley, 2001, p. 94) - shows the interconnectedness of an agent's 'everyday negotiations of the mundane' (Skeggs, 1997, p. 167) and large-scale power relations within a social system. Bodily differences between men and women relate to sexuality and human reproduction, and form the basis for the symbolic order of gender and the social practice of gender differentiation. While biological determinism allows socially constructed sexual difference to seem "natural", this masks the true, socially produced power relations between the sexes that present social-gender divisions as doxic - that is, they cannot be questioned (Moi, 1990). Bourdieu therefore rejects the inflexible, essentialist 
construction of the category of "woman" and conceptualises social change and transformation by representing gender relations as socially constructed, with which numerous socialist and materialist feminists concur (Moi, 1990). However, the case study on the Kabyle society mainly informs Bourdieu's Masculine Domination, as well as a reading of Virginia Woolf's To the Lighthouse, which may put a limit to generalisations on contemporary forms of gender domination in different spatial contexts.

A gender-specific habitus is thus an identity that internalises and embodies the division of labour between the genders. It does so through the social constructions of masculinity and femininity that shape the body, and it thus determines the individual's identity through notions of the body and bodily practices constructed as masculine or feminine. Masculine domination, according to Bourdieu, is merely 'a somatization of the social relations of domination' (Bourdieu, 2001, p. 23). Symbolic domination therefore implies "complicity" on the part of the dominated, and this complicity can thus be achieved only when both agents - the dominant and the dominated - have integrated this symbolic order into their habitus, which subsequently generates corresponding outcomes. The changing nature of habitus is also discussed in Bourdieu's work; for example, Silva (2016) maps Bourdieu's changing presentations of the notion of habitus, from that of a unified habitus to later conceptions of fragmentation.

However, feminist theorists such as Butler (1999) argue that performativity constructs and "performs" identity and power relations, but that by not addressing the power of language and speech in sociolinguistics, then marginalised group identities such as those of black and queer groups are challenged (see Fowler, 2003). Rituals and rite-de-passage ceremonies in the Indian context as documented in anthropological narratives (e.g. Fuller 1975) are examples of such performative acts that are also gendered (as well as caste-based) performativity. However, Bourdieu's reference to bodily practices and subjective representations has been defended (see Fowler, 2003; Adkins, 2004). Furthermore, Lovell (2000) suggests that a successful combinatory approach could be achieved by uniting Bourdieu's concept of habitus with Butler's account of performativity which unravels the social conditions of resistance.

Further, although Bourdieu's work does not address race issues, the concepts of habitus and cultural capital have helped to bring out the interactions of class, racial and ethnic disadvantages (Rollock, 2012; Reay, 2004). Research into how class interacts with race in relation to schooling shows how differential family habitus, differential possession and the activation of cultural capitals influence academic achievement in the UK (Rollock, 2012). A good level of scholarship pinpoints to a history of deficit understandings in terms of the resources and capital that minority non-white groups possess (Yosso, 2005; McKnight and Chandler, 2012). Just as habitus is socially constructed and culturally arbitrary, race is a product of social and historical construction at both individual and collective levels; furthermore, habitus relates to other behaviours, other interactions and the environment, so it reproduces inequalities rather than fractures them. 


\section{Gender capital}

In the words of Toril Moi, a feminist literary critic, Bourdieu's writings have been subject to "appropriation" where feminists have critically examined his concepts of capital and habitus and used them for feminist purposes (Moi, 1990, p. 265). As noted above, Bourdieu's typology of capital clarifies the complexities and multiplicity of power relations within a contemporary class system and gender order, which McCall (1992, p. 837) deems 'a powerfully elaborate conceptual framework for understanding the role of gender in the social relations of modern capitalist society'. In relation to gender, then, the category "woman" is not a homogeneous, singular identity but is instead lived and intimately experienced 'as a form of subjectivity inhabited through other categories' (Skeggs, 1996, p. 166).

By drawing on Bourdieu's typology of capital, various feminist scholars show how women possess a kind of "feminine cultural" capital themselves, but it is one that is also unquantifiable (Moi, 1991; McCall, 1992; Skeggs, 1997; Lovell, 2000; Huppatz, 2009). Skeggs (1997) found the white, working-class girls she studied to have a form of feminine capital that advantaged them in caring roles. McCall (1992) criticises Bourdieu for attributing feminine dispositions specifically to women and masculine dispositions only to men, though in the sense of performativity these concepts can help explore the use of capital in feminine and masculine bodies. For example, Skeggs' (1997) study of working-class girls saw femininity as a strategic performance to prevent their economic circumstances from deteriorating further. Nevertheless, Skeggs (ibid.) concluded that working-class femininities lack symbolic capital and can be used only in certain "restricted markets". However, there is evidence of growing demand for stereotypically feminine skills and capital within the labour market (Lovell, 2000). Indeed, both McNay (1999) and Lovell (2001) have drawn attention to a transition of feminine skills and capital within the labour market into previously masculine fields, reciprocally bestowing increased value on them within the service industries, for example.

Reay (2004) contends that Bourdieu neglected another type of capital: emotional capital. In extending the concept of capital into the realm of emotions, Reay (ibid.) draws on his inference regarding the practical and symbolic work that generates devotion and generosity, which manifests mostly in it being women's responsibility to maintain relationships (Bourdieu, 1998, p. 68). Although the middle classes are prone to emotional distress, working-class women are less likely to achieve emotional well-being because of the presence of poverty (Reay, 2004). Regarding emotional capital in educational fields, both workingand middle-class women are at risk of disadvantaging their children. In their quest for cultural capital through educational success, many middle-class mothers were seen to compromise their child's emotional well-being, while working-class mothers' pre-existing lack of emotional and cultural capital prevents their children from acquiring either of these.

Women ${ }^{4}$ are therefore seen as 'capital-bearing objects . . rather than as capitalaccumulating subjects in social space' (Lovell, 2000, p. 37), as the actors who contribute to the conversion of capital (Adkins, 2002). However, Huppatz (2009) 
argues that Bourdieu did in fact admit in Distinction that women could accumulate capital, saying that petit-bourgeois women placed value on beauty. Laberge's (1995) example of this capitalisation concerns female sports people in "masculine sports", and she suggests that the extent of beauty capital could be advantageous by neutralizing athletic cultural capital. She goes on to argue that women can capitalise on their own femininity, which is a form of learnt cultural capital. Skegg's (1997) identification of the forms of cultural capital has been used to show that femininity, as a disposition, is a form of capital (McCall, 1992).

Fowler (2000) writes that although failing to grasp the changing characteristics of patriarchy within different periods (notably that of capitalist modernity), Bourdieu's work does provide quality analytical tools such as "doxa" and the "illusio" of masculine domination. However, the androcentric bias of his works has been well noted (see McCall, 1992; Laberge, 1995) through the patrilinear nature of focus (see Silva, 2005; Huppatz, 2012) where gender is akin to a "secondary" principle (1984, p. 106) structuring the social space. Thus, Bourdieu recognises the strength of the structuring power of gender properties, as the volume and composition of capital is structured by gender properties within each social group. Drawing from McCall's (1992) work to rectify the androcentric bias in Bourdieu's study, Laberge (1995) advocates the integration of gender distinction into the concept of cultural capital and consequently into the concept of habitus. She delineates the differences in feminine and masculine traits of gender, which are forms of economic and symbolic power in fields such as sports. Huppatz (2009, p. 50) makes an important distinction between female and feminine capital: 'Female capital is the gender advantage that is derived from being perceived to have a female (but not necessarily feminine) body; whereas feminine capital is the gender advantage that is derived from a disposition or skill set learned via socialisation, or from simply being hailed as feminine (this occurs when one's body is recognised as feminine).

There have been disputes about the extent to which feminine and female capital is a positive force for women, or indeed feminine bodies. McCall (1992) illustrates the negativity faced by women who employ forms of female capital in the masculine field of the labour market, and how this sex-stereotyped behaviour is not mirrored in the actions of male capital in the masculine sphere. Thus, this struggle for power by women is also double-blind in that they risk their feminine capital should they 'act like men', yet are seen as inferior and weak should they subscribe to their femininity completely. This risky behaviour of working-class women also translates into the pursuit of emotional capital (Reay, 1998). Krais (2006) argues that Bourdieu's theoretical understanding of gender as a powerful principle of social differentiation opens up new analytical perspectives for feminist sociological theory whereby social practice allows space for resistance and change. However, the 'individual's conscious awareness of the doxa of the gender order does not by itself lead to fundamental social change' (ibid., p. 13).

\section{Capital/s and development studies}

Despite its widespread use, the meaning of the term "development" remains vague, tending to refer to a set of beliefs and assumptions about the nature of 
social progress (Rist, 2010; Cornwall and Eade, 2010) through many buzzwords such as poverty, underdevelopment, globalisation, gender etc. Historically, approaches to development have evolved out of debates on modernisation and Marxist dependency theory. Development discourses involve articulating knowledge and power; through these, particular concepts, theories and practices for social change in developing contests are created and reproduced (Escobar, 1995). Development policies and approaches in the 1990s focused on livelihood and poverty approaches, gender discourses, capability and rights-based notions of development that focused more on people as agents and participants. Within development discourses, the use of capitals, agency and endowments, as framed by Amartya Sen (1999) and Chambers and Conway (1992), has been appropriated by asset-based approaches that treat assets not just as resources but also as "agencies" to transform such resources (Bebbington, 1999; Moser and Dani, 2008). Fine's (1999) discussion of social capital in development studies and social science as part of the Post-Washington Consensus provides a critique of economic paradigms that exclude social relations, through both market and non-market forces. For Fine (1999, p. 16),

Economic "capital" is not a thing in the first place but is already social, global, exploitative, and embedded, in broader relations of which the state forms a part. The social can only be added to capital if it has been illegitimately excluded in the first place.

Social capital approaches in development studies deploy physical notions of networks and institutionalist perspectives (e.g. Woolcock and Narayan, 2000; Putnam, 2000; Coleman, 1988). However, these have focused on the social rather than the symbolic and cultural dimensions of development different from that of Bourdieu's notion of cultural or social capital and drawn from Coleman's framework of rational choice (see Harriss, 2002). As Fine (1999) notes, Bourdieu's construction of social capital relates to its content as meaning, but social capital in development studies relates more to the physical notions of capital, through networks and participation. Bebbington's (2007) series of notes ${ }^{5}$ regarding debates on social capital within development studies raises critical questions on the nature of the social capital agenda and calls for more enquiry and theorising by building bridges across institutional and political differences, particularly regarding social and material contexts that have gendered implications. This is discussed next in the context of a feminist habitus within development debates.

\section{Framing a development feminist habitus}

As discussed above, the concepts of habitus and the value of capitals depend on the field (context) of practice. Each agent's habitus is also heavily structured by its relational position within wider relationships and structures of social difference: nation, class, caste (in India), gender, ethnicity and so on. To frame a development feminist habitus, it is useful to engage with the key concepts of capitals, symbolic violence and misrecognition by integrating theories of Bourdieu, gender and 


\section{Gender and development}

Table 2.1 Meshing of Theories: Pierre Bourdieu, Gender and Development Discourses

\begin{tabular}{|c|c|c|}
\hline Bourdieu & Gender Discourses & Development Discourses \\
\hline Habitus & $\begin{array}{l}\text { Naturalisation of gender, } \\
\text { race and ethnic (caste) } \\
\text { discourses }\end{array}$ & $\begin{array}{l}\text { (Re)presentation of gender, ethnic, } \\
\text { caste and racial conflict }\end{array}$ \\
\hline Field & $\begin{array}{l}\text { The constituted socio- } \\
\text { historical meaning of } \\
\text { gender, body, ethnicity } \\
\text { Orientialism, } \\
\text { ethnocentrism, } \\
\text { Eurocentrism } \\
\text { Households and family } \\
\text { as site of subordination }\end{array}$ & $\begin{array}{l}\text { Common sense explanations } \\
\text { of gender bias, racial } \\
\text { bias, modernisation and } \\
\text { Westernisation, othering and } \\
\text { individual sexism, caste practices } \\
\text { Control of body, sexuality and } \\
\text { reproduction } \\
\text { Groups represented and those "left } \\
\text { out" }\end{array}$ \\
\hline $\begin{array}{l}\text { Symbolic } \\
\text { Violence }\end{array}$ & $\begin{array}{l}\text { Male and social bias as } \\
\text { status quo }\end{array}$ & $\begin{array}{l}\text { Gender bias in neutral language } \\
\text { to legitimise status quo, power } \\
\text { structures and conflict }\end{array}$ \\
\hline Misrecognition & Erasure of others & $\begin{array}{l}\text { Gendered, social and caste } \\
\text { structures not perceived as } \\
\text { oppression but as legitimate }\end{array}$ \\
\hline
\end{tabular}

Adapted from McKnight and Chandler (2012)

development (see Table 2.1). Thus, Bourdieu's class-oriented ideas can be utilised in conjunction with race, caste and gender for a fuller understanding of development contexts. Each of these is discussed in detail within subsequent sections.

\section{Gendered habitus and the household}

As Bourdieu (1977) explains, habitus is formed and directed by influential forces such as family, education, environment and peer groups. In Bourdieu's formulation, habitus is acquired through experience, and its norms, values and dispositions propel individuals of similar backgrounds to act in particular ways. Their habitus indeed acts as an 'internalized set of tacit rules governing strategies and practices in the field' (Moi, 1990, p. 271). Thus, habitus is legitimised in contexts where social norms such as gender are biased and hierarchial, with this example tending to be normalised through gendered practices such as patriarchy (e.g. unequal property rights for men and women) or even caste practices that legitimise social hierarchy and oppression, particularly in developing contexts. Gender theorists (see Tinker, 1990; Kabeer, 1994; Elson, 1995) have long drawn attention to the norms and practices that engender male bias in development practices and policies, as well as within intra-household relations. Gender relations are manifested not only in the division of labour and resources between men and women but also in the ascription to men and women of different abilities, traits and behaviour patterns, subject to cultural and temporal contexts (i.e. they are dynamic in nature, and they sanction and legitimise unequal power relations), regardless of - though 
in some ways because of - the aforementioned influential forces and personal experiences.

Discussions on habitus, capital and fields allow us to address questions about how to understand these inequalities, how and why women have been systematically excluded from power and equality, how and why women's contributions have been undervalued and trivialised and, furthermore, how their seclusion to certain domains such as the domestic sphere has been organised. For this, it is useful to treat "gender" as the central category and "power" as an important instrument in distributing resources, labour and income (Young, 1993; Kabeer, 1994). If gender is socially constructed, it remains to be seen what form this social construction takes and what its organizing principle and consequences are (Moi, 1990, p. 268). The distribution of resources and organisation of labour within households were central focuses of the domestic labour debate during the 1970s; through these, feminists sought to understand the specific location of women in capitalist society (Walby, 1997; 2009). The family has occupied a central place in feminist theory, and women's subordination in this sphere has various origins - for example, male violence, control over women's sexuality and reproduction, the economics of domestic labour and state regulation of family life. In the early 1980s Marxists and socialist feminist economists also debated the usefulness of the patriarchal mode of production, seeking to extend Marxism beyond its market- and production-centric focus to include and value social reproductive care (Folbre, 1986). Consequently, many theorists have sought to locate the cause of women's subordination in the family, but now it is widely recognised that women's position within households needs explaining in terms of wider social and economic structures in society; this is where Bourdieu's social theory has great significance. The mechanisms of co-operation and conflict within the household, as well as the dynamics of bargaining power shape the distribution of work, income and assets (Agarwal, 1994; Kabeer, 1994). These gender roles and norms influence the intergenerational transfer of various types of capital within households and they do so through access and control (and often vulnerability). Bodily differences between men and women therefore relate to sexuality and the reproduction of human and social order, illustrating the symbolic order of gender and the social practice of gender differentiation.

\section{Gendered capital and intersecting differences}

The processes of how different capitals and resources are accumulated or lost by different social groups, such as women, have been included in debates on poverty and empowerment, particularly in social capital approaches (see Molyneux, 2002; Bebbington, 2007; Maclean, 2010). Bourdieu's discussion on capitals relates to the structure of the economic context and its materiality and sheds light on society through the movement of diverse capital through social spaces as it is accumulated or lost by individuals (Skeggs, 1996, p. 8). Evidence shows that gender relations affect all aspects of poverty, including income, opportunity, security and empowerment (Narayan et al., 2000), acting as both cause and characteristic 


\section{Gender and development}

of poverty. It is often actually harder for women to transform their capabilities into incomes or well-being precisely because of gender inequalities in economic resources and gender bias in institutions, irrespective of the household headship factor. The interaction of households with other economic and social institutions that perpetuate gender inequalities in terms of access to services and markets has been illustrated (Agarwal, 1994; Elson, 1995; Harriss-White and Heyer, 2010). Without falling into the trap of homogenisation and essentialism, it is critical to understand the experiences of women from different social groups and regions in relation to poverty's multidimensionality, both in temporal and spatial terms.

Notably, though, intersectionality as an overlapping or intersecting feature of social identities and related systems of domination and oppression is key to understanding gendered experiences of class and race (see Crenshaw, 1991; McCall, 1992; Walby, 2007). Ghadially (2007) draws an unclear verdict on women's gains from economic and cultural globalisation in urban India, as there are benefits for some sections of women but generally increased insecurities and vulnerabilities. This suggests that the interplay of class, caste, gender and region plays an important role in social reproduction and transformation, and it provides more evidence on how gender navigates women's accumulation of capital. By relocating the significance of class, this 'provide[s] the relations in which capitals come to be organised and valued' in terms of who is able to attain access to resources and achieve legitimation through social positioning (Skeggs, 1996, p. 9). For example, the revolution of information and communication technologies (ICTs) in developing contexts brought changes to women's work, income and empowerment, but this was mostly to educated, middle-class women and girls. Some narratives do show ICTs benefiting poorer working-class women and their families directly and indirectly (Arun, Heeks and Morgan, 2007). In part, though, this benefit involved empowerment in terms of accessing new capitals and assets: new skills, new income, new physical assets, new contacts. Habitus, therefore, also carries the notion of history, or for Bourdieu "embodied history" (1990, p. 56), so it is generative of different outcomes (Lawler, 2004, p. 112) for different groups. As an example in the Indian context, habitus can generate different social outcomes for different caste groups in the same field. As recognition and legitimacy of social practices often emerge and get reified through daily practices within and between different forms of social strata, then 'a group, class, "gender", region, or nation, begins to exist as such . . . only when it is distinguished, according to one principle or another, from other groups, that is, via cognition and recognition' (Bourdieu, 1990, p. 139).

Different forms of social stratification dictate relative positions of groups of individuals within differentiated strata; these forms and strata may be specific or generalised characteristics (or sets of these) that vary between and within societies. As Bourdieu and Passeron note in Reproduction (2000, p. xv):

Every power to exert symbolic violence, i.e. every power which manages to impose meanings and to impose them as legitimate by concealing the power relations which are the basis of force, adds its own specifically symbolic force to those power relations. 
Molyneux (2002) questions the gender-blind assumptions that underpin social capital discussions within development and poverty discourses, as these notions of social capital are often seen as the "capital of the poor", but more specifically that of the "poor women". This is because women are implicitly expected to have the time available to assume the costs of building and sustaining the associational life that can underpin coping strategies (Molyneux, 2002). Further, micro-finance institutions mobilise social capital in the form of a group guarantee and target women because of the effectiveness of their social capital as collateral (Maclean, 2010). Thus, notions of capital often promote deficit views of certain groups, as we have seen in relation to ethnic minorities. It may be more apt to configure asymmetrical power relationships that limit the conversion of certain types of capital (see Wallace, 2016). This does not seem the case for the emerging evidence extolling the benefits of social network participation such as self-help group (SHG) membership of women who are themselves questionable (see Balasubramanian, 2013). However, Arun et al. (2016) find that mere membership of social bonding networks does not affect welfare. The implication is that although such capital of homogenous or closed groups may give members much information, this may have no impact on their household consumption; instead, bridging these networks across social groups may improve social relations based on norms and networks that spill over to the household, community and wider society. In contrast, though, Mayoux (2001) shows that women's lack of income is not so much caused by their deficient social capital but is more a result of discriminatory practices and those institutions that are sustained through men's social capital and which limit women's access to markets, other assets and other institutional spheres.

\section{Symbolic violence: domination and power}

The women in development (WID) discourses based on the modernisation agenda and Western feminism focus on equality in work and education, reproductive rights and sexual freedom. Such notions of essentialist approaches to gender as a fixed set of characteristics were problematic (see Bulbeck, 1998; Walby, 2007); when women have "plural identities", as seen, for example, with caste, ethnicity and sexuality, seems preferable. The gender and development (GAD) discourses focus on the "social relations" framework that unveils the social structures, processes and gender division of labour within institutions such as the household, the community, the market and the state, and they highlight the centrality of power relations (see Kabeer, 1994). Mohanty (1991) says the notion of the "thirdworld woman" is questionable, as the content of gender order (e.g. the sexual division of labour) changes between environments, and the homogenisation of class, race, religion and the daily material practices of women is common. Differences between women are accentuated in the Indian context. For instance, Adivasi women's experiences vary from other women in hegemonic gender narratives, as gender intersects with their Adivasi ethnicity, social grouping and resource structures. Paradoxically, symbolic violence is also misrecognisable because 
dominated agents fail to recognise their own domination and instead understand their situation to be "the natural order of things" (Bourdieu, 1979).

The ways in which gender mediates between the habitus and the field are particularly prominent in relation to the family and its impact on women's subordination. The family occupies a central place in feminist theory as women's subordination has been intimately related to various forms of and practices within it, for example, male violence, control over women's sexuality and reproduction, the economics of domestic labour and state regulation of family life. Evidence on the prevalence of abuse within the private sphere and households has indeed rendered it a site of oppression - one that operates through gendered ideologies of power and hierarchy (see Garcia and McManimon, 2011). Bourdieu's conceptualisation of symbolic violence $(1990,2000)$ helps focus on direct forms of interpersonal violence such as domestic and/or sexual abuse as well as the invisible nature of symbolic violence as a mode of domination (Morgan and Bjorkert, 2006). Forms of symbolic violence are also embedded in the "normal" routines of everyday life, and they pervade cultural and gendered practices such as dowry and son preference (or daughter devaluation) (Kishwar, 1999; Purewal, 2010) in the South Asian context. These narratives suggest the need for a broader understanding and conceptualisation of violence as the normalisation of norms and practices often exposes forms of gender subordination.

\section{Social reproduction in a global field}

For Bourdieu, a field is any social space with 'a set of objective power relations that impose themselves on all who enter the field and that are irreducible to the intentions of the individual agents or even to the direct interactions among the agents' (1985, p. 724). As such, migration changes individuals' habitus, testing its durability and capability (Thatcher and Halvorsrdu, 2016) or transforming and reinventing it (Clayton et al., 2009). Migrants therefore engage in the game, follow rules and interactions, and compete for and struggle over the game's stakes, or rewards, as is evident with economic migration when people strive for more economic opportunities through social mobility and inter-generational mobility, aspiring for better life chances. According to Oliver and Reilly (2010, p. 51), British migrants to Spain are essentially placed in two social spaces, though the 'orientation is towards the British social space'.

Studying the Kabyle tribe in Algeria, Bourdieu and Sayad (1964) point to the internalisation of culture even when migration happens. Questions do arise as to what extent habitus can reinvent itself in migrants' encounters through both the field of work and human capital. Many studies have extended Bourdieu's notion of field to a global field of power, with agents both positioned and position-taking within the field (see Marginson, 2008; Naidoo, 2004). Friedman (2016) notes that a person experiences habitus clivé, or cleft habitus, when their "conditions of existence" change so dramatically over the course of their life that they feel their dispositions are losing coherency and they experience a sense of self torn by dislocation and internal division. Considering this, global migration is clearly 
a "global field" that is relevant to habitus, rules and games. In this, dominant systems of distinction based on class, occupational prestige, gender, race and economic capital seem contestable, and processes of adaptation lead to the reproduction or transformation of hierarchy and conflict.

\section{Conclusion}

This chapter has set the scene through a Bourdieusian lens for analytical and theoretical foci on gender, feminism and development, as well as interactions between social thought and ideas, and practices and experiences. It has identified the ways gendered, racialised and other power-laden norms are embedded in everyday habitus and fields, showing how certain forms of habitus and capital reproduce those norms in development discourses. The various social meanings and values attached to social constructs are constitutive of social hierarchies and thus indirectly determine the materiality of social contexts through the distribution of power and resources, including in spheres that pervade into public spheres. To gain a sociological understanding of the complex interactions between structure and agency through mobilities and new (and multiple) domains, habitus is a handy tool with 'systems of durable, transposable dispositions, structured structures predisposed to function as structuring structures' (Bourdieu, 1990, p. 53). This book attempts to shift from the deterministic and essentialist nature of habitus, as studies on intra-household relations in development contexts, for example, refer to processes of bargaining with and contesting social norms through "co-operative conflict" and forms of resistance.

The next chapter explores a discussion of women in Kerala using a Bourdieusian framework that operationalises the ideas of habitus, field and forms of capital. By using these, it is possible to consider the individual (through habitus) specifically through the fields of work and households - alongside values placed on different knowledge (capitals, symbolic violence) strategically and in relation to policies and practices.

\section{Notes}

1 Habitus manifests in ways of speaking, it is not merely confined to the body but is in dispositions, attitudes and tastes, thus cutting across conventional mind/body splits (Lawler, 2004, p. 111).

2 Similarly, Lareau's (2000) comparative study of working-class and middle-class families in California shows the importance of symbolic access, where working-class parents leave the schooling to their children's teachers but middle-class parents become intensely involved.

3 India's caste system is unique in its complexity and in the degree to which the constituent groups are cohesive and self-regulating (see Searle-Chatterjee and Sharma, 1994). Indeed, there are significant differences in caste prevalent within India from region to region and even from caste to caste within the same locale.

4 Initially, Bourdieu's capitals were regarded as gender neutral (McCall, 1992) and without reference to race (Lovell, 2000), but his work in Masculine Domination explains gender as a relation of domination through the interplay of practice, habitus and symbolic order (Krais, 2006). 


\section{Gender and development}

5 Drawing on earlier works of Fine (1999; 2002) and Harriss (2002), Bebbington suggests the following: (1) Interest in social capital derived from its implicit concern for more empirical material and grounded analysis. (2) Meso-level concepts related more to empirical and context-specific variation, but also respected notions of both agency and structure. (3) The enablement of a balanced discussion of the social, political and economic, both conceptual and practical, is grounded on the basis of a political and cultural economy.

\section{References}

Adkins, L. (2002). Revisions Gender and Sexuality in Late Modernity. Buckingham: Open University Press.

Adkins, L. (2004). 'Introduction: Feminism, Bourdieu and after.' The Sociological Review, $52(\mathrm{~s} 2)$, pp. 1-18.

Agarwal, B. (1994). A Field of One's Own: Gender and Land Rights in South Asia. Cambridge: Cambridge University Press.

Agarwal, B. (1997). 'Bargaining and gender relations: Within and beyond the household.' Feminist Economics, 3(1), pp. 1-51.

Arun, S., Annim, S., \& Arun, T. (2016). Do All Networks 'Work'? The Mediating Role of Social Networks on Consumption Expenditure in India. Sociology, 50(3), 522-541.

Arun, S., Heeks, R. and Morgan, S. (2007). 'ICT initiatives, women and work: Reproducing or changing gender inequalities.' In: Ghadially, R. (ed.), Urban Women in Contemporary India: A Reader, pp. 297-308. New Delhi: SAGE Publications.

Balasubramanian, S. (2013). 'Why micro-credit may leave women worse off: Noncooperative bargaining and the marriage game in South Asia.' The Journal of Development Studies, 49(5), pp. 609-623.

Bebbington, A. (1999). 'Capitals and capabilities: A framework for analyzing peasant viability, rural livelihoods and poverty.' World Development, 27(12), pp. 2021-2044.

Bebbington, A. (2007). 'Social capital and development studies II: Can Bourdieu travel to policy?' Progress in Development Studies, 7(2), pp. 155-162.

Bourdieu, P. (1977). Outline of a Theory of Practice. Cambridge: Cambridge University Press.

Bourdieu, P. (1984). Distinction: A Social Critique of the Judgement of Taste. Cambridge MA and London: Harvard University Press. (Original work published in 1979.)

Bourdieu, P. (1985). 'The social space and the genesis of groups.' Theory and Society, 14(6), pp. 723-744.

Bourdieu, P. (1986). 'The forms of capital.' In: Richardson, J. (ed.), Handbook of Theory and Research for the Sociology of Education, pp. 241-258. New York: Greenwood Press.

Bourdieu, P. (1990). The Logic of Practice (Trans. R. Nice). Cambridge: Polity Press.

Bourdieu, P. (1997). 'The forms of capital.' In: Halsey, A., Lauder, H., Brown, P. and Stuart Wells, A. (eds.), Education: Culture, Economy and Society, pp. 46-59. Oxford: Oxford University Press.

Bourdieu, P. (1998). The State Nobility: Elite Schools in the Field of Power. Stanford, CA: Stanford University Press.

Bourdieu, P. (2000). Pierre Bourdieu. London, UK: SAGE Publications.

Bourdieu, P. (2001). Masculine Domination (Trans. R. Nice). Cambridge: Polity Press.

Bourdieu, P (1979). 'Symbolic power.' Critique of Anthropology, 4(13-14) pp. 77-85.

Bourdieu, P. and Sayad, A. (1964). Le déracinement: la crise de l'agriculture traditionnelle en Algérie, 14. Paris: Editions de Minuit. 
Bourdieu, P. and Wacquant, L. J. (1992). An Invitation to Reflexive Sociology. Chicago and London: University of Chicago Press.

Bourdieu, P. and Wacquant, L. J. (2002). 'The organic ethnologist of Algerian migration.' Ethnography, 1(2), pp. 173-182.

Bulbeck, C. (1998). Re-Orienting Western Feminisms: Women's Diversity in a Postcolonial World. Cambridge: Cambridge University Press.

Chambers, R. and Conway, G. R. (1992). 'Sustainable rural development: Practical concepts for the 21st century.' Ids discussion paper no. 296. Institute of Development Studies, Brighton.

Butler, J. (1999). 'Bodily inscriptions, performative subversions.' In: Butler, J. (ed.), Feminist Theory and the Body: A Reader, pp. 416-422. New York: Routledge.

Clayton, J., Crozier, G. and Reay, D. (2009). 'Home and away: Risk, familiarity and the multiple geographies of the higher education experience.' International Studies in Sociology of Education, 19(3-4), pp. 157-174.

Coleman, J. S. (1988). 'Social capital in the creation of human capital.' American Journal of Sociology, pp. S95-S120.

Colley, H. (2006). 'Learning to labour with feeling: Class, gender and emotion in childcare education and training.' Contemporary Issues in Early Childhood, 7(1), pp. 15-29.

Cornwall, A. and Eade, D. (2010). Deconstructing Development Discourse: Buzzwords and Fuzzwords. Oxfam and Rubgy: Practical Action Publishing.

Crenshaw, K. (1991). 'Mapping the margins: Intersectionality, identity politics, and violence against women of color.' Stanford Law Review, 43(6), pp. 1241-1299.

Crossley, N. (2001). The Social Body: Habit, Identity and Desire. London: SAGE Publications.

Crossley N. (2008). 'Social class.' In: Grenfell, M. (ed.), Pierre Bourdieu: Key Concepts, pp. 87-100. Stocksfield, UK: Acumen.

Elson, D. (1995). Male Bias in the Development Process (2nd Edition). Manchester: Manchester University Press.

Escobar, A. (1995). Encountering Development: The Making and Unmaking of the Third World. Princeton: Princeton University Press.

Fine, B. (1999). 'The developmental state is dead - long live social capital?' Development and Change, 30(1), pp. 1-19.

Fine, B. (2002). Social Capital Versus Social Theory. London: Routledge.

Folbre, N. (1986). 'Hearts and spades: Paradigms of household economics.' World Development. 14, 2(1), pp. 245-255.

Friedman, S. (2016). 'Habitus clivé and the emotional imprint of social mobility.' The Sociological Review, 64(1), pp. 129-147.

Fuller, C. J. (1975). 'The internal structure of the Nayar caste.' Journal of Anthropological Research, 31(4), pp. 283-312.

Fowler, B. (2000). Reading Bourdieu on Society and Culture. Oxford and Malden, MA: Blackwell Publishers/The Sociological Review.

Fowler, B. (2003). 'Reading Pierre Bourdieu's Masculine Domination: Notes towards an intersectional analysis of gender, culture and class.' Cultural Studies, 17(3-4), pp. 468-494.

Garcia, V. and McManimon, M. (2011). 'Gendered justice: Intimate partner violence and the criminal justice system.' Contemporary Sociology: A Journal of Reviews, 41(6), pp. 835-836.

Ghadially, R. (ed.). (2007). Urban Women in Contemporary India: A Reader. London: SAGE Publications. 
Goldthorpe, J. H. (2007). 'Cultural capital: Some critical observations.' Sociologica, 1(2), doi: $10.2383 / 24755$.

Harriss, J. (2002). Depoliticizing Development: The World Bank and Social Capital. London: Anthem Press.

Harris-White, B. and Heyer, J. (2010). The Comparative Political Economy of Development: Africa and South Asia. New York: Routledge.

Huppatz, K. (2009). 'Reworking Bourdieu's capital: Feminine and female capitals in the field of paid caring work.' Sociology, 43(1), pp. 45-66.

Huppatz, K. (2012). Gender Capital at Work: Intersections of Femininity, Masculinity, Class and Occupation. London: Palgrave Macmillan.

Jackson, C. (1998). 'Rescuing gender from the poverty trap.' In: Jackson, C. and Pearson, R. (eds.), Feminist Visions of Development: Gender Analysis and Policy, pp. 39-64. New York: Routledge.

Kabeer, N. (1994). Reversed Realities: Gender Hierarchies in Development Thought. London: Verso Books.

Kishwar, M. (1999). Off the Beaten Track: Rethinking Gender Justice for Indian Women. New Delhi: Oxford University Press.

Krais, B. (2006). 'Gender, sociological theory and Bourdieu's sociology of practice.' Theory, Culture and Society, 23(6), pp. 119-134.

Laberge, S. (1995). 'Toward an integration of gender into Bourdieu's concept of cultural capital.' Sociology of Sport Journal, 12, pp. 132-132.

Lareau, A. (1989). Home Advantage: Social Class and Parental Involvement in Elementary Education. London: Falmer.

Lareau, A. (2000). Home Advantage: Social Class and Parental Intervention in Elementary Education. Lanham, MD: Rowman \& Littlefield Publishers.

Lawler, S. (2004). 'Rules of engagement: Habitus, power and resistance.' The Sociological Review, 52(s2), pp. 110-128.

Lawler, S. (2005). 'Disgusted subjects: The making of middle-class identities.' The Sociological Review, 53(3), pp. 429-446.

Lizardo, O. (2008). 'Comment on John Goldthorpe/5. 'Three cheers for unoriginality.' 'Sociologica, II, I. doi: 10.2383/26580

Lovell, T. (2000). 'Thinking feminism with and against Bourdieu.' Feminist theory, 1(1), pp. 11-32.

Lovell, T. (2001). 'Thinking feminism with and against Bourdieu.' The Sociological Review, 49(s1), pp. 27-48.

Lovell, T. (2004). 'Bourdieu, class and gender: The return of the living dead?' The Sociological Review, 52(s2), pp. 35-56.

Lovell, T. (ed.). (2007). (Mis)recognition, Social Inequality and Social Justice: Nancy Fraser and Pierre Bourdieu. London: Routledge.

Maclean, K. (2010). 'Capitalizing on women's social capital? Women-targeted microfinance in Bolivia.' Development and Change, 41(3), 495-515.

Marginson, S. (2008). 'Global field and global imagining: Bourdieu and worldwide higher education.' British Journal of Sociology of Education, 29(3), pp. 303-315.

Mayoux, L. (2001). 'Tackling the down side: Social capital, women's empowerment and micro-finance in Cameroon.' Development and Change, 32(3), pp. 435-464.

McCall, L. (1992). 'Does gender fit? Bourdieu, feminism, and conceptions of social order.' Theory and Society, 21(6), pp. 837-867.

McKnight, D. and Chandler, P. (2012). 'The complicated conversation of class and race in social and curricular analysis: An examination of Pierre Bourdieu's interpretative framework in relation to race.' Educational Philosophy and Theory, 44(s1), pp. 74-97. 
McNay, L. (1999). 'Gender, habitus and the field: Pierre Bourdieu and the limits of reflexivity.' Theory, Culture and Society, 16(1), pp. 95-117.

Mohanty, C. T. (1991). 'Cartographies of struggle: Third world women and the politics of feminism.' In: Mohanty, C. T., Russo, A. and Torres, L. (eds.), Third World Women and the Politics of Feminism, pp. 1-50. Indianapolis: Indiana University Press.

Moi, T. (1990). 'Feminism and postmodernism: Recent feminist criticism in the United States.' In: Lovell, T. (ed.), British Feminist Thought: A Reader, pp. 367-376. Oxford: Basil Blackwell.

Moi, T. (1991). 'Appropriating Bourdieu: Feminist theory and Pierre Bourdieu's sociology of culture.' New Literary History, 22(4), pp. 1017-1049.

Molyneux, M. (2002). 'Gender and the silences of social capital: Lessons from Latin America.' Development and Change, 33(2), pp. 167-188.

Morgan, K. and Björkert, S. T. (2006). 'I'd rather you'd lay me on the floor and start kicking me: Understanding symbolic violence in everyday life.' Women's Studies International Forum, 29(5), pp. 441-452.

Moser, C. O. N. and Dani, A. A. (2008). Assets, Livelihoods and Social Policy. Washington, DC: World Bank.

Naidoo, R. (2004). 'Fields and institutional strategy: Bourdieu on the relationship between higher education, inequality and society.' British Journal of Sociology of Education, 25(4), pp. 457-471.

Narayan, D., Patel, R., Schafft, K., Rademacher, A. and Koch-Schulte, S. (2000). Voices of the Poor: Can Anyone Hear Us? Washington, DC: World Bank.

Oliver, C. and O'Reilly, K. (2010). 'A Bourdieusian analysis of class and migration habitus and the individualizing process.' Sociology, 44(1), pp. 49-66.

Piketty, T. (2013). Capital in the 21 st Century. Cambridge: Harvard University.

Purewal, N. K. (2010). Son Preference: Sex Selection, Gender and Culture in South Asia. Oxford and New York: Berg.

Putnam, R. D. (2000). 'Bowling alone: America's declining social capital.' In Culture and politics, pp. 223-234. New York: Palgrave Macmillan.

Reay, D. (1998). Class Work: Mothers' Involvement in Their Children's Primary Schooling. London: University College London.

Reay, D. (2004). 'It's all becoming a habitus': Beyond the habitual use of habitus in educational research.' British Journal of Sociology of Education, 25(4), pp. 431-444.

Rist, G. (2010). 'Development as a buzzword.' In: Cornwall, A. and Eade, D. (eds.), Deconstructing Development Discourse, pp. 65-96. Oxfam and Rugby: Practical Action Publishing.

Rollock, N. (2012). 'The invisibility of race: Intersectional reflections on the liminal space of alterity.' Race, Ethnicity and Education, 15(1), pp. 65-84.

Savage, M., Devine, F., Cunningham, N., Taylor, M., Li, Y., Hjellbrekke, J., Le Roux, B., Friedman, S. and Miles, A. (2013). 'A new model of social class? Findings from the BBC's Great British Class Survey experiment.' Sociology, 47(2), pp. 219-250.

Searle-Chatterjee, M. and Sharma, U. (1994). Contextualising Caste: Post-Dumontian Approaches. Oxford: Blackwell.

Sen, A. (1993). 'Capability and well-being.' In: Nussbaum, M. and Sen, A. (eds.), The Quality of Life, pp. 30-53. New York: Oxford University Press.

Sen, A. (1999). Development as Freedom. Oxford: Oxford University Press.

Sharma, U. (1980). Women, Work and Property in North West India. London: Tavistock Publications.

Silva, E. B. (2005). 'Gender, home and family in cultural capital theory.' The British Journal of Sociology, 56(1), pp. 83-103. 


\section{Gender and development}

Silva, E.B. (2016). Unity and fragmentation of the habitus. The Sociological Review, 64(1), pp. 166-218.

Silva, E.B. (2016). Unity and fragmentation of the habitus. The Sociological Review, 64(1), pp. 166-183.

Skeggs, B. (1996). Becoming Respectable: An Ethnography of White Working-Class Ideology. London: Routledge.

Skeggs, B. (1997). 'Classifying practices: Representations, capitals and recognitions.' Class Matters, In: Mahony, P. and Zmroczek, C. (eds.), Class matters: 'Working-class' women's perspectives on social class, pp. 123-140. London: Tayler \& Francis.

Swartz, D. (1997). Power and Culture: The Sociology of Pierre Bourdieu. Chicago: The University of Chicago Press.

Thatcher, J. and Halvorsrud, K. (2016). 'Migrating habitus.' In: Thatcher, J., Ingram, N., Burke, C. and Abrahams, J. (eds.), Bourdieu: The Next Generation. The Development of Bourdieu's Intellectual Heritage in Contemporary UK Sociology, pp. 88-106. Abingdon and New York: Routledge.

Tinker, I. (1990). 'The making of the field: Advocates, practitioners and scholars.' In: Tinker, I. (ed.), Persistent Inequalities: Women and World Development, pp. 27-53. Oxford: Oxford University Press.

Walby, S. (2007). 'Complexity theory, systems theory, and multiple intersecting social inequalities.' Philosophy of the Social Sciences, 37(4), pp. 449-470.

Walby, S. (2009). Globalization and Inequalities: Complexity and Contested Modernities. London: SAGE Publications.

Walby, S. (1997). Gender Transformations. London: Routledge.

Wallace, D. O. (2016). 'Re-interpreting Bourdieu, belonging and black identities: Exploring "Black" cultural capital among black Caribbean youth in London.' In: Thatcher, J., Ingram, N., Burke, C. and Abrahams, J. (eds.), Bourdieu: The Next Generation: The Development of Bourdieu's Intellectual Heritage in Contemporary UK Sociology, pp. 37-54. Abingdon and New York: Routledge.

Woolf, V. (1927) To the Lighthouse. London: Hogarth.

Woolcock, M. and Narayan, D. (2000). 'Social capital: Implications for development theory, research, and policy.' The World Bank Research Observer, 15(2), pp. 225-249.

Yosso, T. J. (2005). 'Whose culture has capital? A critical race theory discussion of community cultural wealth.' Race Ethnicity and Education, 8(1), pp. 69-91.

Young, K. (1993). Planning Development With Women. London: Palgrave Macmillan. 


\section{Situating gender capital in Kerala}

India has always been a land of contrasts, as reflected in Mark Twain's writings from the nineteenth century. The country's recent growth trajectory has much been commented on and is often noted as the "rise of the elephant" or similarly described as "the giant awakens"; India is considered a growth hotspot in South Asia and even globally. Indeed, the country's high growth rate has attracted much attention, as the recent World Bank forecasts predict that its GDP growth will remain strong at 7.6 per cent in 2016 and 7.7 per cent in 2017 (World Bank, 2015). In 2014, India was placed within the medium human development group of the United Nations Development Programme's (UNDP) Human Development Index (HDI) with a ranking of 130 out of 188 countries. With the world's second-largest population after China, India is a country with diverse communities, inconsistent rates of social and economic development, and sharp inequalities - as the inequalities in the HDI indices within regions and social groups evidence. For example, figures from the second India Human Development Report (2011) show that the state of Kerala was ranked first, followed by Delhi, Himachal Pradesh and Punjab. In light of such contrasts, the primary aim of this chapter is to deconstruct the socio-economic development experience of the Indian state of Kerala to understand the centrality of social and gendered divisions and fractures in the so-called "Kerala model", especially in relation to the Indian context, thus making a case for exploring the nature of gender capital.

\section{Development challenges for India}

India's neo-liberal market approach since the 1990s has been a marked departure from the Swadeshi or socialist policies it followed for decades in its post-colonial period, primarily through state ownership of key sectors. Contrary to the success story economists such as Hicks (1989, cited in Hossain, Kathuria and Islam, 2010) had predicted, post-independence India was plagued with dismal economic development and increasing national debt, all which then initiated a free market policy approach, relying on privatisation of key sectors, structural adjustment measures and foreign direct investment. ${ }^{1}$ The country's growth since the 1990 s has been led by the information technology sector. Studies point to the slow progress in the diversification of India's employment structure during the 2000s (Thomas, 


\section{Situating gender capital in Kerala}

2012). Recent initiatives by the Bharathiya Janata Party (BJP) government led by Narendra Modi, such as "Make in India", have been implemented to rekindle growth and increase employment generation in the manufacturing sector. Other radical policies such as demonetisation measures to address structural issues in the monetary sector are yet to yield results for both the country's growth and related distributional aspects. The rising levels of inequality has to be addressed by accelerating the responsiveness of poverty reduction to growth and promoting inclusion, including enhancing gender equality (World Bank, 2015). Other countries in South Asia such as Bangladesh, which have lower Gross National Income (GNI) per capita than India, are surpassing India in their UNDP Gender Development Index (GDI). This illustrates how economic prosperity does not necessarily translate into increasing social and gender equity.

\section{Gender equality and development in India}

The rates of social development throughout India and the consequent extent of poverty differ widely between states, regions and social groups (Singh, 2015). Despite the country's decades of development planning, women have experienced negative effects of specific policies, highlighting their economic and social insecurity. For example, the Structural Adjustment Policies (SAPs) rendered women and children the worst off from resultant decreasing social services spending (Cornwall et al., 2007). This is sometimes overlooked because data collection on households with male headships disregards the gender aspect of poverty within the family (Bardhan, 1993; Banerjee, 1998). Within rural settings, men are more likely to own land and technology or work in higher-paid roles in agriculture (Agarwal, 1994); in urban communities, low female employment earnings and high dependency on male family members contributes to female poverty (Banerjee, 1998). Additionally, the increasing industrialisation of urban areas has led to mass labour migration to these regions, whilst a lack of informal work for women has led them to take precarious work (Upadhyay, 2000; Kapadia, 2010).

Women's participation in the Indian economic sphere is increasing mainly through acceleration in the service sector (see Ghadially, 2007). However, compared to a global average of 40 per cent, and an Asia-Pacific of 38 per cent, in South Asia, women formed only 20 per cent of wage earners in India (The Global Gender Gap Report, 2016). Compared to a global average of 40 per cent, and an Asia-Pacific of 38 per cent, in South Asia, women formed only 20 per cent of wage earners in India. However, the Global Gender Gap Report (2016) shows that India has among the worst levels of gender wage disparity, with a gap of 30 per cent. There were further levels of inequality among women, as they formed 60 per cent of the lowest paid wage labour, and a mere 15 per cent of the highest wage-earners. The country has one of the lowest female labour force participation (FLFP) rates (typically measured as the share of women that are employed or seeking work as a share of the working-age female population) at a mere 33 per cent (Gonzalez et al., 2015). ${ }^{2}$ Thomas (2012) points to the large-scale withdrawal of women from the labour force and draws a parallel to Amartya Sen's (1992) 
thesis of "missing women" in the development literature in relation to the low female-male ratio in the population as a resultant of bias against the female child. Such bias is persistently evident in the continuing skewed sex ratio (against girls) showing increasing son preference, with neglect of daughters being prevalent in many Indian states (Mitra, 2014), and continuing manifestation of male bias in the Indian economy and society. In addition, Batliwala and Dhanraj (2007) contend that the neo-liberal agenda allows women to contribute economically to their household and also participate in and facilitate local politics and development schemes; nevertheless, they do not challenge the paradigm of gender bias.

Despite the closing gender gap in voter turnout, women are underrepresented in the lower house of the Parliament, the Lok Sabha (see Lal et al., 2015). Although amendments such as the Women's Reservation Bill have increased women's visibility in the public sphere, hostility towards this bill and the lack of women in these roles highlight the dearth of gender equality in India (Sabanna, 2016). Struggles specifically for women's rights took place throughout the 1970s, with demonstrations across the nation calling for a range of political attention to issues such as women's labour rights within wider agricultural strikes, violence towards women and labour market exclusion. Labour unions have and continue to create advances in women's and familial rights in the labour market, such as maternity benefits and equal pay; however, these alterations to law have also affected women, with organisations using such policies as a reason to disregard women in the recruitment process (Rohini, 1991).

Violence against women in both private and public spheres has gained much attention in India and it reveals gender discrimination (Kishwar, 1999; Basu, 2005). High incidences of rape, acid attacks, caste-based gender violence and honour killings have been met with shock on the global stage and demonstrations and protests across India - the 2012 Delhi gang rape case being a pertinent example (BBC Asia, 2012). This public misogyny has put women at constant risk of attack (Bhattacharyya, 2016), even in states with high Gender Development Indexes, such as Kerala. (Kerala nevertheless recorded 910 rapes from January to July in 2016 [State Crime Records Bureau, 2016], with this figure likely being more when taking into account potential unreported rapes.) Despite the country introducing legislation and numerous policies to enhance gender equality, patriarchal norms have relegated women to secondary status within the private and public sphere, which has hindered and still hinders progress towards gender equality and female empowerment, particularly in relation to India's Sustainable Development Goals (SDGs).

Women's status as a signifier of development and progress was brought out in studies during the 1980s and continues today. Dyson and Moore (1983) posit a positive relationship between female autonomy and demographic indicators, as they find more female autonomy in the south, due to demographic regimes based on kinship structures, property rights, norms of sexuality and dowry practices. This higher status of the south Indian woman has been well cited in the case of the southern Indian state of Kerala. Indeed the state has received much attention in development debates because of its human and social capital indicators, such 
as literacy, robust public policy in relation to health and education services. Its history of social mobilisation and its reputation as a vibrant civil society with well-developed human capital has made it a unique model of development (Parayil, 2000; Tornquist, 2000), particularly in terms of capacity building, human capabilities, citizenry and public action (Sen and Dreze, 1996; Heller, 2001; Tharamangalam, 2006; Ravi Raman, 2010; Bhagwati and Panagariya, 2013). Kerala's tradition of the matrilineal system, social reforms, high literacy and higher educational levels has, of course, contributed both to women's well-being and to higher levels of the Gender Development Index, although their ramifications for women's autonomy has come under scrutiny (Saradamoni, 1999; Kodoth and Eapen, 2005; Devika, 2009; Arun, 2012). Aspects of women's autonomy in relation to social, economic and political participation within the Kerala model will be discussed in this chapter, with implications for understanding gender capital.

\section{Locating the "Kerala model" of development}

The state of Kerala is a coastal state, with one of the largest density rates in the country. According to the 2011 census, Kerala occupied 1.27 per cent of the country's total area but had 2.76 per cent of its total population (Government of Kerala GoK, 2015). Kerala has always had an impressive demographic record in indicators of life expectancy at birth, Infant Mortality Rate (IMR) and literacy rates for both men and women. The higher literacy rates in Kerala is manifested through the gender parity achieved in enrolment within both primary and secondary schools. In fact, girls outnumbered boys in terms of enrolment in higher secondary education (with a rate of 52.73 per cent). The health indicators in Kerala are highly favourable to women in terms of life expectancy at birth of women at 76.9 years, the highest in India, where the national average at 67.7 years. Further the Maternal Mortality Rate for India for 2010-12 was 178 per 1,000,000 live births, while that for Kerala is much lower at 66 per 1,000,000 live births. Regarding women, it has a favourable gender ratio, with a ratio of 1084 for every 1000 males (see Table 3.1).

Kerala's female-male ratio is 1084 females for every 1000 males, while for India this is only 940 (GoK, 2015); along with Puducherry, Kerala is the only other state where this is more than 1000 . This particularly contrasts with many northern states, where the union territory of Chandigarh is the lowest with only 818 females for every 1000 males; for Punjab, it is 893, while Delhi, the capital city, has only 866 women for every 1000 men. Although such indicators of higher levels of HDI are indeed a pointer for higher quality of life, trends in the child sex ratio in Kerala is causing some concern. The child sex ratio is generally acknowledged as an important single indicator of gender bias in India and is often attributed to lack of education and poverty. In many ways, this relates to Amartya Sen's (1992) thesis on the "missing women and girls" across India due to gender bias, and reflected in the unequal levels of child sex ratio. According to Census of India 2011, the child sex ratio (0-6 years) in India is 918 girls for every 1000 boys, and 964 for Kerala, both of these are unfavourable to girls. In many states, 
Table 3.1 Social Indicators in Kerala and India

\begin{tabular}{lcc}
\hline Indicators & India & Kerala \\
\hline Male Life Expectancy (years) & 62.60 & 71.40 \\
Female Life Expectancy (years) & 64.20 & 76.30 \\
Total Life Expectancy (years) & 63.5 & 74.00 \\
Birth Rate (per 1000) & 22.8 & 14.6 \\
Death Rate (per 1000) & 7.40 & 6.60 \\
Infant Mortality Rate (IMR) (per 1000) & 44.0 & 6.70 \\
Maternal Mortality Rate (per 100,000 live births) & 301 & 40 \\
Total Fertility Rate & 2.90 & 1.70 \\
Male Literacy Rate (\%) (2011) & 82.14 & 96.0 \\
Female Literacy Rate (\%) (2011) & 65.46 & 93.9 \\
Total Literacy Rate (\%) (2011) & 74.04 & 92 \\
Female Child Sex Ratio (per 1000) & 918 & 964 \\
Female Adult Sex Ratio (per 1000) & 940 & 1084 \\
\hline
\end{tabular}

Source: GoK (2015)

state schemes such as the Beti Bachao, Beti Padhao (Save the girl child, Educate the girl child) are in place to improve the efficiency of welfare services meant for the girl child in India. However, policy makers have been alarmed by the current trends in Kerala's child sex ratio, as this is unfavourable to girls and has caught the attention of UNICEF (The Times of India, 2012, Online). Before expanding on emerging aspects of gender inequalities in the state, it is relevant to examine how the relative lack of gender bias in Kerala is rooted in its historical, social and cultural practices - notably the system of matriliny, as discussed below.

\section{The political economy of the Kerala model}

Kerala is often deemed a juxtaposition or even fusion of modernism and conservatism (Raj, 1970), illustrative of how its history - in terms of political, geographical, historical, economic and social aspects - can help locate the "Kerala model" of development. For example, Puthenkalam (1977) notes how Kerala's geography partially explains its social structure and features whereby extensive foreign contact over centuries (in many ways akin to present-day globalisation) has considerably influenced the state's social structure. Kerala's record of social development has been well documented, with its origins well rooted in history and culture. The various political and economic developments in Kerala - for example, the spread of Western education, the rise of socio-religious movements and the creation of public infrastructure - significantly changed the social and cultural life in the three major regions: Travancore, (southern state) Malabar (northern state) and Cochin (central state). Many social movements for gaining social equality and justice in early twentieth century Kerala, particularly for those social groups that endured restrictive public access practices, are notable for their contribution to the social transformation of Kerala's social fabric. These included the Ayyankali (rights of dalits to walk on public roads); Vaikom Satyagraha (1924-1925) 
for freedom of movement on public roads; Shri Narayana (guru's teaching and the formation of the "Shri Narayana Dharma Paripalana Yogam" [SNDP]); and the Guruvayoor Satyagraha (for right to enter into temples). Further, a greater level of democratisation and progressive trends enabled, non-dominant groups (e.g. Christians had gained firm standing in the sircar [government] lands through trade and commerce, while many lower castes also benefited from socioeconomic changes). More specifically, these changes included a rise in agricultural prices and extended transport services by the late nineteenth century, which led to the opening up of plantations and other manufacturing industries like coir (coconut husk) during British rule (Varghese, 1970). Trade flourished as the region was linked to the world market with the emergence of railways and the sea trade, again exhibiting trends of a global economy. All this further increased the area under cash crops, especially in Travancore (Varghese, 1970), leading to rapid commercialisation. Subsequently, credit and banking institutions were developed, known as kuries and chitties (Tharakan, 1998). ${ }^{3}$

Differences in the pace and intensity of development influenced social and economic development in various ways and thus contributed to the differences among these regions (Varghese, 1970). With the increased immigration of Brahmins into Kerala by the eleventh century, the Nair (upper caste) chieftains were bestowed with the status of kshathriyas (rulers) in an attempt to introduce the chathurvarna (four-caste) system (Varghese, 1970). Nevertheless, the widespread practices of the matrilineal joint family helped preserve property rights (Jeffrey, 1976) and even transformed systems of land, caste relations and business trading. ${ }^{4}$ Overall, patrilineal and matrilineal systems of inheritance and family organisation have co-existed in Kerala, with lower castes emulating practices from other social systems (Raj, 1970). Anthropological studies such as Dube (1997) note how such matrilineal kinship practices have had a significant bearing on gender and social identities for women, as is seen below.

\section{Matriliny in practice: caste, kinship and class in Kerala society}

Changes because of agrarian and socio-religious movements generally have bearing on caste and social relations. As Beteille (1965) points out, caste alone is insignificant in understanding the Indian economy, however caste practices intersect with many other factors such as kinship and class, and determine the nature of gender relations in the household and wider society. Of particular interest here are changes to the matrilineal system practised in Kerala that affect women in general but also specifically property ownership and gender roles. Much interest has been generated on caste practices among the Nair communities of Kerala (e.g. Menon, 1978; Jeffrey, 1976). The Nair form of matriliny is seen as the standard; for example, Fawcett believes Nairs to be 'the best, the fullest, the most complete existing example of matriliny' (1985:186).

The unique structure of matrilineal families and their practices through inheritance, marriage and the household determine social and gender roles (Saradamoni, 
1999). The tharavad, or Nair household, is seen as a typical institution that signifies power relations, ${ }^{5}$ division of gendered and social roles, and decision-making. Debates on such kinship practices premised on Eurocentric notions of family and patrilineal systems culminated in legislation to reform matrilineal kinship practices (see Fuller, 1976), which rendered such matrilineal practices as deviant from this perspective. In her Matriliny Transformed work, Saradamoni (1994) drew upon The Report of the Travancore Marumakkathayam Committee (GoT, 1908) which looked at aspects of the system in relation to marriage practices related to sambandham, succession, the role of karanavar and anandaraven, and partition, all of which had an important bearing on gender roles, autonomy and property rights. She states how important it is to bear in mind that such changes were initially based on evidence from men rather than women, as the latter were reluctant to provide evidence to the committee. The committee's conclusion - 'the fact is that Nair ladies are generally under the control of their male relations and the evidence of the males may be taken as intended to protect the best interests of the females also' (GoT, 1908, par 9, cited in Saradamoni, 1999, p 87) - perhaps related to this. In their entirety, social, economic and political changes over the nineteenth and early twentieth century have indeed transformed Nair women's identity, security and autonomy (Jeffrey, 1976; Saradamoni, 1999), leading to the gradual adoption of patriarchal practices, forever changing women's status within the household. Besides, family structures and ideologies upheld dominant norms of femininity, and domesticity prevailed (Kodoth and Eapen, 2005). Thus matrilineal practices may not indicate a fully egalitarian society in terms of gender roles and autonomy (Lepowsky, 1993). Early twentieth-century Kerala witnessed changes to the joint-family system, changing demographic profile and the rise of agrarian capitalistic tendencies (see Varghese, 1970). These social and economic developments transformed land relationships and matrilineal kinship practices, with implications for the social and economic structures in the state - both in the past and in contemporary Kerala society.

\section{The impact of the Kerala model on human capabilities and development}

The primary "woman's agency" of female literacy has contributed much to exemplary social development in this context (and indeed many others), so gender is clearly an important resource or agency in the Kerala model of development. Sen (1992) charts three key factors in Kerala's progress in health and education. Firstly, the relative autonomy of the government in two of Kerala's three sub-regions (Cochin and Travancore) during the colonial period allowed more spending on health and education. Secondly, women were allowed equal access to these services because of women's social position; this largely came through practices within the matrilineal system of descent, which accorded equal positions to women and thus allowed their access to health and education services. Thirdly, a surge of social and religious reform movements influenced the social structure in the nineteenth and twentieth centuries. This allowed excluded castes 
to be transformed through the spread of social benefits down the caste hierarchy, indicating a high level of democratisation. The regime of the native rulers also helped to promote public health and education by creating awareness as well as infrastructure; for example, large support was provided to promoting ayurveda (traditional medicinal systems). In Travancore, institutions like the 1854-formed London Missionary Society (LMS) got grant-in-aid, which helped to promote public health in the form of treatment, vaccinations and public sanitation measures like sewage facilities (Sen, 1992). The region of Cochin, with an extensive decentralised system, also developed a public health system. The development of infrastructural facilities and a network of health institutions and Primary Health Centres $^{6}$ (PHC), along with a significant allocation of the governmental budget for education and health development, (Paniker and Soman, 1984) were other factors in achieving a commendable record of social development in the state. Kerala's low fertility rates were attributed to higher literacy levels for men and women, the latter particularly resulting from a strong emphasis on female education - an outcome of the traditionally followed matriarchal social system. Thus, the unique position of women, accorded by society's matrilineal system of descent and newly emerged social and religious reform movements, accelerated the democratisation process from previous rigid social stratification (Tharakan, 1998). Furthermore, women played an important role in public health by creating awareness of vaccinations and medical care, and by promoting nursing as a practice in local hospitals (Sen, 1992). Similarly, the Christian missionaries (Roman and Protestant) established modern schools, as the state did later. Other caste-based movements, like Sree Narayana Dharma Parpalana (SNDP) - an Ezhava social reform movement inspired by Sreenarayana Guru (a nineteenth-century social reformer), also contributed to greater social awareness (Tharakan, 1998).

Agrarian movements were crucial for change in Kerala, as organised peasant and agricultural workers' movements brought such during the nineteenth and early twentieth century. Kerala is one of the only two states (the other being West Bengal) in India to have implemented effective land reforms in the post-independence period. These land reforms were crucial in transforming agrarian relations in Kerala (Raj and Tharakan, 1983), and Ramachandran (1997) says land reform measures in Kerala had three major components. The first involved security of tenure for tenants, rent arrears being cancelled and the government taking away the rights of janmi (landlords) for land to be given to the tiller. Secondly, those with kudikiddappu (homestead land) were given ownership rights. Thirdly was a restriction on land ownership, so land identified as surplus was distributed to the landless. Redistribution strategies like land reforms are commendable, but they also on occasion complicated new relations of exploitation and subordination in agriculture, particularly in farm employment and business interests (Tharakan, 1998).

As noted earlier, differences in development policies have had important and identifiable consequences for the present rate and pattern of social and economic change in Kerala. Much has been written about the declining contribution of Kerala's primary sector and of contributions from the secondary sector being stagnant 
but compensated only by growth in the tertiary sector (Zachariah and Irudayarajan, 2007). Kerala's current growth figures show a positive trend in line with national trends. The per capita Gross State Domestic Product at constant (2011-12) prices in 2014-15 for the state was ₹ 127166 , recording a growth rate of 6.15 per cent in 2014-15. In terms of sectoral distribution, during 2014-15, the contribution from primary, secondary and tertiary sectors to the Gross State Value Added (GSVA) at constant prices (2011-12) was 12.15 per cent, 25.11 per cent and 62.74 per cent respectively. Recent studies such as Bhagwati and Panagariya's (2013) refute the claim that the state achieved such health and education outcomes through activist state intervention, as data based on public health expenditure from 1991-1992 to 2010-2011 shows that this expenditure does not exceed 1 per cent of GSDP. On the contrary, it shows that private expenditure on health and education is quite high, which for the authors also casts doubt on the conventional claim of state-led success during post-independence.

Being largely an agrarian economy, Kerala's dominant cultivation type is smallholder crop cultivation that is a consequence of the land reforms and changes in social structure. However with neo-liberal policies and changes in relation to crop prices, concerns about distress in the agrarian sector and ensuing farmers' suicides have been subject to widespread discussion. In particular, in regions where farmers have taken up the cultivation of export-oriented high-value crops, ${ }^{7}$ the volatility of crop prices has brought declines in farming income, adversely affecting the livelihood of the agrarian population and creating conditions of distress (Nair and Menon, 2007). Other factors such as declining public investment in agriculture, slow growth of output, low rise in the price of agricultural commodities compared with input prices and falling farm incomes have also aggravated lower growth in the agrarian sector (Arun, 2012).

Discussions in the 1990s centred not only on the association between Kerala's achievements and low economic growth but also on how continued economic crises pose many challenges for such a growth trajectory, questioning its sustainability (Frankie and Chasim, 1994; Veron, 2001). Overall, mounting fiscal deficit in the 1990s threatened the public gains from the widely acclaimed Kerala model, and it even suggested crises for the Kerala model (Oommen, 1993). The legacy of Kerala's left-wing politics is best described in Tornquist and Tharakan's (1996, p. 2042) words:

While the leftist politics may have been necessary for progressive post-colonial change in general and democratisation and popular development in particular, its dynamics bred interest and institutional interests which worked against further development, and which began to undermine the hitherto propelling force-broadly based popular organisations.

Recent attention to the conundrum of the Kerala society (see BBC, 2010) shows how its record of literacy has become a liability with its high levels of unemployment, an over-extended state and a politicized society, so it is facing a secondgeneration problem of growth. Since the 1980s, higher unionisation and powerful 


\section{Situating gender capital in Kerala}

bargaining for higher wages, together with resistance to technological change, have forced enterprises to migrate to other states, leading to unemployment and the emigration of people from both the state and the country. Kerala has had a long history of links with the global society and economy, both historically and in contemporary times, and it has exhibited new forms of capitalism through the changing international division of labour. In particular, remittances from migrants outside the region, labelled as "money order economy" or "Gulf Money", have indeed contributed to the growth of the tertiary sector and to increased consumption expenditure in the state (Zachariah and Irudayarajan, 2012). Kerala, like other states, has embarked on an informatisation strategy by capitalizing on both the high level of human capabilities and the conducive policy environment - for example, the State Electronics Technology Park, otherwise known as "Technopark". Such institutions reflect the internalisation of production that has altered labour markets, social relations and development planning, particularly in the context of Kerala. This is partly due to shifts away from a state-centred approach to development, with increased presence of market forces that alter global-local as well as gendered relations.

\section{Social and public policy interventions}

For many decades different social movements and a leftist influence in Kerala have been successful in implementing support-led growth policies that improved social justice, such as land reforms, public distribution measures, robust labour unions, public services (e.g. health and education) and, recently, decentralisation since the late 1990s. The Human Development Report 2010 ranked India 119 out of 169 countries based on the Multidimensional Poverty Index (MPI), with a poverty figure of 41.06 per cent (based on a purchasing power parity [PPP] of $\$ 1.25$ per day). The lower poverty rates in relation to India are well evidenced. For example, rates of rural poverty is 7.3 per cent in Kerala compared to 30.9 per cent in India, while the rates of urban poverty is 15.3 per cent in Kerala, compared to 26.4 per cent for the whole of India (see GoK, 2015). However such achievements in poverty reduction, health and education, as Bhagwati and Pangariya (2013) claim, are associated with high, not low, per capita incomes and expenditures. In many ways, Kerala's growth experience has been cited to show a different trajectory from other developing contexts with successes of the masses being institutionalised and made part of the rational-legal order (Mannathukkaren, 2010).

The enactment of the Kerala Panchayat ${ }^{8}$ Raj Act and the Kerala Municipality Act in 1994 initiated steps towards decentralisation in Kerala, making it the most fiscally decentralised state in India and second only to Colombia in the developing world (Heller, 2001). The Kerala Panchayati Raj ${ }^{9}$ Act 1994 devolved authority and responsibility to the local self-government institutions (LSGIs), particularly in the area of poverty eradication. Heller et al. (2007) posit the democratic decentralisation experience as a move from the constitution of public spheres to the institutionalisation of participatory publics, which has resulted in the transfer of powers, functions, institutions and human resources to LSGIs, devolved funds and 
restructured the relevant state level legislations (GOK, 2015). These initiatives have led to the development of decentralised institutions that are participatory in nature; the prime example of effective decentralisation is the Kudumbashree programme, which involves working with local institutions to plan and implement anti-poverty programmes. The Kudumbashree system works through networks of community-based organisations and plays an important role as a nodal agency for anti-poverty programmes of the central, state and local governments, thus serving as a strong conduit of state programmes ${ }^{10}$ (John, 2009).

Since both conceptually and operationally the Kudumbashree network is linked to local government institutions, 10 per cent of anti-poverty sub-plans is spent on women's projects through micro-enterprises and minimum needs assets (John, 2009). Kudumbashree is recognised as one of the largest women's movement, with a membership of 390,097, where households identified as below the poverty line have been brought under the community based organisations (CBOs). Presently there are 258,000 Neighbourhood Groups (NHG), 19,854 Area Development Societies (ADSs) and 1,073 Community Development Societies (CDSs) - operating in all 978 grama panchayats, 60 municipalities and five corporations (Kudumbashree, Online).

The phenomenal growth in savings and credit societies highlights the potential for the poor to accumulate savings and assets through community approaches. The self-help model acts as a communal body with savings, credit, training and advocacy functions leading to the formation of micro-enterprises and economic empowerment (Arun et al., 2007). Studies on the NREGA rural employment guarantee scheme in various contexts have shown that women's participation in this programme is due to the provision of equal, non-discriminatory wages (Khera and Nayak, 2009). Yet such public intervention programmes targeting women are riddled with politicisation for vested interests, the operation of gender norm and power politics at the local level, overloading work and the increased indebtedness of households along with low sustainability in micro-enterprises (John, 2009; Shihabudheen, 2013).

\section{Why gender capital matters in Kerala: from rhetoric, representation to transformation}

Kerala is no different from other regions of India regarding women and paradoxes, but its unique tradition of the matrilineal system, social reforms and educational levels have contributed much to women's well-being and to leading commendable levels of the Gender Development Index. While women have long been a central concern of state (and national) policies on population, human reproduction and welfare (see Yuval-Davis and Anthias, 1989), their overall position vis-à-vis development and growth processes has been ambiguous. The Kerala model also exhibits women's unequal participation and gains from such an acclaimed model. Some of these are outlined below.

Firstly, recent studies argue that there has been a steady de-feminisation of the labour force, most blatantly manifested in a declining proportion of females 


\section{Situating gender capital in Kerala}

in Kerala's labour force (Abraham, 2013). Such a trend is associated with the increased domestication of women and the quest for social status and social mobility. In terms of labour force participation, the 2001 census shows that male work participation in Kerala increased to 50.2 per cent from 47.6 in 1991, and evidence based on various National Sample Survey (NSS) reports show women's declining work participation (see Table 3.2), as defined by Usual Principal Status (UPS). The Usual Principal and Subsidiary Status (UPSS) shows a similar decline.

Thus, in a comparative framework, the female capital (in terms of higher levels of human and cultural capital) in Kerala is much endowed compared to women elsewhere in India or in other similar contexts. This is, however, a different scenario in economic and political capital. As per the 68th Round of NSS there is an evident gap between male and female labour force participation, for example, the female LPR in Kerala is 35.4 and the male is 82.4 , which is much lower than other countries in South Asia (GoK, 2015). Similarly, the Work Participation Rate (WPR) of women in Kerala is lower than that of many states in India as well as the all India average. According to Census 2011, the average WPR is 25.21 per cent in India and that of Kerala is only 18.23 per cent. In terms of sectoral distribution of employment, 31.9 per cent of women are engaged in agriculture, 30.4 per cent in industry, and 37.7 per cent engaged in the service sector (GoK, 2015). The LPR indicates the proportion of the population that is economically active, including the employed as well as those unemployed but actively seeking jobs.

The proportion of the population that is employed is denoted by the WPR. This accounts for the lower participation rate of women in an economy - especially in agriculture, which is an important form of livelihood. Agriculture accounts for about 60 per cent of female employment in rural areas, though in Kerala the absolute numbers employed have been declining, partly because of a changing cropping pattern and withdrawal of women into domesticity (Patrick, 2005). Whilst women are engaged in agricultural work and in traditional industries, such as in cashew and beedi factories, there is significant gender inequality wages and remuneration seen through the gender attainment index of wage rates, calculated by female wage rate/male wage rate. The index for daily wage rates in agricultural activities such as sowing, weeding and transplanting is lower in Kerala (and Andhra Pradesh) with an index of 0.70 compared to the all India figure of

Table 3.2 Work Participation Rates by Gender, 1983-2011

\begin{tabular}{|c|c|c|c|c|c|c|c|c|}
\hline \multirow[t]{2}{*}{ Year } & \multicolumn{2}{|c|}{ Rural Male } & \multicolumn{2}{|c|}{ Rural Female } & \multicolumn{2}{|c|}{ Urban Male } & \multicolumn{2}{|c|}{ Urban Female } \\
\hline & $U P S$ & UPSS & $U P S$ & UPSS & $U P S$ & UPSS & $U P S$ & UPSS \\
\hline 1983 & 54 & 55.5 & 25.2 & 34.2 & 53.1 & 54 & 12.9 & 15.9 \\
\hline 1993-1994 & 54.9 & 56.1 & 23.7 & 33.1 & 54.2 & 54.3 & 13.2 & 16.5 \\
\hline 2004-2005 & 54.6 & 55.5 & 25 & 33.3 & 56.6 & 57.1 & 14.9 & 17.8 \\
\hline 2009-2010 & 54.8 & 55.6 & 20.8 & 26.5 & 55.6 & 55.9 & 12.8 & 14.6 \\
\hline $2011-2012$ & 54.7 & 55.3 & 18.1 & 25.3 & 56 & 56.3 & 13.4 & 15.5 \\
\hline
\end{tabular}

Source: NSS Reports - Census of India (2011); GOK (2015) 
0.81, or 0.82 for Bihar and 0.73 for Tamilnadu (GoK, 2015). However, it must be noted that while the wage rates of women in Kerala is higher than that in other states and the all India average, it is much lower than that of males. Thus while the women in the informal sector of Kerala are much better off compared to women in other states, their economic earnings are much lower compared to their men. Wage disparities in casual work and the construction sector are also gender influenced (GOK, 2015). Overall, then, shifts in cropping patterns and demand for male labour, unequal wages for women and decline in employment in cottage industries reflect both the gender-related nature of the labour market (Eapen, 2004; Patrick, 2005; Arun, 2012) and the intersection of class and caste in shaping women's work (Lindberg, 2001). The neo-liberal reforms associated with economic liberalisation since the 1990s have indeed affected Kerala's agrarian economy, intensifying gender relations (see Gangadharan, 2010; Arun, 2012). While evidence of the increased domestication of women prevails, those who enter and remain in the labour market are those from vulnerable households and they do so as marginalised informal workers, thus feminising the most precarious forms of labour (Abraham, 2013). In addition, the education sector also exhibits gendered inequalities. Whilst there are higher levels of girls' enrolment across schools and across degree and post-graduate courses, girls constitute only 40.23 per cent of the total enrolled students in engineering colleges and 32.76 per cent in polytechnics. Thus gender disparities in engineering and technical subjects are evident, which is a concern amongst gender researchers (see Howcroft and Richardson, 2009), showing imbalances in gender representation within scientific and technical fields.

Secondly, the "exclusionary" effects of the model (Kurien, 1995; Steur, 2011) exhibit gendered gaps in social development (Arun, 2012). Firstly, disparities among geographical regions is marked with lower literacy rates of both males and females, and overall literacy is much below the state average, though in seven districts it is higher than the average (see GoK, 2015). Secondly, despite many development programmes, the Scheduled Castes and Scheduled Tribes (SCs and STs, referred to as Dalits and Adivasis respectively) lag behind the general population in terms of social and health indicators. Although in Kerala their situation is generally much better compared to their counterparts elsewhere in India, large levels of inequalities still exist in this state. Also, the literacy rates of STs and SCs are lower in all districts, especially for women. Thirdly, the much-praised favourable sex ratio has always been unfavourable to women in the economically backward districts of Idukki and Waynad, which have the highest proportion of STs. In a follow-up case study of a village in central Kerala, most state development programmes have barely benefited SC and ST groups, which Kurien (1995) terms the "outliers" and "margins of society". Notwithstanding Kerala's record of successful land reforms and pioneering decentralisation initiatives, Kerala's marginalised communities have yet to fight for a decent livelihood, through an alternative front, quite removed from the established Right-Left domains in the state (Ravi Raman, 2002), thus exhibiting a paradox within a paradox (Chandran, 2012). Such deviations from the hegemonic narrative show how the processes, 
causes and consequences of deprivation and conflict must be situated in the context of the specific configuration of the political economy, geography and history of the contexts in which they exist.

Thirdly, the political participation and thus representation of women in governance structures has received some attention (John, 2007). In terms of political capital, we see that the higher level of female capital in Kerala is not reflected in the public decision-making bodies such as the central and state legislative bodies. For example, whilst in 2014, women form 11.5 per cent of the Lok Sabha (Lower House of the Indian Parliament), only 5 per cent of female representation is from Kerala (GoK, 2015). Similarly, figures for the 2011 state level show there is only 5 per cent of female representation in the Kerala legislature, a figure that is unchanged from 2006 (GoK, 2015). Describing women's limited access to political power as a sub-paradox of the gender paradox, Devika and Thampi's $(2010 ; 2011)$ observations of women in decentralised governance roles show that while the sphere of local governance offers many opportunities for social mobility, it also emphasises a space for deploying altruistic feminine capacities alongside a reiteration of conservative family norms. Further, as seen earlier in this chapter, women's participation in formal politics is low, with the 2011 Kerala assembly having seven women compared with 133 male legislators. Given that the "empowered" Malayalee women have been absent from participation in formal political roles, their full citizenship within an acclaimed progressive context remains questionable. Efforts to address gender concerns through self-help groups under the decentralisation initiatives were more successful in addressing the practical needs of women rather than their strategic needs or in challenging patriarchal norms, leading to new forms of domination (Jose and Nair, 2011). In many cases, women's participation has been more functionalist - as a conduit for implementation rather than their own empowerment.

Finally, violence against women is also rising in the state. Figures from the state crime records bureau show that the total reported cases of crime against women for the year 2014 is 10,690 (GoK, 2015). Out of this, "cruelty by husband/relatives" still constitutes a major component in crime against women. As per data from the National Crime Records Bureau (NCRB), Kerala is a state where "Rate of Total Cognizable Crimes" (incidence of crime per one lakh female population) is much higher than the national level (NCRB, 2015). Shreekumar (2007) portrays a dystopic vision of Kerala, with an increasing prevalence of sexual crimes against women juxtaposed alongside narratives of sex rackets involving individual (younger) women. Here, the younger women who exercise choice and agency have been endangered. As gender ideologies operate on social norms, women are framed within discourses of sexuality and domesticity (see Chapter 8).

Women's status in Kerala's economy and society has been a point of much discussion (e.g. Jeffrey, 1993), particularly regarding the matrilineal system of inheritance. However, evidence shows that women's control of assets is largely limited to nominal ownership of the house rather than ownership of land, or their control (Arun, 2012; Kodoth and Eapen, 2005). Furthermore, a combination of factors such as dowry practices, changes in familial practices and the increased 
sale of cultivable land have led to the erosion both of women's rights and of their control of economic assets (Lindberg, 2001; Kodoth, 2008; Arun, 2012). A close scrutiny of labour force participation, trends in violence against women, and cultural practices, including patriarchal tendencies, shows how these have unsettling consequences for women's position in the society (Eapen, 2004; Mitra and Singh, 2007; Menon, 2009) and their high economic dependency in later life, particularly for widows (Mohindra et al., 2012).

Nevertheless, other evidence has shown that the gender gap in employment within households is linked with inverse effect on marital violence (Agarwal and Panda, 2007). To clarify, where the woman has a higher employment status than her husband, the incidence of physical violence is twice that where she has the same or a lower employment status. However, women's property ownership reduces violence against them, highlighting the need for women's ownership of resources (Agarwal and Panda, 2007). Thus the position of women within Kerala society is evidently riddled with contradictions. Indicators of favourable social empowerment based on high education levels, positive development indicators such as mortality and fertility rates, and a favourable sex ratio exist alongside women's persistent economic marginalisation, invisibility in formal politics and suffering through rising violence against them.

Therefore, representation of the Kerala woman itself is "political", and any "politics of representation" should revolve around pragmatic constructions that explore wider power relations (see Hall, 1997). As seen in Chapter 2, the Bourdieusian framework (1986) helps to operationalize the ideas of habitus, field and forms of capital, and it makes it possible to consider women as the individual (through habitus), specifically through the fields of work and households (fields). Gender as capital as a useful tool for understanding contemporary gender practices draws from scholarship on Bourdieusian feminists, such as McCall (1992, p. 843) notes on how notions of gendered capital can be drawn from Bourdieu's formulation of embodied cultural capital.

\section{Conclusion}

As seen, women's gendered capital often operates within limits (see, for example, McCall, 1992; Skeggs, 1999; Huppatz, 2009). Huppatz's (2009) making the distinction between female and feminine capital useful as it conflates the concepts of "femininity" and "female" so that femininity is generalized as a female condition. This notion of gender capital is useful as the Kerala woman is noted for her female capital through notions of autonomy, and it has been instrumental in achieving the Kerala model of development as a form of "human and cultural capital". Cultural beliefs, rites and practices are often pointers of gender relations in society, and scholars have noted female-oriented rites and rituaIs in Kerala (Gough, 1954; Puthenkalam, 1977), an indicator of valuing the feminine capital through cultural processes. While the Kerala female's capitals - especially her higher literacy rate and awareness of health and family welfare - have led to higher rates of social development, even with lower economic capital, the Kerala model has not come 
to accommodate her feminine capital, rather hinging on the domestication of such capital. In fact, legislative interventions that were intended to reform matriliny actually pushed women into dependant, protected positions, even when women's presence was active in the field of education, journalism, legal and social services throughout the twentieth century (Saradamoni, 1999). To some extent, women have capitalized on their female and feminine capital by entering into economic employment to some extent. While the remarkable historic gains of women in Kerala must not be underestimated, there are emerging concerns about the changing roles of gender relations, as these have an important bearing on opportunities, power relations and outcomes, albeit among contradictions and paradoxes.

\section{Notes}

1 According to the IMF, the 1990s saw India initiating a neo-liberal, market liberalisation ideology whereby it liberalised trade, devalued national currency, increased privatisation and reduced public spending, all of which saw growth rates of 7.5 per cent in the late 2000s and rapid growth in services such as Information Technology. Recent policy measures have stressed employment creation in the manufacturing sector, which accounts for 61 per cent of the country's GDP but employs less than 4 per cent of the population (Harvard Kennedy School Review, 2016).

2 There is much evidence for there being a persistently low and even declining female labour force (see Bhalla and Kaur, 2011; Gonzalez et al., 2015). The main factors relate to husband's education, the middle-class effect and withdrawal of women from the labour market but also social norms and restrictions on women's rights to inheritance, property and work participation. However, Gonzalez et al. (2015) find that increased social spending and policy initiatives such as the National Rural Employment Guarantee Act (NREGA) enhance women's labour-force participation.

3 The difference in political alignments had a tremendous impact on the type of land tenure followed in Malabar, which was under British administration while Travancore, which remained a native state until 1947, and Cochin, which was in an intermediate position between these two regions (Varghese,1970). However, in Malabar lower castes did not gain much land ownership, though some of the moplahs (Muslims) and the Theeyas, who were strong in non-agricultural activities, acquired land. But the sthanam (temple) properties of the former ruling chiefs were exempted from partition laws, limiting the impact of these laws. Commercial penetration and the rise of capitalism were not only facilitated by the free transfers of land but also activities like trade and commerce by the Christians, Muslims and Theeyas (Tharakan, 1998).

4 For example, control of land was transferred to the Brahmins or chieftains as a token of allegiance or respect. Leasing of land on pattom (tenure) and other kinds of tenure to Christians, Muslims and Theeyas led to tenure practices such as kanom (meaning kannikka or respect) or kuzhikannom, which intended to convert wastelands to cultivation, and these benefited the Muslims and the Theeyas mainly in Malabar (Tharakan, 1998).

5 Its distinctive features include practices of the female line of descent (taivazhi), which assigned authority and power to the eldest female members; permited conjugal forms of relationship (sambhandam) within the same caste or higher caste, which could be dissolved on mutual consent, whereby husbands were often "visitors" and thus allowed sexual autonomy; kept all offsprings in and belonging to the tharavad; and bestowed the eldest maternal uncle as head of the household and with all economic and social responsibility, as fathers were given no paternal responsibility.

6 A PHC covers a population of 30,000 and caters to the health needs of the local population, especially in family planning and immunisation services. 
7 Increased volatility in crop prices, shortage of rainfall and increased incidence of drought had affected crop yields.

8 A panchayat refers to the local level of administrative unit.

9 The three-tier panchayati raj system comprises 999 gram panchayats at the village level, 152 block panchayats at the intermediate level and 14 zilla panchayats at the district level.

10 The Swarna Jayanti Shahari Rozgar Yojana (SJSRY), the central government's urban anti-poverty programme, and the National Rural Employment Guarantee Act (NREGA) are overseen by the Kudumbashree network.

\section{References}

Abraham, V. (2013). 'Missing labour or consistent “de-feminisation"?' Economic and Political Weekly, August 3, XLVIII(31), pp. 99-108.

Agarwal, B. and Panda, P. K. (2007). 'Toward freedom from domestic violence: The neglected obvious.' Journal of Human Development, 8(3), pp. 359-388.

Agarwal, B. (1994). A Field of One's Own: Gender and Land Rights in South Asia Cambridge: Cambridge University Press.

Arun, S. (2012). 'We are farmers too: Agrarian change and gendered livelihoods in Kerala, South India.' Journal of Gender Studies, 21(3), pp. 271-284.

Arun, S., Heeks, R. and Morgan, S. (2007). 'ICT initiatives, women and work: Rreproducing or changing inequalities.' In: Ghadially, R. (ed.), Urban Women in Changing India: A Reader, pp. 297-308. New Delhi: SAGE Publications.

Banerjee, N. (1998). 'Women's work and family strategies: A case study from Bankura.' West Bengal, Centre for Women's Development Studies, New Delhi.

Bardhan, K. (1993). 'Social class and gender in India: The structure of differences in the condition of women.' In: Clark, A. W. (ed.), Gender and Political Economy: Explorations of South Asian Systems, pp. 146-178. New Delhi; Oxford University Press.

Basu, S. (2005). Dowry and Inheritance: Issues in Contemporary Indian Feminism. Women Unlimited. New Delhi: Women Unlimited/Kali for Women.

Batliwala, S. and Dhanraj, D. (2007). 'Gender myths that instrumentalize women: A view from the Indian front line.' In Cornwall, A., Harrison, E. and Whitehead, A. (eds.), Feminisms: Contradictions, Contestations and Challenges in Development, pp. 21-34. London: Zed Books.

BBC. (2010). 'Conundrum of Kerala's struggling economy.' March 17 [Accessed July 2016] Available at: <http://news.bbc.co.uk/1/hi/world/south_asia/8546952.stm.

BBC Asia. (2012). 'Protests in India after Delhi gang-rape victim dies.' 29 December 2012. [Online] [Accessed on 23 September 2016] Available at: <www.bbc.co.uk/news/ world-asia-india-20863707>.

Beteille, A. (1965). Caste, Class and Power: Changing Patterns of Stratification in a Tanjore Village. London: University of California Press.

Bhagwati, J. and Panagariya, A. (2013). India's Tryst With Destiney: Debunking Myths that Undermine Progress and Addressing New Challenges. New Delhi: HarperCollins India.

Bhalla, S. and Kaur, R. (2011). 'Labour force participation of women in India: Some facts, some queries.' LSE Asia Research Center: Working Paper No. 40.

Bhattacharyya, R. (2016). 'Street violence against women in India: Mapping prevention strategies.' Asian Social Work and Policy Review (early view - Online version of record published before inclusion in an issue). $<$ http://onlinelibrary.wiley.com/journal/10.1111/ (ISSN)1753-1411/earlyview>. 
Bourdieu, P. (1986). 'The forms of capital.' In: Richardson, J. (ed.), Handbook of Theory and Research for the Sociology of Education, pp. 241-258. New York: Greenwood Press.

Bulbeck, C. (1998). Re-Orienting Western Feminisms: Women's Diversity in a Postcolonial World. Cambridge: Cambridge University Press.

Chandran, D. (2012). 'A paradox within a paradox: Emerging signs of change in the unappealing tribal scenario in Kerala, India.' Developing Country Studies, 2(6), pp. 1-11.

Cornwall, A., Harrison, E. and Whitehead, A. (2007). Feminisms in Development: Contradictions, Contestations and Challenges. London: Zed Books.

Den Uyle, M. (2000) 'Kinship and gender identity: Some notes on Marumakkathayam in Kerala.' In: Böck, M. and Rao, A. (eds.), Culture, Creation, and Procreation: Concepts of Kinship in South Asian Practice, pp. 177-198. New York: Berghahn Books.

Devika, J. (2009). 'Bodies gone awry: The abjection of sexuality in development discourse in contemporary Kerala.' Indian Journal of Gender Studies, 16(1), pp. 21-46. doi: 10.1177/097152150801600102.

Devika, J. and Thampi, B. V. (2010). 'Empowerment or politicization? The limits of gender inclusiveness of Kerala's political decentralisation'. In: Ravi Raman, K. (ed.), Development, Democracy, and the State: Critiquing the Kerala Model of Development, pp. 177-191. London: Routledge.

Devika, J. and Thampi, B. V. (2011). 'Mobility towards work and politics for women in Kerala state, India: A view from the histories of gender and space.' Modern Asian Studies, 45(5), pp. 1147-1175.

Dreze, J. and Sen, A. (1996). India: Economic Development and Social Opportunity. Oxford: Oxford University Press.

Dube, L. (1997). Women and Kinship: Comparative Perspectives on Gender in South and South-East Asia. New York: United Nations University Press.

Dyson, T. and Moore, M. (1983). 'On kinship structure, female autonomy, and demographic behavior in India.' Population and Development Review, 9(1), pp. 35-60.

Eapen, M. (2004). 'Women and work mobility: Some disquieting evidences from the Indian data.' Centre for Development Studies: Working Paper No. 358. Trivandrum, Kerala.

Franke, R. W. and Chasin, B. H. (1994). Kerala: Radical Reform as Development in an Indian State (2nd Edition). Institute for Food and Development Policy/Food. New Delhi: First Books.

Fawcett, F. (1985). Nayars of Malabar. New Delhi: Asian Educational Services.

Fuller, C. L. (1976). The Nairs Today. Cambridge: Cambridge University Press.

Gangadharan, A. (2010). 'Paradoxes of agricultural transformation: Changing gender roles and power relations in Kerala.' [online] Unpublished $\mathrm{PhD}$ Thesis, University of Leicester. [Accessed on 21 August 2013] Available at: $<$ https://lra.le.ac.uk/bitstream/2381/7459/1/ thesisfinal.pdf $>$.

Ghadially, R. (ed.). (2007). Urban Women in Changing India: A Reader. India: SAGE Publications.

The Global Gender Gap Report. (2016). The Global Gender Gap Report. Geneva: World Economic Forum.

Gonzales, M. C., Jain-Chandra, S., Kochhar, M. K. and Newiak, M. M. (2015). Fair Play: More Equal Laws Boost Female Labor Force Participation. Washington, DC: International Monetary Fund.

Gough, K.E. (1954). The Traditional Kinship System of the Nayars of Malabar. Cambridge: Harvard University Press.

Government of India (2011). Kerala Population Census Data 2011. Census of India, Central Statistical Organisation. [Accessed on 28 August 2016] Available at: <www.census 2011.co.in/census/state/kerala.html> 
Government of Kerala (GoK) (2015). 'Economic review.' State Planning Board: Kerala. [Accessed January 2017] Available at: <http://spb.kerala.gov.in/images/er/er15/index. html>

Government of Travancore. (1908). 'Travancore Marumakkathaym committee report.' Trivandrum: Government Press.

Hall, S. (ed.). (1997). Representations. London and Thousand Oaks, CA: SAGE Publications.

Harvard Kennedy School Review (2016). The Gaps in India's Growth Story. [Accessed on 25 August 2016] Available at: <http://harvardkennedyschoolreview.com/ the-gaps-in-indias-growth-story/>.

Heller, P. (2001). 'Moving the state: The politics of democratic decentralization in Kerala, South Africa, and Porto Alegre.' Politics and Society, 29(1), pp. 131-163.

Heller, P., Harilal, K. N. and Chaudhuri, S. (2007). 'Building local democracy: Evaluating the impact of decentralization in Kerala, India.' World Development, 35(4), pp. 626-648.

Hicks, G. (1989) 'The Four Dragons: an enthusiast's reading guide', Asian-Pacific Economic Literature, 3(2), pp. 35-49.

Hossain, M., Kathuria, R. and Islam, I. (2010). South Asian Economic Development (2nd Edition). Oxon: Routledge.

Howcroft, D. and Richardson, H. (eds.). (2009). Work and Life in the Global Economy: A Gendered Analysis of Service Work. London: Palgrave Macmillan.

Huppatz, K. (2009). 'Reworking bourdieu's Capital': Feminine and female capitals in the field of paid caring work.' Sociology, 43(1), pp. 45-66.

Jeffrey, R. (1976). The Decline of Nayyar Dominance: Society and Politics in Travancore, 1847-1908. New York: Holmes and Meier.

Jeffrey, R. (1993). Politics, Women and Well-Being: How Kerala Became a "Model". Cambridge Imperial and Post-Colonial Studies Series. London: Palgrave Macmillan.

Jeffrey, R. (2004). 'Legacies of matriliny: The place of women and the "Kerala Model".' Pacific Affairs, 77(4), pp. 647-664.

John, M. E. (2007). 'Women in power: Gender, caste and the politics of local urban governance.' Economic and Political Weekly. [online] 29 September-05 October. 42(39), pp. 3986-3993.

John, J. (2009). 'A study on Kudumbashree Project: A poverty eradication programme in Kerala - performance, impact and lessons for other states.' Planning Commission, New Delhi, India. [Accessed on 20 December 2016] Available at: <www. planningcommis sion.nic.in>.

Jose, S. and Nair, L. V. (2011.) 'Women SHGs in coastal Kerala: The lope side of social development?' International Journal of Sociology and Anthropology, 3(2), pp. 56-60.

Kapadia, K. (2010). 'Liberalisation and transformations in India's informal economy: Female breadwinners in working-class households in Chennai.' In: Harris-White, B. and Heyer, J. (ed.), The Comparative Political Economy of Development: Africa and South Asia, pp. 267-290. New York: Routledge.

Khera, R. and Nayak, N. (2009). 'Women workers and perceptions of the National Rural Employment Guarantee Act.' Economic and Political Weekly, 44(43), pp. 49-57.

Kishwar, M. (1999). Off the Beaten Track: Rethinking Gender Justice for Indian Women. New Delhi: Oxford University Press.

Kodoth, P. and Eapen, M. (2005). 'Looking beyond gender parities, gender inequalities of some dimensions of well being in Kerala.' Economic and Political Weekly, 40(30), pp. 3278-3286.

Kodoth, P. (2008). 'Gender, caste and matchmaking in Kerala: A rationale for dowry.' Development and Change, 39(2), pp. 263-283. 


\section{Situating gender capital in Kerala}

Kudumbashree (2016). 'History and background.' Online. Available at: <www.kudumbashree.org/>.

Kurien, J. (1995). 'The Kerala model: Its central tendency and the outlier.' Social Scientist, 23(1-3), pp. 70-90.

Lahoti, R. and Swaminathan, H. (2016). Economic Development and Women's Labor Force Participation in India. Feminist Economics, 22(2), pp.168-195.

Lal, D., Ojha, A. and Sabharwal, N. S. (2015). 'Issues of under-representation: Mapping women in Indian politics.' Journal of South Asian Studies, 3(1), pp. 93-102.

Lepowsky, M. (1993). Fruit of the Motherland: Gender in an Egalitarian Society. New York: Columbia University Press.

Lindberg, A. (2001). Experience and Identity: A Historical Account of Class, Caste and Gender Among The Cashew Workers of Kerala, 1930-2000. Sweden: Lund University.

Mannathukkaren, N. (2010). 'The "poverty" of political society: Partha Chatterjee and the People's Plan Campaign in Kerala, India.' Third World Quarterly, 31(2), pp. 295-314.

McCall, L. (1992). 'Does gender fit? Bourdieu, feminism, and conceptions of social order.' Theory and Society, 21(6), pp. 837-867.

Menon, N. (2009) 'Sexuality, caste, governmentality: Contests over "gender" in India.' Feminist Review, 91, pp. 94-112.

Menon, S. (1978). Cultural Heritage of Kerala: An Introduction. Kerala: East-West Publications.

Mitra, A. (2014). 'Son preference in India: Implications for gender development.' Journal of Economic Issues, 48(4), pp. 1021-1037.

Mitra, A. and Singh, P. (2007). 'Human Capital attainment and gender empowerment: The Kerala paradox.' Social Science Quarterly, 88(5), pp. 1227-1242.

Mohindra, K. S., Haddad, S. and Narayana, D. (2012). 'Debt, shame, and survival: Becoming and living as widows in rural Kerala, India.' BMC International Health and Human Rights, 12(28), pp. 1-13.

Mukhopadhyay, S. (2007). The Enigma of the Kerala Woman: A Failed Promise of Literacy. New Delhi: Social Science Press.

Nair, K. N. and Menon, V. (2007). 'Distress debt and suicides among agrarian households: Findings from three village studies in Kerala.' Centre for Development Studies. Working Paper No. 397. Trivandrum, Kerala.

National Crime Records Bureau (NCRB). (2015). National Crime Records Bureau, Ministry of Home Affairs (MHA), Government of India, [online]. New Delhi. [Accessed on 25 August 2016] Available at: <http://ncrb.gov.in/>.

Olsen, W. and Mehta, S. (2006). The right to work and differentiation in Indian employment. Indian Journal of Labour Economics, 49(3), pp.389-406.

Oommen, M. A. (1993). Essays on Kerala Economy. New Delhi: Oxford University Press.

Parayil, G. (2000). Kerala - the Development Experience: Reflections on Sustainability and Replicability. London: Zed Books.

Paniker, P. G. K. and Soman, C. R. (1984). 'Health status of Kerala: The paradox of economic backwardness and health development.' Center for Development Studies. Thiruvananthapuram.

Patrick, H. (2005). 'Reinventing public power in the age of globalization: Decentralization and the transformation of movement politics in Kerala.' In: Ray, R. and Katzenstein, M. F. (eds.), Social Movement in India: Poverty, Power, and Politics, pp. 79-100. Oxford: Rowman \& Littlefield Publishers.

Puthenkalam, J. (1977). 'Marriage and the family in Kerala with special reference to matrilineal castes.' Journal of Comparative Family Studies: Monograph Series.Calgary: University of Calgary, Department of Sociology, p. 236-241. 
Radhakrishnan, P. (1989). Peasant Struggles, Land Reforms and Social Change: Malabar, 1836-1982. New Delhi: SAGE Publications.

Raj, K. N. (1970). 'Ownership and distribution of land.' Indian Economic Review, 5(1), pp. 1-42.

Raj, K. N. and Tharakan, P. K. M. (1983). 'Agrarian reform in Kerala and its impact in the rural economy: A preliminary assessment.' In: Ghose, A. K. (ed.), Agrarian Reforms in Contemporary Developing Countries. A Study Prepared for the International Labour Office Within the Framework of World Employment Programme, pp. 31-90. London: Routledge.

Ramachandran, V. K. (1997). 'On Kerala's development achievements.' In: Dreze, J. and Sen, A. (eds.), Indian Development: Selected Regional Perspectives, pp. 205-325. Oxford: Clarendon Press.

Ravi Raman, K. (2002). 'Breaking new ground: Adivasi land struggle in Kerala. Economic and Political Weekly. [online] 9-15 March, 37(10). [Accessed on 19 August 2013] Available at: $<$ www.jstor.org/discover $/ 10.2307 / 4411834$ ?uid $=2 \& u i d=4 \&$ sid $=21102564293743>$.

Ravi Raman, K. (ed.). (2010). Development, Democracy and the State: Critiquing the Kerala Model of Development. London: Routledge.

Rohini, P. H. (1991). 'Women workers in manufacturing industry in India: Problems and possibilities.' In: Afshar, H. (ed.), Women, Development and Survival in the Third World, pp. 260-287. Essex: Longman Group.

Sabanna, A. (2016). 'Women empowerment in India: Some issues.' Global Journal for Research Analysis, 5(7), pp. 218-219.

Saradamoni, K. (1994). 'Women, Kerala and some development issues.' Economic and Political Weekly. [online] 26 February, 26(9), pp. 501-509.

Saradamoni, K. (1999). Matriliny Transformed: Family, Law and Ideology in Twentieth Century Travancore. New Delhi: SAGE Publications.

Sassen, S. (2007). A Sociology of Globalization: Contemporary Societies Series. New Yok: Norton.

Sen, A. (1992). 'Missing women.' BMJ: British Medical Journal, 304(6827), p. 587.

Sen, A. and Dreze, J. (1996). India: Economic Development and Social Opportunity. New York: Oxford University Press.

Sen, G. (1992). 'Social needs and public accountability - the case of Kerala.' In: Wuyts, M., Mackintosh, M. and Hewitt, T. (eds.), Development Policy and Public Action, pp. 253-278. London: Open University Press.

Sharma, U. (1980). Women, Work and Property in North West India. London: Tavistock Publications.

Shihabudheen, N. (2013). 'What is right and wrong with Kudumbashree: The field experiences.' International Journal of Humanities and Social Science Invention, 2(5), pp. 9-21.

Shreekumar, S. (2007). "The land of "gender paradox"? Getting past the commonsense of contemporary Kerala'. Inter-Asia Cultural Studies, 8(1), pp. 34-54.

Shoemaker, N. (1991). 'The Rise and Fall of Iroquois Women'. Journal of Women's History 293, pp 39-57.

Singh, P. (2015). Solidarity Works for Welfare Subnationalism and Social Development in India. New York: Cambridge University Press.

Skeggs, B. (1999). 'Challenging masculinity and using sexuality.' British Journal of Sociology of Education, 12(2), pp. 127-139.

State Crime Records Bureau (2016). Crimes against women 2016. [Accessed May 2017] Available at: $<$ http://old.keralapolice.gov.in/newsite/crime_against_women_2016.html $>$. Thiruvanthapuram: Kerala. 


\section{Situating gender capital in Kerala}

Steur, L. (2011). 'Adivasis, communists, and the rise of indigenism in Kerala.' Dialectical Anthropology, 35(1), pp. 59-76.

Tharakan, P. M. (1998). 'Socio-religious reform movements, the process of democratization and human development: The case of Kerala, South-West India.' In: Rudebeck, L., Törnquist, O. and Rojas, V. (eds.), Democratization in the Third World, pp. 144-172. London: Palgrave Macmillan.

Tharamangalam, J. (ed.). (2006). Kerala: The Paradoxes of Public Action and Development. New Delhi: Orient Longman.

Thomas, J. J. (2012). 'India's labour market during the 2000s: Surveying the changes.' Economic and Political Weekly, 47(51), 22 December 2012, pp. 39-51.

The Times of India. (2012). 'Declining child sex ratio in state alarms Unicef.' [Accessed on 20 July 2012] Available at: <http://timesofindia.indiatimes.com/city/thiruvananthapuram/Declining-child-sex-ratio-in-state-alarms-Unicef/articleshow/15050283.cms>.

Tornquist, O. T. (2000). 'The new popular politics of development: Kerala's experience.' In: Parayil, G. (ed.), The Development Experience: Reflections on Sustainability and Replicability, pp. 116-138. London: Zed Books.

Tornquist, O. and Tharakan, P. M. (1996). 'Democratisation and attempts to renew the radical political development project: Case of Kerala.' Economic and Political Weekly, pp. 1953-1973.

Upadhyay, U. D. (2000). 'India's New Economic Policy of 1991 and its implication on women's poverty and AIDS.' Feminist Economics, 6(3), pp. 105-122.

Varghese, T. C. (1970). Agrarian Change and Economic Consequences: Land Tenures in Kerala, 1850-1960. New Delhi: Allied Publishers.

Veron, R. (2001). 'The “new” Kerala model: Lessons for sustainable development.' World Development, 29(4), pp. 601-617.

World Bank (2015). South Asia: Overview Context. [Online] [Accessed on 13 September 2016] Available at: <www.worldbank.org/en/region/sar/overview\#1>.

Yuval-Davis, N. and Anthias, F. (1989). Women-Nation-State. Basingstoke: Palgrave Macmillan.

Zachariah, K. C. and Irudayarajan, S. (2007). 'Economic and social dynamics of migration in Kerala, 1999-2004.' Analysis of Panel Data. Thiruvananthapuram: Centre for Development Studies.

Zachariah K. C. and Irudayarajan, S. (2012). Kerala's Gulf Connection, 1998-2011: Economic and Social Impact of Migration. Hyderabad: Orient Blackswan. 


\section{$4 \quad$ Matriliny and kinship \\ Transforming gendered habitus in semi-rural livelihoods}

This chapter analyses how intra- and inter-household differences are constitutive of gender and other social relations but are continually shaped by larger contours of socio-economic change, all of which has implications for women's autonomy. It locates gender relations and women's experiences of gender relations within households through their interaction with kinship and caste practices and doing so within a framework of intersectionality. This facilitates further understanding of Bourdieu's symbolic order of gender in the context of households - a place where a gendered habitus emerges as an embodied form through the social construction of gendered practices, norms and dispositions. In doing so, this chapter explores the interactions between different forms of capital within households, with outcomes related to female autonomy, which is critical for development and social goals. Initially, the chapter draws observations on gendered habitus, bargaining power and autonomy, focusing on aspects of changing forms of matriliny and kinship within the rural Keralan context to delineate aspects of women's autonomy within the household; it then proceeds by discussing findings on gendered relations in rural livelihoods.

\section{Gendered habitus: capitals, bargaining power and autonomy}

In his Masculine Domination (2001), Bourdieu draws on the traditional peasant Kabyle society in Algeria, where social order is based on a fundamental male/ female dichotomy, and argues that social practice involves classifying and that gender classification is a powerful form of such processes (Krais, 2006). Such a social practice constitutes and reproduces domination in people's immediate interactions with structures such as households, which can be sites of social practice, or what Bourdieu calls "fields". Here, habitus works as the practical operator, and in its simplest terms, habitus concerns the perceptions, social norms, values and dispositions that generate social constructions of gender within dichotomies of masculinity and femininity. The gender-specific habitus manifests itself in an internalized identity that embodies the division of labour between the genders; this happens through bodily and gendered practices, where such masculine or feminine traits are social constructs (Krais, 2006). Similarly, gender and development debates that have situated women's experiences of gender relations within 
households have focused on their interaction with gender, kinship and caste practices (see Palmer, 1991; Kabeer, 1994; Kandiyoti, 1998) that generate social norms based on masculine and feminine constructs of power relations. Women's status within kinship and marriage practices is complex, varied and flexible, but it nevertheless determines women's role and position within the family (Chari, 2004; Harris-White and Heyer, 2010). In Bangladesh, Kabeer (1994) shows how as an example of classic patriarchy, women, through social norms, are excluded from extra-household productive activities. This, in many ways, relates to Bourdieu's classification of gender and his definition of masculine domination, which he deems as nothing other than 'a somatization of the social relations of domination' (Bourdieu, 2001, p. 23), but this is very much evidenced on the extent of male bias within gender and development discourses (see Elson, 1995). Therefore, understandings of gender relations solely in terms of class divisions based on economic and material resources are problematic within development contexts, as access to resources are often linked through their men (Delphy, 1977).

The household as a site of conflict and inequality is well noted (Dwyer and Bruce, 1988; Mencher, 1987), but it also involves power dimensions and cultural expectations. Moreover, different intra-household relations approaches address various matters: the politics of domestic budgeting (Whitehead, 1984); transaction (Pollack, 1985); altruism ${ }^{1}$ (Folbre, 1986); co-operative conflict $^{2}$ (Sen, 1987); the politics of consumption (Elson, 1994); and bargaining power (Agarwal, 1997). Agarwal (1997) shows how the last of these, bargaining power, is constitutive of social norms ${ }^{3}$ and seen as endogenous in intra-household dynamics, which is extremely useful in exploring how power asymmetries play out through the interaction between structures of caste and kinship. Women's bargaining power as a measure to understand intra-household dynamics and gendered systems of social practices relates to asset ownership and property rights, but ultimately concerns their welfare and experience of violence, as the former pair can influence the latter pair. Indeed, Agarwal (1997) focuses on property rights as an important constituent of women's status within social and economic analyses, particularly for reducing domestic violence (Agarwal and Panda, 2007). Thus, all forms of capitals possessed (or inherited) by women - for example, economic capital such as income and employment, asset ownership through inheritance or dowry, as well as human capital such as education - play a key role in determining women's autonomy and achieving key developmental goals. For instance, access to capital may be determined by cultural practices and norms such as bride price and dowry, caste practices ${ }^{4}$ or women's ability to bear sons etc. Through the social practices of endogamous marriages, control over both the labour and the sexuality (and bodies) of women is maintained, making them akin to "docile" bodies. Meanwhile, notions of purity and pollution reify social groupings and "distance", thus regulating women's mobility (and sexuality) - with caste practices regarding endogamous marriages or the concept of "izzat" (honour) in Muslim communities being specific examples.

Kabeer (1994) notes that women's access to capital (resources) is embedded in familial and domestic responsibilities, but relative autonomy over material 
resources may not necessarily translate into improved levels of well-being. Through the lens of habitus it seems as though adhering to social norms that define gender roles makes individuals predisposed to act in particular ways through the habitus they have acquired from experience, which acts as an 'internalized set of tacit rules governing strategies and practices in the field' (Moi, 1990, p. 271). These internalized structures lead to hierarchical processes of domination and subordination, and they carry the notion of history, or embodied history (Bourdieu, 1990), which generates different outcomes (Lawler, 2004) for different groups. For example, Liddle and Joshi (1986) say the subordination of women is critical to caste hierarchy, with upper-caste women accorded more constraints over mobility and sexuality - for example, with increased economic mobility - and even being withdrawn from outside work through practices of sanskritisation. ${ }^{5}$ Although women from lower castes (and tribes) have relatively less constraints, they face increased material deprivation and less access to capability-building activities such as education (Arun et al., 2013). The social outcomes of gendered habitus differ not only between men and women but also between women themselves, such as for different caste groups. Gender classifications should therefore incorporate material and cultural resource structures as well as changing agrarian conditions so that inequalities between men and women - and indeed between groups of women - can be understood.

Habitus is acquired unconsciously through lived experience in a certain position within the social world and is created through a social process that shifts in relation to specific contexts and over time (Navarro, 2006). For example, in Kerala rigid caste customs in relation to untouchability or social pollution are not practised. However, caste practices traverse kinship and class, and they play important roles in defining gender relations in the household through control, ownership and access to resources, marriage relations, work participation and engagement with the markets and the wider community. These are explored next.

\section{Kinship structures and gender relations in Kerala}

As seen in Chapter 3, for a long time Keralan society was dominated by casteism and feudalism whereby the upper Hindu castes of Namboothiris and Nairs held a privileged position, particularly in terms of land ownership and social prestige (Jeffrey, 1976). The changes agrarian and socio-religious movements brought have indeed altered caste and social relations, yet practices of social exclusion and disadvantage persist (Uyl, 2000). Similarly, Osella and Osella (2000) highlight the complexities and contradictions of identity and material struggles faced by the relatively disadvantaged caste group of Ezhavas in Kerala. As seen in Chapter 3, for decades there has been much interest about the caste practices of Kerala's Nair communities (Fuller, 1975; Jeffrey, 1976; Menon, 1978; Saradamoni, 1994; 1999), particularly due to their system and practices through inheritance, marriage and the household structure of matrilineal families. We see that debates on such kinship practices premised on Eurocentric notions of family and patrilineal systems culminated in legislation to reform matrilineal practices (see Fuller, 
1975). Thus, various social, economic and political changes over the nineteenth and early twentieth century have transformed Nair women's identity, security and autonomy (Jeffrey, 1976), and with the gradual adoption of patriarchy practices, ${ }^{6}$ have brought about changes to gender and social relations.

This chapter will try to capture some of the effects of these changes on gender roles within a semi-rural context in southern Kerala, doing so through a comparative analysis of the structures of household - as defined primarily by kinship that influence women's work and gender roles. In general, the diversification of farm livelihoods and its implications for rural households is well documented (Ellis, 2000; Yunez-Naude and Taylor, 2001; Razavi, 2002). While some propose the d-agrarianisation thesis (Bryceson, 2002) that must consider the complexity and diversity of rural livelihoods (Ellis, 2000), as rural livelihoods are differentiated by social identity: class, gender and age (Kepe, 2008). Of course, livelihood options are mediated by both exogenous and endogenous factors. Exogenous factors (e.g. policy changes, resource endowments and access to markets) influence the nature of both diversification and livelihood strategies (Ellis, 2000; Kabeer and Thi Van Anh, 2002). Similarly, endogenous factors in the form of internal dynamics reveal the household to be a site of bargaining, negotiation and conflict (Whitehead, 1984; Dwyer and Bruce, 1988; Sen, 1987; Agarwal, 1997). Both of these types of factors will be taken up in the Kerala context.

\section{Data and findings}

For this study, key issues of gender relations unravelled through studying kinship practices of farm households in Kerala in terms of work, access to capital and power relations. In order to extract the embedded and elusive nature of power within households, the fieldwork focused on gender-sensitive and informed qualitative research methods because, as Kabeer (1994, p. 134) says, 'It is frequently the "silences" and "absences" within the research encounter, the information that is withheld rather than which is volunteered, which signal the presence of disempowering relations'.

Thus, gender orders that determine hierarchies, differences and inequalities in power are further built into gender relations, emerging from the gendered habitus as these are socially constructed and concealed, and often difficult to understand through quantification. The uncovering of social experiences and the subtle and concealed nature of power relations are relevant to theoretical formulations and policy interventions. This also necessitates linking the household to the community, the market and the state rather than treating it in isolation (Agarwal, 1997).

For this study, semi-structured interviews based on ethnographic research were conducted with 45 households belonging to Ummanoor Panchayat in Kerala's district of Kollam. The study allowed comparison of households based on a demographic and agricultural mix. For example, because of its topography (i.e mix of both high and low lands) the region has a combination of crops such as rice (paddy), tapioca, coconut, rubber, pepper, banana, mango and cashews. The average per-family holding of farmland is 0.21 hectares, ${ }^{7}$ or 0.51 acres (GOK, 2015). 
Around 70 per cent of the district's labour force is engaged in agriculture or allied activities, including historically noted cashew nut cultivation and processing. In terms of demographic population, there is a good level of heterogeneity of major social groups, such as Hindus (Nairs, Ezhavas and Pulayas) and Christians, belonging to different types of households, such as nuclear, extended and joint family households. All this allowed analyses of differing social practices such as inheritance, gender roles and relations. The sample consisted of 39 per cent for nuclear households, 37 per cent for extended households and 23 per cent for joint families, with the women aged between 32 and 72. The various ethnographic tools used were conversations, semi-structured interviews, oral histories and observations with these women in the June-July 2010 period, returning for four weeks in August 2014. I also called on research I conducted during my PhD in 1996, allowing me to revisit some of these households. In general, women described themselves as housewives (veetamma), though they have a significant presence and participate in farm activities, particularly in households where the men were migrants. Around 30 per cent of these women were in paid employment (teachers, employees in the public sector etc).

The structure of the household and the relevance of caste and religion are undergoing many changes but still have much relevance for positioning gender relations, which forms the central discussion of this chapter. The size of landholdings in the panchayat shows that nearly 76.13 per cent of holdings is below 0.50 acres, while 19 per cent is 0.5 to 2 acres of land (GOK, 2006). The sample population was classified by the size of landholding: marginal landholdings were grouped with those with less than 0.50 acres, small holders were in the group for 0.50-1 acre, medium ownership 1-2 acres and large ownership with 2+ acres. Only 4.4 per cent of the holdings belong to those in the $2+$ acres group. In the sample, over 62 per cent of households owned a marginal size of land that is less than half an acre. This is because of the increased fragmentation of land, which has created problems in farming. Many social changes, including the decline of the joint family system and the emergence of neutral families, have resulted in a demand for more land for housing, so agriculture is steadily losing its importance. Questions on the role of farming practices and gender relations as well as the forms of capital gained and used by women are explored against changing social and economic changes, such as landholdings and the role of kinship and caste practices, are discussed below.

\section{Ummanoor Panchayat: a socio-economic profile}

As seen from Chapter 3, the changes in Travancore (southern Kerala) which brought about relatively higher development of social and economic infrastructure in the nineteenth century have transformed farming practices, cropping patterns and land use in the state. Thus, even 100 years ago in Ummanoor, which falls within the Travancore region, other castes were granted the privilege of education by the missionary church with the advent of the Valakom primary school. Of the six panchayats of Vettikavala block, Ummanoor is the most differentiated 
in terms of its varied geological conditions. This panchayat has four types: high lands (13.4 per cent), very steep lands (2.5 per cent), hilly lands (62.3 per cent) and valleys (21.8), thus allowing for a mix of crops (GOK, 2006). Agriculture is the predominant economic sector in this panchayat. The major source of secondary activities is cashew processing with other minor activities being, for example, brick building, oil processing and milk distribution. The previously dominant cashew processing factories (kudivaruppu) have now declined with only a handful now employing mostly women (GOK, 2006). The large-scale displacement of labour, mostly of women, has led women to take seasonal work in the farmlands and brick industry. Engagement in the service sector, such as in schools or government departments, is also common as there was a wide range of primary and secondary institutions, including Christian-aided and government schools. The matrilineal system of familial relationships and inheritance is largely followed by Nairs in this region. Women's work within and beyond the household varies according to land ownership, familial and domestic responsibilities, social norms, and sources of income and caste. This is also true for access to resources. For example, while in matrilineal Nair households women inherit property such as land or a house (the main place of dwelling), this is not the case for Christians and other lower castes. There are complex relationships at play here, so this chapter will address critical aspects of intra-household habitus from a gender perspective.

\section{Changing cropping system and transforming gender order}

As previously discussed, from changes in the joint family and the distribution of land along with social changes such as higher levels of literacy, agricultural households have undergone colossal changes in Kerala. In the study area (e.g. in Ummanoor), janmikudiyan (landlordism) was prevalent before the land reform period when land was owned by tharavad (joint families) and other upper classes. Respondents recalled how landlord-tenant relations changed with the land reforms and development planning policies because of the five-year plans, agricultural development programmes and social developments. The farmland can be divided into parambu (dry homestead land) and nilam, or kandam, (wetlands). With the increasing number of joint-family partitions, male migration, income diversification through small businesses and preferences for paid employment in the service sector, inheritance and dowry practices have changed. Also, wider stagnation in the state's agriculture sector has led to a decline in farming as an occupation. Nevertheless, this has also allowed households from such lower classes as Ezhavas and Pulayas to buy and own smaller sizes of land. Thus, holdings continue to be small holdings. For example, small farms, which were 1-2 acres, formed 20 per cent of the sample, while medium farms were 13 per cent and large 5 per cent. Marginal farmers, forming 62 per cent, were mostly from lower socio-economic groups who are involved in agricultural labour or other farm labour. Former large farms have reduced the extent of their farming because of the high cost of cultivation, increasing paid employment in the service sector and lower profitability. 
As Nair and Menon (2007) note, this has caused much agrarian distress through lower earnings and increasing indebtedness.

An increase in other occupations, such as teaching and central and state government jobs, has also reduced the extent of agricultural activities. In addition, an increase in artisanal occupations like carpentry, mechanics and plumbing has reduced the supply of farm labour, bringing higher wages to the farm sector. Income diversification via occupational diversification is therefore prominent to some extent in most farming households. More and more farm households are selling their wetlands for house construction or other purposes while maintaining their homestead gardens.

Similarly, changes in the cropping pattern show that labour-intensive crops like rice and tapioca have been replaced by less labour-intensive crops such as rubber and coconut. In a ten-year period in Ummanoor, the acreage under rubber has increased while that devoted to coconut, rice and tapioca has fallen. Rubber is cultivated in nearly 55 per cent of the Panchayats, even in small and marginal holdings, so has encroached on both upland and rice lands. Other trees include jackfruit, mangoes and cashew nut, while other minor crops include tapioca, banana, ginger and yam. Natural rubber has witnessed high growth in Kerala during the past four decades in terms of area cultivated, production and productivity, yet price fluctuations have caused instability of income. Although rubber is popular in this region because of the topographical conditions, it is not without problems. As rubber is a perennial crop with a long gestation period, this has implications for replanting small holdings, so marginal farmers with less than 0.10 acres of land cannot afford to plant rubber. Also, other smallholders faced income instability through replanting rubber. The increase in rubber cultivation has led to lower food production and most households have to purchase rice for consumption and straw for cattle. Similarly, cashew and other tree crops are grown to a lesser extent in homestead gardens as rubber is substituted for tree crops, which has reduced the grazing area and supply of fodder for livestock. This has also affected cultural relationships with farm and farming practices. As one participant, Radhamma (52, housewife), says:

The decline in rice or paddy cultivation has signified change to cultural ways in which the farm and farm produced is valued, for example, our cultural festivals such as Vishu and Onam no longer hold any meaning for harvest practices. These crops were part of the family culture, in term of their use for various purposes, and sharing of the crop among households. Rubber as a farm produce is not part of the household, and as a perennial crop, it does not hold any meaning for our seasonal festivities. Again, we do not have the same relationship with the rubber tapping workers, as we did with paddy workers.

Previous research has shown how cropping patterns in farm households also influence the nature of women's work (Dixon-Mueller, 1985; Cloud, 1994; Floro, 1995; Jain, 1997). Decline in rice cultivation in the region similarly affected the raising of livestock and poultry, as rubber is extended to both the wetland and the 


\section{Matriliny and kinship}

homesteads. However, the increased cultivation of cash crops does not necessarily translate to an increased allocation of resources in the household, as Sarassama (56, housewife) explains: 'When rice was cultivated, women at least were ensured of good quality food for the family and ample fodder for animals. With rubber, our work increases but not personal income or food.' Another major constraint in the farm sector is the shortage of labour and resultant high wages. There has been a steady rise in the average daily wage of workers in the state; the same applies to the studied regions.

Rubber and other tree crops are less labour intensive than rice. Also, rubber cultivation generates a demand for labour during the first three to five years only. After that, skilled labour is required for tapping, which is done by men. Furthermore, labour rates for women are much lower than those for men. Their wages are about only half of men's wages in the cultivation of crops like rice, which is mostly female intensive. Male labour is mainly utilized in fertilizer application and insecticide spraying. However, in rubber cultivation, men undertake the skilled job of rubber tapping, which involves more family. At the same time, traditional conceptions of women's work in agriculture, particularly in relation to food crops, are applied in the farms. For example, women do not engage in higherwage-paying activities related to cash crops such as rubber tapping and coconut harvesting. Given the decline in food crop cultivation and the rise in smallholder cropping, the Kudumbashree Mission has strengthened the practice of group or collective farming to increase agricultural production as well as involve women through Neighbourhood Households Groups (NHGs). This programme is implemented in most districts, including in the study areas, with the support of local self-help groups (see Kudumbashree, 2016). Thus, changes in land ownership, social trends in income diversification and cropping patterns have indeed transformed relationships with landed property and farming practices.

\section{Matrilineal practices and changing forms of domination}

Women's access to capitals in farm households relates to operation of habitus, the social structure of the households, and cultural norms and practices. The invisibility of women's contribution to agriculture derives from traditional interpretations of concepts like work, economic activities, the workplace and economically active population, particularly within food crops. The gendered division of labour in farm work also reflects the social norms reflected in attitudes about gender tasks because, as Agarwal (1997) notes, social norms play an important role in determining the position of gender in households and are not only an important determinant of but also constraint to bargaining power. Gender ideologies that prescribe gender roles also influence customary laws and even determine women's individual property rights (ibid.), as seen through the matrilineal system of inheritance.

Nairs' system of matrilineal descent is important for property inheritance and the positioning of gender categories. This includes matrilocal practices where the daughter's husband lives with his wife's family, which allows continuity of 
property ownership. Among other groups such as Christian households, the joint household is mostly a patrilineal one and is therefore mostly patriarchal in nature. In recent times, after marriage sons have tended to move out of the tharavad with their wives but to within a short distance (sometimes in the same family compound). However, in most cases there is mutual access to the ancestral households just as before, so the tharavad's central role concerns maintaining continuity among various households in terms of allocation of property and positioning of gender categories. In my sample, Nairs had mostly joint households with three generations, and three households in the sample were polyandrous in nature. Relations within polyandrous families varied, as described through narratives of oral history. For example, Lakshmiamma, 71, says: 'I live with two husbands who are brothers. I married the eldest brother when I was 17 years old. Thus, the family property is retained within the family. We have three children, who are all grown up.' This practice was once very common among Nairs but is no longer popular, although households with older generations like Lakshmiamma still exist to narrate such social practices.

Many extended households in Ummanoor own relatively large amounts of land (more than five acres). In these households, married sons or daughters live with their parents, sisters and brothers, and other dependants. Joint households have combined household duties and responsibilities such as help with childcare; the sharing of jobs, income, food, and work and agricultural produce; the lending of money; joint farm operations and purchase of capital; and the borrowing of farm implements. Usually the most senior male member controls farm activities (e.g. the eldest son or son-in-law). The eldest maternal uncle (karanavar) is instrumental in decision-making processes in Nair households in terms of marriage and property division. For example, in one household of five brothers, the mootha chetathy (eldest sister-in-law) is well respected by younger sisters, sisters-in-law and brothers. The other sisters-in-law were very conscious of her presence when she was talking with me. Her role in decision-making in key matters such as property, marriages and other economic decisions is vital, so the positioning of gender relations and kinship structures is critical within the intra-household sphere. Cases of sibling rivalry, contested claims to property and incidents of abuse were reported in some cases. The family still remains the prominent form of social security for the aged, the disabled, the vulnerable and children in most households, and it is a social institution that sustains continuity through marriage and inheritance. Households must therefore remain central in this study, as it is difficult to assume homogeneity of households across regions and socio-economic groups.

The gender division of labour is also dictated by social norms that are designated "masculine" and "feminine". The "gender division of labour", then, is more than just a descriptive category as it indicates the differential value placed on men's work versus women's work (Mohanty, 1991). There is a good degree of social value attached to women's role in social relations (Moser, 1993), particularly with more women withdrawing into domesticity because of changes in farming practices, male migration and social norms. Women are primarily responsible for religious and social duties, but also for maintaining vital links 
within the family and community. For example, women represent the household by attending at important social events like weddings, child-naming ceremonies (noolukettu), engagements, house-warmings and funerals, so they maintain social solidarity within the community and family, and they also participate in symbolic religious practices such as lighting lamps at dusk and visiting temples and churches. Such forms of socialisation have emerged from notions and practices of gendered habitus within and beyond the household. This also reifies how cultural beliefs, rites and practices are symbolic of gender relations in society, where the feminine capital is valued through cultural processes and rites, drawing on research where scholars have noted the preponderance of female-oriented rites and rituaIs in Kerala, particularly among Nairs (Gough, 1954).

The gender-caste nexus is manifested through division of labour, as women of higher castes do not perform certain "outside" tasks like shopping, paid work, etc. Most upper caste households hired help or informal help from workers or their family members who work in the farm fields. Among the lower castes, though, there is a certain degree of fluidity in work categories, as men do participate in some household tasks while women take up paid farm-related work. The amount of household work is larger in joint and extended households simply because of household composition. There are indeed different social values attached to the type of work between men and women as well as between women in different social and economic conditions.

\section{Ownership and control of capital: land, property and assets}

In Ummanoor, social norms, caste and the structure of households exert much influence on household dynamics. As seen earlier, the matrilineal system means women and daughters rather than men inherit property. But despite women having property ownership and high literacy rates, men have more control of property in terms of decision-making and rights to disposition (Arun, 2012). Nevertheless, land rights can over time help women negotiate less restrictive norms and better treatment from husbands in South Asia (Agarwal, 1997). Agarwal's 1995 book, In One's Own Field, shows how independent property rights are important for gender relations - more in terms of control rather than mere ownership of material resources. However, access to resources should always differentiate between control and ownership of resources because these can be understood differently. In the sample, women from Nair households often own resources such as the house and farmland, and they have a certain degree of bargaining power within the household, which is confined to discussions on prime economic affairs as well as those affecting education and marriage matters regarding their children. There is, though, a tendency for "restricted" ownership as women are not so involved in farm activities or productive employment compared with men, which also restricts the woman's activities and decision-making, and the prime domain for women is confined to social and biological reproduction, through household work, child care and other cultural practices. 
Arranged marriages have always been as the "norm" as this defined social status, honour and generational reproduction. Marriage was 'arranged' between families from similar social locations, primarily among religious and caste groups. In all, social norms, an important aspect of habitus and, consequently, bargaining power and autonomy, reflect gender order through attitudes, perceptions, behaviours and practices. These also reflect both symbolic and social hierarchical practices.

A respondent, Parvathy (32, housewife), reflected:

The single most dominant form of male hierarchy can be reflected in our daily social practice of food. Women and wives often serve food for men first, it is often usual for wives to eat from the husband's plate, this displays a very symbolic gesture of servitude. I do not think it would be the other way around!

Thus, such norms and behaviour create not only power discourses but also create and define sets of ideas as well as ways of thinking that may be interpreted as widely accepted practice for gendered relations. Through such discourses, power is a multilayered phenomenon similar to a Foucauldian lens, where power is exercised on different levels of human and social relations, although we move away from a centralized notion of power. This interplay of power, through social control, works to "control" bodies, sexuality and even minds, creating and re-creating gendered and docile bodies through definitions of work, care and responsibilities. Docile bodies here refer to how notions of beauty, white complexion and healthy bodily practices such as use of ayurvedic oils, massages and treatments to maintain bodily capital is also transmitted to girls through mothers and grandmothers. Such practices are more pronounced during pregnancy and post-natal care to maintain the health and "figure" and beauty of the mother and the unborn child through practices such as hot baths, use of turmeric and herbs, kumkum (saffron), etc. Thus, prime importance is placed on the feminine capital, as it is critical for physical, reproductive and sexual health, and is thus passed on as forms of international transmission of norms and practices. As such, economic capability through education and ownership of assets such as land, a house or employment status may not necessarily translate into equality in everyday social and gendered relations, as, to a large extent, social norms dictate the behaviour, attitudes and codes of conduct for women within the household (Agarwal, 1997).

Social norms also restrict and determine the control of labour and labour time, determining women's intra-household bargaining position. This restriction is in respect to type of work, interaction with other members of the public and physical mobility. Parvathy (36, housewife), added:

As a graduate in engineering, I gained a job soon after my degree. This was the most exciting time of my life, as I was successful in a campus interview. I got married soon, and moved to my husband's house, and the distance to work was much longer. However I had to give up my job, with assignments that I had to do late in the evening. When my son was born, this became more difficult. 
Women continue paid employment only after careful consultation with family members, especially when it has much impact on childcare, physical mobility and long working hours. Further, women's economic autonomy decreases with lack of economic participation, even when they still inherit the family home or landed property as they do not directly access income from such assets (e.g. rubber cultivation). In landless labour households, women withdraw from manual work such as paid farm labour when their family attains higher economic status through increased wages for men or by migrating for work. Thus, women face decreased economic autonomy and social flexibility compared with men in matters of occupation, education and physical mobility. Younger women and girls are restricted from travelling alone to public places, particularly after dark, so, in a society characterized by vertical hierarchies of caste, gendered autonomy assumes varied forms within and across these social boundaries.

Preferences for paid employment are evident for occupations related to the service sector, like teaching in schools. In Nair households where women inherit property, such as the natal house, girls continue to live with their husbands after marriage (a form of matrilocal practice), enabling continuity of women's employment and more economic capability. In such cases, women can have more choices and contribute to the education of their own children, decide on occupational matters, particularly for their girls, and contribute to household finances regarding matters of savings and investment. Radhamma (46), a senior schoolteacher in a secondary school, recalls her experience:

My parents were both schoolteachers, which made it easier for me to get into this job soon after graduation. I continued to stay on in my natal family as it was closer to the school, and my husband spends time here during the week and travels to his house during the weekends. I will inherit this ancestral home and some of the farmland, which will be an important asset for our children. Sadly, my husband passed away due to cancer, so it made it all the more important that I stay here with my parents, along with my brother, who lives close by, and continue my paid employment so that I can support my children through good education.

As Agarwal (1997) purports, a fallback position is an important aspect of bargaining power, such as landed property. This study shows that paid employment allows women to enjoy both more autonomy in economic matters and closer relationships with their natal family, and these act as a buffer during crises. In the absence of women's independent economic participation, such as employment, they might have a share in some productive assets like land, bank deposits or jewellery, but these are often directly passed on to daughters, either as dowry or part of marriage expenses, or they could be used for in-household emergencies (e.g. meeting education and health costs). Women do not therefore have direct autonomy on inherited economic assets, as these are seen as "collective assets" for inter-generational transfer and as a form of social protection. Women, however, play an important role in making decisions about children's education, career and 
marriage choices. Through inheritance practices which favour parents of girls, mothers in particular play a significant supportive role in their daughters' lives, even after they are married. This role is more in matrilocal families as daughters continue to stay in natal homes, though doing this draws on their emotional capital to prevent domestic tensions. It also draws on a habitus that values the female and feminine capital that is transmitted through generations via education, cultural norms, inheritance rights, raising children and physical support for older generations. Daughters are therefore usually able to look after their parents during illness and old age. However, emerging practices show that economic assets such as farmland inherited by wives are mostly sold to invest in other economic opportunities such as business ventures, construction of houses etc. These transactions may not necessarily be done in the legal name of the women, and land ownership is treated as a form of "dowry" rather than an asset that empowers women, signalling transformation from matrilineal to patriarchal practices. This changes dyadic relationships such as those between mothers and daughters, which reduces not only the mothers' role in their lives but also their cultural capital because of such emotional intensity and cultural transmission of norms and values within families. Similarly, in a study in north-west India, Sharma (1980) showed that in addition to inheritance practices, the patterns of effective control of assets is important as many women who do inherit land have only minimal control over the land they officially own.

\section{Building new forms of capital: social capital and collective engagement}

Local self-help groups (SHGs) run through Kudumbashree can improve women's participation in the public sphere, as they allow women to activate forms of social capital and physical network with women of similar backgrounds and needs. Numerous women in the sample participated in local self-help groups, e.g ayalkootams, engaged in savings schemes and income-generating activities such as tailoring units or large micro-enterprises. Women's literacy and various forms of social capital allow them to create and benefit from economic spaces by combining their resources through collective agency. This also means women took time from household responsibilities to attend meetings, network with social and political (panchayat) members, and demonstrate both interest and awareness in social and political issues. This engagement was not so evident during my fieldwork for my $\mathrm{PhD}$ (1996-2000). Although women were then not involved with any mainstream informal political activities, their emergence into the local "political" sphere through such programmes as Kudumbashree, Janashree ${ }^{8}$ etc. helped their public visibility, identity and representation. Research has shown how women's presence and participation in local and collective institutions is key to achieving goals of welfare, efficiency and good governance (see Agarwal, 2010). Through small-scale enterprises, women's use of female capital in the wider social and political sphere was evident through their enterprising nature and involved generating additional income in forms such as tutoring primary school 
students - primarily in subjects such as mathematics, science and English - or tailoring, stitching and other minor sewing work, etc. A few, with the help of women's groups, even took business orders for local school uniforms. Income gained from such sources increased their economic capital, and its control.

The presence of women from landless households (though some owned natal family residences) in ventures of Kudumbashree group farming of food crops enables a range of benefits, primarily access to and control of land and continuity of farm cultivation. Through leasing small holdings of land, women cultivate food crops such as bananas and vegetables through small-scale cultivation, with support from the local panchayat and krishi bhavan (farm office). To some extent, household or structural attributes also play out through class relations in selfhelp groups, as women from lower castes complain of group conflicts and rivalry. However, women's presence (and absence) in collective institutions is critical for Sustainable Development Goals (SDGs) such as food production, climate change and gender equality. In her noted work on women's role in green governance, Agarwal (2010) notes how gender intersects with other social divisions such as caste in potentially conflicting ways regarding outcomes and benefits from collective participation. Nevertheless, some women reported examples of overworking (not all labour and time is paid for), poor returns (due to fluctuating farm prices), the unaccounted nature of women's work in the household and rise in traits supporting economic patriarchy. Some were concerned about higher levels of debt borrowed through the SHGs. However, others preferred this to seasonal employment as landless workers because of autonomy, control of farming and access to social networks within the region. Pankajakshi (46), an ayalkootam member, states:

I was fed up with my alcoholic husband, who spent all his earnings as a rubber tapper on drinks, then abused me and my children. He will not allow me to work as a farm labourer. By engaging with the ayalkootam through group farming, I now have some economic control through my own earnings, which I can spend on household expenses. Through small savings I can join "chitty" (informal savings) so I can support my children's education and marriage expenses.

The overall implications of gender capital and female autonomy are summarised in Table 4.1, which shows that gender has important but varying interactive effects with capital. The overall embodied nature of human capital, through education and literacy, translates into intergenerational transmission (IGT) of capital through values and norms regarding gender equality in the household. Women's paid employment improves their presence in the public sphere, offering them more agency and confidence through networks and support. This agency also helps them make decisions about their children's education and jobs, even in the absence of their males. The interaction of paid employment and other immovable assets leads to increased fallback because of matrilocal practices where women's decision-making is more evident and physical domestic abuse is reduced. 
Table 4.1 Interactive Effects of Gender, Habitus and Capital on Autonomy

\begin{tabular}{|c|c|c|}
\hline Forms of Capital & Habitus: Operating Factors & Outcomes for Female Autonomy \\
\hline $\begin{array}{l}\text { Human Capital } \\
\text { and Cultural } \\
\text { Capital }\end{array}$ & $\begin{array}{l}\text { Valuing female and feminine } \\
\text { capital in private sphere } \\
\text { through education and } \\
\text { cultural capital (embodied } \\
\text { capital). }\end{array}$ & $\begin{array}{l}\text { Intergenerational Transmission } \\
\text { (IGT) Factors, mostly cultural } \\
\text { capital; active social norms that } \\
\text { constrain choices, mobility and } \\
\text { gender roles. }\end{array}$ \\
\hline \\
\hline $\begin{array}{l}\text { a. Movable assets } \\
\text { (e.g. cash, } \\
\text { jewellery) }\end{array}$ & Dowry practices. & $\begin{array}{l}\text { IGT of wealth; limited decision- } \\
\text { making due to patriarchal } \\
\text { practices. }\end{array}$ \\
\hline & $\begin{array}{l}\text { Matrilocal and matrilineal } \\
\text { practices, cultural capital } \\
\text { through joint/extended } \\
\text { family system. }\end{array}$ & $\begin{array}{l}\text { IGT of assets; higher bargaining } \\
\text { power; reduced domestic abuse: } \\
\text { seen as collective asset with less } \\
\text { control on economic decisions } \\
\text { and physical mobility. }\end{array}$ \\
\hline $\begin{array}{l}\text { c. Farmland as } \\
\text { asset }\end{array}$ & $\begin{array}{l}\text { Matrilineal practices, } \\
\text { although increased sale of } \\
\text { farmland reduces fallback. }\end{array}$ & $\begin{array}{l}\text { IGT of asset, control over income, } \\
\text { and decision-making; reduced } \\
\text { domestic abuse; fallback for } \\
\text { social support. }\end{array}$ \\
\hline $\begin{array}{l}\text { d. Paid } \\
\text { employment }\end{array}$ & $\begin{array}{l}\text { Female literacy, agency, } \\
\text { increased social capital } \\
\text { (increased emotional }\end{array}$ & $\begin{array}{l}\text { IGT of economic and cultural } \\
\text { capital, presence in public sphere, } \\
\text { access and control over income, }\end{array}$ \\
\hline & 100 & $\begin{array}{l}\text { increased decision-making in } \\
\text { private and public spheres; } \\
\text { enhanced social support and } \\
\text { confidence and physical mobility. }\end{array}$ \\
\hline Social Capital & $\begin{array}{l}\text { IGT; SHGs, collective } \\
\text { participation, institutional } \\
\text { support; gender equality } \\
\text { in public sphere; reducing } \\
\text { caste and class inequalities. }\end{array}$ & $\begin{array}{l}\text { IGT of capital; presence and } \\
\text { participation in public spheres; } \\
\text { increased awareness of social } \\
\text { rights; more commitment to } \\
\text { wider social goals such as } \\
\text { sustainable farming, food } \\
\text { cultivation and reduction in } \\
\text { farmland conversion. }\end{array}$ \\
\hline
\end{tabular}

However, a lack of immovable assets for them, such as land or a house, may increase the emotional capital of women through the intensity of emotions, feelings and aspirations.

Females gaining property ownership through inheritance can bring increased income and some control (Allendorf, 2007) to households, but it is often a collective asset with no individual decision-making power being bestowed in the context of matrilocal and matrilineal practices.

Women with fewer immovable assets (e.g. landless labourers) may not enjoy autonomy such as decision-making in the households but their participation in collective networks such as SHGs increase social capital, networks, presence and participation in the public sphere, impacting on their levels of confidence. Examples of the benefits of group farming include an increase in food crop cultivation, 
an increased autonomy in the public sphere as well as achievement of social and development goals by reducing land transfers, and an impact on sustainable farming and collective bargaining power. However, this may increase economic patriarchy through increased work for women, higher levels of debt drawn from SHGs, more rivalry within groups etc. Overall, ownership and control of economic assets increases the inter-generational transfer of capital by improving the value of female and feminine capital in the private sphere. Thus, a combination of economic capital and access to independent forms of capital such as paid employment and social networks is more significant as this also aids collective bargaining power, achievements of wider social goals and gender equality.

\section{Conclusions}

Policy makers and development practitioners expect that women's autonomy in the household, exercised through their levels of bargaining power, will affect key development outcomes such as the health and education of children and the well-being of the women themselves (see Doss et al., 2008). However, women's autonomy is dependent on gendered norms and practices shaped by the habitus and access to different forms of capital. Thus Bourdieu's contribution to sociology has provided a broad understanding of how social actors operate within relation to difference, power and domination. In simple terms, Bourdieu's (1984) relational framework posits a series of connections: one's practice is tied to one's habitus; one's habitus is tied to one's relative capital; and one's relative capital is tied to the field in which one operates. This framework can be applied using notions of work, capital and power in semi-rural farm livelihoods. While women in semirural contexts are, to a certain degree, endowed with good levels of female capital (primarily human and cultural capital such as education, cultural practices, etc.), their access to and control of economic capital is often subject to gender and social norms (Arun, 2012). Increasingly evident forms of patriarchy now place more importance on forms of feminine and embodied capital, and they do this through gendered perceptions and behaviours on notions of work, access to capital and their outcomes. Unnithan-Kumar (1997) points out that, despite contrasts between north and south India, these regions share common trajectories of change such as trends in sanskritisation. For example, there have been negative changes for women, such as the spread of dowry practices as well as the deepening of son preference and consequent masculinisation of landed rural households, but these have been coupled with positive changes, such as closing gender gaps in education and increased well-being. Traditional conceptions of work and material conditions in agriculture may render gender relations invisible, but the lens of relational intersectionality identifies the hegemony of cultural and social practices through kinship, caste and family, while gender and social differences interact with each other to produce systems of inequality and asymmetries. Thus, by activating gendered habitus, we see gender relations both as being constituted by and as helping to constitute these practices and ideologies, and this happens in their interaction with other structures of social hierarchy such as class, caste and race. 
The matrilineal system of descent gives Nair women ownership of property and may allow them greater bargaining power within the household, but their participation in decision-making and physical mobility is limited. Also, ownership of land must be distinguished from control of land. Women contribute to the household in terms of land inheritance, dowry, gold and help from the natal home or from paid work in poorer households. As Sharma (1980) states, the power women wielded and their importance in determining household policy depended on factors quite other than their capacity to work or generate income. Social norms dictate women's work, their extent of participation in paid work and their access to resources; reciprocally, these three reinforce social norms about docile and gendered bodies. Thus, women's role in production explains much about their social roles. Regarding access to property in South Asia, Agarwal (1995) states that the gender gap in the ownership and control of property is the single most important contributor to the gender gap in economic well-being, social status and empowerment. Women's presence and participation in the public sphere is enabled through efforts on collective farming through Kudumbashree, which could work towards the meaningful involvement of women in key farm activities. Such a form of women's collective participation is an important political and economic space for women, particularly those from landless and marginal rural households. Yet women's status vis-à-vis economic capital in farm households has been key to the increased diversity and complexity in social relations brought about by changes to agrarian practices and wider social changes throughout society.

\section{Notes}

1 Unitary models of households were based on the idea that household members act in pursuit of joint goals; thus, the single-family welfare function is justified because an altruistic household head acts according to the preferences of all family members.

2 According to Sen (1987), co-operative conflict involves members of the household facing two types of problems simultaneously - one involving co-operation (i.e. is adding to total availability), the other conflict (i.e. dividing total availability among the members of the household).

3 Agarwal (1997) sets out four elements of norms that affect bargaining power: norms set limits to bargaining; norms are a determinant of or constraint to bargaining power; norms affect the process of bargaining; and social norms themselves constitute a factor to be bargained over.

4 For example, historians often cite the ancient text of Manusmrithi that accords similar status to women and Shudras in terms of according restrictions or rights that affect their bargaining power within and beyond the household.

5 Socio-economic groups placed lower in the caste hierarchy in India seek upward mobility by emulating the customs and practices of the upper or dominant castes, for example, the withdrawal of women from paid work.

6 In the early twentieth century, Sethu Lakshmi Bayi initiated measures to liberate women from the devadasi (temple prostitutes) system (and protect their incomes). However these measures occurred in parallel with the decline of the matrilineal system which dictated social norms that upheld patriarchical notions of dutiful wife and mother, covering of breasts, and widowhood (rather than polyandry), thus destroying social frameworks that provided protection, autonomy and dignity. 


\section{Matriliny and kinship}

7 To clarify, 1 hectare of farmland is equivalent to 2.47 acres, and on an average most of the households in the region had approximately 0.50 acres of holding.

8 The Janasree Sustainable Development Mission was launched in 2008 by the United Democratic Front (UDF)-led government to organise groups of households through micro-enterprises and community insurance schemes. This scheme is very similar to the Kudumbashree scheme, and both schemes have been accused of having vested politicised interests.

\section{References}

Agarwal, B. (1995). A Field of One's Own: Gender and Land Rights in South Asia. Cambridge: Cambridge University Press.

Agarwal, B. (1997). “"Bargaining” and gender relations: Within and beyond the household.' Feminist Economics, 3(1), pp. 1-51.

Agarwal, B. (2010). Gender and Green Governance: The Political Economy of Women's Presence Within and Beyond Community Forestry. Oxford: Oxford University Press.

Agarwal, B. and Panda, P. K. (2007). 'Toward freedom from domestic violence: The neglected obvious.' Journal of Human Development, 8(3), pp. 359-388.

Allendorf, K. (2007). “Do Women's Land Rights Promote Empowerment and Child Health in Nepal?" World Development, 35(11), 1975-1988.

Arun, S. (2012). 'We are farmers too: Agrarian change and gendered livelihoods in Kerala, South India.' Journal of Gender Studies, 21(3), pp. 271-284.

Arun, S., Annim, S. K. and Arun, T. G. (2013). 'Overcoming household shocks: Do assetaccumulation strategies matter.' Review of Social Economy, 71(3), pp. 281-305.

Bourdieu, P. (1979). 'Public opinion does not exist.' Communication and Class Struggle, 1, pp. 124-130.

Bourdieu, P. (1990). The Logic of Practice. California: Stanford University Press.

Bourdieu, P. (2001). Masculine Domination. California: Stanford University Press.

Bryceson, D. F. (2002). 'The scramble in Africa: Reorienting rural livelihoods.' World Development, 30(5), pp. 725-739.

Chari, S. (2004). Fraternal Capital: Peasant-Workers, Self-Made Men and Globalization in Provincial India. Stanford, CA: Stanford University Press.

Cloud, K. (1994). 'Women and agriculture: Household level analysis'. In: Borooah, R., Cloud, K., Seshadri, S., Saraswathi, T. S., Peterson, J. T. and Verma, A. (eds.), Capturing Complexity: An Interdisciplinary Look at Women, Households and Development, pp. 125-150. New Delhi: SAGE Publications.

Delphy, C. (1977). The Main Enemy a Materialist Analysis of Women's Oppression. London: Women's Research and Resources Centre Publications.

Dixon-Mueller, R. (1985). Women's Work in Third World Agriculture: Concepts and Indicators. Women, Work and Development Series 9. Geneva: ILO.

Doss, C. R., Grown, C. and Deere, C. D. (2008). 'Gender and asset ownership: A guide to collecting individual-level data.' World Bank Policy Research Working Paper 4704. Washington, DC: World Bank.

Dwyer D. H. and Bruce, J. (eds.). (1988). A Home Divided: Women and Income Control in the Third World. Stanford, CA: Stanford University Press.

Dyson, T. and Moore, M. (1983). 'On kinship structure, female autonomy, and demographic behavior in India.' Population and Development Review, 9(1), pp. 35-60.

Ellis, F. (2000). Rural Livelihoods and Diversity in Developing Countries. Oxford: Oxford University Press. 
Elson, D. (1994). 'Micro-meso-macro: Gender and economic analysis in the context of policy reform.' In: Bakker, I. (ed.), The Strategic Silence: Gender and Economic Policy, pp. 33-45. London: Zed Books.

Elson, D. (1995). Male Bias in the Development Process (2nd Edition). Manchester: Manchester University Press.

Floro, M. S. (1995). 'Economic restructuring, gender and allocation of time.' World Development, 23(11), pp. 1913-1929.

Folbre, N. (1986). 'Hearts and spades: Paradigms of household economics.' World Development, 14(2), pp. 245-255.

Fuller, C. J. (1975). 'The internal structure of the Nayar caste.' Journal of Anthropological Research, 31(4), pp. 283-312.

Government of Kerala. (2006). Adhikaram Janagalilekku. Ummanoor: Ummanoor Panchayat Report.

Government of Kerala. (2015). Economic Review. State Planning Board, Kerala. [Accessed on 24 August 2016] Available at: <http://spb.kerala.gov.in/index.php/economic-review/ er-2015.html>.

Gough, K. E. (1954). The Traditional Kinship System of the Nayars of Malabar. Cambridge: Harvard University Press.

Harris-White, B. and Heyer, J. (2010). The Comparative Political Economy of Development. Africa and South Asia. New York: Routledge.

Jain, D. (1997). 'Valuing work: Time as measure.' Economic and Political Weekly. [online]. 25 October, 31(43), pp. WS46-WS57.

Jeffrey, R. (1976). The Decline of Nayar Dominance: Society and Politics in Travancore, 1847-1908. London: Sussex University Press.

Kabeer, N. (1994). Reversed Realities: Gender Hierarchies in Development Thought. London: Verso Books.

Kabeer, N. and Van Anh, T. T. (2002). 'Leaving the rice fields, but not the countryside: Gender, diversifications and pro-poor growth in rural Vietnam.' In: Razavi, S. (ed.), Shifting Burdens: Gender and Agrarian Change Under Neo-Liberalism, pp. 109-150. Bloomfield: Kumarian Press.

Kandiyoti, D. (1998). 'Gender, power and contestation: Rethinking bargaining with patriarchy.' In: Jackson, C. and Pearson, R. (eds.), Feminist Visions of Development: Gender Analysis and Policy, pp. 135-152. London: Routledge.

Kepe, T. (2008). 'Beyond the numbers: Understanding the value of vegetation to rural livelihoods in Africa.' Geoforum, 39(2), pp. 958-968.

Krais, B. (2006). 'Gender, sociological theory and Bourdieu's sociology of practice.' Theory, Culture and Society, 23(6), pp. 119-134.

Kudumbashree (2016). 'History and background.' Online. Available at: www.kudumbashree.org/.

Lawler, S. (2004). 'Rules of engagement: Habitus, power and resistance.' In: Adkins, L. and Skeggs, B. (eds.), Feminism After Bourdieu, pp 110-128. Oxford: Blackwell.

Liddle, J. and Joshi, R. (1986). Daughters of Independence: Gender, Caste, and Class in India. London: Zed Books and Kali for Women.

Mencher, P. J. (1987). 'Women's work and poverty: Women's contribution to household maintenance in two regions of South India.' In: Dwyer, V. and Bruce, V. (eds.), A Home Divided: Women and Income Control in the Third World, pp. 99-119. Stanford, CA: Stanford University Press.

Menon, S. (1978). Cultural Heritage of Kerala: An Introduction. Kerala: East-West Publications. 


\section{Matriliny and kinship}

Mohanty, C. T. (1991). 'Cartographies of struggle: Third world women and the politics of feminism.' In: Mohanty, C. T., Russo, A. and Torres, L. (eds.), Third World Women and the Politics of Feminism, pp. 1-50. Indiana: Indiana University Press.

Moi, T. (1990). 'Feminism and postmodernism: Recent feminist criticism in the United States.' In: Lovell, T. (ed.), British Feminist Thought: A Reader, pp. 367-376. Oxford: Basil Blackwell.

Moser, C. O. N. (1993). Gender Planning and Development: Theory, Practice and training. London: Routledge.

Nair, K. N. and Menon, V. (2007). 'Distress debt and suicides among agrarian households: Findings from three village studies in Kerala.' Centre for Development Studies. Working Paper, No 397, Kerala. [Accessed on 24 August 2013] Available at: $<$ http://econpapers. repec.org/paper/esswpaper/id_3a1586.html>.

Navarro, Z. (2006). 'In search of a cultural interpretation of power: The contribution of Pierre Bourdieu.' IDS Bulletin, 37(6), pp. 11-22.

Osella, F. and Osella, C. (2000). Social Mobility in Kerala: Modernity and Identity in Conflict. London: Pluto Press.

Palmer, I. (1991). 'Gender and population planning in adjustment of African economies: Planning for change - the informal sector.' Geneva: International Labour Organization.

Pollak, R. A. (1985). A Transaction Cost Approach to Families and Households. Journal of Economic Literature, 23(2), 581- 608

Razavi, S. (2002). Shifting Burdens: Gender and Agrarian Change Under Neo-Liberalism. Bloomfield: Kumarian Press.

Saradamoni, K. (1994). 'Women, Kerala and some development issues.' Economic and Political Weekly, 26(9), pp. 501-509.

Saradamoni, K. (1999). Matriliny Transformed: Family, Law and Ideology in Twentieth Century Travancore. New Delhi: SAGE Publications.

Sen, A. (1987). Gender and Co-Operative Conflicts: Wider Working Papers. Helsinki, Finland: World Institute of Development Economics Research.

Sharma, U. (1980). Women, Work and Property in North West India. London: Tavistock Publications.

Unnithan-Kumar, M. (1997). Identity, Gender and Poverty: New Perspectives on Caste and Tribe in Rajasthan. New York: Berghahn Books.

Uyl, M. D. (2000). 'Kinship and gender identity: Some notes on marumakkathayam in Kerala.' In: Böck, M. and Rao, A. (eds.), Culture, Creation, and Procreation: Concepts of Kinship in South Asian Practice, pp. 177-197. New York: Berghahn.

Whitehead, A. (1984). 'Men and women, kinship and property: some general issues.' In: Hirschon, R. (ed.), Women and Property: Women as Property, pp. 176-192. St. Martin's Press.

Yunez-Naude, A. and Taylor, E. J. (2001). 'The determinants of non-farm activities and incomes of rural households in Mexico with emphasis on education.' World Development, 29(3), pp. 561-572. 


\section{$5 \quad$ ICT and gender capital (a)work}

\section{Introduction}

Debates on feminist-technology relations have long argued for a move away from a technology of determinism to one of social determinism where technology is constitutive of social relations (see Cockburn and Omrod, 1993; Howcroft and Richardson, 2009; Wajcman, 2010; Trauth, 2013). Much research investigates the gender-technology relationship within gender and development debates (e.g. Arun and Arun, 2002; Arun et al., 2007; Basi, 2009; Mirchandani, 2009; Patel, 2010; Gurumurthy, n.d.). These debates have relied on the term information and communication technologies (ICTs), one that is mostly used in development debates regarding applying information and communication technologies to social, economic and political development, as has been popularized within ICT4D (ICT for Development) discussions. This study uses ICT to explore ICTs and development debates, particularly those concerning the digital divide, the digital gender divide and development goals.

The global economy and society have been transformed by the production (and consumption) of digital technologies, and these have affected gender relations in many ways such as work, leisure, identities, consumption and networking. Nevertheless, women's overall gains from working in the ICTs sector is questionable (Howcroft and Richardson, 2009). This chapter shows how ICT-related work spheres act as sites of change, control and resistance, and it demonstrates the need to consider the emotional and embodied dimensions of women's lived experiences. Through a Bourdieusian analysis, it reconceptualizes ICT work practices as a powerful emotionally embedded work practice that structures social behaviours, but simultaneously inflects gendered identities. Feminist scholars have long "appropriated" Bourdieusian theories through concepts such as "capital" and "habitus", and these concepts have seen a renewed link with materiality, as discussed in Chapter 2. Further, the value of different capitals has become tied to their context and had consequences for social reproduction (Moi, 1990: Skeggs, 1997). Furthermore, emotional capital is increasingly becoming the focus of analysis across numerous disciplines such as education, professional settings and social practice (Reay, 2004; Gillies, 2006; Zembylas, 2007; Hutchison, 2012), which are (mostly) possessed (and exercised on) by women, so they are seen as 
gendered capital. As this study brings out, the levels of emotional capitals possessed and their outcomes are different for women within a similar field such as ICT. ICT work-related domains help unravel the complexity of fields and how these fields overlap, undermine and reinforce each other' they also open up space for the struggle over the value of various forms of capital and their convertibility into symbolic capital (see McNay, 1999). The operation of such fields relates to Bourdieu (1984, pp. 94)'s observation: 'This is why the same practices may receive opposite meanings and values in different fields, in different configurations or in opposing sectors of the same field.' This chapter specifically focuses on the impact of ICTs within Kerala's economy and society, particularly on women's empowerment through diverse working practices. It first reviews relevant literature on women and the impact of ICTs both on them and on related aspects (e.g. social relations, flexibility and gendered nature of work). It then discusses the mutual shaping and reproduction of gendered habitus and capital in a knowledge economy before providing conclusions.

\section{Women, work and ICTs: transforming capital and habitus}

Work and occupational-related social mobility have widely been discussed in sociological debates on class, particularly in the UK. These have traced the decline of traditional industries, the rise of the middle class and the feminisation of work that have led to the polarisation of class structures. All of which these trends fuelled a war on "class" in the 1990s (Saunders, 1997; Goldthorpe, 2000 ) and stimulated analyses of the role of cultural capital in social divisions (Bourdieu, 1984; Savage et al., 2013). As Jenkins (1992) says, habitus adapts and reproduces but is influenced by historical, social and cultural contexts; Bourdieu (2000, pp. 82-83) even assigned more plasticity to habitus as it constitutes 'a system of lasting, transposable dispositions which, integrating past experiences, functions at every moment as a matrix of perceptions, appreciations, and actions'. Habitus is therefore dynamic and generative of its own possibilities, so it is not wholly structured (Swartz, 1997; McNay, 1999). Feminists' research on work in Western contexts have focused much on the gendered nature of flexibility, particularly in the context of technology and skills. The plethora of feminist scholarship on gender and technology, particularly work practices in the field of IT, shows how IT is not seen to be a level playing field for men and women (Howcroft and Richardson, 2009). As Gurumurthy (n.d.) notes, two discourses capture the gender and ICTs narrative: one focusses on women's entry barriers to employment, their enterprises and their access to markets; the other explores how ICTs can enhance public service delivery, including how development institutions and practitioners can better deliver basic capabilities to women's well-being. This chapter is more concerned with the former and considers Wajcman's (2004) point about how the need to focus on the production of technology because new technologies create "new" societies through their importance on capital, particularly human capital.

Feminist theories have produced important insights into the constitutive power of emotions in shaping social and cultural realities ${ }^{1}$ (see Reay, 2004). This work 
departs from psychological accounts of emotion and adopts a sociological framework that focuses on the social structures of individual identities, roles and actions under patriarchal capitalism. Nowotny (1981, pp. 148) uses the term "emotional capital" 2 as a form of social capital in the sense of social and cultural resources such as the "knowledge, contacts and relations as well as access to emotionally valued skills and assets, which hold within any social network characterized at least partly by affective ties'. However, there is limited attention on the use of emotional capital and labour within the field of IT work. This chapter will explore how emotional capital involves examining the gendered ways in which class is discursively produced (see Gillies, 2006). In particular, how do new technology work practices and aspirations for mobility through both material and social contexts shape emotional capital. Here, the term emotional capital concerns an embodied resource - a form that can benefit both those who are the recipients of the labour and those providing the labour. For Andrew (2015), emotions are produced and enacted within a framework of power relations, so they reflect inequalities of class, race and gender, which are perpetuated in knowledge-based societies where education and human capital interact with structural and material contexts.

Wajcman (2004) argues that the site of research on gender and technology should shift from those of consumption and representation to spheres of production in order to examine power relations through gendered systems and practices. Furthermore, an individualistic approach does not challenge the masculine culture of the IT sector, as it is predominated by a matrix of patriarchal norms that are subject to notions of gender, class, culture, sexuality and power. ${ }^{3}$ As Colley (2006, pp. 25) argues, women struggle to deploy their resources as capital because of the ways they are 'generally positioned as subordinate players in all fields', and because social location interacts with gender and generates different outcomes for women. Thus, class structures assume importance because mobilising capital is about power relationships as well as resources, and it is constrained by 'prior historical classificatory schemes of value' (Skeggs, 2004, pp. 75). The emotional aspect experienced through social relations and culture is increasingly adopted in areas of culture and society (Ahmed, 2004; Skeggs, 2004). Studies on women's increased visibility in IT work show that this new service sector has not revolutionalized women's lives, though it has indeed altered household relations (Basi, 2009; Patel, 2010), so it seems that mere access to material gains through work are insufficient for challenging patriarchal forces. Women's entry into this sector has therefore created new status relations through the burgeoning middle classes, obviating concerns about caste and kinship relations (Upadhya and Vasavi, 2008; D’Mello, 2009), but creating improved household incomes and mobilities (Kelkar and Nathan, 2002). However, there is a caveat regarding the homogenizing effects of such global work practices (D’Mello, 2009; Patel, 2010) as a Foucauldian notion of power based on wider social relations and inequalities. It is therefore important to discern if agents are able to make use of their capitals in the sense of activating and transforming them to bring about social change both for themselves and for others. This chapter focuses on how different forms of capital are activated within the IT work field, and how these capitals interact with material 
and gendered contexts to pursue outcomes that are constitutive of economic and social relations. The context and impact of activation of capital within different ICT work environments in Kerala is explored as this is critical in a human capitalendowed state, particularly for women.

\section{ICTs in India and Kerala}

India's efforts in accelerating towards an information or knowledge economy have seen an increasing drive for an informatisation-based strategy. This strategy has had a direct impact on ICTs in terms of job creation and the labour process regarding producing hardware, software and related technologies, and an indirect impact regarding the diffusion or consumption of ICTs in other sectors and services (see Arun et al., 2007). The combined Information Technology (IT) sector and Business Process Management (BPM) industry has been cited as one of the country's fastest-growing development areas and even a miracle in terms of economic reforms, as India now has a dominant position in the global IT industry with 55 per cent market share. The Indian IT-BPM industry accounts for revenues of USD 146 billion, with the domestic segment accounting for USD 48 billion in 2015 (NASSCOM, 2016).

The industry's relative share in India's GDP is 9.5 per cent, and it is a main catalyst of growth as it offsets more than 70 per cent of India's oil import bill and attracts a major share of foreign investments into the country (NASSCOM, 2016). Recent economic growth agendas such as Digital India and Make in India have helped drive a vision of a technology-enabled India. Over the years, India's software industry has gained a sustainable competitive advantage in the world market because of the competency and credibility of their personnel, fluency in English, relatively lower salaries, supportive government policies and improved infrastructure (Rothboeck et al., 2001; Arun and Arun, 2002; Mascarenhas, 2010). Overall, the industry continues to be a net employment generator, particularly as a diverse private-sector employer, with a direct workforce nearing 3.5 million women forming over 34 per cent of this workforce - and effecting over 10 million indirect jobs (NASSCOM, 2016). With many comparative advantages in costs and human capital, Indian call centres, or Business BPOs, have seen significant growth as now around 500 foreign companies outsource work to 300 phone-based call centres in India, employing 200,000 people (Datta, 2004; Mirchandani, 2009). The domestic segment of call centres, which serve Indian customers in banking, insurance and financial services, is slightly different in terms of its lower salaries, smaller workplaces and poor employment practices (Taylor et al., 2014). More generally, one study comparing women's and men's levels of economic empowerment using indicators relating to pay, anti-discrimination policies, employee gender ratio, and senior female management and leadership placed India 115th out of 128 countries (Aquirre et al., 2012). The average age of employees in this sector increased from 25 in 2000 to 30 in 2015 (The Economic Times, 2015). Although accurate figures on the gendered breakdown of employment is officially unavailable, it is estimated that $40-70$ per cent of workers in BPOs are women, with 
women mainly working in telemarketing or data processing services (Gothoskar, 2000; Ng and Mitter, 2005).

Figures from the Global Gender Gap Report 2010, which gives country rankings on gender parity, show that India is among the lowest for gender and pay parity among BRIC economies (Hausmann et al., 2010). In Kerala, the continued emphasis on ICTs as an engine for industrial growth and employment is reflected in its ICT policy on robust infrastructure, which focusses on upgradation of the quality of human resources and the formation of the State Electronics Technology Park (Technopark) (GOK, 2015), both of which provide a competitive business environment in the state. In all, Technopark hosts 350 information technology (IT) and information technology enabled services (ITES) companies, employing over 50,000 IT professionals (Technopark, 2017).

Markedly different from the neo-liberal style of technology firms, the wellcited case of Kudumbashree (meaning "prosperity of family through women") - a women-oriented participatory and integrated approach to fight poverty - is an atypical case study where ICTs have contributed to the economic empowerment of poor women and households (Heeks and Arun, 2015). The enterprise activity of such Neighbourhood Help Groups (NHG), or ayalkootams (comprising women from poor families and including a range of activities), have one of their innovative aspects as using IT and ITES in enterprises. In all, support has been provided for the setting up of 28,566 individual enterprises ${ }^{4}$ and 11,377 group enterprises from both rural and urban areas (Kudumbashree, 2016). Research into the impact of such ICT initiatives on poor livelihoods and women's empowerment has shown that poverty-reduction strategies for employment, enterprise creation and the empowerment of marginalised groups are a form of social outsourcing where the aims of business and development can be brought together through new forms of entrepreneurship (Heeks and Arun, 2015). Presently, 74 IT units throughout the state engage in data-processing work for state government departments, digitalisation of BPL data and ration cards, and birth registration cards (Kudumbashree, 2016). A recent development is the formation of e-Seva Kendra through the IT unit, which the Motor Vehicles Department (MVD) launched to provide rapid services for motorists through the Regional Transport Office (RTO) and Sub-RTO (Kudumbashree, 2016). In terms of social location, women from such units do fall below the poverty line as they are classified as "below poverty line" despite many having a good level of human capital, including technical qualifications; specifically, almost all have degrees or pre-degree qualifications (equivalent to 10 years' education).

Another albeit relatively recent ICT-related professional opportunity - a typical case of flexible working - is online tutoring, which engages in global student learning and is undertaken through personal one-to-one interaction between a learner and a professional tutor over a secure web environment using a home PC, web browser and broadband Internet connection (Prahalad and Krishnan, 2008). The rise in such online tutoring centres has allowed numerous IT-trained tutors in India to provide e-tuition to students (mostly ages 12-16) from countries such as the US, UK and Australia, maximizing benefits from time-distance differences. Using 
virtual whiteboard workspace enables the tutor and the student to engage in more interactive learning, particularly in mathematics, as it allows work with simulations and animations to maximize the learning experience. In many ways, then, both the economy and society have been transformed by the production (and consumption) of digital technologies, but these have also impacted gender relations. Such ICT-related work spheres act as sites of change, control and resistance, but they require consideration regarding the emotional and embodied dimensions of their lived work experiences, which simultaneously inflects their gendered identities.

\section{Gendered capital in IT work fields: empirical evidence}

Much has been written about the work practices within knowledge-intensive sectors in relation to middle-class women in urban India (see Arun and Arun, 2002; D’Mello, 2009; Mirchandani, 2009); this usually involves narratives of young, educated, middle-class women's experiences of social structures and how they are shaped by the flows of neo-liberal policies, globalisation and modernity in India. However the effects of such new technologies on other lower socio-economic classes is less known. This chapter focuses on work practices in such knowledgeintensive work environments but for a range of women, especially their flexibility and mobility, types of capital generated (and invested) and the impact of these on their social lives. Evidence on the above effects in the form of women's lived experiences is the major feature of the study, and this evidence comes from diverse sources. It is based on a purposive sampling method of 35 IT workers in different sectors of the ICT industry: 12 were software professionals from different software firms; 7 were from BPOs; 5 were from ICT-based Kudumbashree enterprises; and 6 were IT-based online tutors. Most sample respondents were based in the capital, Thiruvananthapuram. The online tutors were working for firms based in Ernakulam, one of the cities with many online tuition centres. The Kudumbashree workers were from the longest-established Kudumbashree ICT units in the capital city of Thiruvananthapuram. The fieldwork was conducted throughout several phases in 2016 and involved a mix of structured and unstructured interviews, building on research from Arun et al., (2007) which compared experiences of women working across a range of IT sectors. The interviews via email and Skype discussions with 3 online tutors and 2 software professionals was also supplemented, with a diverse sample of women from different backgrounds in relation to class, caste and regions, the study helped to discern a range of effects through work in a range of market and non-market-based contexts to facilitate intersectionality of class, caste and gender, to transcend relations beyond the public-private binary, and to unravel economic and social relations. The findings from all these interviews shed light on wider discussions about changing gender roles and relations within Kerala's ICT sector.

\section{Activating capital/s in the ICT field}

Work in the knowledge-intensive ICT sector, irrespective of type of activity, is typically characterized not only by long, flexible working hours, frequent travel 
and project-based work but also potential for high rates of earnings. The acceleration of the growth in IT, particularly software production, has increased demand for staff in software design, development, application and maintenance (Arun and Arun, 2002; D'Mello, 2010), and staff are usually recruited based on their levels of human capital. Graduates with engineering qualifications from all specialisations or with an equivalent degree in Computer Applications reflect the high levels of qualifications of both men and women in Kerala working in this industry.

Estimates of monthly earnings in this sector range from between ₹ $1,088,145$ for a typical project manager in Information Technology to ₹318,006 for a software developer (Payscale, 2013). Yet, evidence shows while a mid-level IT manager earns an average salary of USD 41,213, a similar Swiss IT employee earns over four times that amount, demonstrating that Indian IT companies are among the worst pay masters (The Hindu Online, 2015). Furthermore, DataQuest's Best Employer Survey 2012 demonstrated that the percentage of women employed in the IT industry in India actually decreased from 26 per cent in 2010 to 22 per cent in 2012. Our discussions on earnings showed that starting-point salaries for men and women were mostly the same, particularly for younger staff, but with progression and over time women fell behind men. This decline is because of career breaks on account of child birth, need for flexibility to conform to long and flexible working cultures, and other working conditions. Similarly, Padmanabhan (2011) found earning parity among younger men and women but also that this changes with age. Many women felt that, despite possessing higher levels of human capitals and technical skills and with pay and economic rewards being based on periodical appraisal systems, their performance depended on a range of individualized factors. Such practices of the "internal labour market" lead to a more pronounced "individualisation" of risk with increased insecurities in relation not only to job stability but also to long-term equity. Furthermore, issues of workplace harassment from male colleagues were also reported, which discouraged women - particularly married women - from working in project groups that otherwise may have benefited their career progression.

In relation to economic earnings, online tutors took home an average of ₹6000, depending on number of classes and hours taught. Term time for schools in client countries was a key determinant of demand for work and pay, while school holidays affected overall income. Thus, instability of income was quite common; moreover, on several occasions students did not "appear" online for classes, but tutors were nevertheless expected to stay online, at a reduced pay, until the end of the session. Some felt that although teaching styles were similar to classroom experiences, lack of emotional and personal interaction with students and high levels of monitoring by management were negative features of online teaching. Yet learning styles within Western curricula, the social and cultural behavioural patterns of global students, and positive feedback from students for sessions were noted as empowering aspects of such work.

In contrast, despite a comparatively low level of educational qualifications of women in Kudumbashree IT units, this line of work has reinforced their economic and human capital in relation to technical skills and work in general. These IT units have developed computer operational skills, management skills and 
leadership skills in their roughly 750 female core members and have particularly helped women in gaining group leadership roles. Entrepreneurial traits were also developed through better understanding of balance sheets, cash flow, customers etc. If one looks at the overall IT sector, the human capital developed for this group of women may be confined to the relatively low-skill end of the spectrum but still represents a vital foot on the IT work ladder for what had otherwise been poor, unemployed, semi-skilled women (Arun, Heeks and Morgan, 2007). Some IT units have moved up the value chain by adding web and software development work to their portfolio. In 2016, work through the e-Seva office within the RTO office in the capital was boosted. Set up with the support of the Motor Vehicles Department, the office directly helps motorists without online services at home or those that lack digital literacy with such needs as application and renewal of driving licenses etc. This has helped eliminate middle agents and has reduced transaction costs. However, it has also brought the group into direct confrontation with middle agents as well as employees, thus affecting the overall delivery of services (The Hindu Online, 2016). ${ }^{5}$

These IT units - through the institutional support of Kudumbashree as an incubator - have allowed women from disadvantaged backgrounds to break free from the traditional stereotypes of inequalities of power and value between "women's work" and "men's work". They have thus been able to at least initiate the breaking down of certain social, political and even institutional biases of gender inequality, though they still grapple with issues of economic and social inequality. Participants in the call centres felt quite devalued as they came into this line of work, when young and ambitious after gaining a degree in an IT-related subject, hoping to make a career in this field. Discourses on women's empowerment show that accumulating economic capital through earnings increases women's sense of identity and self-worth, their respect within the family and community, and sometimes their role in decision-making (Kabeer, 1994; Arun et al., 2007), though this may reflect high levels of erosion of emotional capital through stress and distress. As studies have shown, such group enterprises often bank upon "poor women's social capital" that is framed within poverty and empowerment debates (see Mayoux, 2001; Maclean, 2010). Kabeer (2008) defines empowerment as expanding people's ability to make strategic life choices in relation to three interrelated components: resources (enhancing the ability to make choices), agency (the ability to define one's goals and act on them) and achievements (outcomes of agency). Previous research has shown how issues of empowerment can be discerned through an asset approach to livelihoods (Arun et al., 2007). In part, one can see it as a combination of human capital itself - related to capitals one possesses - and its interaction with other forms of capital, such as social capital, which relates to the access to sources of power that particular social relations bring. However, the hidden aspect would be the high levels of emotional capital required to manage stress, the competing demands of the IT sector and social norms (see Table 5.1), which may be different for various IT work practices.

New technology arenas such as new media are where increased insecurities and stressful working conditions show a shift to the individualisation of risk 


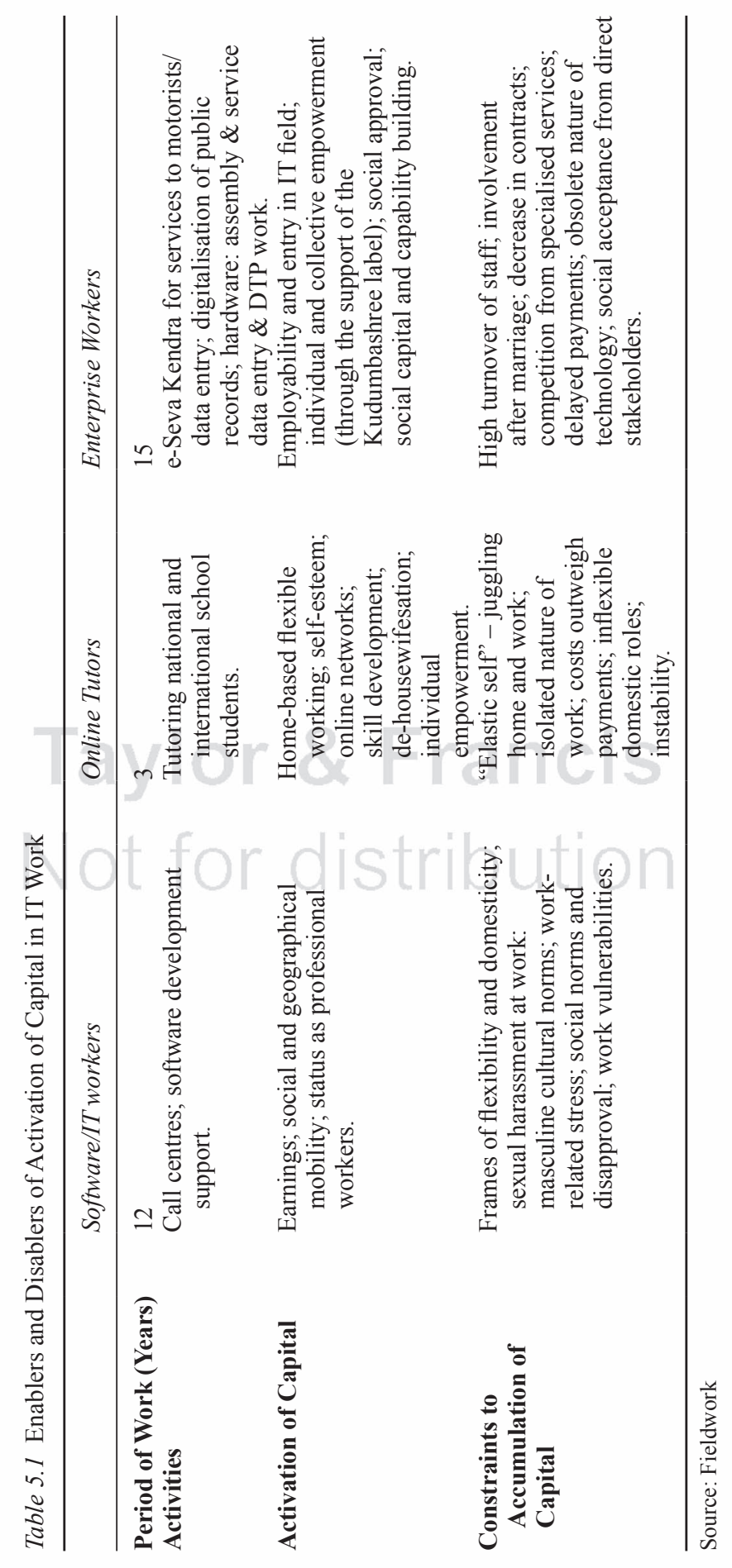


(Banks and Milestone, 2011). Our discussion with the IT professional women showed how the image of an IT professional has waned, given the realities of a job that is seen to be 'low end, catering to caring and listening to the angry, abusive Western client' (Interviews), and work cases of sorting mundane tasks such as booking tickets, confirming travel itineraries and chasing up routine enquiries. Those in domestic call centres complained of more stressful working conditions and lower pay compared with those in transnational call centres. As seen from Table 5.1, constraints to activation of capital were gendered, cultural and social. Thus, women felt more emotional stress when facing blatant expressions of anger and harassment from customers, peers and organisations. As 36-year-old Reshma said: 'This is more so because we are women as the abuse and impatience can be more towards women than men.' Seen within a Bourdieusian framework, the existence and the value of emotional capital are highly contested in such marketrelated work fields - for example, the IT field brings out high levels of competition, pressure and flexible work demands where there are different ways in which these forces privilege different capitals within them.

\section{Flexibility as practice: engendering emotions, caring and anxiety}

With long working hours being the norm for IT work, women from all categories of work felt that work "revolved" around family and caring responsibilities. For those in software production, their workings hours usually exceeded the normal 8 hours per day, and some even worked on some Saturdays to meet tight project deadlines, which happened increasingly during the economic slowdown as numerous projects became more competitive. In particular for women in the formal IT work environment, meeting traditional expectations of roles in the family (e.g. mothering and "housewifisation") was harder than it was for men. For example, homework was one area that mothers were expected to take care of in this context, and indeed many others. Besides spending time after work, many women resorted to paying highly priced tuition fees for their children. At times, men took the children to these centres, or grandparents offered help. In other situations, private tutors provided tuition at home (charging high rates per subject each month). As Shreeja (age 40, mother of 2) said: 'Working mothers are judged by their children's academic performance, as people are quick to say that ambitious, highachieving working women often neglect their children.' Clearly, the emotional labour and capital involved in providing home tuition for children is not only very demanding for working mothers in a practical sense but also a psychological sense. All this often had a knock-on effect as these expectations were built into appraisal and promotional systems; perhaps consequently, or at least with this playing some part of their decision-making process, women sometimes opted to avoid going for promotion and instead preferred to spend time tutoring their children during key assessment times. Furthermore, near-to-total presenteeism from male and unmarried women colleagues has made teams extremely competitive and has added further stress to working environments, not to mention affecting 
working hours. The recent climate of recession in the West, hostility towards outsourcing IT jobs and the imminent fear of losing jobs exerted even more pressure on decisions to "stay on" despite workers having long and flexible working hours.

As Deepa (42, Nair caste), a software engineer, said, 'We are seen as socially privileged mothers based on our class, caste and occupation, but the levels of anxiety are never understood.' In this study, working mothers who were constantly involved in educational care work of their children experienced anxiety and erosion of emotional capital. Working professional mothers with reasonably high levels of economic, cultural and social capital worried and cared intensely about their children's achievements in school and college admissions. Reay (2000) previously argued that middle-class mothers with access to traditional capitals sometimes worried too much about their children's schooling, but as seen here this is because working professional women are judged by their children's educational success, demonstrable through "intensive caring" through cultural notions of "grihasta" (housewife) and not just their own individual achievements.

In this sample, mothers who were engaged in online tutoring took a more active role from engaged care to control, shown by expending higher levels of emotional energy and intensive caring through more skills testing, additional tutoring etc. For Andrew (2015), emotions are produced and enacted within a framework of power relations so they reflect inequalities of class, race and gender. Emotional labour is different from emotional capital. Emotional labour - first theorised by Hochschild (1983) - involves particular daily performances of emotion, primarily by women. Emotional capital consists of the skills and dispositions that may become embodied via performances of emotional labour under certain conditions. The term emotional capital emphasises an embodied resource and a form of capital that can benefit both those who are the recipients of the labour and those providing the labour.

The sample of women - unemployed prior to their involvement with Kudumbashree - do possess high levels of human capital in terms of educational qualifications and further technical training. However, the abovementioned Kudumbashree initiative has provided them with important additional competencies as though they have taken on roles that have traditionally been the preserve of men or in high technology firms, such as the Technopark in the capital. Yet the problem of activating emotional capital without access to other capitals was obvious. For example, initial resistance from the women's own families and communities, such as apprehensions about late working hours and demands on physical mobilities, eventually gave way to social acceptance and self-esteem of their families, when referring to these women as "IT" workers. In a few cases, such long working hours created hostilities both within and outside the home. Sujatha's (age 39) experience shows this:

During the first few months of work, my husband was unhappy with me returning late in the evenings; on one occasion, he even refused to open the door, and I had to wait for a long time before he relented. Not long before that, some neighbours had commented on my "late appearances", which made him 
quite suspicious, and wanted me to quit the job and was only convinced when the Kudumbashree officials discussed the nature of our work.

Research has indicated that self-employed mothers find it difficult to manage work and family responsibilities (Ekinsmyth, 2011). The term "mumpreneurs" concerns entrepreneurs who are driven largely by the desire to achieve "work life harmony" from the blurred boundary between the roles of "mother" and that of "businesswoman". Such complications largely derive from the social norms and patriarchal ideologies that dictate how women who work during unsociable hours are met with resistance and social disapproval; in many cases, such conflict has caused women to drop out of entrepreneurships. A few women had some emotional support from their husbands, yet their relative poverty, caste status and lack of knowledge of advanced IT skills meant they had to exert far greater effort to achieve a level of success at work than women from middle-class backgrounds routinely achieved. This also meant that they had to invest more time into their own children's achievements, leaving insufficient space for one's own emotional well-being (O’Brien, 2008).

Thus, flexibility in the workplace, loosely referred to as allowing a balance of work and family commitments, was largely judged in terms of "total availability" and "presenteeism" - indicating a commitment to work and the organisation but also meaning that the lived-in experiences of workers, through work-life issues, could be accounted for (Lewis and Cooper, 2005). Women's working patterns, largely based around reproductive and caring roles, did not fit in with the normative basis for such working arrangements and often required an embodied presence, meaning they often fell short of the standards of their ideal male colleagues (Lewis and Cooper, 2005). Some gave up careers in software development because of the pressures from travelling and the long hours, and they instead moved to routine jobs in support roles. Typical cases include those who moved from software to online tuition, call centres etc. A respondent, 23, who moved to online tuition, commented: 'I have swapped flexi-hours in my previous work to flexi-hours throughout the night, while working online, but at least I don't have to travel to work.' Again the concept of flexibility is useful in call centre work, as time and working patterns suit clients in the selected countries. As Mirchandani (2009) writes about transnational call centres, the feminisation of service work that accords a 'professional and technical status' reifies both the gendered norms and the colonial hierarchies that do not consider employees' family responsibilities but are instead relegated to the private sphere and deemed of only individual concern.

The professionalisation of women's work has increased domestic outsourcing, which has given women's professional occupations continuity. Most immediately this outsourcing usually falls to the extended family, such as grandparents who help with household chores, child care and school runs, especially during intense times such as school holidays and assessment periods. More domestic help also comes via recruitment through formal agencies for household cleaning and food preparation. It costs around ₹3000 (part-time) to ₹12,000 (full-time) for 
outsourced local service providers to do chores such as ironing. Time taken for food preparation was reduced through domestic help and using local takeaways that suit children's tastes (burgers, pizzas etc). The nature of ancillary industries for domestic outsourcing, for example use of take-away meals, employing parttime cooks, eating out and family holidays, also increased because of increased disposable income and more consumerism.

One member, Usha (age 42) of the Kudumbashree Unit summed up this impact: 'Of course you may earn slightly more in paid employment, but we have attained increased levels of both personal and professional skills such as human resource management, marketing, personal skills, not to mention the flexibility that this livelihood permits.' In this case, then, flexibility is not an external factor that constrains women's lives but something inherent that these women control and value. Skegg's (1997) study of working-class women reveals the emotional politics of class regarding how social and cultural positioning generates denial, dis-identification and dis-simulation rather than adjustment. Similarly, Friedman (2012) deploys a Bourdeusian analysis to illustrate intra-occupational disadvantage, showing how those from working-class backgrounds experience a class ceiling despite experiencing similar social mobility to their counterparts. He draws on the Bourdieusian conception of social space being constructed along the three dimensions of 'volume of capital, composition to capital and change in these over time', and he shows how social, cultural and emotional challenges persist for those aspiring to be upwardly mobile. In all, there are limits to how aspirations for mobility are realised for different groups of women in IT fields. For example, many women in call centres who worked in software production have had to move to low-end jobs such as quality control to combine and meet their care and work demands. Flexibility evidently also means mobility within jobs for these women, but alas it is mostly downward. The women also faced long working hours though they have been helped by their extended families or even their neighbours.

While consumers and motorists are respectful to these women, some officials and other employees do not exhibit the same respect to "Kudumbashree women". As one of the women, Rani (45, ST caste), says:

We have had this resistance and lack of respect for a long time from different quarters, not to mention social acceptance of our caste - we are quite used to it. In our society, we tend to respect professions usually comprised of middleclass (and caste) groups such as doctors, engineers and IT professionals, while we are not positioned in the same category due to our background and our gender, although we possess adequate levels of education and IT skills.

Working from home for Online Tutors carries challenges regarding juggling work and home in the same space, but social attitudes to such work was an important aspect. Of course, time management was quite a challenge for online tutors, and their long hours into the night affected household work, the sharing of this time with their husbands and their need to get their children to school (e.g. the children were used to their mothers serving breakfast on the table). Furthermore, a "working 
mother" was still an "illusion". Women had to tend to social calls and look after visitors because of expectations of "housewifisation", particularly by close families and relatives who did not take this type of homeworking as seriously as other forms of employment. For women themselves, the feeling that they did not have 'to go out' to work at times made them feel as if they were not working. Some of them adapted by "embodied practices" (extra effort in applying their make-up and presenting their bodily appearance), similar to power dressing to embody a working culture.

\section{Social capital and reworking habitus}

Generally, all women in the sample rely on a range of networks that help their working lives. Primarily it is the interventionist role of extended families in childcare and domestic responsibilities that allows women to focus on their careers and professional lives more. Although the effect of an "old-boys' network" still operates within masculine cultures, women tend to form their own networks and circles through friendship buddies, and these have been strengthened through such virtual technology as mobiles, Facebook and emails. Technology has helped women in three main ways: giving them a sense of inclusion in work and their social life, which gives a sense of identity; providing support in a range of situations both personally and in work situations, such as dealing with stress and conflicts; and furthering career enhancement through sharing information that helps with work matters, such as in preparing for interviews and appraisals or improving work practices. In many ways, these social networks are a form of enhanced social capital. As a specific example, online tutors found emails and online chatting with colleagues the most useful means of achieving support and helping them overcome feelings of alienation from work colleagues and peers. They used personal email addresses to counteract surveillance from official email systems. The nature of such benefits, as noted, partly relate to information and networking on pay practices or other opportunities, which have led to higher confidence, gaining work opportunities through or "accrued or translated social capital".

The findings also point to women's own perception of work and achievement through personal and professional network-building which stimulated a sense of confidence in them, and to some extent altered gender relations. For example, in cases where women see themselves as entrepreneurs (of Kudumbashree units) and take on leadership and managerial roles, they confidently exercised the power to hire and manage men as employees. Notions of empowerment also entered community networks, where women felt that contact from local panchayat offices, schools and political representatives such as councillors is important for social capital or networks. This contact benefited women in that it improved household welfare by helping women, for example, obtain ration cards, gain school admissions, get approval for personal loans and secure jobs for close relatives - all of which led to improved respect in their homes, neighbourhoods and communities. Their links with not only key business stakeholders were also strengthened through new and existing connections with state officials but also with business and institutional ones, for example, suppliers of IT equipment and 
their public-sector customers. A few women moved into local political roles in the panchayat, which is further evidence of political empowerment. In 2010 alone, 11,773 women contested the local panchayat elections; out of these, 5,485 won their seats (Kudumbashree, 2016). Such an experience itself allowed the development of personal skills, social capital and political awareness.

Common parlance regarding "belonging" to India's IT sector concerns Western, modern, imperial and global belongings and identities, but the sector is also equated to economic benefits for those with appropriate qualifications and for highly skilled people as well as top-end salaries, power dressing, a global lifestyle through frequent travelling, use of the English language and other Western tendencies. Such practices have not only transformed pay and working conditions across the sector, and indeed other sectors, but also ushered in a new era of social practices by changing forms of socialisation and IT consumption (for pleasure and for leisure). For example, India has seen increased acceptance of consuming alcohol as well as Western forms of entertainment, cultures and lifestyles, so the country now sees more beer parlours, dance clubs, pubs, gyms and bodybuilding shops, fast food outlets such as McDonalds, Burger King and Pizza Hut, and shopping malls with a range of global and national shopping chains. All this could be seen as homogenized global consumption - the McDonaldization thesis (Ritzer, 2011). But from another perspective the location and preponderance of such services in close proximity to IT companies suggests it is merely catering to this high-income group and others concentrated in cities and regional poles around such technology parks. These changing social practices in urban India have implications for everyday secondary socialialisation practices, class relations, and notions of masculinity and femininity. Women's autonomy and their career ambitions are sometimes interpreted as evidence of Westernisation leading to conflicts (Basi, 2009; Radhakrishnan, 2009). Recent studies on women in white-collar service employment in India tend to utilize passive acts of resistance to challenge gender inequalities in the workplace, suggesting that the concept of empowerment needs to include a greater focus on everyday resistance (Bezbaruah, 2012). Literature on women's entrepreneurship shows how "mumpreneurship" often blurs the boundary between the roles of "mother" and "businesswoman", and it demands that nontraditional work involving working (at times with male colleagues) and travelling during unsociable hours are no longer met with patriarchal responses that subsequently further dictate social "norms" and lead to familial and social disapproval that "encourages" women to drop out of such entrepreneurships.

As Rekha (age 34, a software professional) states:

All of this also transforms gender practices where close intimacy is developed through work and social interactions, changing lifestyle through widespread acceptance of the consumption of alcohol, smoking, dancing and adapting to Western style of dressing, e.g. jeans, short skirts and shorts. Working together for a longer time and spending unsociable hours together means we should learn to be one - boys and girls fighting or competing with each other is just like in our school playgrounds. 
However, such close encounters had ramifications for social relations concerning developing close intimacy between men and women. Breaks from traditional arranged marriages, increased divorces, extramarital affairs and re-marriages are becoming quite common among workers in the IT professional fields, as evidenced in interviewees' shared experiences and in stories about their friends that emerged in our interviews. Furthermore, media reports of increased divorce rates among IT professionals were common as they seemingly have less personal involvement in their own personal relationships, leading to suspicion among partners - as demonstrated by their partners hacking emails (SiliconIndia, 2011). Some reported increased harassment in the workplace, which strained working and personal relationships. Further, cases of fanatic nationalism and moral policing have led to attacks on girls and youth groups across many states in India.

In contrast, women from the Kudumbashree Units experienced the effects of socialisation differently, with many seemingly to have benefited from increased confidence through dealing with and speaking to men, both as co-workers and clients - something that was missing from their primary and secondary modes of socialisation. Radha (aged 45), one of the respondents, said:

But we also have now moved to adopting more modern lifestyles through spending time in beauty parlours for facials, eyebrow shaping, and getting clothes for ourselves, which we have not dreamt of in the past. This gives such a sense of liberation and personal fulfilment, where our own earnings [human capital] are translated into cultural capital [through material, cultural and bodily pleasures].

There has been a change in habitus for these women from prior disadvantaged social backgrounds, which has come from different forms of capital being accumulated, embodied and activated through reworking social relations and gaining privilege and power. However, their new habitus may also be seen as relative, as the Kudumbashree women feel able to activate their capital in relation to women in their own social locations and other Kudumbashree women who are non-IT workers, but not in other traditional sectors such as catering. This is because they are "IT workers" - a label of prestige and status, though there are severe constraints on accumulating economic capital through factors such as delayed payments, high costs of technology and resistance within working environments. Similarly, the pressures on emotional capital are quite high, with a "class ceiling" despite relative social mobility. Specifically, in this case, women from disadvantaged backgrounds face constant battles due to the dynamics of group membership, and also because of a lack of adequate finance, continued resistance that affects morale and self-esteem, and institutional dependency on Kudumbashree. Yet these women are persistently acknowledged as "IT workers" who rely on their emotional capital in daily transactions. This shows that emotional capital emerges as a gendered resource, but a simultaneously rigid yet dynamic one that individuals possess and employ so that the struggles endured ultimately benefit their households and their children rather than themselves. This is alienated emotional 
capital (Reay, 2000; 2004; Hutchison, 2012), where women, through persistence and hard work, can afford a good education for their children and get help with private tutoring and admissions, and where these women's children often go on to gain professional degrees in medicine, dentistry, engineering and IT. As Friedman (2012) notes, there is constant social, cultural and emotional challenges for those women aspiring to be upwardly mobile.

\section{Conclusion}

Women's work within the knowledge economy is shaped by their ability to activate different forms of capital, involving human capital, emotional skills, knowledge and experiences. The unequal experiences of different groups of women in varied work environments are not only significant in any intersectional approach as they interact with but are also exacerbated by class (and caste status) relations. As other studies have shown, simply gaining access to the knowledge worksphere through paid work does not lead to women's empowerment (Patel, 2010) without significant change to the domestic division of labour (Fuller and Narasimhan, 2008).

Despite high levels of human capital and middle-class backgrounds, some women have not been able to break the glass ceiling because of the regimes of flexibility in market-oriented domains such as IT software production and work conditions within call centres. Such work leads to emotional burnout and alienation. Working middle-class mothers are framed within the gaze of educational performance of their children, with women increasingly engaged in intensive caring and emotional involvement. Similarly, women who pursue their working ambitions find it hard to tear apart the label of grihastha, or housewife, even whilst taking up online tutoring from their homes, as in this space they face domestic and work pressures simultaneously. Working women from disadvantaged backgrounds for various reasons (e.g. structural or material factors) who engaged in knowledge work through group enterprises face many emotional battles and wellbeing issues due to social acceptance, the nature of technological enterprises and institutional constraints. Nevertheless, the branding or label of IT work was a form of cultural capital that these women acquired, though much emotional capital was invested in terms of their own time, emotions and struggles in maintaining these enterprises. This perpetuates and reproduces differences both between men and women and between women and unequal outcomes through new technologyrelated work practices and neo-liberal environments.

Moreover, social (and gendered) identities in transnational sites of work are caught within debates on and changing notions of femininities (and indeed masculinities), so gender capital is challenged and shaped by Westernisation and Western imperialism, and to some extent nationalistic notions of bodily politics. From this study, more research into the changing roles of the lived experiences of women/gender situated in a broader working context is warranted rather than merely viewing women as a variable - as merely an "IT" worker framed within deterministic parameters. Such an examination of social processes can account for 


\section{ICT and gender capital@work}

differences and commonalities among women, contextualising them in everyday class and social relations rather than treating them as a "homogenized or decontextualised analytic".

\section{Notes}

1 Within the field of education and schooling, Reay (2004) emphasises the close relationships between educational success, emotional capital and emotional well-being in the family. She also discusses the importance of viewing emotional capital as an investment in others - highlighting the emotional costs of those involved but particularly of mothers.

2 The term emotional labour was first theorised by Hochschild (1983) and involves the daily performances of emotion (primarily by women) as key to work in the fields of technology and soft skills. Through her Marxist-feminist analysis in The Managed Heart: The Commercialization of Feeling, she argues that emotional work is subject to prescription and control by dominant groups.

3 Thus, a grave challenge remains in terms of situating women's experiences or even using "woman" as an analytical construct - avoiding any slippages into any essentialism (see Haraway, 1991; McRobbie, 1997; Trauth, 2006; Trauth, 2013).

4 The Kudumbashree units have four criteria regarding their ownership: full co-operative ownership and management and operation by women from below-the-poverty-line families; a group investment ranging from ₹ 5000 to ₹ 400,000; potential turnover of 2-10 times the initial capital investment; and the potential to raise a minimum of ₹2500-5000 monthly per member, by wage or profit (Arun et al., 2007).

5 The small office is a mere 150-square-foot cabin, with electricity provided free of cost to the e-Seva Kendra by the MVD. Other facilities like systems, scanners, photostat machine, internet connectivity and chairs have been installed by the Kudumbasree Mission. A sum of ₹20 is charged for each application and ₹2 for providing printouts.

\section{References}

Ahmed, S. (2004). 'Affective economies.' Social Text, 22(2), pp. 117-139.

Andrew, Y. (2015). 'I'm strong within myself: Gender, class and emotional capital in childcare.' British Journal of Sociology of Education, 36(5), pp. 651-668.

Aquirre, D., Hoteit, L., Rupp, C. and Sabbaugh, K. (2012). 'Empowering the third billion: Women and the world of work in 2012.' Booz \& Company. [Accessed on 19 August 2013] Available at: <www.booz.com/media/file/BoozCo_Empowering-theThird-Billion_Full-Report.pdf $>$.

Arun, S. and Arun, T. (2002). 'ICTs, gender and development: Women in software production in Kerala.' Journal of International Development, 14(1), pp. 3950.

Arun, S., Heeks, R. and Morgan, S. (2007). 'ICT initiatives, women and work: Reproducing or changing gender inequalities.' In: Ghadially, R. (ed.), Urban Women in Contemporary India: A Reader, pp. 297-308. New Delhi: SAGE Publications.

Banks, M. and Milestone, K. (2011). Individualization, gender and cultural work. Gender, Work \& Organization, 18(1), pp. 73-89.

Basi, J. T. (2009). Women, Identity and India's Call Centre Industry. London: Routledge.

Bezbaruah, S. (2012). 'Gender inequalities in India's new service economy: A case study of the banking sector' (Doctoral dissertation). Queen Mary University of London. Available at: $<$ https://qmro.qmul.ac.uk/jspui/handle/123456789/2479>. 
Bourdieu, P. (1984). Distinction: A Social Critique of the Judgement of Taste. Cambridge MA and London: Harvard University Press.

Bourdieu, P. (2000). Pierre Bourdieu. London: SAGE Publications.

Cockburn, C. and Ormrod, S. (1993). Gender and Technology in the Making. London: SAGE Publications.

Colley, H. (2006). 'Learning to labour with feeling: Class, gender and emotion in childcare education and training.' Contemporary Issues in Early Childhood, 7(1), pp. 15-29.

Cottingham, M. D. (2016). 'Theorizing emotional capital.' Theory and Society, 45(5), pp. 451-470.

Datta, R. C. (2004). 'Worker and work: A case study of an international call centre in India.' 22nd International Labour Process Conference, 5-7 April, University of Amsterdam, The Netherlands.

D'Cruz, P. and Noronha, E. (2008). 'Doing emotional labour: The experiences of Indian call centre agents.' Global Business Review, 9(1), pp. 131-147.

D'Mello, M. (20010). 'Are you married? Exploring gender in a global workplace in India'. In: Howcroft, D. and Richardson, H. (eds.), Work and Life in the Global Economy: A Gendered Analysis of Service Work, pp. 52-77. Basingstoke: Palgrave Macmillan.

The Economic Times. (2015). 'Focus on lateral hiring increases average employee age in Infosys, TCS, other IT firms; freshers join startups.' [Accessed on 5 August 2016] Available at: <http://articles.economictimes.indiatimes.com/2015-08-05/news/65243292_1_ average-age-non-linear-growth-secondlargest-software-company-infosys $>$.

Ekinsmyth, C. (2011). 'Challenging the boundaries of entrepreneurship: The spatialities and practices of UK.' Geoforum, 42(1), pp. 104-114.

Friedman, S. (2012). 'Cultural omnivores or culturally homeless? Exploring the shifting cultural identities of the upwardly mobile.' Poetics, 40(5), pp. 467-489.

Fuller, C. J. and Narasimhan, H. (2008). 'From landlords to software engineers: Migration and urbanization among Tamil Brahmans.' Comparative Studies in Society and History, 50(01), pp. 170-196.

Gillies, V. (2006). 'Working class mothers and school life: Exploring the role of emotional capital.' Gender and Education, 18(3), pp. 281-293.

Goldthorpe, J. H. (2000). On Sociology: Numbers, Narratives, and the Integration of Research and Theory. Oxford: Oxford University Press.

Gothoskar, S. (2000). 'Teleworking and gender.' Economic and Political Weekly, 35(26), pp. 2293-2298.

Government of Kerala (GoK) (2015). 'Economic review.' State Planning Board: Kerala. [Accessed January 2017] Available at: <http://spb.kerala.gov.in/images/er/er15/index. html>.

Gurumurthy, A. (n.d.). 'Gender, development and digital technologies: Elements of a practitioners framework.' UNICEF. Office of Research Innocenti. [Accessed December 2016] Available at: <www.unicef-irc.org/article/1004/>.

Haraway, D. (1991). Simians, cyborgs, and women. The reinvention of nature. New York: Routledge.

Hausmann, R., Tyson, L. D. and Zahidi, S. (2010). 'World Economic Forum (WEF).' The Global Gender Gap Report. [Accessed on 19 August 2013] Available at: <http://www3. weforum.org/docs/WEF_GenderGap_Report_2010.pdf $>$.

Heeks, R., and Arun, S. (2010). Social Outsourcing as a Development Tool. The Impact of Outsourcing IT Services to Women's Social Enterprises in Kerala. International Development, 22, pp. 441-454. 


\section{ICT and gender capital@work}

The Hindu Online. (2015). 'Indian IT Firms among the world's worst paymasters.' [Accessed January 2017] Available at: <www.thehindu.com/business/indian-it-firmsamong-worlds-worst-paymasters/article7673581.ece>. September 21. New Delhi.

The Hindu Online. (2016). E-Seva Kendra Battling problems. September 16. [Accessed June 2017] Available at: <www.thehindu.com/news/cities/Thiruvananthapuram/e-SevaKendra-battling-problems/article14381821.ece>

Hochschild, A. (1983). The Managed Heart: The Commercialization of Feeling. Berkeley: University of California Press.

Howcroft, D. and Richardson, H. (eds.). (2010). Work and Life in the Global Economy: A Gendered Analysis of Service Work. Basingstoke: Palgrave Macmillan.

Hutchison, K. (2012). 'A labour of love: Mothers, emotional capital and homework.' Gender and Education, 24(2), pp. 195-212.

Jenkins, R. (1992). Bourdieu. London: Routledge.

Kabeer, N. (1994). Reversed Realities: Gender Hierarchies in Development Thought. London: Verso.

Kabeer, N. (2008). 'Paid work, women's empowerment and gender justice: Critical pathways of social change.' Working Paper 3: Brighton: IDS.

Kelkar, G. and Nathan, D. (2002). 'Gender relations and technological change in Asia.' Current Sociology, 50(3), pp. 427-441.

Kudumbashree. (2016). 'History and background.' Available at: <www.kudumbashree.org/> .

Lewis, S. and Cooper, C. L. (2005). Work-Life Integration: Case Studies of Organisational Change. Chichester: John Wiley \& Sons.

Maclean, K. (2010). 'Capitalizing on women's social capital? Women-targeted microfinance in Bolivia.' Development and Change, 41(3), pp. 495-515.

Mayoux, L. (2001). 'Tackling the down side: Social capital, women's empowerment and micro-finance in Cameroon.' Development and Change, 32(3), pp. 435-464.

Mascarenhas, R. C. (2010). India's Silicon Plateau. Hyderabad: Orient Blackswann.

McNay, L. (1999). 'Gender, habitus and the field: Pierre Bourdieu and the limits of reflexivity.' Theory, Culture and Society, 16(1), pp. 95-117.

Mirchandani, K. (2010). 'Gendered Hierarchies in Transnational Call Centres.' In: Howcroft, D. and Richardson, H. (eds.), Work and Life in the Global Economy, pp. 78-98. Basingstoke: Palgrave McMillan.

Mirchandani, K. (2009). Transnationalism in Indian Call Centres. In: Thite, M. and Russell, B. (eds.), The Next Available Operator. New Delhi: SAGE Publications.

McRobbie, A. (1997). 'More! New sexualities in girls' and women's magazines'. In: McRobbie, A. (ed.), Back to Reality? Social Experience and Cultural Studies, pp. 190-209. Manchester and New York: Manchester University Press.

Moi, T. (1990). 'Feminism and postmodernism: Recent feminist criticism in the United States.' In: Lovell, T. (ed.), British Feminist Thought: A Reader, pp. 367-376. Oxford: Basil Blackwell.

NASSCOM. (2016). 'Indian IT - BPO services.' Available at: < www.nasscom.in/it-services $>$ /

$\mathrm{Ng}, \mathrm{C}$. and Mitter, S. (2005). 'Valuing women's voices: Call center workers in Malaysia and India.' Gender, Technology and Development, 9(2), pp. 209-233.

Nowotny, H. (1981). 'Women in public life in Australia.' In: Fuchs Epstein, C. and Laub Coser, R. (eds.), Access to Power: Cross-National Studies of Women and Elites, pp. 149-165. London: George Allen \& Unwin.

O'Brien, M. (2008). 'Gendered capital: Emotional capital and mothers' care work in education.' British Journal of Sociology of Education, 29(2), pp. 137-148. 
Padmanabhan, N. (2011). 'Understanding gender equality in the software industry of kerala through the capability approach.' [online] 19 March. Economic and Political Weekly, 46(12), pp. 70-75.

Patel, R. (2010). Working the Night Shift: Women in India's Call Center Industry. Stanford: Stanford University Press.

Payscale (2013). Average Salaries in India by Job. Available at: www.payscale.com/ research/IN/Country=India/Salary

Prahalad, C. K. and Krishnan, M. S. (2008). The New Age of Innovation: Driving Cocreated Value Through Global Networks. New York: McGraw Hill Professional.

Radhakrishnan, S. (2009). 'Professional women, good families: Respectable femininity and the cultural politics of a "New" India.' Qualitative Sociology, 32(2), pp. 195-212.

Reay, D. (2000). 'A useful extension of Bourdieu's conceptual framework? Emotional capital as a way of understanding mothers' involvement in their children's education?' The Sociological Review, 48(4), pp. 568-585.

Reay, D. (2004). 'It's all becoming a habitus: Beyond the habitual use of habitus in educational research.' British Journal of Sociology of Education, 25(4), pp. 431-444.

Ritzer, G. (2011). The McDonaldization of Society (6th Edition). London: SAGE Publications.

Rothboeck, S., Vijaybhaskar, M. and Gayatri, V. (2001). Labor in the Indian Economy: The Case of the Indian Software Labor Market. New Delhi: ILO.

Saunders, P. (1997). 'Social mobility in Britain: An empirical evaluation of two competing explanations.' Sociology, 31(2), pp. 261-288.

Savage, M., Devine, F., Cunningham, N., Taylor, M., Li, Y., Hjellbrekke, J., Le Roux, B., Friedman, S. and Miles, A. (2013). 'A new model of social class? Findings from the BBC's Great British Class Survey experiment.' Sociology, 47(2), pp. 219-250.

Swartz, D. (1997). Power and Culture: The Sociology of Pierre Bourdieu. Chicago: The University of Chicago Press.

Skeggs, B. (1997). 'Classifying practices: Representations, capitals and recognitions.' In Mahony, P. and Zmroczek, C. (eds.), Class Matters: 'Working-Class Women's Perspectives on Social Class', pp. 123-139. London: Taylor \& Francis.

Skeggs, B. (2004). Class, Self, Culture. London: Routledge.

SiliconIndia (2011). 'Divorce rate high among Indian Techies.' September 11. [Accessed December 2016] Available at: <www.siliconindia.com/shownews/Divorce_Rate_High_ Among_Indian_Techies-nid-90969-cid-1.html >.

Taylor, P., D'Cruz, P., Noronha, E. and Scholarios, D. (2014). 'From boom to where? The impact of crisis on work and employment in Indian BPO.' New Technology, Work and Employment, 29(2), pp. 105-123.

Technopark (2017). 'Technopark, Trivandrum, India: Harmony at work.' [Accessed January 2017] Available at: <www.technopark.org/>.

Trauth, E. M. (ed.). (2006). Encyclopedia of Gender and Information Technology. Hershey, PA: Idea Group Publishing. Trauth, E. M. (2013). 'The role of theory in gender and information systems research.' Information and Organization, 23(4), pp. 277-293.

Upadhya, C. and Vasavi, A. R. (2008). Outposts of the global information economy: Work and workers in India's outsourcing industry. New Delhi: Routledge.

Wajcman, J. (2004). Technofeminism. Cambridge: Polity.

Wajcman, J. (2010). 'Feminist theories of technology.' Cambridge Journal of Economics, 34(1), pp. 143-152. ISSN 0309-166X.

Zembylas, M. (2007). 'Emotional capital and education: Theoretical insights from Bourdieu.' British Journal of Educational Studies, 55(4), pp. 443-463. 


\section{Migrating gendered capital}

\section{Introduction}

With a long history of labour migration, Kerala is an illustrative example of migration dynamics operating in a global-local context. Following Bourdieu and Wacquant (1992), this chapter explores how individual agents enter the field to accumulate their capital and 'to transform, partially or completely, the immanent rules of the game' (ibid., p. 99). In doing so, it seeks to explain how such spatial flows disrupt and transform habitus clivé, or cleft habitus, and forms of capital in a global field. For Bourdieu, cultural habits and dispositions comprise a resource that is capable of generating profits but are potentially subject to monopolisation by individuals and groups; also, under appropriate conditions, they can be transmitted from one generation to the next (see Lareau and Weininger, 2003). The feminisation of migration from Kerala is mostly of skilled nurses, as 90 per cent of migrant nurses in India and in the Gulf are from Kerala (Nair and Percot, 2007; Walton-Roberts, 2012); furthermore, many such nurses have recently moved into Western care and health sectors (Arun, 2010). First, this chapter explores the concept of "migrating habitus" in relation to nursing and care work - along with implications for gender, race and class - before analysing findings from the primary research. The final section summarises the conclusions.

\section{Migration of gendered and classed habitus}

Women's participation in the complex fabric of global capitalism is fast changing, evidenced in trends within the family and in changes from unskilled migration to new and independent forms of migrant routes. These trends reflect not only the contradictions and complexities of women's lives but also brings redefined relations between migrants and families, markets and the state, and increasing integration into the global market and larger society. According to the United Nation's (2016) International Migration Report, the number of international migrants (persons living in a country other than where they were born) reached 244 million in 2015 globally - an increase of 71 million, or 41 per cent, compared with 2000. Nearly two thirds of all international migrants live in Europe (76 million) or Asia (75 million), with the female share of global international migration being around 48.2 per cent. The legacy of migration from Kerala is key 
to understanding migrants' behaviour, resilience and aspirations for social mobility. Kerala accounts for the largest proportion of remittances by such economic migration back to India, which in 2012 was the world's largest recipient country at $\$ 70$ billion (about ₹3.7 lakh crore) (Zacharaiah and Irudayarajan, 2012). Since the early twentieth century during colonisation, Kerala has witnessed several phases of outflows of labour that have been distinctive in terms of destinations, nature of skills, work and occupation; all been responses to demand from international labour markets. For example, the first generation of migrants in the early twentieth century largely consisted of semi-skilled workers to other South Asian regions. Domestic migration to cities has also been common, including a continual flow of skilled workers from medical and allied sectors to the Persian Gulf, the United States and Western Europe. The post-1991 period saw an acceleration of skilled migration through the emigration of qualified professionals such as engineers, doctors and IT (information technology) workers to global labour markets such as Europe and the United States. Many of these macro processes in the global and national contexts situate and shape structures that affect migrants' habitus as these can be embodied and adapted in the host sites (e.g. the UK). Global economic cycles have affected such trends, exacerbating both opportunities and vulnerabilities both for north - south as well as south - south migration trends. For example, the recent Nitaqat policy in Saudi Arabia affected Kerala as it sent 574,000 workers to Saudi Arabia, affecting remittances to the state. Similar trends on restricting migration can be seen through Brexit politics and policies in the UK. Clearly, then, mobilities not only provide opportunities through global flows of remittances, goods and services but also expose vulnerabilities, insecurities and risks, and all these have gendered implications for individuals, the economy and the state.

An increasing phenomenon in international migration has been global northsouth migration, as seen in the International Migration Report (United Nations, 2016), with the percentage of females among all international migrants to Europe being highest (52.4 per cent). The increasing presence of non-European migrant workers in the Western labour market has been well documented (Kofman, 2000; George, 2005; Aboderin, 2007; Nair and Percot, 2007; Dyer et al., 2008; Arun, 2009; 2010; Kofman and Raghuram, 2010, 2015; Walton-Roberts, 2012), and there have been concerns about the global brain drain of skilled workers (Kittay et al., 2005). Between 1997 and 2006 the UK saw 100,000 Internationally Recruited Nurses (IRNs) admitted to the UK register (Buchan et al., 2013) originating from nonWestern countries such as South Africa, Ghana, the Philippines and India. A recent Institute for Employment Studies (IES) study shows that, since the 2008 recession (specifically between 2009 and 2015), the proportion of foreign nurses in the UK has fluctuated around 12 per cent (Marangozov, Williams and Buchan, 2016).

Older research charted how caring work has been feminised and devalued based on gendered and bodily assumptions about care work (Hoschild, 1983). The increasing concentration of migrant women in the health and care sectors has exposed issues of classed, racialised and gendered hierarchies of work and status (see Dyer et al., 2008), with implications for the social reproduction of habitus and asymmetries in the wider spectrum of social relations as seen in this chapter. 
Studies based on historical, colonial, post-colonial and global reflections have drawn on trends in and the status of nursing in India (Jeffery, 1988; George, 2005; Nair and Percot, 2007). For example, Walton-Roberts (2012) refers to the practices of British colonialism and post-independence Western aid that structured a nursing education system and facilitated international nurse migration but also simultaneously devalued the professional status of Indian nurses. A long history of stigmatisation and devaluation of nursing and care as an occupation exists, with specific concerns including issues regarding professional status and autonomy (Allan et al., 2008; Dyer et al., 2008). The stigmatisation of nursing in India also relates to body work(Jeffrey, 1988; Nair and Percot, 2007), with further stigma and pollution framed within the religious-caste nexus. For example, as WaltonRoberts (2012) writes, the Christian community traditionally dominated nursing in Kerala because Christianity allegedly operated outside Hindu caste restrictions, where the nursing profession was historically constructed in low-caste terms (Jeffrey, 1988, cited in Walton-Roberts, 2012).

I use the Bourdieusian concepts of habitus and cultural capital to investigate the transformations and contestations of migrants' experience. This chapter is motivated by the observation that agents such as skilled migrants come with a set of resources or capital through the distinctive features of gendered migration from Kerala as well as the inherited or overlapping features with nursing as a "field". Following Skeggs (1991), this group of migrants bring levels of capital with them that can be accumulated, transferred or lost in new settings. Here, gender is a primary form of capital as gender capital, through its female and feminine forms, is, as a disposition, a form of capital (McCall, 1992; Laberge, 1995; Huppatz, 2012). Similarly, Erel (2010) argues that migration results in new ways of producing and re-producing (mobilising, enacting, validating) cultural capital that builds on rather than simply mirrors power relations of either the country of origin or the country of destination. In this study I explore data from qualitative research with 25 Kerala migrants based on a larger study of 50 migrants in the Greater Manchester area of the UK, which builds on Arun (2009; 2010). To explore the gendered formation of habitus and capital among Kerala nurses in the UK, respondents that are employed in the National Health Service (NHS) and lived in the UK for more than 10 years have been selected via a snowballing method. These women belong to the areas of Trafford, Northern Moor and Wythenshawe. Many have moved from Central Manchester to these areas on account of good schools in the Trafford borough. In-depth interviews were conducted with 25 respondents (17 women and eight men), at least 19 of them identified themselves as being in the "middle class" in Kerala, with their motivations for migrating being largely economic. The group represented diverse geographic locations in Kerala but also had work experience outside Kerala (Delhi, Punjab and countries in the Persian Gulf), and they had different religious backgrounds. Nineteen were Christians, five Hindus and one Muslim. Information was elicited on changing forms of habitus, contestations and accumulation of capital; mechanisms of monopolisation or domination by individuals and groups; and pathways of transmission between generations in an altered setting. 


\section{Migrating "Global Fields" and "Capital": some emerging issues}

For Bourdieu (1985, p. 724), a field is any social space with 'a set of objective power relations that impose themselves on all who enter the field and that are irreducible to the intentions of the individual agents or even to the direct interactions among the agents'. This notion of field framed within the nation has been extended to that of a "global" field of power, with agents "positioned" and "position-taking" within the field (Naidoo, 2004; Marginson, 2008). Global migration is thus a "global field" that relates to habitus, rules and games and in which dominant systems of distinction based on class, occupational prestige, gender, race and economic capital are contestable. Issues of international migration often raise deep-seated issues about work, equality and policy, resulting in diverse precarious working relationships (see McDowell, 2008) which affect both habitus and capital, for example, through recognition of qualifications or working conditions. For Walton-Roberts (2012), discursive processes devalue the status of female nurses who, though increasingly integrated into migrant networks that offer enhanced economic rewards, still have to contend with social processes that undermine their status. These are discussed below.

\section{Nursing as classed and racial habitus}

Within the UK health sector, labour market hierarchies and disadvantages particularly in terms of gender - have been discussed (Smith and MacKintosh, 2007). In all, rates of pay and division of labour are characterized by gender inequalities, and these have been exacerbated by the internationalisation of nursing. For many in the sample, the initial excitement and desire to work in the Western health sector had almost disappeared after a few years of actually experiencing this. Much evidence shows that qualified nurse migrants are located on the lower levels of the NHS grading pyramid (Smith and Mackintosh, 2007), with the "pecking order" prioritizing white British followed by Australian then South African, after which comes Asian then black, with black Caribbean followed by black African (Smith and Mackintosh, 2007). Many Indians felt they were pigeon-holed as "blacks" for exercises of diversity within employment and ethnic monitoring, while labelled "pakis" in hostile encounters with patients. Their "difference" therefore played an important role in their progression (Shields and Price, 2002). For many of them in the sample, who are proud of their colonial and Christian heritage, the term "black" itself was 'shocking' and 'distressing'; as one (male, 34) stated: 'Our status is undermined through institutional discourses on being officially referred to as "Black and Ethnic Minority [BME] staff".' This was also translated into lower status and classed conditions. For example, for those working in residential care homes, conditions were more difficult as these respondents spoke of their hardship and emotional dissatisfaction in undertaking basic care work. By engaging in "dirty bodily" work, they deemed their mundane activities of cleaning, bathing and feeding to be 
deskilling and degrading, yet they were compelled to do these by legal, economic and regulatory conditions - mainly to complete their registration process. One male worker (32) said: 'My wife is the main earner in the house, and for me to find a suitable position within the NHS like her would require appropriate qualifications and recognition through registration.' Thus, the period until they acquire official recognition seemed the most difficult as it involved personal and work tensions that seemingly undermined their social and economic autonomy.

However, the accelerated process of occupational licensing often "de-skills" migrants when they arrive in the UK, so the "brain drain" of skilled migrants does not necessarily translate into a "brain gain". As noted, occupational licensing strips educated and highly skilled overseas professionals in many fields of their professional (Standing, 2011). This is a typical example of the 'global precariat' (Standing, 2011) where migrant workers suffer subsequent loss in pay and status, and also are further affected by gender, ethnicity and age, lowering their overall class status, compared to their country of origin. Previous research has shown that global care chains are a prime example of female migrant labour workers' work and life experiences, which have altered gender roles, being further compounded with racialised experiences (see Arun, 2010). Although these workers have substantial qualifications and work experience in India, many initially hoped that their skills and experience would respectively develop and increase while working in the health and care sectors in the West.

Yet, participants accepted that working conditions were better in certain respects - for example, standardized and formal working hours, flexibility with shifts helping the balance between work and family life, including childcare, which in many ways translated into dignity of work practices and family life. Indeed, a few reported that nurses in India were disrespected and subject to harassment in the workplace by patients and their families, their own peers and other medical staff, and they had had low pay rates and stressful working conditions. This disrespect was related to how nursing is branded in terms of its occupational value and desirability in India. That is not to say that all this changed in the UK entirely, as social acceptance was also limited in the UK. Discussions showed that such workers are often faced with hostile behaviours and notions from patients and their families that international migrant workers have taken on "British jobs". With the abovementioned positive aspects came certain degrading aspects, as two participants explained:

Of course, working hours are less, and working conditions are good, but hostilities, discrimination and negative attitudes from some patients are degrading. I am staying on so that my children can get educated and get better jobs in this country.

(Female, 42, Grade E)

My work experience of 10 years in India is not recognized; I feel that I am devalued, as I have started at a low grade.

(Female, 45, Grade D) 
In addition, disappointment with working standards (in terms of both technology and skills) was rampant (Arun, 2009), as this observation shows:

Working standards are markedly poor in the NHS - for example, private hospitals in India were of higher technological standards but here there is more paperwork, structured routines and procedures rather than quality patient care.

(Female, 44, Grade E)

A recent study (Marangozov, Williams and Buchan, 2016) outlines numerous factors that characterize the current levels of staff recruitment in the UK NHS sector: (1) an increased demand for nurses caused by the post-Francis emphasis on safe staffing (2) an ageing nursing workforce with higher proportion of nurses aged 50 and over; 3 ) a poor level of retention of working nurses; (4) much stress and burnout strongly linked with intentions to leave; (5) the highest actual leaving rate being among younger and older age cohorts, with stress and burnout being particularly high in newly qualified nurses; (6) an increasing healthcare demand on the NHS to meet the needs of an ageing population, which is growing in size and experiencing more chronic disease. Thus, the staff recruitment concerns in relation to the NHS directly relate to increasing reliance on the international recruitment of nurses. Existing issues in relation to low morale, and devaluation of staff in the NHS sector, is arguably transferred to foreign-born nurses, who not only enter the sector with devalued capital (non-recognition of skills and qualifications) but face more stress and burnout and further experience discrimination through practices of everyday racism.

Consequently, the everyday experiences of economic migrants often embody discursive narratives through increased precarity as they juggle life-changing chances, changing immigration policies and hostile social attitudes to migrants. For Standing (2011), the "global precariat" is a result of neo-liberal and market fundamentalist economic policies, as mobilities affect social inclusion and traditional class hierarchies (Savage et al., 2013). Inferior notions of bodily work and the lower status of nursing in the originating context (India) also carried over into the new host context (UK). Nevertheless, a certain level of agency and change in habitus was also seen, where age played an important role as younger migrant women were more able to engage successfully in professional development. For example, two respondents managed to complete their Master's in Nursing, while one completed her $\mathrm{PhD}$. Such achievements were supported by the organisation and rewarded through progression in grades as well as endowing them with more senior and managerial responsibilities.

Evidently, experiences of work among the sample respondents varied. While some were demoralized by their experiences of discrimination, their experience and qualifications not being recognised, and poor working standards, others were successful in gaining professional development and career promotions. Furthermore, such workers' experiences must also be examined against motivations for migration. Some, such as those from Christian backgrounds, stated that they preferred to work in a Christian country where their religious values could be nourished within 
a wider context of greater freedom and liberation compared with their previous experiences of working in Persian Gulf countries. Another respondent (male, 29) admitted that although he has a middle-class background, where his parents were schoolteachers, he felt that his educational qualifications did not help him get a preferred occupation in Kerala, so instead he wanted to find similar opportunities in the UK that would enable him to enjoy a better standard of living. For example, he said:

Here, you can drive a latest car such as a BMW or Mercedes Benz and live in a decent house with an average salary, something that is unthinkable in Kerala. We can also afford to get a better level of education for our children, so their careers should be quite settled if we live here. There is too much hierarchy and competition in India for our kind of semi-professional jobs.

The aspirations of skilled young workers are reflected in the contemporary mobility of economic migrants responding to the demands of the global economy. Such mobilities impact on the global flows of remittances, particularly to Kerala which is already a "remittance" economy. However this also exposes vulnerabilities, insecurities and risks, which are accelerated through processes of global mobilities. Evidence from primary research highlights findings in relation to work in the global labour market, the practices and experiences of such work, gendered experiences (both masculine and feminine) and outcomes of many mobilities within a global-local nexus. These are elaborated on below.

\section{Transforming capital in a global field: rupturing gender capital}

Bourdieu and Wacquant (1992) emphasise the importance of individuals' various forms of capital (e.g. cultural, economic and social) further mediated by individuals' position-taking - that is, how they strategize to employ their capital. The structure and volume of capital must be contextualized with an individual's social trajectory (ibid.) of gaining and valorizing capital. This is particularly relevant for understanding migrants' uses of capital, as the temporal and geographic trajectories and dimensions of constituting and mobilising capital are key to understanding how migrants use them. A central notion in Bourdieu's theory is that different forms of capital (e.g. social, cultural, economic as well as symbolic) are interlinked. Indeed, what distinguishes mere cultural resources from cultural capital is that the latter is convertible into other forms of capital. In this work, all participants evidently possessed high levels of human capital - for example, 14 had graduate qualifications in nursing while others had a diploma or an equivalent, and a few had studied in private institutions to obtain their degrees. The spouses of these migrant nurses, who were not health workers themselves, possessed similar levels of qualifications in fields such as management, accountancy, business administration and information technology. Furthermore, most identified themselves as being generally middle class in Kerala, self-identified through their parent's occupation, lifestyle, household assets (e.g. land ownership) and 
education. Yet their motivations for migrating were largely economic, so they were strategically using their social capital and resources to leverage migration. Further, such independence from the state, and not requiring economic help to such migrants and their families reinforced through the neo-liberal agenda, has created and continues to reinforce the idea of the "good" vs "bad" migrant citizen (Standing, 2011; Root et al., 2014). The effects of austerity and hostile social attitudes after Brexit predicate on this moral view of the self-sufficient migrant, but in reality it tests the social ties, resources and resilience of individual migrants, their families and wider community networks (Root et al., 2014).

As Ballard (2004) notes, most economic migrants are not necessarily from poor sections, rather such groups invest in the process migration for success. Nursing, once seen as "devalued" work, was nevertheless taken on by young men and women, altering notions of feminine or masculine ${ }^{1}$ capital. One respondent (male, 39) said: 'Men take on feminine traits of work through their caring work, which at times is degrading work, and with less control and autonomy, although it was a deliberate choice in acquiring capital for social mobility.' They sought capital in this way because legal citizenship status within the UK relates to employment, so nursing work functions as a pull factor (Kofman, 2000; Ribeiro, 2008). Having attained certain levels of education and work experience, such migrants have been able to gain "formal" work in key sectors such as health and gain formal citizenship in the UK. Similarly, in strategically responding to the labour shortage in western European care sectors, both men and women deliberately chose nursing as an occupation for such purposes. To achieve this they spent, on average, two to four years in professional education in India, either in state training programmes or in private institutions. Entry to private institutions required capitation fees, which was again a deliberate choice for these young people, albeit financed by their families. Many were also able to finance the vast agency fees charged by recruitment agencies for employment in the NHS or nursing homes. Thus, global-local recruitment agencies are vital in the globalized labour market, which are constituted by neo-colonial processes as well as through economic transnationalisation (Sassen, 2011). Similarly, men who work as nurses prefer to marry someone in the same profession to accommodate the required lifestyle, complement familial roles and ensure steady incomes. Thus, gender represents an important economic and cultural capital among skilled migrants (Arun, 2009). Through economic gains and increased purchasing power, they can improve the living standards of their families back home, as they finance these through remittances and investments in land, business and house construction, thus boosting the consumerist culture in Kerala. In ways, cultural capital has transformed routes for economic capital.

Research often treats migrants' cultural capital as reified and ethnically bounded; it assumes migrants bring a set of cultural resources from the country of origin to the country of migration that either fit or do not fit (Erel, 2010). Formal recognition of migrants' qualifications, work experience and place of graduation is extremely important for foreign workers' status (Ribeiro, 2008). This research found that legal citizenship requirements were, to some extent, 
circumvented through direct recruitment, as it was then easy to obtain a four-year work-permit, after which permanent residency and formal citizenship could be obtained. Another way of gaining the right to work and citizenship was through a spousal dependant visa - this was a popular route to working or settling down in the UK.

In particular, gendered changes are obvious. Women's ability to gain both independent legal status to work in the UK and indeed the cultural capital that enables them to act as social agents in their own lives with their families and spouses challenges the existing class divisions in their places of origin, thereby exerting their agency in decision-making while expanding their control in social arenas (see Arun, 2010). This agency diminished the stigma towards nurses and increased their prospects in the marriage market (see George, 2005; Nair and Percot, 2007; Walton-Roberts, 2012). Studies have also shown how migration has a profound impact on gender relations in terms of marriage through both status and changing forms of dowry. For example, rather than challenge patriarchy, female migration can actually perpetuate elements of it through payment of different form of dowries, for example, enabling spouses to travel and work in the UK, or payment of higher dowries (Walton-Roberts, 2012). Arun (2009) finds that choice and agency play an important role in determining marriage proposals. One young woman (27, Grade E) revealed how 'through working here, some of us have been able to choose our partners, that too from professionally qualified men in Management, Business Studies and Information Technology'.

Family migration has never been unproblematic. Previously, women who joined their husbands faced social, religious or economic-legal constraints in the host society (Kofman, 2000). While IRNs, as the main family breadwinners, achieved a certain stability in their careers, male spouses faced obstacles in finding paid employment. There were high levels of underemployment for them because of non-recognition of qualifications from India (e.g. in teaching and management). In many ways this dampened their expectations of living in the West, where men were unable to carry out the traditional masculine role of being the main breadwinner so were often the secondary earner, sometimes even juggling several jobs. Notions of masculinity are subject to cultural interpretations, so it thus acknowledges Connell's (2005) concept of hegemonic masculinity, which highlights the multiplicity of masculine behaviour(s).

Furthermore, responsibilities of childcare dictated men's choice of economic route or employment (Arun, 2009) - an aspect previously characteristic of women's choice to undertake paid work among early migrant households. Men therefore took hourly-paid evening and weekend jobs such as in supermarkets or fast-food outlets. It was a reversal in gender roles whereby they took on childcare duties, staying at home to look after young children while women went to work, though in many cases this was a temporary measure until children went to school. But women also opted for flexible work arrangements to integrate childcare and spouses' modes of working. For example, almost all young mothers who returned to work after maternity leave took on the "long day" routine (i.e. 11 hours a day for three days a week). The high costs of childcare were the main 
reason for this, while in other households grandparents arrived temporarily from Kerala to look after them while both parents went to work, and to help with other household and childcare tasks for some part of the year. Family networks were consequently strengthened through these regular visits - as was bonding with grandchildren - and these networks are crucial for transnational work and lives within a local-global network. In general, flexibility and family networks were important to achieve a reasonably stable economic life as migrants. Osella and Osella's work (2000) showed how migrant men's moving away from home and taking on responsibilities reflected a transition from payanhood to manhood, but this transition pushes and indeed changes the parameters of manhood itself.

In other cases, age was a major factor in terms of flexibility in finding employment. Men over 40 found it hard to obtain jobs that suited their skills and previous work experience, while younger men were more flexible, making it easier for them to retrain for jobs as plumbers or electricians, or for them to adapt to work in call centres, hotel management and information technology. Frustrations among older men were common regarding their working experience as migrants. In this context, Connell's theorisation of gender relationship in a wider social context through affecting social structures and exploring conceptions of and practices in masculinity - shows how interlinked structures produce particular "gender orders" or "regimes" by using hegemonic masculinity. This social change enabled through female skilled migration, results in the emergence of men as their dependants, which then manifests in the phenomenon of 'de-masculinisation'. Thus, men take on more caring (feminine) roles; earn incomes through temporary, less skilled jobs, thus being the vulnerable or 'precariat' subject in the labour market. As seen from the interviews, men felt trapped within gendered and racialicised spheres amid mismatches between productive and reproductive roles within the household, as well as racialised and class-based hierarchy within the labour markets.

In at least seven households of our study, entrepreneurship was an economic route to livelihood that offered flexibility regarding childcare, working hours and income. Those who took up self-employment set up ethnic (Kerala/Malayalee) food and grocery stores, some specialising in the home delivery of groceries. Others set up travel agencies that catered to travellers to and from Kerala, while a few invested in food businesses such as takeaways, catering and restaurants. Immigrant entrepreneurship, particularly among ethnic minorities in the UK, has raised complex questions about race, class and citizenship. Immigrants have long resorted to entrepreneurship as an economic choice of livelihood, particularly within ethnic enclaves - from which they can gain many advantages such as employment, security and cultural support (Zhou, 2004). Such structures develop social and business networks (Waldinger, 1993). Approaches such as "mixed embeddedness" stress the significance of structural and cultural factors in ethnic entrepreneurship in relation to spatial, sectoral and cultural influences as well as those from markets and social networks (see, for example, Welter, 2011). The multiplicity and intersectionality of these contexts shape entrepreneurial practices. In such entrepreneurial activities, social networks were crucial as friends and relatives in the UK, Ireland, Europe, the Middle East and Kerala formed 
business networks for imports and the supply of products or services. Thus, social networks are important not only for migration but also for maintaining transnational links for economic purposes.

\section{Migrant capital beyond the nation}

Migrants created mechanisms of validation for their cultural capital through negotiating with the ethnic majority, migrant networks and the wider community. Migration-specific cultural capital often (re-)produced intra-migrant differentiations in gender, ethnicity and class when creating validation alternatives to national capital. Generally for this group of migrants, their diasporic attachment to their homeland remained important but the disempowering nature of migrant identities helped negotiate new forms of transnational attachments. Different types of networks were evidently developed at local, regional and global levels to strengthen their social and political status. While common networks involved transnational entrepreneurship using social and economic links within the UK, mainland Europe and Australia, some played an active role in community, social and religious associations within their transnational space. Erel (2010) writes about how ethnic capital draws on the intra-ethnic differentiations and hierarchies that conceptualise culture as ethnically bounded and assume a causal relationship between a group's cultural traits and economic performance. Ethnic and human capital approaches assume that ethnic group boundaries can be assigned straightforwardly. However, many scholars have argued that group boundaries are contested in struggles over who can define the content and boundaries of a group (Anthias, 2007; Yuval-Davis, 2006).

Most cultural, religious and political networks took a more organised form, forming sub-regional and sub-ethnic networks such as "Kerala" and "Malayalee", which developed through cultural associations (Arun, 2010). Women were less active in such formal networks, preferring social media or religious networks. They felt that their colonial heritage (through a Western model of education and knowledge of English) as well as their Christian heritage were good measures of cultural capital to convert to social (networks through local churches) and economic (employment and earnings) capital. However, visible racial identities and hegemony of whiteness served as forces of discrimination both in workplaces and within neighbourhoods. As McDowell (2008) points out, the distinctive features of the wave of migration that emerged from EU expansion were that whiteness and Christian heritage were deemed to be privileged while racialised identities were persistently problematic. We can see, then, that such flows of people, capital and resources allow the social construction of spaces and networks within localities and neighbourhoods - facilitated through common experiences and, at times, accelerated through negative experiences of exclusion.

Cyclical forms of migration are also increasing among skilled migrants. The post-2008 recession period affected many migrants through, for example, falls in house prices, instability of jobs and changes to immigration controls that exacerbated conditions for moving elsewhere. Inflows of non-UK nurses into the UK 
reduced, but this was alongside increased outflows to other countries (Buchan et al., 2013), making it more precarious. Evidence of such trends was also seen in our study sample, as almost all respondents knew someone who had moved to Australia or to the US to work in a similar sector. Twelve respondents were planning to move while three already had offers from other countries. But by gaining work experience in the UK health sector, thus gaining capital and by further obtaining British citizenship, these respondents had opportunities to move to countries such as Australia, where they could join many other colleagues who had already found jobs there. One (male, 37) said:

Once we have left our native country, we are in a state of flux where economic motivations drive us to forward migration. We look out for better pay and working conditions, weather, larger houses, socialization opportunities for children, work opportunities for male spouses who are not nurses, and increased opportunities for family migration such as to Australia.

These workers make informed choices about their professions, moving across borders easily with their attained economic and cultural capital gained in one host country before moving to the next. With the economic opportunities provided through such demand-driven migration, women have expanded their social control, decision-making and power, as demonstrated in their knowledge of and familiarity with the dynamics of global market forces. Such changes to gender roles also produces new forms of social and cultural practices through the interaction of local and global forces, which transcends social divisions such as class, ethnicity and gender.

\section{Inter-generational accumulation of capital}

As seen above, mobilities drive agents with a set of resources or forms of capital that they bring with them from their prior habitus, and these can be accumulated, transferred or lost in their new settings. The use of habitus clivé, or cleft habitus, when "conditions of existence" change throughout one's life, and dispositions are affected by dislocation (Friedman, 2016); and such changes also rupture habitus (Thatcher and Halvorsrdu, 2016). Thus, migrants' relation to capital reflects an active pursuit of social reproduction as both of these are transferred through inter-generational transfers of capital. Given how first generations of migrants experienced loss of certain capitals (e.g. devaluation of education and professional qualifications, hegemony of whiteness and racial discrimination - both in the workplace and local settings), migrant families act towards endowing and embodying their next generation with these very types of capital. These could also be classified as economic (money and assets), social (social relationships and networks) and cultural capitals through forms of embodied (by forming a British identity and with cultural dispositions of the mind and body that embody both Britishness and a Malayalee identity) capital. Capitals can also be objectified (cultural goods such as learning Kerala culture through travels, visits to 
Kerala) and institutionalised (academic credentials through not only mainstream education but also community learning through heritage classes in Malayalam, Sanskrit, classical dance and music). Here, agents call on their social capital of wider family and community members of both religious (including particular denominations) and cultural groups (see Crossley, 2001). Furthermore, economic migrants actively pursue forms of symbolic capital that are perceived and recognised as legitimate - for example, by associating with cultural organisations that legitimise cultural learning and other educational pursuits to maximize academic credentials, especially where such practices show how ethnic capital is intergenerationally transmitted. One of these is the importance of human capital, viz. literacy and education - a key derivative of the Kerala model that parents transfer to their children, irrespective of gender. Research on inter-generational transfer of capital is determined by unequal preferences on factors such as gender (Quisumbing, 2006). However, in our study we find support in how mothers' education and parenting skills had a positive link to children's educational involvement. Migrants are therefore keen to maximize educational and life chances for their children regarding choice of school, educating themselves about school league tables and exploring additional learning opportunities such as private tutoring (including online tutoring) and Kumon lessons in English and mathematics. In the interviews, it emerged that fathers spent more time taking children to additional classes so their children could perform well in the 11+ exams, and there was much parental involvement in choosing university degrees. In addition, families tried to enhance their social and cultural capital through non-financial resources via relationships with people and institutions such as schools, churches and community organisations that influence the inter-generational transfer of capital. Such interactions affect the accumulation and value of all forms of capital, particularly in their embodied and institutional forms, so it is not merely about pursuing economic and financial capital such as wealth, earnings and housing.

\section{Conclusion}

Evidence from Kerala migrants, particularly women (who are seen as embodied female capital), shows how they have been endowed with human and cultural capital, such as education, language and professional qualifications. They are indeed a valuable economic and social resource not only within Kerala but also in the global sphere, illustrating narratives of resilience, adaptation and transformation simultaneously rupturing and transforming "habitus clivé". The global demand for care workers in the Western health sector has allowed women from southern states such as Kerala to gain employment within the UK and subsequently to obtain British citizenship in their own right. Changes through global macro policies, institutional demands and the aspirations of individual actors have together impacted both global migration and on gendered experiences. Women have become active and key productive agents who embody capital as they transform not only their own lives but also those of their families and the localities where they reside. These narratives also help unfold how the nature of care work, a sector already marked by low pay and stressful working conditions, particularly along class and 
gendered lines, is cumulatively intensified by racialised hierarchies that present new challenges regarding how global migrants are constructed and viewed within these working practices. Such changes are caught in the barbed rhetoric of "British jobs for British workers", where in precarious situations economic migrants are crucial in some sectors but simultaneously perceived as "undesirable" and a threat to the local population in terms of work opportunities and welfare benefits. What we see is the resilience of such migrants, both men and women, in facing such covert and overt forms of opposition in their lived experiences.

However, recent policy changes, including tougher immigration controls, have affected the inflow of economic migrants into the UK. In particular, changes to programmes for overseas nurses intending to practise in the UK and the removal of main-entry clinical grades in the NHS from the Home Office shortage occupation list have affected the inflow of overseas workers into the health sector (Buchan et al., 2013). Furthermore, these mobilities not only change the identities of the migrant groups beyond the region/national context but also transform gender relations in wider social contexts - for example, transposing notions and constructions of masculinity and femininity in terms of power relations, division of work and gender roles. While male spouses who accompany their (migrant) wives evidently often find it difficult to obtain suitable work because of labour-market dynamics, new economic livelihoods are being created that allow flexibility and that circumvent exclusion in the paid labour market - a good example being business networks, which are circuits for exchange locally, regionally and globally.

One cannot deny that the mundane migrant's everyday experiences are ridged by gender, class and racial ideologies and practices that expose vulnerabilities and insecurities. With the forces of neo-liberal labour markets, women migrants are more vulnerable because of their legal status, their lack of social and family contacts, and their all-too-frequent status of being victims of exploitation and abuse, so measures are required to ensure migration is integrated into national and sectoral development policies, strategies and programmes (Kodoth and Varghese, 2012; United Nations, 2016). There should be due consideration to the linkages between migration and development policy agendas, particularly in the post-2015 development agenda, with a shift in the current position of migrants as mere agents of development to one as rights holders. The transformation of gender relations is happening in ways that exhibit trends of gendered capital through the feminisation of migration, the masculinisation of caring occupations and de-masculisation in general (see Arun, 2009). New identities and roles are therefore being forged through the nexus of the global and the local, and these are not only understood through the lens of global relationships but also performed, resisted, adapted and made more meaningful through global connections, cultural exchanges and interactions.

\section{Note}

1 Here, gender capital refers to female and feminine as well as male and masculine forms of capital. In general, nursing as an occupation is socially constructed as feminine, based on feminine traits such as caring and bodily work. The increase in the number of males 
undertaking nursing professions demonstrates how notions of masculinity are changing. However, in the sample there was evidence of men securing good career progression in this sector, showing how masculine traits are useful in the workplace. Nevertheless, more evidence is required on masculinity and masculine forms of gender capital in the Kerala context, and beyond the scope of this study.

\section{References}

Aboderin, I. (2007). 'Contexts, motives and experiences of Nigerian overseas nurses: Understanding links to globalization.' Journal of Clinical Nursing, 16(12), pp. 2237-2245.

Allan, H., Tschudin, V. and Horton, K. (2008). 'The devaluation of nursing: A position statement.' Nursing Ethics, 15(4), pp. 549-556.

Anthias, F. (2007). 'Ethnic ties: Social capital and the question of mobilisability.' The Sociological Review, 55(4), pp. 788-805.

Arun, S. (2010a). 'Caring Professionals: Global Migration and Gendered Cultural Economy.' In: Howcroft, D. and Richardson, H. (eds.), Work and Life in the Global Economy: A Gendered Analysis of Service Work, pp. 124-141. Basingstoke: Palgrave Macmillan.

Arun, S. (2010b). 'Caring” cosmopolitans and global migration: Plus ça change?' In: Raman, K. R. (ed.), Development, Democracy and the State: Critiquing the Kerala Model of Development, pp. 204-218. London: Routledge.

Ballard, R. (2004). 'A case of capital-rich under-development: The paradoxical consequences of successful transnational entrepreneurship from Mirpur.' In: Osella, F. and Gardner, K. (eds.), Migration, Modernity and Social Transformation in South Asia, pp. 25-58. New Delhi: SAGE Publications.

Bourdieu, P. (2000). Pierre Bourdieu. London: SAGE Publications.

Bourdieu, P. (1985). 'The market of symbolic goods.' Poetics, 14(1-2), pp. 13-44.

Bourdieu, P. and Wacquant, L. J. (1992). An Invitation to Reflexive Sociology. Chicago and London: University of Chicago Press.

Buchan, J., O'May, F. and Dussault, G. (2013). 'Nursing workforce policy and the economic crisis: A global overview.' Journal of Nursing Scholarship, 45(3), pp. 298-307.

Clayton, J., Crozier, G. and Reay, D. (2009). 'Home and away: Risk, familiarity and the multiple geographies of the higher education experience.' International Studies in Sociology of Education, 19(3-4), pp. 157-174.

Connell, R. (2005). Masculinities. Berkeley: University of California Press.

Crossley, N. (2001). The Social Body: Habit, Identity and Desire. London: SAGE Publications.

Dyer, S., McDowell, L. and Batnitzky, A. (2008). 'Emotional labour/body work: The caring labours of migrants in the UK's National Health Service.' Geoforum, 39(6), pp. 2030-2038.

Erel, U. (2010). 'Migrating cultural capital: Bourdieu in migration studies.' Sociology, 44(4), pp. 642-660.

Friedman, S. (2016). 'Habitus clivé and the emotional imprint of social mobility.' The Sociological Review, 64(1), pp. 129-147.

George, S. (2005). When Women Come First: Gender and Class in Transnational Migration. Berkeley: University of California Press.

Hochschild, A. R. (1983). The Managed Heart. Berkeley: The University of California Press. 
Huppatz, K. 2012. Gender Capital at Work: Intersections of Femininity, Masculinity, Class and Occupation. London: Palgrave Macmillan.

Jeffrey, R. (1988). Politics of Health in India. Berkeley: University of California Press.

Kittay, E. F., Jennings, B. and Wasunna, A. A. (2005). 'Dependency, difference and the global ethic of long term care.' Journal of Political Philosophy, 13(4), pp. 443-469.

Kodoth, P. and Varghese, V. J. (2012). 'Protecting women or endangering the emigration process. Gender and India's Migration Policy.' Economic and Political Weekly, 47(43), pp. 56-66.

Kofman, E. (2000). 'The invisibility of skilled female migrants and gender relations in studies of skilled migration in Europe.' International Journal of Population Geography, 6(1), pp. 45-59.

Kofman, E. and Raghuram, P. (2010). 'The implications of migration for gender and care regimes in the South.' In: Hugo, K. and Piper, N. (eds.), South-South Migration, pp. 46-83. Basingstoke: Palgrave Macmillan.

Kofman, E. and Raghuram, P. (2015). Gendered Migrations and Global Social Reproduction. Basingstoke: Palgrave Macmillan.

Laberge, S. (1995). 'Toward an integration of gender into Bourdieu's concept of cultural capital.' Sociology of Sport Journal, 12, pp. 132-132.

Marangozov, R., Williams, M. and Buchan, J. (2016). 'The labour market for nurses in the UK and its relationship to the demand for, and supply of, international nurses in the NHS.' Final Report. Institute for Employment Studies. Brighton. July.

Marginson, S. (2008). 'Global field and global imagining: Bourdieu and worldwide higher education.' British Journal of Sociology of Education, 29(3), pp. 303-315.

McCall, L. (1992). 'Does gender fit? Bourdieu, feminism, and conceptions of social order.' Theory and Society, 21(6), pp. 837-867.

McDowell, L. (2008). 'Thinking through work: Complex inequalities, constructions of difference and transnational migrants.' Progress in Human Geography, 32(4), pp. 491-507.

Naidoo, R. (2004). 'Fields and institutional strategy: Bourdieu on the relationship between higher education, inequality and society.' British Journal of Sociology of Education, 25(4), pp. 457-471.

Nair, S. and M. Percot (2007) 'Transcending boundaries: Indian nurses in internal and international migration', Centre for Women's Development Studies, New Delhi, occasional paper series. Available at: www.cwds.ac.in/occasionalpapers.htm

Oliver, C. and O'Reilly, K. (2010). 'A Bourdieusian analysis of class and migration habitus and the individualizing process.' Sociology, 44(1), pp. 49-66.

Osella, F. and Osella, C. (2000). 'Migration, money and masculinity in Kerala.' Journal of the Royal Anthropological Institute, 6(1), pp. 117-133.

Quisumbing, A. R. (2006). 'Investments, bequests, and public policy: Intergenerational transfers and the escape from poverty.' In: Addison, T., Hulme, D. and Kanbur, R. (eds.), Poverty Dynamics: Interdisciplinary Perspectives, pp. 267-288. Oxford: Oxford University Press for CPRC.

Ribeiro, J. S. (2008). 'Migration and occupational integration: Foreign health professionals in Portugal.' In: Saks, M. and Kuhlmann, E. (eds.), Rethinking Professional Governance: International Directions in Health Care. Bristol: The Policy Press.

Sassen, S. (2011). Cities in a World Economy. London: SAGE Publications.

Savage, M., Devine, F., Cunningham, N., Taylor, M., Li, Y., Hjellbrekke, J., Le Roux, B., Friedman, S. and Miles, A. (2013). 'A new model of social class? Findings from the BBC's Great British Class Survey experiment.' Sociology, 47(2), pp. 219-250. 


\section{Migrating gendered capital}

Shields, M. A. and Wheatley Price, S. (2002). 'The determinants of racial harassment at the workplace: Evidence from the British nursing profession.' British Journal of Industrial Relations, 40(1), pp. 1-21.

Skeggs, B. (1991). 'Challenging masculinity and using sexuality.' British Journal of Sociology of Education, 12(2), pp. 127-139.

Smith, P. and Mackintosh, M. (2007). 'Profession, market and class: Nurse migration and the remaking of division and disadvantage.' Journal of Clinical Nursing, 16(12), pp. 2213-2220.

Standing, G. (2011). The Precariat: The New Dangerous Class. Bloomsbury Publishing: London and New York.

Root, J., Gates-Gasse, E., Shields, J. and Bauder, H. (2014). Discounting Immigrant Families: Neoliberalism and the Framing of Canadian Immigration Policy Change. RCIS Working Paper, No. 2014/7. Ryerson centre for immigration and settlement, Generation: The Development of Bourdieu's Intellectual Heritage in Contemporary UK Sociology, p. 88. Toronto: Ryerson University.

Thatcher, J. and Halvorsrud, K. (2016). 'Migrating habitus.' In: Thatcher, J., Ingram, N., Burke, C. and Abrahams, J. (eds.), Bourdieu: The Next Generation: The Development of Bourdieu's Intellectual Heritage in Contemporary UK Sociology, pp. 88-106. Abingdon and New York: Routledge.

United Nations (2016). 'Department of Economic and Social Affairs, Population Division. International Migration Report 2015: Highlights (ST/ESA/SER.A/375). New York, United Nations.

Waldinger, R. (1993). 'The ethnic enclave debate revisited.' International Journal of Urban and Regional Research, 17(3), pp. 444-452.

Walton-Roberts, M. (2012). 'Contextualizing the global nursing care chain: International migration and the status of nursing in Kerala, India.' Global Networks, 12(2), pp. 175-194.

Welter, F, (2011). 'Contextualizing entrepreneurship - conceptual challenges and ways forward.' Entrepreneurship Theory and Practice, 35(1), pp. 165-184.

Yuval-Davis, N. (2006). 'Intersectionality and feminist politics.' European Journal of Women's Studies, 13(3), pp. 193-209.

Zachariah K. C. and Irudayarajan, S. (2012). Kerala's Gulf Connection, 1998-2011: Economic and Social Impact of Migration. Hyderabad: Orient Blackswan.

Zhou, M. (2004). 'Revisiting ethnic entrepreneurship: Convergencies, controversies, and conceptual advancements.' International Migration Review, 38(3), pp. 1040-1074. 


\title{
7 Gendered violence and victimisation
}

\author{
Symbolic violence and complicity
}

\section{Introduction}

Despite the impressive pointers of women's progress and embodied female capital in Kerala, violence against women (VAW) is rising both in the state and across India. ${ }^{1}$ This rise includes sexual violence (including rape), domestic and intimate partner violence, oppressive practices of dowry, and organised crime (including prostitution). This chapter will examine how Bourdieu's concept of symbolic violence is enacted at different levels: at the micro-level in women's everyday lived experiences in the private sphere, often through processes of complicity and consent, and more broadly in terms of how macro-politics and institutional complicity reify physical and symbolic violence against women and girls, leading to gendered justice. For this, discourses from feminist criminology on crime, violence and victimisation will be examined. The chapter then analyses crime and violence in Kerala before focusing on this study's primary research findings regarding individual perceptions on VAW in Kerala. The chapter will show how the matrix of patriarchy, power and social relations within the Kerala context tie in with Bourdieu's concepts of misrecognition and symbolic violence. For this the study will draw on social perceptions of specific forms of VAW to highlight how men's and women's attitudes to patriarchal structures in both the private and public sector collude with, and are embedded in, gendered practices and policies within the wider political, legal and judicial institutions and systems.

\section{Feminist discourses on violence against women: symbolic violence and misrecognition}

Discussions on violence against women and girls within development debates have made little attempt to incorporate perspectives from feminist criminology, particularly in relation to the social construction of crime, violence and victimisation, as well as subsequent inequalities in the legal and criminal justice system. Feminist perspectives on gender and violence have been useful in understanding societal viewpoints on how gender matters in violence (Gelsthorp and Morris, 1990; Walklate, 2004; Heidensohn, 1996; 2006; Garcia and McManimon, 2011). For example, crimes relating to sexual violence are most often interpreted as 
"socially constructed" and consequently instrumental in ideologically reinforcing power relations, thus "demonizing" and "labelling" the victims of such crimes.

Several feminist criminologist perspectives have contested biological explanations of crime set forth by studies in the early part of the twentieth century, as that of the Italian psychiatrist Cesare Lombroso (1911). Such notions are framed alongside Sigmund Freud's claims, based on psychiatric constructs, about female criminality being rare. In particular, liberal feminists have linked sociological factors such as emancipation to women's criminality (see Adler, 1975). Perspectives based on socialist feminism, influenced by Marxism and radical feminism, view crime as a result of patriarchal capitalism, with the confluence of gender, race and class relations; as for Mies (1986), capitalistic relations include violence against women and extracting women's labour through structural or direct means. Criticizing the reductionist assertions of liberal feminism, feminist perspectives have drawn on radical feminist notions of male power and privilege, which are exercised through patriarchal relations in both private and public spheres, and the root of all social relations, inequality and crime. Such social control regulates women and their bodies through their sexuality and reproduction. In a VAW context, social learning theories suggest that - through social norms, socialisation, upbringing, associations and observations - a perpetrator's performance of VAW can get reinforced, particularly if such perpetrators are seen as role models (Bandura and Walters, 1963). For this reason, boys from violent backgrounds are more likely to commit acts of violence against their partners (Bandura and Walters, 1963). Connell's (1987) theory of the relationship between gender and violence is situated in a wider social context of social structures, and it explores diverse gendered behaviours among men and women. For example, the family is recognised as one site of danger and violence where, through socialisation, young people are socialised into a patriarchal culture that normalises and often encourages male power and aggression within heterosexual relationships (Fineran and Bennett, 1999). Furthermore, men's heterosexual violence being viewed as customary (Connell, 1990; Messerschmidt, 2012) normalises women's endurance of it (Stanko, 1985) and such domination sets the context for complying with violence in various settings, including the family.

The ways sexual violence by men towards women is normalised are evinced through feminist research on "fear of crime" (Stanko, 1985; 1990) where, on both an individual and institutional basis, men's dominance creates the context for sexual violence. Normalisations of gendered fear, practices and norms lead to complicity, for example, of the victim or other agents. This then leads to different forms of control and violence in women's everyday lives, pervading both the public and private sphere. In addition to how victimisation is gendered, offending is also a gendered phenomenon. For example, in established capitalist and/or Western contexts, female offending mostly relates to less serious crimes whereas men predominate in serious crimes, such as murder, but are also usually victims of such crimes (Walklate, 1995). Yet society's reactions to female crime is more punitive, for example through increased reporting and media coverage, or such women being demonized as harlots, pathologized as victims of their own biology or seen as mentally unstable (ibid). 
The concept of symbolic domination of gender and that of symbolic violence in particular were explored in Bourdieu's (2001) later work, Masculine Domination. For Bourdieu and Passeron (1990, p. 4), misrecognition is a 'process whereby power relations are perceived not for what they objectively are but in a form which renders them legitimate in the eyes of the beholder'. Thus, symbolic violence constitutes and reproduces domination in the immediate interactions between people and structure, and it 'is exerted only with the collaboration of those who undergo it because they help to construct it as such' (Bourdieu, 2000, p. 171). Indeed,

Symbolic violence is the coercion which is set up only through the consent that the dominated cannot fail to give to the dominator (and therefore to the domination) when their understanding of the situation and relation can only use instruments of knowledge that they have in common with the dominator, which, being merely the incorporated form of the structure of the relation of domination, make this relation appear as natural.

(Bourdieu, 2000, p. 170)

Bourdieu's theory of symbolic violence helps in understanding both the "visible" and the "invisible" nature of violence, explaining why these persist and are reified in the public sphere in terms of both explicit interpersonal violence, such as domestic and/or sexual abuse, and implicit symbolic violence as a mode of domination. Forms of symbolic violence are embedded in the "normal" routines of everyday lives and they shape social experiences and subjectivities in a myriad of ways (Morgan and Bjorkert, 2006). Other overt forms of violence against women stem from the notion of son preference based on historical, patriarchal and cultural practices, wherein women themselves are complicit in its everyday practice (see Purewal, 2010; Alston, 2014). For example, dowry practices, female foeticide and infanticide through sex-selective abortions are increasing and these may affect India's sex ratio. What is clear is that gender provides a useful lens in examining how crime is viewed and constructed, both through social practices, representation and societal control. The chapter next attempts an overview of specific forms of crime and violence in the context of Kerala.

\section{Crime and violence in Kerala: a gendered lens}

In India, statistics on violence and crime based on reports from the National Crime Records Bureau (NCRB) are widely available. Measurements of violence are available for both the incidence (number of times in a given time period) and prevalence (occurrence during a person's lifetime), and are based on statistics or reports on crime rates, which disaggregate victims by gender and type of crime. Recent statistics show that Kerala had the highest rate of criminality ${ }^{2}$ based on Indian Penal Code offences, with 455.8 cases for every 100,000 persons, followed by the states of Madhya Pradesh and Tamilnadu (The Hindu, 2013a). There is, of course, a caveat regarding the data and reporting, as the reporting of crimes may be higher in Kerala because of its higher levels of social awareness, agentic 
factors such as literacy, and history of collective resistance and protests. However, such data may not fully reflect the true extent of crimes, as many incidences may go unreported or unregistered.

A gendered view of crime and violence is useful in terms of looking at patterns of crime committed by men and women, the differences in their causes and outcomes, and how gender is constitutive in victimisation. For example, in Kerala the crime rate trends over recent years show that its total crime rate in the early nineties was less than half the national average. This rate passed the national average in 1997, perhaps because of the active role played by State Women's Commission in addressing women's concerns (see Kumari, 2009). Previous studies have reported the gendered nature of offending rates (e.g. Heidensohn, 1996; Walklate, 2004), with women primarily committing "feminine" offences (e.g. petty theft, prostitution etc), and having significantly lower violent crime rates than males. Kerala is no different, with men involved in serious and organised crimes such as gang or quotation-related killings and serious assaults, including hate crimes (e.g. severing a college lecturer's limb). Financial crimes are on the rise in Kerala; in these, the perpetrators and the victims are mostly men. ${ }^{3}$ As seen in Chapter 3, out of the total reported cases of crime against women for the year 2014 'cruelty by husband/relatives' still constitutes a major component in crime against women. Further, in Kerala the Rate of Total Cognizable Crimes (incidence of crime per one 100,000 female population) is much higher than the national level (NCRB, 2015).

The institutionalisation and normalisation of dowry practices (see Kodoth, 2010) often confine women's interest and the feminine identity through arranging alliances, with implications for gender relations. Such social practices are also manifested in the continuation, or even permanence, of violence in women's lives, where symbolic violence accompanies physical violence. This is indeed a signifier of negative gender capital, as we see an erosion of female and feminine capital within the increasing patriarchal practices in Kerala, and a reversal of practices that value girls and women, for example, through matriliny and claims of gender equality. Data on sexual violence in India shows a sharp increase in, for example, rates of rape against women (NCRB, 2015). Further, age is an important factor in rape cases, as rape victims are disproportionately younger, ${ }^{4}$ with over 85 per cent of such victims younger than 30 (NCRB, 2015). This relates to Shreekumar's (2007) portrayal of a "dystopic" vision of Kerala, with an increasing prevalence of sexual crimes against women juxtaposed alongside narratives of "sex rackets" involving individual (younger) women. Some of the cases of sexual exploitation in the state are highlighted here to show how symbolic violence is enacted through "voluntary servitude" and processes of complicity.

The Kozhikode Ice-cream Parlour case is one of Kerala's most controversial cases of sexual exploitation because of the alleged involvement of P. K. Kunjhalikutty, a former minister in the UDF government and the leader of the Indian Union Muslim League (IUML), or Muslim League, though his name was dropped from the list of the accused in 2011. The case shows how young girls and women were subject to sexual exploitation by consuming "spiked" ice-cream (see Kavil, 
2012). This case was delayed many times through victims retracting their statements, but much frenzy was created when, on 2 December 2004, Regina, one the victims, in an unusual encounter with the media, revealed that she had handed a letter to the court absolving Mr Kunjhalikutty because of pressure from various sides. She also stated that she had been forced by her husband to give a statement, even though this was against the wishes of Anweshi - a women's NGO to whom the victims in this case had turned (The Hindu, 2013b). Following these events and widespread agitation, the minister stepped down in late 2004, but he subsequently served as a minister again (with the UDF government) until 2016.

The infamous case of Sooryanelli ${ }^{5}$ was a long and protracted struggle for meaningful justice against sexual violence, the saga continuing from 1996 to 2013. The case drew much attention both in the media and through women's protests because of the alleged involvement of a prominent congress member of parliament, who was dropped from the list of the accused. ${ }^{6}$ The case was held in a Special Court, with 39 on the accused list; 35 were initially sentenced, of whom nine (including one woman) received rigorous imprisonment because of the guilty verdicts on rape, mass rape, abduction, illegal detention and the sale of a minor girl for sexual abuse. ${ }^{7}$ Women were also the key link in the scandal, showing how women are also complicit in sexual crimes, with implications for gender in both offending and victimisation (similar to most cases of such a nature). As Bourdieu (2000, p. 171) states, the case of complicity is "not granted by a conscious deliberate act; it is the effect of a power, which is durably inscribed in the bodies of the dominated, in the form of schemes of perception and dispositions'.

Other recent cases of violence against young women have also drawn much attention. The April 2016 murder of Jisha, a Dalit 29-year-old law student, in Ernakulam provoked protests across the state against brutal crimes against girls and women from marginalised groups. Jisha came from poor living conditions as her mother was a casual worker. She was also estranged from her daughter's father, so media reports often referred to the Jisha as having a "dysfunctional" family. Support for the victim gathered momentum through the social media hashtag (\#JusticeForJisha), with the active involvement of politicians, soon after which the Special Investigation Team charged a migrant worker from Assam with her rape and murder under the Dalit Atrocities Prevention Act. The case of Soumya, a 23-year-old sales representative who was raped and killed on a train near Thrissur, also received much media attention on issues regarding the safety of women as they travel on public transport and showing the abuse by a disabled beggar, Govindachamy, in a public space. Given the public outcry against the heinous crime, a speedy handling of the case awarded the offender a death sentence. Yet in September 2016, the Supreme Court reduced his death penalty to life imprisonment on the grounds of lack of motive to kill (Manorama online, 2016, online). These cases show that through manifestations of institutional power and practices, symbolic violence pervades gendered injustice, and women and girls are socialized into a culture of heteronormative views on sexuality, with fear of sexual violence embedded in everyday lives. As feminist criminologists note, the constant fear of (sexual) assaults on women, against which women must constantly 
protect themselves, is suggestive of "normalising" men's control and power over women's sexuality (see Stanko, 1985; 1990), and this is no different in Kerala. In the context of violence against girls and women, social perceptions towards such crimes provide a useful lens on symbolic violence, gendered justice and socialisation. The next section specifically examines public perceptions towards violence against women (VAW), domestic violence and sexual violence.

\section{Data and findings}

The study distributed 75 questionnaires to 40 households in two regions - Aluva in the district of Ernakulam, and in Thiruvananthapuram - during August 2016. These questionnaires were distributed through housing association groups that acted as gatekeepers to the respondents. In addition, the two association groups facilitated interviews with 28 women from their Ladies Group (a group of women who take up activities for women only). Women with young girls (8-21) were purposively included in the sample to ensure the study investigated issues concerning fear of violence against women and girls, got broad input regarding the social construction of sexual violence etc. The Housing Association Committee Group acting as gatekeepers also facilitated the building of rapport, trust and co-operation between the researcher and participants. Mothers - both housewives and working women - participated in a focus group discussion (FGD) and shared their views on the troubling level of violence against women and girls in the state. The sample was a mix of respondents (both male and female) from various residential locations who self-identified themselves as middle-income and lower-middle-income classes, which reflected different perceptions, outlooks and material circumstances. For instance, one housing association group comprised houses with both self-owned and rented properties, with occupants from diverse occupations and employment areas such as working in banks, government offices, schools and universities as well as those in self-employment, owners of small businesses and taxi drivers. The other association group was based in a city-centre flat and comprised middle-class occupants, both self-owning and renting. Such a mix allowed diverse perceptions on gendered violence and also helped the work to consider factors such as age, education, social class, gender and occupation. The participants were keen to discuss the topics, although care was taken to focus solely on perceptions and attitudes, or of others' experiences of violence (e.g. crimes reported in public media), rather than relating individual experiences. This focus allowed them to speak more freely and voice their opinions objectively, which gained trust in the research process. Generally, there were high levels of anxiety about violence towards women among most respondents, irrespective of their gender, education and social location. These discussions lasted for two hours and were written in Malayalam then translated. Participants were consistently allowed to raise and discuss subjects important to them in response to questions such as "Why do you think these happen? Who should one talk to? How did they respond? How did you feel about that? Are you worried about anything?", 
which generated rich narrative data that complemented the questionnaire on perceptions of gendered violence that men and women completed.

\section{Perceptions of domestic violence against women: complicity, misrecognition and micro-politics within households}

Table 7.1 summarises statement responses from men and women regarding perceptions of domestic violence against women. These observations were not quantified or ranked, as the research objective was mainly to decipher the range of perceptions and attitudes. In all, both men and women acknowledged that domestic violence may be overt but also may be covert forms of control, where both partners as well as extended families may be complicit. Latha (46, schoolteacher from Aluva), said:

My husband's sister was subject to emotional abuse and control by her inlaws, through bullying, threats and harassment. This was mostly because of constant demands for money, as dowry, for various purposes, and she was not allowed to see her family unless these payments were made. My husband was helpless and often succumbed to these threats as he was concerned about his sister's future.

\section{Q}

Table 7.1 Perceptions on Causes of Domestic Violence against Women

Perceptions on Key Causes

\section{Socialisation}

Male control is necessary and acceptable.

Women are subordinate to men within families.

\section{Education}

Education improves awareness on gender equality.

Education addresses notions of violent behaviour.

\section{Economic}

Women's access to economic resources improves bargaining position.

Domestic violence does not take place in higher-income-earning households.

\section{Alcohol and Substance Use}

Addiction is cause and consequence of violent behaviour.

\section{Lack of protection for women}

State policies, laws and families do not protect women.

\section{Media Representation}

Images and representations of violent behaviour towards women in mainstream media normalise violence.

\section{Other}

Psychological factors.

Social learning.

Religious and cultural factors. 
Thus, families, including men, can be complicit when close kin are trapped in abusive relationships and are under domination, but they often do little to challenge these situations for fear of divorce, shame and abandonment. As Krais (1993, p. 172) states, while an individual may be able to 'decode the relevant signals and to understand their veiled social meaning' this is 'without recognising them consciously as what they are - namely as words, gestures, movements and intonations of domination'. Symbolic violence is perpetually embedded in social norms and attitudes towards cultural practices such as dowry, and it is often accepted as everyday practice.

Control over resources often emerged as causing friction within households, as men tended to think it best for one person, the male head, to make decisions about finance, even in cases where women owned key resources such as property or were income earners. Some women from matrilineal Nair households in Thiruvananthapuram owned property such as a house, or even land that generated income for the households, yet men remained dominant in key economic decisions. Both men and women felt men to be better placed in making such financial decisions and could better allocate resources for the household and maximize investments based on their financial wisdom compared with women, who would merely rely on investing in chit funds and in purchasing jewellery. Consequently, women did not feel confident in making, or indeed taking part in, key financial decisions.

Evidence from other South Asian contexts shows that ownership of property plays a role in inter-spousal violence (ICRW, 2006). In Kerala, education did not affect women's experience of violence (Panda, 2004); on the contrary, women with a graduate degree reported a slightly higher level of violence (SAKHI, 2004). Research in Kerala has shown how socio-economic factors are significant in violence against women, highlighting the need for greater economic control over resources, including property ownership (Panda, 2004; Agarwal and Panda, 2007). The negative correlation between ownership of property and the reporting of physical and psychological domestic violence is a critical observation. More research is needed into how far ownership of property could translate into such outcomes, including nuances of issues of differences between ownership, access and control of such resources. Of course, factors other than socio-economic ones, such as class, are also significant in perpetuating violence within the family, particularly where female ownership of property is common among matrilineal households.

Evidence of the increasing prevalence of abuse within the private sphere and households has indeed brought into question the safety of homes - now sites of oppression that operate through gendered ideologies of power. Also known as intimate partner violence (see Garcia and McManimon, 2011), these abuse cases take place within intimate relationships. Also, reported cases of violence against women across the state have increased (Kumari, 2009), with 40 per cent of women in Kerala having experienced some type of domestic violence during their lifetime (SAKHI, 2004; Panda, 2004), whether this be physical or psychological. Mukhopadhyay (2007) notes that using mental health indicators within the broader 
framework of a socio-economic household survey may help understand the extent to which various forms of violence and abuse have been internalized. Despite women's instrumental "roles" in social development, certain deep-rooted social constructs (embedded in patriarchal ideologies of gender) and other social divisions are institutionalised and often essentialised. They operate through gendered justice or violence, as evinced in SAKHI's (2004) report:

In the context of Kerala, though women are highly literate when compared to other states, their decision making, autonomy, public participation, work participation and mobility are still severely restricted. In such a situation, it is not fair to assume that women in Kerala will be vocal and come out in the open about the violence they face in the public or private spheres. The stigma of violence against women within homes, especially from husbands, the unwillingness to relive the experiences, no guarantee for benefit, the possibility of re-victimisation and the shame and blame prevent them from disclosing the information to outsiders and particularly the health system that they do not see as a potential source of help.

In the study sample, both men and women agreed that alcohol dependency was increasingly common in many households, leading to verbal abuse and, in many cases, physical violence (see Table 7.1). But they also pointed out that representations of abusive and violent behaviour towards women, irrespective of their roles (wife, sister, colleague), particularly through abusive and demeaning language and by slapping as is shown in various media - films, TV serials and other programmes watched by the popular masses - conveyed society's complicity in tolerating abuse towards women of all ages. Notably, education did not play an important role in attitudes towards domestic violence against women, but age was significant. Men below 35 felt that women had equal status in the household and took key decisions regarding the household, though they did infer to basing these decisions within "normalising" gender norms such as division of labour, respect for in-laws and economic contribution to the household. Men and women above the age of 40 felt that the family structure determined gender hierarchy. In these households, women were seen as grihalakshmi, or goddess of the house, with the key role of grihasta, or homemaker, often in subjugation to their men, despite women's progressive role in the public sphere.

Some women referred to the experiences of other women they knew, noting how psychological violence was common but less visible and less resisted. Sajitha (45-year-old, a teacher) said: 'Restraints on physical mobility were one of the main features of such practices my colleague complained of-where she goes, and who she talks to.' Such circumstances often make women depressed or stressed and too afraid to talk about their situation as it may hurt their children or their parents. As Morgan and Bjorkert (2006) note, women would rather suffer with physical than psychological abuse as there are no overt signs of such abuse; consequently, though, the fact that it is not immediately identifiable, which many want, means very little is done about it. Most respondents felt that gender-based socialisation 
within families, religious teachings and media representations reinforced everyday violence, both overt and covert, against women. Social learning theory is therefore key to changing gendered behaviour and responses to this violence.

Regarding responding to violence, sociological perspectives on deconstructing domestic violence often involve 'blaming the victim, understanding the victim and structuring the victim' (Walklate, 2004, p. 129). Studies on victimology show that the "victim blaming" ideology concerns an individualized approach to responsibility in violent activity (see Karmen, 2010; Ryan, 1976) where the victim has been deemed to have facilitated, precipitated or provoked the crime. However, in such individualized approaches structural factors such as gender, caste and class, which may reinforce the prevalence of such crimes, are ignored (Garcia and McManimon, 2011). Attempts to understand victims' actions (or inaction) ask questions such as "Why doesn't she leave?" (e.g. Straus, 1979; Gelles, 1983), with common answers being low economic status and stress relating to "family violence". Inversely, asking "Why does she stay?" points to gendered power relationships within patriarchal practices, which leave women with unequal status in social relations and little power and control, so the family/home engenders a risky site for women. Nisha (26-year-old, an IT worker) shared her friend's harrowing experience in reporting domestic abuse after seven years of marriage.

She was traumatized with questions about evidence of abuse, delayed court hearings and constant harassment by her husband's family, who opposed her efforts in taking the case to court. Her own strict conservative Christian family did not support her through the court case, despite the protection provided by legislations and policies.

The Domestic Violence Act was the first significant attempt in India to recognise domestic abuse as a punishable offence; in addition to legal recourse, its provisions extend to those in live-in relationships and to providing emergency relief for victims. ${ }^{8}$ Under this act, the law considers physical, sexual, emotional, verbal, psychological and economic abuse or threats as violence. ${ }^{9}$ While power relations between men and women must be deconstructed to understand the nature of violence and its effect on victims, men are also victims of violence, including domestic violence, as there is evidence of abuse against men (see Jin et al., 2014). However, this act does not cover men who are victims of domestic violence, which is a major lapse. The fact that men are not seen as victims of domestic abuse also exposes gendered constructs of violence on an essentialist basis, reified through such legal responses. Moreover, rape within marriage is also not covered under the present law, again illustrating the limits of legal responses to regulating the private-public demarcation of social and gendered rights, as Mackinnon (1989) discusses. The next section will explore women's attitudes towards sexual violence against women, and responses of both the police and the legal and justice systems to this, which brings out the themes of complicity and silencing within the public sphere. 


\section{Attitudes towards sexual violence against women: complicity, consent and institutional silencing}

As stated above, discourses on sexual violence must address the intersectionality of gender, class and sexuality - where the organised networking of sexual violence against women is on the rise. To understand women's personal fears, insecurities and (indirect) experiences, the study explored their perceptions on sexual violence, such as rape and sexual harassment in public spaces or at work, by discussing these topics only with women and girls in the sample. Men were not included in these discussions also because the Ladies Group felt that women would be more comfortable talking about this topic in a "women only" group. The discussions therefore took place during a routine meeting of theirs, using a focus group discussion (FGD) involving 18 women. The responses are provided in Table 7.2.

Women, particularly both working and non-working mothers, were keen to talk about the rising levels of violence against women and girls, including media

Table 7.2 Women's Perceptions on Causes of Sexual Violence against Women and Girls

Perceptions on Key Causes $\quad$ Women (\%)

1. Socialisation

Macho attitudes lead to sexual subordination to men. 72

Feministic views increase sexual violence.

\section{Education}

Education addresses notions of sexual impropriety.

Education empowers women and girls to address sexual violence.

\section{Economic}

Lack of economic resources lead to sexual exploitation.

4. Alcohol and Substance Use

Addiction among men leads to sexual violence.

5. Lack of Institutional Support for Women

State policies, laws and families do not protect women.

\section{Media Representation}

Everyday Images Representations of bodies and the objectification of girls and women sexualize gendered bodies.

Tolerance of sexual approaches towards women in mainstream media normalise violence.

7. Being alone in public places increases susceptibility to sexual violence

\section{Other}

Psychological factors. 
coverage of these issues which highlighted their anxiety about and fear of such sexual violence, framed as a "normal' fear. As one young woman (21, student) stated:

In Kerala, one only requires to skim through media reports, visual, text and electronic, to see the number of distressing cases of sexual violence in the state, but despite all media attention there is very little conviction and justice. In many ways this has to do with the sexualization of women's bodies through popular discourses.

The normalisation of women's bodies and sexualisation is increasing both through media images and popular discourses. This observation is in line with Devika (2009), who writes that sexuality is obscured in development discourses, particularly in terms of the sexualisation of female bodies. Development discourses that highlight women's subordination in physical and material terms, often neglect their sexual subordination.

Another woman (42, banker) said,

The gendered constructions of the body and behaviour of both men and women, through media representations and cultural practices, normalize male aggression and dominance while constantly framing women as submissive and passive.

Stanko (1985, p. 73) argues that 'women learn, often at a very early age, that their sexuality is not their own and that maleness can at any point intrude into it'. Girls are expected to endure aggression by men because it is part of men. Similarly, feminist scholarship on compulsory heterosexuality and heteronormative discourses often links female sexuality with passivity, vulnerability and submissiveness but male sexuality with dominance, aggression and desire (Connell, 1990), conveying women as sexually subordinate to men, which is often framed as natural and unproblematic. Consequently, such violence is deemed normal when viewed through dominant discourses of compulsory heterosexuality (Hlavka, 2014).

Mothers of young girls share deep anxiety about their girls in the state. A mother of a college student (Shiny, 43, housewife) said that crimes against young girls involve "grooming" and "luring" them. She pointed out that this occurs within societal happenings such as transformations of popular media images, mass consumerism, the sexualisation of bodies, and gendered expectations of individuals and social groups. A common observation from many mothers was how macho attitudes practised at home and reinforced through media representations lead to women's sexual subordination to men. For example, terms such as "appropriate dressing", "modesty", "he's a boy" or "you're a girl' were common, as was the advice for women not to be "seen" in "public places" "after dark", suggesting gendered notions concerning the body, morality, safety and public places (even temporal aspects regarding the diurnal and nocturnal). Such observations also 
suggest that feminist notions of equality and liberation are inappropriate within homes - a private sphere where male domination is a cultural norm.

Women drew examples of several cases of sexual violence against women that involved luring young girls into something but where women played a catalytic role (both consensually and complicity) in such violence. For example, in cases such as Sooryanelli, Ice-cream and Kiliroor, women, including close relatives, were instrumental in subjecting these minors to sexual exploitation. In another case, Sobha John, with several accomplices, played an active role in blackmail and extortion. The recent 2016 Solar scandal ${ }^{10}$ also brought issues of gender, sexuality and crime to the fore. From this, radical feminists cautioned against emphasising the victimisation of women, as with this women are seen to be passive (Walklate, 1995) and engaged in the gendered representation of "deviance". During the FGD, women also observed that education neither addresses notions of sexual impropriety nor empowers women and girls to fight off certain forms of sexual violence (e.g. harassment in public places) simply because these are "normalised practices" of heterosexual behaviour.

Economic factors, poverty and aspirations were very much noted among participants. Shiny (43, housewife) said: 'Young girls are motivated by rising consumerism and expectations of a good life through quick money and they are often lured into exploitation or romance.' But as Hudson (1990) shows, deviant women who resist the hegemonic power of the family, sexuality and the state are pathologized in traditional paradigms of violence and are seen as exhibiting "risk-seeking behavior", while young male delinquents are compared with romantic rebels. For Devika (2009, p. 35), victims are associated with 'sexualized labouring bodies, linked to the working class and depicted as shameless gold-diggers who have sold their honour for sexual favours'. In other contexts, Buzawa and Buzawa (2003) show that a lack of victim co-operation, for example where the victim is reluctant to testify, is another reason for the police and prosecutors not to explore the reasons for lack of cooperation. Issues concerning lack of evidence and retracted statements of witnesses (and the victims themselves) are common in most trials of serious crime, though cases of sexual violence are all the more complicated because of their sensitive nature. In cases of violence against women, issues related to lack of evidence are primary reasons for such attitudes; others include a lack of witnesses and deficient police training - for example, in identifying the primary aggressor or in working with someone who is experiencing fear and/or trauma (see Garcia and McManimon, 2011).

A working mother, Molly (50, employee in a state-sector bank), shared her concerns about how young girls' sexuality is tangled within circuits of power, politics and social attitudes as well as the lack of institutional support available to protect victims - both from political parties and influential groups in society. Kavil (2012) observed various commonalities in high-profile sexual scandals: the young age of victims; sexual grooming; the direct involvement of an organised network of parties; prolonged justice; political intervention and corruption to pervert the course of justice; and prolonged social debates about the morality of the victim and (her) family. As seen in the Ice-cream parlour case, the Kerala High Court dismissed 
the petition that sought Mr Kunjhalikutty's prosecution. When the Supreme Court dismissed the case, it cited lack of evidence ${ }^{11}$ and interventions led to the exclusion of the IUML leader from the list of the accused. Data on the social attitudes towards victims is often gendered and racialised (Garcia and Schweikert, 2010). Also, where prior knowledge of the offender or a relationship between the victim and offender already exists, reporting is also doubtful (for more, see Karmen, 2010; Garcia and MacManimon, 2011).

Sexual violence is demonstrably a powerful form of social control of women, as feminist analysts have argued (Brownmiller, 1975); rather than merely viewing this mechanism as an act of sex, though, the sexual dimension must instead be examined in a societal context. Social hierarchies are maintained in public and private spheres (Mackinnon, 1989). Regarding the former, police - as gatekeepers of the criminal justice system - play an important role in responding to, assisting the victims of, and arresting and charge-sheeting the accused in crimes. However, the "classic police response" to cases of violence against women, particularly domestic violence, often involves enforcing social constructs (e.g gender subordination and male power) and it is actually a "do-nothing response"; often, such cases are deemed private matters (Melton, 1999; Buzawa and Buzawa, 2003) that are often framed within the limits of domesticity. Thus, social learning was also seen an important cause for violence.

Rape is commonly deemed the worst form of gender conflict, but it is subject to cultural and ideological constructs of gender processes. ${ }^{12}$ In the Sooryanelli case, despite firm allegations by the victim that the prominent politician was among the many who raped and assaulted her at a public guest-house when she was a minor, many forms of institutional silencing worked against the victim. These included conflicting statements about his involvement, strong support from political aides at both state and national levels, and the refusal of the police authorities and the director of enforcement to register a case against him, which are all enactments of societal and institutional approval of such assaults. Thus, the ways rape is perceived both socially and legally often reflect how the legal and justice systems are created and maintained, particularly as these processes usually support groupmaintenance interests (Los, 1990). These processes therefore guide or "encourage" such perceptions and in doing so they protect the legitimacy of the dominant groups whose interests these systems serve (yet, in a cyclical process, the latter point is the very reason they influence these perceptions). The social constructs of victimhood are clearly at play here, where public discourses largely focus on blaming the victim - for example, in the Sooryanelli case senior politicians and judges, overtly and otherwise, questioned the social morality of the defendant ${ }^{13}$ and her family (e.g. indirectly through the media), reducing the case to one of child prostitution. The conflicting reports of the age of the victim attracted outbursts from women activists (see Indian Express, 2013) but fulfilled their purpose of questioning the morality and motivation of the victim.

Most women agreed that victims of sexual abuse are often labelled as wayward and ostracized, often citing Regina's example in the Ice-cream Parlour scandal. Research shows how the legal and medical systems' treatment of survivors of 
sexual assaults often leads to a further traumatic experience of a second rape or subjection to secondary victimisation, where they are blamed, doubted and revictimised (Campbell, and Raja, 1999). As Silvestri (2006) states, girls' vulnerability continues in the criminal justice system. The trauma of such victims is summarised in the words of the Vithura victim (a sexual exploitation case in Kerala, cited in Kavil, 2012): 'The maximum punishment in a sexual abuse case is 14 years of imprisonment and what I experienced in the past 15 years is worse than the imprisonment. I have lost all hopes of justice. Leave me alone.'

In November 2016, the vulnerability and victimisation of female victims of sexual violence caught media attention after a celebrity dubbing artist, Bhagya Lakshmi, shared on Facebook the story of gang rape victim's experience at the hands of the police and other authorities, thereby attracting much attention. Among the accused was a municipal councillor, and the victim alleged harassment from police officers who taunted her by asking 'which of the rapists gave her the most pleasure?' (Indian Express, 2016). At a press conference with the celebrity artist, the victim named the four accused but stated that, because of pressure from the investigating officer and her prolonged harassment (e.g. being constantly paraded in the police station), she was withdrawing her police complaint. Thus, macropolitics and "institutional silencing" take many forms, even when "following" formal procedures such as routine process, questioning victims about their prior sexual histories and behaviour, including their dress code, and even encouraging them to compromise with the accused and not to prosecute. In a form of restorative justice, the Sooryanelli victim was offered a job as an office assistant but was later charged with fraud in 2012, which she claims was the result of harassment. These attitudes and norms, which often masquerade as necessary or permeate routine procedures for legal and policing institutions, are akin to but arguably, generally, much stronger than "institutional sexism", ${ }^{14}$ where policies, procedures and attitudes reflect and reinforce discrimination and stereotyping but further victimise the subjects, as these cases show.

Connell's (1990) work illustrates how gender in society is viewed in both the private and the public spheres largely through the lens of hegemonic masculinity. As Mackinnon (1989, p. 161) states, 'Men's forms of dominance over women have been accomplished socially as well as economically, prior to the operation of law, without express state acts, often in intimate contexts, as everyday life.' The Jimmy Saville case in the UK exposed the massive scale of sexual violence against young girls and boys across many institutions, bringing various advances in how sex crimes are investigated, the treatment of victims and the introspection of cultural attitudes towards sexual violence. In Kerala, trials for rape and sexual violence have a low conviction rate due to a range of reasons, including the shortage of investigative officers, the inefficiency of officers involved, corruption, pressure from politicians and delayed trials (Kumari, 2009). All this in many ways reflects the operation of the Gramscian concept of hegemony through cultural and ideological means, which helps the dominant group in persuading, achieving, particularly through the media, and securing the spontaneous consent of subordinate groups (Strinati, 2004). 


\section{Conclusion}

This chapter explored how the matrix of patriarchy, power and social relations tie in with Bourdieu's concepts of misrecognition and symbolic violence in the Kerala context through examining the rising rates of violence against women and girls. One can conclude that the rhetoric on the Kerala woman as endowed with higher-than-average capabilities and accomplishments has not necessarily helped her at either an individual or a collective level. Much worse, rape, molestation and dowry-related crimes are the major contributors to crimes committed against women in Kerala. Mukhopadhyay's (2007) analysis on the 'enigma of women's status in Kerala' shows rising violence against women in Kerala society indicates their powerlessness and subordination. Studies have pointed out that literacy in particular has not guaranteed any protection from sexual violence (Panda, 2004; SAKHI, 2004; Mukhopadhyay, 2007). Rather, issues emerging from patriarchal structures that govern gender rules in the household and wider society - for example, the sexual relations, cultural practices and representations of gender in private and public spaces - are, to a large extent, embedded in practices and policies within the wider political, legal and judicial institutions and systems. Such perceptions are drawn from the naturalisation of one's cultural position whereby "misrecognition" is used to describe the ways social actors come to view such positions as normal and natural.

Overall, violence against women in Kerala is increasing, and the concept of symbolic violence has been useful to draw out the modes of domination at the meso-micro and at the macro levels, which reproduces gendered domination. At the meso level, those institutional and organisational cultures that tolerate the practices of male dominance and gender subordination, hostility towards women and norms regarding sexual relations must be addressed. Also, changes at the macrosocietal level through legislations and policies must correspond with changes at the micro levels through individuals and households. Making these changes would mean tackling forms of oppressive male control of social and economic decisionmaking, particularly male violence in the family. Evidently, sexual violence can be socially constructed and reinforced through gendered workings of the legal and justice systems, which are indeed institutional sexism but also much more. Such practices are also instrumental in ideologically reinforcing sexual and power relations, where victims of such crimes (usually young and female) are demonized and labelled as deviant, whereby the representation of "deviance" is gendered. Victims are frequently not only subjected to public trials by legal systems but also often by the media, and it is in both of these that such institutional and public perceptions of crime are framed, albeit within the parameters of gender, domesticity and sexuality (particularly heterosexuality).

Often, violence is linked to masculinity, and as a gendered construction. Simultaneously, power relations between men and women must be deconstructed to understand the nature of violence and its effect on victims, who can be both men and women: we must not forget that men are also victims of sexual crimes, including domestic violence. Nor should it be overlooked that women are sometimes key perpetrators of crime, including sexual crimes against other women, and are 
more harshly treated and punished by both institutional and societal responses. The legal, judicial and policing systems further lack gender-sensitivized practices in terms of collecting evidence and providing support. The low prosecution and conviction rates for sexual crimes, which are largely the result of power relations and political pressure, commonly lead to the withdrawal of complaints and victims' statements. This shows that, despite women's instrumental roles in Kerala's social development, deep-rooted social constructs are institutionalised and often essentialised, and they operate through the workings of gendered justice. All these conditions clearly point to the erosion of female and feminine capital in the public and private spheres as well as the devaluation of the Kerala woman and girl. Alas, an increasing number of sexual violence cases are enmeshed within the politics of institutional silencing, male domination and patriarchal structures.

The Delhi rape episode was indeed a watershed moment that has helped focus the lens through which rape is seen in India, as it led to nationwide protests and the Verma Report, yet these responses have silenced the history of sexual violence experienced by lower-caste and lower-class women (Dutta and Sircar, 2013; Livne, 2015). An intersectionality perspective that social divisions, such as class, religion and caste, is important to understanding the working of gendered social constructs and to deconstruct violent behaviour within households, which can also give insights into multiple marginality (Belknap, 2007; Garcia and McManimon, 2011). Any measure to prevent violence against women and girls should start by transforming the social environment, as most struggles for justice are limited by cultural and social norms that are complicit in sustaining gender hierarchies, pervading the legal and justice systems, and indeed wider society.

\section{Notes}

1 This chapter was motivated by the infamous gang rape of a young student on a bus in New Delhi; she later succumbed to her injuries, triggering a nationwide protest against this and other assaults on women, leading to changes in the legal (and social) dimensions of sexual violence against women. In 2016, Kerala witnessed a similar incident, known as the "Jisha murder case", leading to similar protests across the state.

2 Crime rate statistics reveal interesting details on the incidence and prevalence of different types of crimes against women. Reports of crime against women mostly relate to sexual violence (NCRB, 2015). Crimes directed specifically against women's sexuality are labelled "Crimes against Women" (NCRB, 2012) under two divisions - crimes against the Indian Penal Code (IPC) and those under Special or Local Law (SLL).

3 In numerous cases, the main offenders are women; for example, in the recent Solar Panel case the main accused were two women, including a popular actor, which attracted huge public attention.

4 Furthermore, evidence shows the relationship between the victim and the offender: in over 94.2 per cent of the cases, offenders were known to the victims; in 1.2 per cent of the cases, parents or close family members were involved, neighbours in 34.7 per cent and relatives in 6.9 per cent $(\mathrm{NCRB}, 2012)$. Victim-offender relationships may have implications for reporting such assaults.

5 A 14-year-old girl was groomed and blackmailed by a local bus conductor in the district of Idukki and subjected to sexual assault by several men while in captivity for 40 days.

6 The trial lasted for 317 days; it started after the special investigation team had investigated the crime for two and a half years, showing the protracted course of legal justice. 
7 However, in 2005 the High Court acquitted most of the accused, convicting only four of them. The third person on the accused list, Dharmarajan, disappeared on bail but was re-arrested in February 2013.

8 Until 2005, victims of domestic violence had limited legal recourse in the civil courts (divorce) and criminal courts (see Section 498A of the Indian Penal Code), as most legal recourses were linked to matrimonial proceedings; court proceedings were always protracted, and during these the victim was invariably at the mercy of the abuser. The Domestic Violence Act 2005 was brought into force on 26 October 2006.

9 Even a single act of commission or omission may constitute domestic violence - in other words, women do not have to suffer a prolonged period of abuse before taking recourse to the law.

10 These cases were uncovered in 2013. A group, including women, set up a fraudulent solar energy company (Team Solar) and used political contacts for financial appropriation by promising business partnerships or installing solar power units. This led to scandals of political misconduct, sexual allegations and large-scale bribery.

11 Such interventions to weaken evidence are common; for example, even in the widely publicized Soumya case, there were reports of attempts to weaken the initial forensic evidence and support for the accused from legal representatives from Mumbai.

12 Rape within marriage is not acknowledged as rape.

13 For example, on 9 February 2012 shocking revelations appeared in the media from Justice Basant, who had found some of the accused not guilty in 2005, blaming the victim and her family, asserting that all evidence pointed to it as a case of child prostitution, questioning the morals of her upbringing and her family (The Hindu, 2013c).

14 The term "institutional racism" was used in the UK in 2006 in the context of the racial murder of the black teenager Stephen Lawrence.

\section{References}

Adler, F. (1975). Sisters in Crime: The Rise of the New Female Criminal. New York: McGraw-Hill Publishing.

Agarwal, B. and Panda, P. K. (2007). 'Toward freedom from domestic violence: The neglected obvious.' Journal of Human Development, 8(3), pp. 359-388.

Alston, M. (ed.). (2014). Women, Political Struggles and Gender Equality in South Asia. Basingstoke: Palgrave Macmillan.

Bandura, A. and Walters, R. H. (1963). Social Learning and Personality Development (Vol. 14). New York: Holt, Rinehart and Winston.

Belknap, J. (2007). The Invisible Woman: Gender, Crime and Justice (3rd Edition). Belmont: Thomson Wadsworth.

Bourdieu, P. (2000). Pascalian Meditations. Stanford: Stanford University Press.

Bourdieu, P. (2001). Masculine Domination. Stanford: Stanford University Press.

Bourdieu, P. and Passeron, J. C. (1990). Reproduction in Education, Society and Culture, London: SAGE Publications.

Brownmiller, S. (1975). Against Our Will: Men, Women and Rape. New York: Simon \& Schuster.

Buzawa, E. S. G. and Buzawa, C. G. (2003). Domestic Violence: The Criminal Justice Response (3rd Edition). Thousand Oaks, CA: SAGE Publications.

Campbell, R. and Raja, S. (1999). 'Secondary victimization of rape victims: Insights from mental health professionals who treat survivors of violence.' Violence and Victims, 14(3), pp. 261-275.

Connell, R. (1987). Gender and Power: Society, the Person and Sexual Politics. Cambridge: Polity Press. 
Connell, R. (1990). 'The state, gender and sexual politics: Theory and appraisal.' Theory and Society, 19(5), pp. 507-544.

Devika, J. (2009). 'Bodies gone awry the abjection of sexuality in development discourse in contemporary Kerala.' Indian Journal of Gender Studies, 16(1), pp. 21-46.

Dutta, D. and Sircar, O. (2013). 'India's winter of discontent: Some feminist dilemmas in the wake of a rape.' Feminist Studies, 39(1), pp. 293-306.

Fineran, S. and Bennett, L. (1999). 'Gender and power issues of peer sexual harassment among teenagers.' Journal of Interpersonal Violence, 14(6), pp. 626-641.

Garcia, V. and Schweikert, E. J. (2010). 'Cultural images-media images: "doing culture" and victim blaming of female crime victims.' In: Garcia, V. and Clifford, J. E. (eds.), Female Victims of Crime: Reality Considered, pp. 3-39. Upper Saddle River, NJ: Pearson Education.

Garcia, V. and McManimon, M. (2011). 'Gendered justice: Intimate partner violence and the criminal justice system.' Contemporary Sociology: A Journal of Reviews, 41(6), pp. 835-836.

Gelles, R. J. (1983). 'An exchange/social control theory.' In: Finkelhor, D., Gelles, R. J., Hotaling, G. T. and Straus, M. A. (eds.), The Dark Side of Families: Current Family Violence Research, pp. 151-165. Thousand Oaks, CA: SAGE Publications.

Gelsthorpe, L. and Morris, A. (1990). Feminist Perspectives in Criminology. Buckingham: Open University Press.

Heidensohn, F. (1996). Women and Crime (Women in Society: A Feminist List) (2nd Edition). Basingstoke: Palgrave Macmillan.

Heidensohn, F. (2006). Gender and Justice. Gloucester, England: Willan Publishing.

The Hindu. (2013a). 'Crime rate highest in Kerala.' June 17. [Accessed July 2013] Available at: <www.thehindu.com/news/national/kerala/crime-rate-highest-in-kerala/article4822947.ece>.

The Hindu. (2013b). 'Ice cream Parlour Sex case is out of deep freeze.' 9 February. [Accessed December 2016] Available at: <www.thehindu.com/news/cities/Kochi/ icecream-parlour-sex-case-is-out-of-deep-freeze/article4394442.ece) $>$.

Hlavka, H. R. (2014). 'Normalizing sexual violence young women account for harassment and abuse.' Gender and Society, 28(3), pp. 337-358.

Hudson, A. (1990). 'Elusive subjects - researching young women in trouble.' In: Gelsthorpe, L. and Morris, A. (eds.), Feminist Perspectives in Criminology, pp. 115-124. Buckingham: Open University Press.

International Centre for Research on Women. (2006). Property Ownership and Inheritance Rights of Women for Social Protection - The South Asia Experience. New Delhi, India: International Centre for Research on Women.

Indian Express (2013). 'Suryanelli gangrape: Cong MP says victim moved "around as prostitute making money".' February 18. [Accessed December 2016] Available at: <www. indianexpress.com/news/suryanelli-gangrape-cong-mp-says-victim-moved-around-asprostitute-making-money/1075730/>.

Indian Express (2016). 'Which of the rapists gave you most pleasure, cops asked woman in horrific case.' November 3 [Accessed November 2016] Available at: <http://indian express.com/article/india/india-news-india/kerala-which-of-the-rapists-gave-you-mostpleasure-cops-asked-woman-in-horrific-case-3735100/>.

Jin, X., Doukas, A., Beiting, M. and Viksman, A. (2014). 'Factors contributing to intimate partner violence among men in Kerala, India.' Journal of Family Violence, 29(6), pp. 643-652.

Karmen, A. (2010). Crime Victims: An Introduction to Victimology. Belmont, CA: Wadsworth Cengage Learning. 


\section{Gendered violence and victimisation}

Kavil, R. (2012). 'Kerala sex scandals: Stolen girls of God's Own Country.' 19 February 2012. [Accessed July 2016] Available at: $<$ http://feministsindia.com/tag/ice-creamparlour-case/>.

Kodoth, P. (2010) 'The institutionalization of dowry in Kerala: Feminine identity, conjugal patronage and development.' In: Ravi Raman, K. (ed.), Development, Democracy and the State: Critiquing the Kerala Model of Development, pp. 192-193. London and New York: Routledge.

Krais, B. (1993). 'Gender and symbolic violence: Female oppression in light of Pierre Bourdieu's theory of social practice.' In: Calhoun, C., Lipuma, E. and Postone, M. (eds.), Bourdieu: Critical Perspectives, pp. 156-177. Cambridge: Polity Press.

Kumari, A. (2009). 'Crimes against women in Kerala: What do the trends reveal?' The Journal of Family Welfare, 55(1), pp. 18-30.

Livne, E. (2015). 'Violence against women in India: Origins, perpetuation and reform.' [Accessed December 2016] Available at: <www.cmu.edu/hss/globalstudies/images/ livne-gs-capstone-paper.pdf.>.

Lombroso, C. (1911). Crime: Its Causes and Remedies. Boston: Brown and Company.

Los, M. (1990). 'Feminism and rape law reform.' In: Gelsthorpe, L. and Morris, A. (eds.), Feminist Perspectives in Criminology, pp. 161-172. Philidelphia: Open University Press.

Mackinnon, C. (1989). Toward A Feminist Theory of the State. Cambridge: Harvard University Press.

Manorama Online (2016). 'Soumya murder: No death sentence, only life-term for Govindachamy ... ' September 16. [Accessed January 2017] Available at: <http://english. manoramaonline.com/news/just-in/soumya-murder-case-govindachamy-death-penaltysupreme-court.html>.

Melton, H. (1999). 'Police response to domestic violence.' Journal of Offender Rehabilitation, 29(1/2), pp. 1-12.

Messerschmidt, J. W. (2012). 'Engendering gendered knowledge: Assessing the academic appropriation of hegemonic masculinity.' Men and Masculinities, 15(1), pp. 56-76.

Mies, M. (1986). Patriarchy and Accumulation on a World Scale: Women in the International Division of Labour. London: Zed Books.

Morgan, K. and Björkert, S. T. (2006). 'I'd rather you'd lay me on the floor and start kicking me: Understanding symbolic violence in everyday life.' Women's Studies International Forum, 29(5), pp. 441-452.

Mukhopadhyay, S. (2007). The Enigma of the Kerala Woman: A Failed Promise of Literacy. New Delhi: Social Science Press.

National Crime Records Bureau (NCRB). (2013). 'National Crime Records Bureau, Ministry of Home Affairs (MHA).' Government of India. [online]. New Delhi. [Accessed on 25 August 2013] Available at: <http://ncrb.gov.in/>.

Panda, P. K. (2004). 'Domestic violence against women in Kerala.' Discussion Paper No. 86. Kerala Research Programme on Local Level Development, Centre for Development Studies, Thiruvananthapuram. [Accessed on 1 September 2013] Available at: <www. cds.ac.in/krpcds/publication/downloads/86.pdf>.

Purewal, N. K. (2010). Son Preference: Sex Selection, Gender and Culture in South Asia. London and New York: Berg.

Ryan, W. (1976). Blaming the Victim. 2nd Edition. New York: Vintage Books.

SAKHI (2004). A Study on Gender Based Violence in Kerala. A study submitted to the Department of Health, Government of Kerala: Sakhi Resource Center for Women, Trivandrum, India. [Accessed on 19 August 2013] Available at: <http://sakhikerala.org/ downloads/Gender\%20based\%20Violence\%20report.doc'. 
Shreekumar, S. (2007). 'The land of 'gender paradox? Getting past the commonsense of contemporary Kerala.' Inter-Asia Cultural Studies, 8(1), pp. 34-54.

Silvestri, M. (2006). 'Gender and crime: A human rights perspective.' In: Heidensohn, F. (ed.), Gender and Justice. New Concepts and Approaches, pp. 222-242. Devon, England: Willan Publishing.

Stanko, E. A. (1985). Intimate Intrusions: Women's Experiences of Male Violence. London: Routledge.

Stanko, E. A. (1990). 'When precaution is normal; a feminist critique of crime prevention.' In: Gelsthorpe, L. and Morris, A. (eds.), Feminist Perspectives in Criminology, pp. 173-183. Buckingham: Open University Press.

Straus, M.A. (1979). 'Measuring intra-family conflict and violence: The conflict tactics (CT) scales.' Journal of Marriage Family, 41(1), pp. 75-88.

Strinati, D. (2004). An Introduction to Theories of Popular Culture (2nd Edition). Abingdon, UK: Routledge.

Walklate, S. (1995). Gender and Crime: An Introduction. London: Prentice Hall and Harvester Wheatsheaf.

Walklate, S. (2004). Gender, Crime and Criminal Justice (2nd Edition). Devon: Willan Publishing. 


\section{Asset accumulation and Adivasis \\ Limits to legitimate capital}

\section{Introduction}

This chapter addresses social difference through the lens of minority social factors such as ethnicity, in relation to Adivasi citizenship within the dominant Kerala model of development. In the traditional sense, citizenship - particularly in democratic societies - denotes particular identities and practices that are framed within the "political" notion (i.e. in relation to the state) and linked to rights and responsibilities. As mentioned in Chapter 2, race and ethnicity as social divisions have rarely been discussed in Bourdieu's scholarship on class and social analysis. This chapter explores the challenges of and possibilities for the Adivasi communities in Kerala, particularly for Adivasi women, through the asset structure and livelihoods framework. In doing this it adopts a holistic approach to assets and livelihood so, based on Chambers and Conway's (1992) Livelihood approach, it constitutes both tangible and intangible aspects of capabilities and assets (material and social resources). The first part outlines pertinent issues in relation to race and ethnicity (in relation to minorities) within a Bourdieusian framework and notions of citizenship, while the second looks at Adivasi populations and their capital building. The third part discusses the data and findings from primary research; the final one offers the study's conclusions.

\section{Citizenship as identity and capital: a discussion}

Sociological explorations of race and ethnicity have focused on race through class and political relations, but they have done so mostly in terms of resource inequalities whereby they often label racial and ethnic minorities as an "underclass" (see Rex, 1970); neo-liberal approaches, meanwhile, have focused on "racism" and discrimination (see Miles, 1982) in relation to economic capitalism. These approaches therefore often promote deficit views of minorities in different contexts. The social constructs of race and class reproduction are consequently commonly viewed as being mutually exclusive and separate (Agger, 2006; Mills, 2003). Post-colonial discourses have shown how specific discursive constructions have been subject to the politics of representation through history and social tradition - for example, through the lens of orientalism (see Said, 1978). Race 
and racism therefore form patterns of cultural representation that are embedded within practices, discourses and subjectivities. In many ways, albeit without Bourdieu's work on capital addressing race issues directly, the concepts of habitus and cultural capital have parsed out the interactions of class, racial and ethnic disadvantages (Wallace, 2016; Reay, 2004;Rollock, 2012). Scholarship in Western societies pinpoints to a long history of deficit understandings in terms of resources and capital possessed by minority groups such as non-whites (Yosso, 2005; Reynolds, 2006; McKnight and Chandler, 2012). Research into how class interacts with race in relation to schooling shows how differential family habitus, differential possessions and the activation of cultural capitals influence academic achievement in the UK (Vincent et al., 2012). Social analysis becomes meaningful when it incorporates one's sum of capital and resources possessed rather than what they "lack" (Bebbington, 1999; Rollock, 2012) in relation to conventional notions of capital or resources. Conventional notions of capital as drawn from Bourdieu relate to consumption practices and patterns such as schemes of expression, acquired bodies of knowledge and social styles (Moore, 2008; Silva, 2005; Reay, 2004) of hegemonic groups in society.

McKnight and Chandler (2012) say that race, like habitus, is situational, contextual, historical and gradational. And just as habitus is socially constructed and culturally arbitrary, race is a product of social and historical construction at both individual and collective levels, while habitus and differentially valued capital reproduce inequalities rather than fracture them. For example, Carter's (2003) research among low-income African American and Latino youth shows how black cultural capital does not conform to conventional interpretations of cultural capital; consequently, it promotes deficit perspectives of capital. Drawing on Carter's work on black cultural capital, Wallace (2016) highlights the hierarchies of social status among black ethnic groups in a London state school, as forms of cultural capital possessed by black communities are not valued in British society. In short, Bourdieu's trinity framework deems race a significant indicator of how social reproduction occurs through white (hegemonic) privilege being maintained, which leads to a form of complicity by marginalised groups (Bourdieu and Passeron, 1990). Such forms of hegemonic practices concern how marginalised groups relate to the state and to other dominant groups through exploring discourses on citizenship.

The traditional conception of citizenship being linked to rights is based on Marshall's (1950) social libertarian premise of democracy, but now citizenship also is understood as a process that produces multiple practices and identities (Mouffe, 1992; Turner, 1997). Traditional citizenship based on liberal/social rights and the civic republican has indeed constructed citizenship as a status and a practice (Oldfield, 1990). From a human rights perspective though, citizenship includes numerous formal rights that produce and protect welfare and democracy. The meaning of citizenship as a status goes beyond legal rights, as the citizen's relation to the state ranges from struggles against economic and social exclusion and inequality to negotiations for participation in the public sphere. Citizenship also includes a status of well-being, which relates to indices of human dignity and autonomy as 
well as substantive freedoms and capabilities/entitlements (Sen, 1999). It also values diverse forms of cultural capital. A tradition of citizenship relating to "universalism", then, is questionable given claims about differences based on social divisions (Laclau, 1996). For example, the category "woman" itself represents a false universalism as social divisions such as race, sexuality, class and ethnicity have much significance for women's status as a citizen (see Lister, 2001; Kabeer, 2005). Thus, discourses and practices on the "politics of difference" strengthen the difficult but critical nexus between the universalism of human rights and the particularities of cultural and other differences.

In general, indigenous peoples are singularly affected by poverty globally (Hall and Patrinos, 2005; Kabeer, 2005; Mcneish and Eversole, 2006) and share basic similarities in histories through their relation to land (dis)possession and identities. Discussions on asset poverty have centred on the "adverse" incorporation of certain social groups (Du Toit, 2005) with regard to their material poverty and lack of assets. Drawing on notions of Bourdieu's capital and Sen's (1999) capabilities framework, several asset-based approaches treat assets not just as resources but also as an "agency" to transform such resources (Moser, 1998; Bebbington, 1999; Ellis, 2000; Moser and Dani, 2008). Social capital approaches (e.g. Coleman, 1994; Woolcock and Narayan, 2000) ${ }^{1}$ have informed asset-based studies in development debates that analyse forms of social networks. Extending this, proponents of asset-based policies argue that asset-building is crucial for expanding opportunities and to improving meaningful participation of different social groups in the development process. However, having the ability to exercise their agency is crucial as inequalities in power relations affect asset-building (Narayan et al., 2000; de Haan, 2008; Arun et al., 2013).

The ability to build assets depends on diverse factors and circumstances - for example, marginalised social groups such as Adivasis have long been affected by development planning throughout India. The Adivasis are the indigenous communities in India. Officially referred to as Scheduled Tribes (STs), they comprise around 8 per cent of the population. It has been pointed out that structural inequalities such as social groupings or gender can perpetuate asset inequalities and may affect asset-building (Narayan et al., 2000) - in particular, gender relations affect all aspects of livelihoods and well-being (Narayan et al., 2000). The thesis of the feminisation of poverty, which posits that more women experience poverty compared with men, has helped to bring out the nexus between gender and poverty in terms of extent, incidence and trends (Jackson and Pearson, 1998).

Feminists have argued for women's reproductive status - including time devoted to household care - to be included as a resource that is critical to their position regarding citizenship (Walby, 2001). This is because the public-private divide increases women's exclusion from full citizenship, though this varies over time and between societies (Lister, 2001). However, a mere gender analysis of citizenship is insufficient as other social divisions such because class, race and ethnicity, religion and disability interact with gender to (re)produce "unequal" or "differential" forms of citizenship, so it is difficult and even perhaps meaningless to make a universalist claim to feminist citizenship (Anthias and Yuval Davis, 
1989). Here, for example, differences between women are accentuated in the Kerala context, where Adivasi women's experiences vary from women in mainstream communities simply because their gender intersects with their Adivasi ethnicity, social grouping and resource structures. Gender issues in Adivasi societies are different from those in caste-based societies, which are more patriarchal in nature (see Banu, 2001; Dube, 1997), though, over time, social and economic changes have altered Adivasi women's status to more patriarchal ones, thereby devaluing the cultural capital and practices of Adivasi cultures throughout India. This has occurred in Kerala, where the average Adivasi woman possesses higher levels of literacy and health indicators compared with other Adivasi women in India; however, they still lag behind in these social indicators compared with women in general throughout the state. Therefore, this chapter argues that Adivasis' livelihood choices and practices are often not legitimated, or accorded symbolic recognition in the hegemonic Kerala model, and indeed in national development practices, which has consequences for gender. Such processes of misrecognition and acts of symbolic violence are consequences of the asymmetrical power relations ingrained in patterns of (mis)representation and subsequently embedded within practices, discourses and subjectivities, which therefore reproduces social and gendered inequalities.

\section{Adivasi livelihoods: unequal citizenship within the Kerala model}

Adivasis have distinctive identities and cultural systems, but they remain outside the hierarchical varna, or caste-based system. Any discussions of Adivasi livelihoods are challenging, as in many ways these people are irreducibly local in nature - varying across geographical regions, type of tribe and socioeconomic conditions, though there are recurring themes and patterns among them. For instance, even with a range of social protections (including constitutional measures), they persistently remain the most backward ethnic group in India, as is reflected through important indicators of human capabilities, primarily in health, education and work participation (see Arun et al., 2013), and their being entrapped in historical issues of contested land rights and exploitation. As seen from Table 8.1, Adivasis tend to participate in the labour market as landless labourers, with exhibiting higher work-participation rates, particularly through Adivasi women's high work participation rates, which is 36 per cent compared with only 15.8 per cent of women from the general category in the state (GOK, 2015).

Kerala's long history of robust forms of public action and social movements such as agrarian movements, organised democratic mobilisations against social hierarchy, high investment in social capabilities such as health and education, effective land reforms, the influence of leftist movements and a unique matrilineal system have all contributed to a higher order of social development of its citizenry. ${ }^{2}$ However, the highly acclaimed success factors of the Kerala model do not apply to the Adivasi population. The differential picture of human (and gendered) 
Table 8.1 Selected Indicators of Adivasis in Kerala and India

\begin{tabular}{|c|c|c|c|c|}
\hline & \multicolumn{2}{|l|}{ Kerala } & \multicolumn{2}{|l|}{ India } \\
\hline & General & $S T$ & General & $S T$ \\
\hline $\begin{array}{l}\text { Percentage of ST to Total } \\
\text { Population (2011) }\end{array}$ & 34.8 million & $1.45 \%$ & 1.25 billion & $8.6 \%$ \\
\hline Sex Ratio (2011) & 1084 & 1035 & 943 & 990 \\
\hline $\begin{array}{l}\text { Below Poverty Line } \\
\text { (55th Round NSS) }\end{array}$ & $25.5 \%$ & $37.3 \%$ & $37.1 \%$ & $52.2 \%$ \\
\hline (55th Round NSS) & $9.4 \%$ & $24.2 \%$ & $27.1 \%$ & $45.8 \%$ \\
\hline Literacy Rates & $93.9 \%$ & $75.81 \%$ & 74.04 & 58.96 \\
\hline Female Literacy Rate & $92.07 \%$ & $71.1 \%$ & $65.46 \%$ & $49.35 \%$ \\
\hline Male Literacy Rate & 96.11 & 80.76 & 82.4 & 68.53 \\
\hline Work Participation Rates + & 34.78 & 47.49 & 39.2 & 45.2 \\
\hline
\end{tabular}

+2011 Census figures

Source: Census (2011); GOK (2015)

capabilities in Kerala is evident in various demographics. The Adivasi population of Kerala forms 1.14 per cent of its population and is mostly concentrated in the districts of Wayanad), Idukki and Palakkad (mostly the region of Attapady). Their concentration in hilly and remote regions exacerbates issues concerning isolation and disadvantage. Incidences of poverty among the Scheduled Tribes are about three times that of the state population. According to the 2011 Census, the literacy rate among the Scheduled Tribes in the state was 75.81 per cent compared with 58.96 at the national level. In India as a whole, the sex ratio of Scheduled Tribes is 990 per 1000 males, while in Kerala there is a favourable sex ratio to women (1035 females per 1000 males), it lags behind the sex ratio for the general population. The child sex ratio is 949, showing an unfavourable ratio for girls. Hunger and ill health are of serious concern in the state, and numerous starvation deaths and malnourishment in the Adivasi belts are reported frequently. Kerala has the lowest rates of infant mortality in the country, with 12 deaths per 1000 population (GoK, 2015); however data for the ST population from the 2001 Census reveals infant mortality was 60 per 1000 population. ${ }^{3}$ Similarly in Kerala, D'Rozario (2013) observes that among Adivasi children age 12 months or less, 9.1 per cent are severely underweight and 32.2 per cent suffer from severe stunting. As already alluded to, the high work-participation rate for Adivasis is mainly due to Adivasi women, for whom this rate is 36 per cent compared with only 15.8 per cent in the state. For males it is 55.14 per cent and 47.58 per cent for the state - hence, still more, but not as vast a difference as that between the women (GOK, 2015).

Table 8.2 shows the labour force participation of the ST population in Kerala, compared to the general population as per the 2011 Census Report. The percentage of agricultural labourers to main workers is very high for the Adivasis, at 59.49 per cent, compared to 14.18 per cent for the general population (see Table 8.2). This shows that the majority of the Adivasi population are assetless 
Table 8.2 Labour Force Participation Rates among STs (\%)

\begin{tabular}{lll}
\hline & General & STs \\
\hline Main Worker & 27.93 & 33.29 \\
Male Main Workers & 44.8 & 44.24 \\
Female Main Workers & 12.37 & 22.71 \\
Percentage of Agricultural Labourers to Main Workers & 14.18 & 59.49 \\
Work Participation Rate & 34.78 & 47.49 \\
\hline
\end{tabular}

Source: GoK (2015)

workers. The Adivasi sub-plan concept, introduced in the seventies in the state, could never be fully implemented because of vested interests, such as other large landowners (Kalathil, 2004). The general crisis in the agricultural sector and nonimplementation of the Alienated Adivasi Land (Restoration) Act of 1975have compounded Adivasis' vulnerabilities. Despite decades of modernisation policies and programmes in Kerala, there are stark differences in capabilities and entitlements that still exist throughout the state. Overall, though, the Kerala Adivasi woman has higher levels of human capital compared with her female counterparts, but she lags much behind the average Kerala woman in terms of literacy and other social indicators. Thus, the Adivasi woman's female capital is very much disadvantaged, and it is subject to erosion from both human and other forms of capital, as we will see later.

Like most indigenous communities, Adivasis often regard natural resources as central to their existence; hence, their dependence on land as a livelihood resource is crucial. As in the wider context, Kerala's Adivasi people have been victims of land dispossession, in many cases because of a lack of appropriate evidence; this has rendered them assetless ${ }^{4}$ (Kalathil, 2004) and reduced them to landless labourers. There has been much discussion about the incorporation of Adivasis within the Kerala model (see Steur, 2010), whereby they were regarded as "outliers" of the model (Kurien, 1995) or were deemed to have been dispossessed, marginalised or victimised within the overall development process (Parayil, 2000).

\section{Data and findings}

The present study was based on a triangulation of research methods including surveys, case studies, in-depth interviews, focus group discussions (FGDs) and discourse analysis, which were all conducted between December 2008 and January 2010. The study regions consist of selected "hamlets" from panchayats (local administrative units - in total there are 991 in the state) within the Adivasidominated district of Waynad. The selected panchayats are Noolpuzha, Bathery, Manathavady, Mepadi, Nenmeni, Pulpally, Thirunelli, Poothadi and Thondakkadavu. A total of 120 households were included in the quantitative survey, comprising 36 Kattunaikans, 25 Adiyas and 59 Paniyas. Qualitative methods of interviews, case studies and focus groups were conducted; these involved 38 women and 27 
men. The other key sources of information were interviews with key political leaders, Adivasi activists, and social and anganwadi (primary care workers) staff from the study region. This information was gathered through discreet meetings because of hostile political activism among and towards Adivasi groups in the state. The specific configuration of the local contexts and the challenges involved in unravelling the power relations that exist within them should be acknowledged. Firstly, the specific nature of Adivasi livelihoods and the challenges it poses for social research perhaps should be mentioned. Discourses on and engagement with Adivasi identity and citizenship often highlight the process of "othering" through self-constructed binaries of "us" and "them". In general, the research process revealed how the respondents from Adivasi communities viewed the general (non-Adivasis) population as "aliens" or "outsiders" and, in most cases, with suspicion and a lack of trust. Interactions would prove much easier in Adivasi areas in which interventions by community organisations played an active role, though caution was exercised not to bias the research findings, through cross-checking with other sources. Secondly, issues of exclusion and inclusion are to be framed within the cultural and social contexts of the Adiviasi system of livelihoods - for example, access to education, health and work is often seen from a "mainstream" universal perspective of development, equality and justice.

\section{The politics of (mis)representation}

Adivasi communities are heterogeneous - particularly in relation to customs and economic choices - yet are often homogenized within policy structures and discourses. Numerous Adivasi groups are prevalent in the state, but for this study four major groups that are distinct in terms of cultural systems and ethnicities were identified. Such distinctions also highlight differences in social hierarchy, historical origins and economic status (e.g. land ownership and occupation). Adiyas are mostly landless labourers who were originally slaves. The term "adiya" stems from rules on social distance in a caste society ("ar" = six; "adi" = feet in distance, to avoid social pollution). The forest-based Kattunaikans (" $k a d u$ " = forest; "nayakkan" = leader) depend on forests for their livelihoods as settled cultivators, collectors of forest produce and weavers. Kattunaikan women also engage in forest-based work (e.g. accompanying their men, as a group, to collect turmeric, honey and "pooppal" (used for dye production). The Paniya ("pani" = working in coffee plantations as bonded labourers) are dark-skinned, long-headed people of short stature. The Uralis, a term derived from the words "ur", meaning village, and "al", meaning person, were previously engaged as shifting cultivators but have moved to settled cultivation, wage labour and the collection of forest produce or weaving.

Despite the diversity of these social groups and their livelihood systems, their economic and social opportunities are shaped by the state's macro policies and socio-economic changes. As with other domestic dwellings in the state, changes in cropping patterns, modernisation of agriculture practices, the seasonality of agriculture and market fluctuations for agriculture output (see Chapter 3) have led 
to increased economic vulnerability of Adivasi households. For example, agricultural wage labour, primarily in rice cultivation, has been the sole occupation of Adiya and Paniya women; in this, they engaged in tasks such as transplanting, weeding and harvesting for, on average, 80 days per year. Changes in cropping patterns not only decreased their number of working days but also lowered their daily wages (i.e. from ₹90 to ₹60). Thus, these changes have had a gendered impact, as less demand for labour and elastic wage rates have obviously affected their availability of work and these women's income. Moreover, broader changes in cropping patterns have changed the system of wage payment in rice cultivation. "Pathambu", a traditional practice of payment in kind (i.e. rice as wages), has long been followed as a payment practice during the harvesting season. This is the preferred choice for food supply among Adivasi groups as it means households do not have to engage with market forces to obtain food grains. However, this has given way to the monetary-wage system, amplifying food insecurity among these communities. The general decline in the agricultural sector has affected the livelihoods that relied on wage labour rather than income-generating asset activities. Recent interventions such as those from self-help groups (SHGs) have helped households (through women) obtain loans to purchase goats and hens and thus diversify their livelihood strategies; however, this has led to increased indebtedness as they have been unable to make repayments due to increasing household and food expenses, including medical expenses.

Political and social capital, as in the ability to engage in political and social participation, is quite important in livelihood frameworks. Despite robust political activism in campaigning for land rights, the respondents in the selected study areas displayed little awareness, and much disinterest, in political issues. Ravi Raman, (2002) notes that despite a record of successful land reforms and pioneering decentralisation initiatives, the marginalised communities of Kerala have yet to fight for a decent livelihood through an alternative front quite removed from the established Right-Left domains in the state. The state has contained the Adivasi movement through several means (Sreekumar and Parayil, 2006), and though some groups have participated in the struggle for land, organised by the Adivasi Gotrasabha in Muthanga and the Adivasi Kshetra Samithi, this initiative has not been sustained in any way. ${ }^{5}$ Arguably, the Adivasis' historical marginalisation has been compounded by their lack of capabilities and entitlements. Their lack of ability to engage in politics and their absence of political participation - by both men and women, at all levels - somewhat paradoxically reinforces their persistent marginalisation.

Adivasi activists (e.g. K. S. Janu) launched the Adivasi land agitation to fight for the cultivable land lost with settlers' encroachment. Increased demands for a settlement outside the Kerala Restriction on Transfer by and Restoration of Lands Bill of 1999 led to widespread protests, political mobilisation and violence in support of struggles such as those by the Adivasi Dalit Samara Samithi (ADSS) and against such happenings as the ensuing "Muthanga" episode. ${ }^{6}$ Another campaign, the Chengara Land Struggle, demanded permanent ownership of agricultural land through the transfer of ownership from the Harrison Company to the Dalits and 
Adivasis. Led by Sadhu Jana Vimochana Samyuktha Vedi (SJVSV), the campaign seeks to reclaim ownership of land from the Harrison Malayalam Private Ltd Estate, where more than 20,000 people entered the area with makeshift arrangements but face the dangers of hunger, epidemics and attacks.

In one of the interviews during the author's fieldwork in 2004, the Adivasi leader K. S. Janu, stated:

Groups are fragmented with little solidarity as we are struggling for basic rights and needs such as food and work, so any long-term strategic mobilization for land is bound to take time, but we will not give up until every Adivasi household is given five acres of agricultural land. Indigenous communities such as Adivasis are the only people who never trade land as this is our livelihood and identity. We have been ostracized from our own land, and we will fight for this.

The clear demand for land rights has not been met by the state or political groups. Ownership of land is the single source of marker, identity and struggle for Adivasis, as evidenced in many indigenous movements. Janu's statement similarly shows land as key capital for Adivasis - not just for economic rights but also for cultural and political identity. Traditionally, tribal populations throughout India who enjoyed land rights did not possess land ownership deeds as they did not engage in the sale or transfer of land. However, mainstream groups have exploited this by appropriating these lands through illegal means, through force or by meagre incentives. The current Adivasi struggle for land has been hindered in many ways. For example, due to weak organisation of political movements, distinct Adivasi hierarchy and lack of leadership formation, traditional Adivasi leaders have lost their relevance and power in the community to organize groups. Others are divided into different political parties without real political consciousness, attracted by temporary benefits offered during elections and conventions.

However to some extent, Adivasi women's participation in social and political activism (along with other marginal groups) is visible - for example, the ecofeminist struggles of the Narmada Bachao Andolan movement in western India and anti-Cococolanization campaigns in Kerala. ${ }^{7}$ As Rowse (2000) argues, the politics of indigenous citizenship is a struggle not only for rights but also about ways of being present and effective. This is demonstrated here in the Kerala context, where some Adivasi groups have engaged with struggles for both their own rights over land ownership and in wider anti-globalisation struggles. As these struggles have been effective and visible within the Kerala model, these are undermined through denial of basic rights to land and led to symbolic violence and misrecognition of the Adivasi identity, as is discussed below.

\section{Symbolic violation and physical violation of cultures and bodies}

Evidently, this context has seen continual struggles for economic livelihoods, "adverse" incorporations into the Kerala model, and exploitations of economic and social vulnerability. Furthermore, attitudes concerning "othering", sexual 
exploitation and the criminalisation of Adivasis have acted as exclusionary forces. Even more specifically, incidences of women workers being sexually exploited by employers and male co-workers in the workplace are very common, as is women being left behind in the hamlets. With high dropout rates of girls after primary school, girls are sometimes sent to other regions as domestic maids for a small payment, where some become trapped in prostitution. Increased media attention on the sexual exploitation of Adivasi women in Kerala has shown how this often takes the form of prostitution or abuse by state officials (Kalathil, 2004). Physical and financial exploitation at the workplace is also quite common, mostly of migrant workers as they are more vulnerable in mainstream communities. A steady rise in single mothers is another trend, as young women are often cheated into having sexual relations with men from outside communities but are subsequently abandoned. Often the victims and their families become silent partners of such exploitation and, in most cases, are denied justice within formal police or legal procedures. Victims' families often become complicit in this exploitation by accepting bribes from offenders, help with aborting pregnancies etc. Clearly, Adivasi girls and women are hemmed in interlocking systems of hierarchy, power and exploitation. Although the indigenous Adivasi cultures do not conform to the caste structure of Hindu society, gender relations are subject to double or even triple patriarchy through their gender, Adivasi identity and age. Increasingly, the patriarchal practices Adivasi households adopt further subjugate women to intrahousehold gender hierarchies, while women and young girls are often subject to sexual abuse by "outsiders"; and often their families are complicit, along with other legal and institutional authorities, in settling such cases through monetary compensations.

Of the men in Kerala, gambling, drug abuse and alcoholism are common. Such behaviours and addictions deplete household incomes and invite constant domestic arguments and community fights. The telling narrative of a nine-year-old summarises the intra-household struggles and allocations of meagre incomes.

When mother sends me to the grocery shop to buy household items, I always return any change from the transaction, but not so in the case when my father sends me. This is because mothers save any money for our welfare, but fathers waste it on alcohol, kanja and beedis and, then beat mums.

Households also bear the brunt of the criminalisation of forest resources. Adivasi youth are used as carriers in illegal activities such as illicit liquor sales, cultivation, guarding "gangs" plantations and plundering forest wealth (e.g. sandalwood). Often these youth are ultimately victims of such crimes, being killed for giving evidence or used as scapegoats, which perpetuates the general taboo that Adivasis are criminals; consequently, they continue to be treated with suspicion. In many hamlets, we found such young men feeling disillusioned, turning to drugs and alcohol, and getting involved in fights within the household and hamlets. Their behaviours led to women taking on more economic responsibility for taking care of both them and meeting household expenses. This general distruct of Adivasis also prevents Adivasi families from being entrusted with social responsibilities 
and leadership roles - for example, in self-help groups or the beneficiary committees of panchayat projects.

Such experiences and attitudes, exacerbated through the "us" and "them" binaries and rendering the "othering" process more explicit, mean the Adivasi population generally refrains from interacting with external communities. With all this, women and their bodies become silent bearers of sexual exploitation, as noted. Recently, women's SHGs have been actively mobilising Adivasi women, but a sustainable participation that meets their practical and strategic needs is far off. Based on research on SHGs in rural Bolivia, Maclean (2010) reports that as women's social capital takes the form of bonding capital, conventional assumptions that social capital can be used to promote income generation can lead to contradictory effects for women. For Bourdieu (1990), the effects of habitus, field, capital often leads to misrecognition through acts and processes of symbolic violence. In the Kerala context, the act of imposing arbitrary meanings on gender and social identities, such "misrecognition" of the arbitrariness of power relations, serves as their reproductive function; and here, it is where both general Adivasi and gendered Adivasi inequalities are continually reproduced within the Kerala model. This is also s evident in the processes of gendered asset structures outlined below.

\section{Gendered asset structures and outcomes}

Tangible or material assets comprise natural, physical and financial types. Dependency on natural resources (e.g. land) as a livelihood resource is important among indigenous communities, yet land dispossession (i.e. erosion of land ownership through different means) is rampant. Table 8.3 shows the ownership/control of some assets by type of Adivasi and gender. Being dependent on wage labour, Paniyas and Adiyas have no or little ownership of land, though their household dwellings are natural assets. These are sometimes owned by women, particularly in hamlets where the state has provided dwelling plots; for example, 25 per cent of Adiya women and 50 per cent of Paniya women own their housing plots. Living close to forest lands, Kattunaikans possess land resources where 25 per cent of women own their house and land. However this ownership is not legal because of "unrecognized" title ( $p a t t a$ ) deeds, where practices of land dispossession are

Table 8.3 Household Asset Portfolio, by Type of Adivasi and Gender (\%)

\begin{tabular}{|c|c|c|c|c|c|c|}
\hline & \multicolumn{2}{|c|}{ Natural } & \multicolumn{2}{|c|}{ Physical } & \multicolumn{2}{|c|}{ Financial } \\
\hline & $M$ & $F$ & $M$ & $F$ & $M$ & $F$ \\
\hline Kattunaikans & 23.1 & 25 & 0 & 17.7 & 21.7 & 10.2 \\
\hline Irulas & 32.7 & 0 & 0 & 10.9 & 13.1 & 27.6 \\
\hline Adiyas & 9.6 & 25 & 0 & 12.6 & 26.1 & 21 \\
\hline Paniyas & 34.6 & 50 & 0 & 58.8 & 39.1 & 41.2 \\
\hline Total & 100 & 100 & 0 & 100 & 100 & \\
\hline
\end{tabular}

Source: Arun et al. (2013) 
common. In most of the sample areas, the proximity of Adivasi lands to forests makes them prone to attack from wild animals, and many households have lost members as well domestic animals. Thus they are restricted in their livelihood options that are based on cultivation. Although protection through measures such as electric fencing and trenches exists, these are not so effective because of limited maintenance. Thus, although households have a certain asset portfolio, these are not translated into productive sources of income because of structural and other constraints. Hence development policies do not provide support for sustainable income generating activities for such groups, particularly the Kattunaikers who are dependant on forest resources.

In the Attapady region of the Palakkad district, Irula families who possess small plots of land, valued at 50-1.50 acres, engage in cultivating food crops like ragi, maize and vegetables. Land ownership is mostly by men (32.7 per cent), but levels of cultivation is declining because of poor water resources, frequent attacks by wild animals and the amount of time spent in paid employment. Further, the lack of support from the local agriculture office (krishi bhavan) is an example of an insensitively formulated policy to providing critical support to Adivasi agricultural practices. A typical example of such poor support policy can be see through the provision of hybrid seedlings of crops such as bananas, which use chemical fertilizers, pesticides and water. Dry-land organic crops are more important to Adivasi livelihoods in terms of food, nutrients such as iron and eco-friendly practices. Often these schemes are availed by Adivasis but are given to other (outsider) groups, showing exploitation of resources. In other cases, arrears in land tax have led to subsidies being denied from the Krishibhavan. Also, notably, women who take up homeland farming do not approach, nor are they approached by, these farm service providers. Thus despite significant expenditure on grants and subsidies, the programmes have not benefitted groups such as the Irulas (Kalathil, 2004) as the cultivation needs of Adivasi farmers, including that of women, are not met through mainstream agricultural development policies. Moreover, discussions with the farmers revealed that indigenous cultivation practices followed in such regions are not valued or integrated within such policies.

As much as material assets are important, intangible assets such as social and human capital are vital for the Adivasis' asset base, as they provide sustenance throughout their livelihoods. These assets directly impact the development of other assets such as political, social and financial capital. Discussions with the respondents, and observations of hamlets, reveal that they are being conditioned to economic and food insecurity, and often accept deprivation as a "norm" and a form of inter-generational transfer - for example, the prevalence of underweight children and ill health. High levels of morbidity exist, mainly from anaemia and poor personal hygiene. In short, the Adivasis' entire life cycle is characterized by ill health. ${ }^{8}$ Examples of health issues that were mentioned in this work are scabies, jaundice, cancer, leprosy, tuberculosis, seasonal viral fever, rheumatism and asthma, some of which are passed on to children. Hamlets located near the townships reportedly have various venereal diseases. Physical disability cases are increasing, mostly for males who have injuries from accidents at work. The 
neglect of women, their poor treatment and increased alcoholism and substance misuse by men have forced many women to become primary earners and carers (e.g. girls withdrawing from school to fulfil caring responsibilities). Moreover, early marriages for girls are common, and these girls often have little knowledge of mainstream practices regarding safe pregnancies and childbirth. Marriage practices have been transformed through adopting more mainstream patriarchal norms such as dowry, patrilocal attitudes, son preference and male bias. Thus, Adivasi societies have moved to more group-based, patriarchal systems (see Banu, 2001), relegating women to the subjugated domesticated sphere. However, their material incapacities often lead to gendered vulnerability in both daily and long-term spheres.

Many households did not recognise education or human capital as an important capital or route to developing capabilities. Despite having access to a large network of educational institutions from state schools and multigrade learning centres (MGLC) in the study areas and the rigorous efforts of the Tribal Development Offices to encourage education, dropout rates are high. One Anganwadi (local social worker) worker reported that the

dropout numbers for girls are more than for boys as girls are forced to stay at home to undertake household responsibilities, married off or seen as economic liabilities compared with boys. This was also due to the notion that higher dowry was required for educated girls, and to find suitable grooms.

Mothers lamented how, despite their children being good academic achievers in school, the expenses to meet secondary school education and the long distance to secondary schools made them decide to withdraw girls from school after puberty age. Another social worker said that 'they do not see how education can help them get jobs without paying bribes or seeking recommendation, so do not pursue paid formal sector work as an option'.

The economic context also dictated educational choices - for example, in the areas of Muthanga, Thonikkadav and Thirunelli panchayats, migrant work has become a livelihood option for men. With irregular work opportunities in their own regions, many Adivasis move to the border state of Karnataka as seasonal workers in ginger cultivation. This leads to girls ending their education to take up household responsibilities and rear livestock, because mothers go for daily waged work. In previous research (e.g. Arun et al, 2013), social and physical assets were deemed very significant in explaining the vulnerability of Adivasis. An interesting observation is that the incidence of shock is less likely if a household owns a physical asset. More specifically, it is 23 per cent less likely for a household that owns any form of physical asset to experience an adverse shock than it is for a non-ownership household (Arun et al., 2013). Despite significant programmes for housing and success in meeting annual targets for Adivasi welfare programmes, their suitability and quality leaves much to be desired. One SHG member stated:

Although the newly constructed homes have electricity connections, many have been disconnected due to non-payment of bills or faulty systems. 
Though the house plan includes toilets, nearly 90 per cent of the houses do not include these. Responses included insufficient grants or cases where the grant was shared between the contractor and the house owner, in a proportion of $4: 1$.

This not only causes personal and environmental hygiene issues, leading to ill health of members, but also illustrates misuse of funds under "development planning". Moreover, households have neither adequately sized nor decent quality housing and infrastructure, which further affects people's ability to use their homes as a physical asset to transform their livelihoods (e.g. diversification of income such as extensions, use of space for activities that pursue economic generation such as tailoring). Some women have learnt tailoring but have not been able to pursue this as a source of income generation.

Research also shows weak evidence for the claim that financial assets reduce the likelihood of household incidences of shock (Arun et al., 2013). The financial asset base of Adivasi households primarily consists of income from waged work in farm and non-farm sectors, or income from one's own farming, which largely depends on the seasonality of employment. Thus women earn regular incomes from waged labour and contribute to financial assets through borrowing from various sources. Borrowing of food materials (groceries) from petty shops is repaid during the working/harvesting season. Most debt accounts are subject to manipulation from money lenders, especially given the illiteracy and poor accounting skills of the Adivasi women, which compels them into a vicious cycle of debt from various sides. However, this temporary debt relief actually perpetuates longterm debt as the households do not then have any income from their land. In Attapadi, during the off-peak season, it is common for households to obtain loans from informal moneylenders (known as "Blade") from the neighbouring state of Tamilnadu. This is seen as a simple procedure compared with loans from formal institutions. $^{9}$

The unequal participation of and development outcomes for the Adivasi communities relate to the notion of habitus, which carries the notion of history noted as 'embodied history' by Bourdieu (1990, p. 56). Here, for similar groups (including Adivasis), the same habitus (e.g. Kerala model) can generate different outcomes (Lawler, 2004). This is because mainstream notions of development do not integrate or legitimise Adivasi needs, so forms of Adivasi capital are gained, valued and legitimated, and they can be converted into economic capital to achieve sustainable livelihood outcomes. For example, there is mixed evidence for the benefits derived from participation in different types of social networks among Adivasi households in Kerala (Arun et al., 2013). However, specific types of women's participation in SHGs operated by local NGOs, such as Shreyas and Gandhi Sevak Samithi, can lead to income generation, which is a conversion of social capital into economic capital. Overall, without the effective use or ownership of any economic or financial assets, most households cannot pursue sustainable livelihood strategies; furthermore, they exhibit strong debt patterns and possess inadequate social and human capabilities to participate in the economy and in society as full citizens. 
Effective social and political participation is linked to the notions of social inclusion and active citizenship (Lister, 2001). Thus concerns of equality, employment and welfare are key to legitimising identities and cultural capital of marginalised groups within the Kerala model, which has so far enabled the acquisition of capital for dominant agents, and this has allowed them to reproduce their dominance. It is critical to redress such forms of unequal power relations and build asset structures within development paradigms through the hegemonic narrative of the Kerala model. Equally important is to recognise and challenge the hitherto limited symbolic recognition of Adivasi cultures and social practices within such development debates through forms of collective activism which may help in defining and achieving sustainable livelihood outcomes for such marginalised groups.

\section{Conclusion}

Bourdieu's discussion on capitals related to the structure of the economic context and its materiality, thus shedding light on society via the movement of "capital" through social spaces. Here, for example, we see how the Adivasi identity and cultural capital is non-existent within the Kerala model, except through their struggles, deficits and incapacities. The persistent structure of domination upheld in the Kerala model of development is perpetuated through, as applied herein, Bourdieu's symbolic violence. This form of violence is 'censored, euphemized, that is, misrecognizable, recognized violence' (Bourdieu, 1990, p. 126). By acquiring different forms of capital, dominant agents in the Kerala model maintain the ability to reproduce their dominance. This dominant group defends the integrity of what Bourdieu labels "doxa" - unquestioned beliefs that are embodied in actions and feelings but seldom formulated in words, so they are accepted as beyond possible contestation and are resistant to modification (Crossley, 2001).

As Moser and Dani (2008) suggest, social policies need to distinguish between first-generation and second-generation asset accumulation. The former is based more on welfare-based poverty-reduction policies and seeks the provision of human, physical and financial capital through educational, housing and employment programmes. The latter strengthens accumulated assets through citizenship rights, security, governance and institutional accountability. Here the provision of social and economic infrastructure and services modelled on the mainstream notion of "developmental needs" through housing, public distribution systems, health or educational institutions is not sufficient to guarantee asset-building. Instead, this approach needs to be sensitised to the needs of Adivasi groups for example, through specific policies to strengthen the nature of social networks among Adivasi groups, which may address wider issues of exclusion (e.g. land ownership, the criminalisation of Adivasi youth) and strengthen citizenship participation. Social citizenship that moves beyond the state should recognise the agency of citizens (Cornwall and Gaventa, 2001), whose participation should be included in the nexus of basic human rights (see Lister, 2001). Differences between Adivasi groups must be recognised. These are often characterized by a 
distinctive social hierarchy that defines social and gender roles and plays a crucial determinant of economic assets and access to decent livelihoods.

Development intervention policies must therefore consider specific ethnic, social, economic and cultural dimensions of different social groups; hence, they must avoid a "one size fits all" approach. Presently, most developmental policies concerning Adivasi welfare do not address their specific needs, as neither are they consulted at the local level planning structures. What is required, besides understanding, information and feedback, is the sensitisation of policies and the responsiveness of institutions grounded in welfare and democratic principles not based on preconceived notions of "development" or "modernisation" ideologies. Social policies that have been effective elsewhere in the state, such as the Kudumbashree programme, could be successful here but only if they are tailored to the specific needs of Adivasi women. Other policies at the panchayat level need to involve more women to strengthen their social and political participation so the women can become more effective citizens within a context that is well acclaimed for its social development experiences and capabilities.

\section{Notes}

1 Woolcock (1999) distinguishes between two types of ties in social capital: bridging (weaker ties) and bonding (stronger ties).

2 Kerala's success is contributed to redistributive measures and welfare provisions (Parayil, 2000; Franke and Chasin, 1994) and unique historical processes (Tornquist, 2000). Yet concerns linger about its sustainability because of its low economic progress, increased emigration and high unemployment.

3 In May 2016, Prime Minister Narendra Modi compared the state of the Kerala's ST population to that of Somalia, leading to much controversy.

4 Transactions were made without paying any price or at nominal prices through the sale of commodities such as salt, liquor and tobacco, with or without their conscious concurrence.

5 Some of the prominent Adivasi land campaigns in Kannur since 1999 led by Adivasi Vimochana Munnani are the Muthanga land struggle in 2001, following the shocking death of 32 Adivasis from starvation, which forced the Adivasis in Wayanad to renew their struggle for land; the Aralam Farm Protest in 2006 against the LDF government's ecotourism project, depriving land for the Adivasis; and the Aripa Bhoomisamaram in 2009.

6 The basic demand to give alternate land to rehabilitate the landless Adivasis was agreed on by the then-government on 16 October 2001. A total of 53,472 Adivasi families $(22,491$ landless and 30,981 with less than one acre) were eligible to receive one to five acres of land each. But after a year, only 1 per cent of the Adivasi families identified received only 1.6 per cent of the total "alternate" land identified as available for distribution. Thus, Janu and another 500 Adivasis, on 4 January 2003, went to the Muthanga forest areas in Wayanad to build huts, dig wells and start cultivation. This region forms part of the Wayanad Wildlife Sanctuary, which caught the attention of the central government and protests from environmentalists, leading to violence and disturbances.

7 The struggle against the Plachimada Coca Cola Plant was launched on 22 April 2002, as the livelihood resources of the region were affected. There was a symbolic blockade and an ongoing picketing/dharna, mainly by the Adivasis, particularly women and children, belonging to Wayanad, Kannur and Nelliampathy. The movement has been successful in 
terms of the political and social attention drawn to the issue as well as the intervention by the courts and political authorities.

8 The recent deaths of young infants in the Attapady region have attracted attention and calls for integrated policy packages.

9 Only two-thirds of the total loan is given; the rest is seen as commission, with a weekly remittance of 100 .

\section{References}

Agger, B. (2006). Critical Social Theories. Herndon: Paradigm Publishers.

Anthias, F. and Yuval-Davis, N. (eds.). (1989). Woman, Nation, State. Basingtstoke: Palgrave Macmillan.

Arun, S., Annim, S. K. and Arun, T. G. (2013). 'Overcoming household shocks: Do assetaccumulation strategies matter.' Review of Social Economy, 71(3), pp. 281-305.

Banu, Z. (2001). Tribal Women Empowerment and Gender Issues New Delhi: Kanishka.

Bebbington, A. (1999). 'Capitals and capabilities: Framework for analysing peasant viability, rural livelihoods and poverty.' World Development, 27(12), pp. 2021-2044.

Bourdieu, P. (1984). Distinction: A Social Critique of the Judgement of Taste. Cambridge MA and London: Harvard University Press.

Bourdieu, P. (1990). The Logic of Practice. Stanford: Stanford University Press.

Bourdieu, P. and Passeron, J. C. (1990). Reproduction in Education, Society and Culture (Vol. 4). London: SAGE Publications.

Carter, P. L. (2003). 'Black" cultural capital, status positioning, and schooling conflicts for low-income African American youth.' Social problems, 50(1), pp. 136-155.

Chambers, R. and Conway, G. R. (1992). 'Sustainable rural development: Practical concepts for the 21st century.' IDS Discussion Paper No. 296. Brighton: Institute of Development Studies. [Accessed on 21 August 2013] Available at: <www.ntd.co.uk/ idsbookshop/details.asp?id=35>.

Coleman, J. S. (1994). Foundations of Social Theory. London: Harvard University Press.

Cornwall, A. and Gaventa, J. (2001). 'Bridging the gap: Citizenship, participation and accountability.' PLA Notes, 40, pp. 32-35.

Crossley, N. (2001). The Social Body: Habit, Identity and Desire. London: SAGE Publications.

D'Rozario, A. C. (2013). 'Deaths of unnamed children: Malnutrition and destitution among Adivasis in Kerala.' PUCL vs OuI and others, May (WP No. 196 of 2001). [Accessed on 7 December 2016] Available at: <www.righttofoodindia. org/data/research_writing field_reports/Deaths_of_unnamed_children.pdf.>.

de Haan, A. (2008). 'Citizens, identity and public policy: Affirmative action in India.' In: Dani, A. A. and de Haan, A. (eds.), Inclusive States: Social Policy and Structural Inequalities, pp. 225-247. Washington, DC: World Bank.

Du Toit, A. (2005). 'Forgotten by the highway: The sociology of chronic poverty in South Africa: Challenges for action and research.' Chronic Poverty Research Centre (CPRC) Working Paper No 56. [Accessed on 18 August 2013] Available at: $<$ http://papers.ssrn. com/sol3/papers.cfm?abstract_id $>$.

Dube, L. (1997). Women and Kinship: Comparative Perspectives on Gender in South and South-East Asia. New York: United Nations University Press.

Ellis, F. (2000). Rural Livelihoods and Diversity in Developing Countries. Oxford: Oxford University Press. 
Franke, R. W. and Chasin, B. H. (1994). Kerala: Radical Reform as Development in an Indian State (2nd Edition). New Delhi: Institute for Food and Development Policy/Food First Books. Government of Kerala (GoK). (2015). 'Economic review.' State Planning Board, Kerala.

Hall, G. and Patrinos, H. A. (eds.). (2005). Indigenous Peoples, Poverty and Human Development in Latin America. New York: Palgrave Macmillan. [Accessed August 2013] Available at : <http://elibrary.worldbank.org/docserver/download/9781403999382. pdf? expires $=1376879231 \&>$

Jackson, C. and Pearson, R. (eds.). (1998). Feminist Visions of Development: Gender Analysis and Policy. London: Routledge.

Kabeer, N. (2005). 'The search for inclusive citizenship.' In: Kabeer, N. (ed.), Inclusive Citizenship - Meaning and Expression, pp. 1-3. London: Zed Books Ltd.

Kalathil, M. (2004). 'Withering Valli: Alienation, degradation and enslavement of tribal women in Attapady.' Discussion Paper 66. Kerala Research Programme on Local Level. The Centre for Development Studies; Thiruvananthapuram, India.

Kurien, J. (1995). 'The Kerala model: Its central tendency and the outlier.' Social Scientist. 23(1-3), pp. 70-90.

Laclau, E. (1996). Emancipation(s). London: Verso.

Lareau, A. (1989). Home Advantage: Social Class and Parental Involvement in Elementary Education. London: Falmer.

Lawler, S. (2004). 'Rules of engagement: Habitus, power and resistance.' The Sociological Review, 52(s2), pp. 110-128.

Maclean, K. (2010). 'Capitalizing on women's social capital? Women-targeted microfinance in Bolivia.' Development and Change, 41(3), pp. 495-515.

Marshall, T. H. (1992[1950]). 'Citizenship and social class.' In: Marshall, T. H. and Bottomore, T. (eds.). Citizenship and Social Class, pp. 8-17. London: Pluto Press.

Lister, R. (2001). Citizenship: Feminist Perspectives. New York: Palgrave Macmillan.

McKnight, D. and Chandler, P. (2012). 'The complicated conversation of class and race in social and curricular analysis: An examination of Pierre Bourdieu's interpretative framework in relation to race.' Educational Philosophy and Theory, 44(s1), pp. 74-97.

McNeish, J. A. and Eversole, R. (2006). 'Introduction - indigenous people and poverty.' In: Eversole, R., McNeish, J. A. and Cimadamore, A. D. (eds.), Indigenous People and Poverty: An International Perspective, pp. 1-27. (International Studies in Poverty Research). London: Zed Books Ltd.

Miles, R. (1982). Racism and Migrant Labour. London: Routledge and Kegan Paul.

Mills, C. (2003). From Class to Race: Essays in White Marxism and Black Radicalism. Oxford: Rowman \& Littlefield Publishers.

Moore R. (2008). 'Capital.' In: Grenfell, M. (ed.), Pierre Bourdieu: Key Concepts, pp. 101-117. Stocksfield, UK: Acumen.

Moser, C. O. N. (1998). 'The asset-vulnerability framework: Reassessing urban poverty reduction strategies.' World Development, 26(1), pp. 1-19.

Moser, C. O. N. and Dani, A. A. (2008). Assets, Livelihoods and Social Policy. Washington, DC: World Bank.

Mouffe, C. (ed.) (1992). Dimensions of Radical Democracy: Pluralism and Citizenship. London: Verso Books.

Mukhopadhyay, S. (2007). The Enigma of the Kerala Woman: A Failed Promise of Literacy. New Delhi: Social Science Press.

Narayan, D., Patel, R., Schafft, K., Rademacher, A. and Koch-Schulte, S. (2000). Voices of the Poor: Can Anyone Hear Us? Washington, DC: World Bank Publication. 
Oldfield, A. (1990). 'Citizenship: An unnatural practice?' The Political Quarterly, 61(2), pp. 177-187.

Ravi Raman, K. (2002). 'Breaking new ground: Adivasi land struggle in Kerala.' Economic and Political Weekly. [online] 9-15 March, 37(10). [Accessed on 19 August 2013] Available at: $<$ www.jstor.org/discover/10.2307/4411834?uid=2\&uid=4\& sid $=21102564293743>$.

Reay, D. (2004). 'It's all becoming a habitus: Beyond the habitual use of habitus in educational research.' British Journal of Sociology of Education, 25(4), pp. 431-444.

Reynolds, T. (2006). 'Caribbean families, social capital and young people's diasporic identities.' Ethnic and Racial Studies, 29(6), pp. 1087-1103.

Rex, J. (1970). Race Relations in Sociological Theory. London: Weidenfeld and Nicolson

Rollock, N. (2012). 'The invisibility of race: Intersectional reflections on the liminal space of alterity.' Race Ethnicity and Education, 15(1), pp. 65-84.

Rowse, T. (2000). 'Transforming the notion of the urban Aborigine.' Urban Policy and Research, 18(2), pp. 171-190.

Said, E. (1978). Orientalism. New York: Pantheon.

Sen, A. (1999). Development as Freedom. Oxford: Oxford University Press.

Shreekumar, S. (2007). "The land of "Gender Paradox"? Getting past the commonsense of contemporary Kerala.' Inter-Asia Cultural Studies, 8(1), pp. 34-54.

Silva, E. B. (2005). 'Gender, home and family in cultural capital theory.' The British Journal of Sociology, 56(1), pp. 83-103.

Soysal, Y. N. (1994). Limits of Citizenship: Migrants and Postnational Membership in Europe. Chicago: University of Chicago Press.

Sreekumar, T. T. and Parayil, G. (2006). 'Interrogating development: New social movements, democracy and indigenous people's struggles in Kerala.' In: Tharamangalam, J. (ed.), Kerala: The Pardoxes of Public Action and Development, pp. 215-257. New Delhi: Orient Longman.

Steur, L. (2010). '14 Adivasi workers' struggles and the Kerala model.' Development, Democracy and the State: Critiquing the Kerala Model of Development, 28, p. 221.

Swartz, D. (1997). Power and Culture: The Sociology of Pierre Bourdieu. Chicago: The University of Chicago Press.

Tornquist, O. (2000). 'The new popular politics of development: Kerala's experience.' In: Parayil, G. (ed.), The Development Experience: Reflections on Sustainability and Replicability, pp. 116-138. London: Zed Books.

Turner, B. (1997). 'Citizenship studies: A general theory.' Citizenship Studies, 1(1), pp. 5-18.

Vincent, C., Rollock, N., Ball, S. and Gillborn, D. (2012). 'Being strategic, being watchful, being determined: Black middle-class parents and schooling.' British Journal of Sociology of Education, 33(3), pp. 337-354.

Walby, S. (1994) Is citizenship gendered? Sociology, 28(2), pp. 379-395.

Wallace D. O. (2016). 'Re-interpreting Bourdieu, belonging and black identities: Exploring 'Black' cultural capital among black Caribbean youth in London.' In: Thatcher, J., Ingram, N., Burke, C. and Abrahams, J. (eds.), Bourdieu: The Next Generation: The Development of Bourdieu's Intellectual Heritage in Contemporary UK Sociology, pp. 37-54. Abingdon and New York: Routledge.

Woolcock, M. J. V. and Narayan, D. (2000). 'Social capital: Implications for development theory, research and policy.' The World Bank Research Observer, 15(2), pp. 225-249.

Yosso, T. J. (2005). 'Whose culture has capital? A critical race theory discussion of community cultural wealth.' Race, Ethnicity and Education, 8(1), pp. 69-91. 


\section{Conclusion}

Émile Durkheim's use of anomie in Suicide (1897) points to how forces of modernity namely the division of labour and social change - lead to the decline of shared values, individualistic pursuits, the bringing about of alienation and the disintegration of social bonds. For Bourdieu, a similar phenomenon also occurs in society: "hysteresis", which he defined as a disjuncture between habitus and fields, but one that can be addressed through reflexivity - the key to transformation. This phenomenon occurs through 'a form of monitoring which would exclude the bias not just of the dominant class, but also that of the dominant gender and ethnic group' (Fowler, 2000, p. 13). Feminist theorists have drawn on Bourdieu's reflexive sociology through his analysis of the sexual division of labour in maintaining capital, which in this context concerns/means or other social reproduction (see Lovell, 2000). This study, by engaging a feminist-Bourdieusian framework, explores sites of reproduction within Kerala society and highlights the ambivalent role of gender capital within the hegemonic narrative of development.

As seen in Chapter 3, the Kerala model of development, as a reasonably successful experiment, was very much lauded in both academic debates and by development agencies until the mid-1990s; since then, much scholarship, from various standpoints, has scrutinised the limitations of the dominative narrative. Critiquing the Kerala model, Ravi Raman (2010) draws attention to three issues: the widening inequalities among social groups; asymmetry of power relations; and the emergent challenges of globalisation. This book explores concerns on the "anomie" of the Kerala experience in both interpretation and the lived social reality of its women in Kerala society, nestled within asymmetries of power and inequalities, and accentuated in a global context. Here, anomie does not refer to the normlessness, rather points to the incongruity of norms and bias that legitimises or limits forms of capital through perpetual forms of social construction of gender roles and hierarchies in the Kerala society. In reality, gender equality remains a challenge, for both India and Kerala.

The claims of a progressive state with "empowered" women sit uncomfortably alongside the rising levels of misogyny, particularly targeting women in public spheres, both through direct and online abuse. Some examples include: the denigratory statements of the film director Major Ravi against a renowned TV journalist based on her reporting of the controversial presentation of the Goddess Durga; 


\section{Conclusion}

online abuse targeted at the TV presenter Ranjani Haridas, who is seen as a "liberated", "modern" Malayalee woman; ongoing protests against calls for women's entry into the Sabarimala Temple; public hostility towards the actress Manju Warrier, who divorced her husband (while their daughter preferred to remain with her father) and returned to work in the film industry. The tone of such misogyny points to the notions of non-conformity of "progressive" Malayalee women to Bharatheeya (Indian) ideals of domesticity, modesty and conservative religious values. Thus, the Kerala woman is still seen as an important capital-bearing object, and she exists within a gendered relationship with the hegemonic feminine narrative in terms of her identity, presence, participation and representation. In this last chapter, I discuss some of this study's major findings and their relevance for situating gender relations within the acclaimed social experiment.

\section{The relevance of gender capital within the Keralan context}

The Global Gender Gap Index, which captures the magnitude of gender-based disparities in the economy, education, health and political representation, placed India in the 108th position in 2016 (see The Global Gender Gap Report, 2016), with one of the country's glaring gender differences being in the gender wage gap (over 30 per cent). Despite closing gaps in education in the country, occupational segregation due to women's educational choices and undervaluing of women's work were cited as the main reasons. In particular, the report notes how a large majority of women took up nursing, where care work is undervalued and seen as a natural female attribute. Such notions of work and labour markets can be attributed to social constructions of work, gender and social relations seen as a global and national phenomenons, and Kerala is no exception.

The concept of gender as capital, drawn from Bourdieusian feminists (e.g. McCall, 1992; Huppatz, 2009; 2012) is a useful tool for understanding contemporary gender practices in Kerala, where differentiating forms of female and feminine capital helps evaluate the extent to which gendered capital operates in different fields. The term "gender capital" (see Huppatz, 2009) places more importance on forms of feminine and embodied capital than on the social constructions of gendered roles and behaviours. This concept moves beyond the framework of patriarchy, gravitating to Bourdieu's "forms of capital" - a term that encapsulates how social constructions of masculinity or femininity in private and public domains are subject to processes of valuation, accumulation or even devaluation. The notion of gender capital is particularly useful in the Kerala context, as the Malayalee woman is well noted for her female capital through notions of equality and autonomy, and she has been instrumental in achieving the Kerala model of development as a form of "human and cultural capital". This study has focussed on the female and feminine notions of gender capital, although some social domains such as labour markets and narratives of violence do expose masculine notions of gender capital. More research into this is required. As seen in Chapter 4, female capital has been advantageous to the hegemonic narrative of development, in the Kerala context - where the feminine cultural capital is 
valued through the practices of matriliny, cultural practices and relative social mobility, and one that has achieved higher levels of human capital which can foster equality in education and physical capabilities. However, the female body (and capital) has been aligned with femininity and feminine traits (including their sexual bodies), but this body has been both privileged and confined to the private sphere. Notions of femininity and feminine traits have been simultaneously devalued or disadvantaged in the public sphere, as they have become 'feminine selves, with limited conversion' (see Huppatz, 2012) in a place where masculine traits of domination, power and aggression dominate the higher echelons of political and economic power. This resonates with Devika and Thampi's (2010) observation that women's induction into the public sphere, such as in local governance bodies, has forced them to adopt an approach of "honorary masculinity". So while the Malayalee woman have capital through their higher literacy rate and other social capabilities, which are key to family and social welfare, the hegemonic Kerala model has not come to accommodate or value her feminine capital; at times, this even leads to a loss or erosion of gender capital - as evinced through violence against women and girls. Further, increasing patriarchal norms, such as dowry and the centrality of marriage (e.g. see Kodoth, 2008), patrilocal practices and domestication limit women's autonomy and reifies hegemonic notions of womanhood.

Simone de Beauvior's (1949, p. 293) maxim that 'one is not born, one becomes a woman' is apt to contextualise issues that affect and transform women in developing contexts such as Kerala. Women in Kerala society have been symbolised by progressive "embodied female capital" with favourable demographic indicators, unique matrilineal systems and social progress. The social meanings and values attached to social constructs are constitutive of social hierarchies which determine the materiality of social contexts through distribution of power and resources. Evidence of women's persistent marginalisation through de-feminisation of the labour force, invisibility in public spheres and rising violence against them resonate to some extent, with Amartya Sen's (1992) thesis of the "missing women", where the Malayalee women are "missing" in Kerala society through their presence and full participation in the economic and political spheres. Their lack of effective participation signifies a "devaluation" of the female capital through rising patriarchal practices, neo-liberal market forces and widening social differences within the hegemonic model. The celebrated sex ratio in favour of women does not hold the same in favour of girls under age six, pointing to concerns about imminent "missing" girls. Thus while the acclaimed model has indeed enhanced, and benefitted from, its "female capital", it has not necessarily enhanced women's autonomy, both within the private and public spheres.

\section{Gender, asset and autonomy}

The concept of habitus and the value of capitals depend on the field (context) of practice, as each agent's habitus is also heavily structured by its relational position within wider relationships and structures of social difference: nation, class, caste (in India), gender, ethnicity etc. The development of feminist habitus has been 


\section{Conclusion}

useful to parse the confluence of capital, gender equality and development contexts. Foremost is how gender has important but varying interactive effects with capital, and thus female autonomy. The intra- and inter-household dimensions of gender equality has been a prime concern of development feminists (e.g Elson, 1995). In Kerala, the overall embodied nature of the female capital, through education and literacy, translates into intergenerational transmission (IGT) of capital through values and norms regarding gender equality in the household. Females gaining property ownership through inheritance can bring increased income and some control, reducing domestic violence, but it is often a collective asset with no individual decision-making power being bestowed in the context of matrilocal and matrilineal practices. Such property rights are increasingly seen as forms of dowry, which has significant bearing on gender relations.

Changing cropping practices in the context of commercialistion and de-agrarianisation have reduced women's control, accelerated through patrilineal practices within households, for example, through male ownership of property and patrilocal practices. Landless female labourers may not enjoy autonomy such as decision-making in the households but their participation in collective networks such as SHGs, particularly through group farming, increase social capital, networks, presence and participation in the public sphere. Thus, a combination of economic capital and access to independent forms of capital, such as paid employment and social networks, is more significant as this also aids collective bargaining power, achievement of wider social goals and gender equality. Asset ownership is an important determinant of the "fallback" position within the household, both in terms of decision-making and exit (Quisumbing and Hallman, 2006). However ownership of property can reduce incidences of physical violence because of those very matrilocal factors, such as the increased presence of natal families. Other studies show that asset ownership may help women live without domestic violence (Friedemann-Sanchez, 2006; Agarwal and Panda, 2007). As Chapter 4 showed, women in semi-rural contexts are, to a certain degree, endowed with good levels of female capital (primarily human capital such as education), including access to and control of economic capital, but they are often subject to gender and social norms (Arun, 2012).

\section{Social capital as capital of "poor" and "women"}

The role of SHGs as a form of social capital, particularly among poorer women, does demonstrate contradictions. Within development debates, there has been much euphoria on how SHGs use group enterprises as a panacea for achieving women's empowerment and reducing poverty, although this has been subject to much scrutiny in terms of benefits to women. By drawing on how indigenous women participate in a micro-finance initiative in Bolivia, Maclean (2013) shows how micro-finance typifies gendered and colonial constructions of risk and responsibility that underpin a neo-liberal agenda. Women from poor and marginalised communities take on responsibility for "risk", thus earning rewards and profits. In this study also, it is seen that women were pushed into further economic 
patriarchy through increased work, higher levels of debt, group rivalry and domination of political leadership at the local level. However, there was evidence that collective or group consciousness of women acts as a conduit for both social and economic agency, and it can improve the collective economic resources that, in a small way, can address negative shifts to non-farming practices and sales of farmland. To some extent local SHGs provide an important political and economic space for women, particularly those from landless and marginal rural households where different forms of capital are activated, legitimised and transferred within and beyond households. Such collective participation in the public sphere also enables the achievement of wider goals such as sustainable food cultivation, gender equality and environmental sustainability, all of which are key concerns for Sustainable Development Goals (SDGs). In all, development agendas that focus on women's participation should move away from mere physical notions of networks. These should acknowledge the wide array of gendered, political and cultural barriers to women's effective participation in the public sphere. Research has shown that obstacles include social norms on gendered behaviours, social perceptions on their abilities, personal endowments such as women's education and property ownership status, and household attributes such as caste and class (Agarwal, 2010, p. 177).

\section{Limits to capital: ruptures and reproduction in a global field}

The context of Kerala is a conundrum by itself, in terms of its historical and its contemporary processes, as it offers both opportunities and challenges in the milieu of global change vis-à-vis mobilities, diversification of livelihoods and linkages to the information society. By viewing women 'as capital-accumulating subjects' (Lovell, 2000, p. 37), we see that to some extent women capitalised on their female and feminine capital by entering into economic employment in the service sector or pursuing migrant routes through occupations in the care and service sectors, through the operation of gendered cultural capital (see Chapters 5 and 6).

The use of habitus and capitals in the realm of knowledge work has enabled the activation of different forms of capitals, where we see women's lived experiences, contested and negotiated within the limits of masculine power, as seen in Chapter 5. In IT-related professions - especially those that offer powerful and well-paid positions - gender power relations and the doxic order nullify their strategic usefulness, as masculine and male capitals continue to prevail (see Skeggs, 1997). For example, the ability to activate capital in the knowledge economy is gendered and shaped not merely by human capital but by other forms of gender capital, including emotional skills, knowledge and experience. As other studies have shown, simply gaining access to the knowledge worksphere does not lead to women's empowerment - this requires changes to gendered notions of work and power (e.g. Fuller and Narasimhan, 2008). Despite high levels of human capital and middle-class backgrounds, women have not been able to break the glass ceiling because of the regimes of flexibility in IT software production and work 
conditions within call centres. Rather, such forms of working lead to emotional burnout and alienation. Besides, social (and gendered) identities in transnational sites of work are caught in debates on changing notions of femininities (and masculinities), whereby gender capital that is and seen to be challenged and shaped by marked Westernisation and Western imperialism and also, to some extent, nationalistic notions of bodily politics. To some extent, women have been able to circumvent pressures of domesticity by outsourcing household chores and drawing from increased consumerist cultures. As Friedman (2012) notes, there are constant social, cultural and emotional challenges for those aspiring to be upwardly mobile, even for those with much endowed capital. For Huppatz (2012), gender capital has limited use-value simply because femininity is a cultural resource that can be used only in tactical rather than strategic ways to achieve gender equality and autonomy. Incorporating women's interests seems to be fractured terrain because of widening gender inequalities, which have been made more severe through the weaknesses of the globally linked economy and growth.

\section{Emotional capital at work}

The simultaneous pressures of domesticity and neo-liberal forms of work practices can lead to perpetual emotional pressures on women, particularly in their constant quest for the economic and cultural capital that enables inter-generational mobilities and aspirations. Often working middle-class mothers are surveyed through the "gaze" of their children's educational performance. It also relates to Reay's (2004) inference of Bourdieu's conception of practical and symbolic work, which generates devotion and generosity and altruism, seen mostly as women's responsibility in intra-household relations. Yet the "branding" or "label" of "IT work" was a form of cultural capital that women within IT-based SHGs acquired by investing much emotional capital through their own time, emotions and struggles to maintain these enterprises. Yet many women felt that they faced hostility from employees of the different departments for which they undertook work, leading to emotional distress and low self-esteem. As Colley (2006) notes, emotional work is no longer a source of human bonding and satisfaction, but of alienation and eventual emotional burnout. This perpetuates and reproduces differences not only between men and women but also among women through inequitable possession and their activation of economic, cultural and social capital bringing unequal outcomes.

Global migration, particularly that of skilled female migrants, is indeed an outcome of the Kerala model of development (manifested as "embodied female capital") with its higher levels of female literacy, aspiration for social and intergenerational mobility, and a measure of gender empowerment. This calls for further investigation into forms of gendered capital (i.e. female, feminine and masculine) and the classed and the religious, post-colonial and racial forces that influence the formation of gendered habitus. Gendered migration also intersects with different historical trajectories of migrations and with social constructions of care and body work, where the habitus is tested while striving to "fit in" the field, 
thus transforming their migrant habitus and gendered capital. Thus, migrants are thrust into the "game" through "rules" and interactions, competing and struggling over the game's "stakes", or rewards, such as relative social and inter-generational mobility.

Migration and mobilities propel change and rupture an individual's habitus testing its durability and capability (Thatcher and Halvorsrud, 2016) or making it transform and reinvent itself (Clayton et al., 2009). Migrants, particularly skilled migrants, come with a set of resources or various forms of capital that they bring with them and that can be accumulated, transferred or lost in new settings. The evidence of Kerala migrants, particularly women - who are seen as embodied female capital and are endowed with human capabilities such as education, language and professional qualifications - shows that they are indeed a valuable economic and social resource not only within the Kerala context but also in the global sphere. Such evidence illustrates narratives of resilience, adaptation and transformation, where they simultaneously rupture and transform "habitus clivé". Kerala's increased feminisation of migration, mostly in the form of skilled nurses, is indeed an outcome of the Kerala model of development, but it is one that is manifested as "embodied female capital", with its higher levels of female literacy, aspiration for social and inter-generational mobility, and gender empowerment. But such forms of gendered capital (as female, feminine and masculine capital) interact with classed (status) and religious and post-colonial (and racial) forces that rupture and transform gendered habitus, as seen in Chapter 6. Thus, gendered migration intersects with different historical trajectories of migrations but also with persistent social constructions of care and body work, where the habitus is put to the test while striving to "fit in" the field and transforming migrant habitus and gendered capital.

\section{The complicity and symbolic violence of gender in everyday life}

Patriarchy - irrespective of its various forms - cannot be seen as the mere domination of one party over another, as such gender domination occurs because both parties misrecognise the symbolic violence they practise or are subject to, so they complicitly reproduce dominant practices. In a way, then, symbolic violence is 'the violence exercised upon a social agent with his or her complicity' (Bourdieu and Wacquant, 1992, p. 167). Kerala's matrilineal systems of kinship practice that allow Nair women to inherit property, or continue to live in natal homes after marriage (a common feature of matrilocal practices), have gained much attention and been noted as a key factor in women's status in the Kerala society. However, research shows that such kinship and family structures and ideologies have upheld dominant norms of femininity and domesticity (Kodoth and Eapen, 2005) through the dominance of the karanavar (maternal uncle). The social, economic and political changes that occurred through the breakdown of the joint family system, demographic profile and the rise of agrarian capitalistic tendencies during the nineteenth and early twentieth century transformed Nair women's identity, security and autonomy (Jeffrey, 1976; Saradamoni, 1999), furthering and 
normalising patriarchal practices and thus changing women's status within the household. Symbolic domination is still evident and implies complicity from the dominated, as it 'can only be exerted on a person predisposed (in his habitus) to feel it, whereas others will ignore it' (Bourdieu, 1991, p. 51). This complicity can happen only when both agents - the dominant and the dominated - have integrated into their habitus the symbolic order that generates the corresponding actions.

Overall, violence against women in Kerala is increasing, and the concept of symbolic violence has been useful in drawing out both elementary and other modes of domination through interactions at the meso-micro and macro levels. All these clearly pinpoint to the erosion of female and feminine capital (see Huppatz, 2009) in the public and private spheres, and devaluation of the Kerala woman and girl through increasing cases of sexual violence that is caught within politics of institutional silencing, male domination and patriarchal structures. In addition to this, the female capital and feminine capital have been subject to much symbolic (and physical) violence through acts of domestic and sexual violence in Kerala. Thus while women certainly do utilise gender capital, theirs is a capital that always operates within social norms, constraints and disadvantages.

\section{The misrecognition of capital}

Much scholarship pinpoints to a long history of deficit understandings in terms of resources and capital possessed by minority groups such as non-whites in Western societies (see McKnight and Chandler, 2012). Osella and Osella (2000) have shown how, in the Kerala context, marginalised groups such as Ezhavas have gained social mobility by accumulating economic, symbolic and cultural capital, yet inequalities do persist, for example, in caste and gender relations (see Lindberg, 2001). The persistent structure of domination upheld in the Kerala model of development is perpetuated through Bourdieu's "symbolic violence". In this work's context we see how Adivasi identity and cultural capital is non-existent within the Kerala model, except through their struggles and incapacities, such as with their poor quality of life. By acquiring different forms of capital, dominant agents in the Kerala model maintain the ability to reproduce their dominance, through the operation of "doxa". The striking observation is that well-endowed female capital (through literacy and autonomy) of the Kerala woman is not necessarily parallel to that of the Kerala Adivasi woman on many levels, such as social, economic and political equality. Much more concerning is the structural violation of the Adivasi identity and body, through both exploitation and sexual abuse. Thus the Kerala model not only has generated a range of outliers (Kurien, 1995), it does not accommodate both the female and feminine capital of marginalised women such as Adivasis. This is largely because, as in other contexts, Adivasi cultural capital does not conform to conventional interpretations of mainstream capital, thus promoting deficit perspectives of capital fed into development paradigms. Chapter 8 shows that citizenship rights for Adivasis in Kerala are vigorously contested with disempowering experiences of rights, and they are shaped through 
actual struggles and experiences, with asymmetrical power relationships in society questioning the mere membership of its political community.

As Bebbington (2007) proposes, it may be necessary to draw on and build the required alliances to deliver emancipatory agendas based on social capital approaches. In a similar vein, Krais (2006) calls for a refashioning of gender in the dominant classes (see Adkins, 2004), arguing that 'profound social change results not from a revolt of the great individual, but from the political action of many individuals: from social movements'. This social change is done by connecting Bourdieu's various reflections on class formation, which focus on the role of symbolic struggle, political organisation and political representation in helping social groups achieve recognition and assert their interests as feminist movements have achieved in relation to their political and legal rights over the past century. Kerala has been known for pioneering a number of social movements in relation to equality and justice. The state's recent initiative to employ a number of transgender workers in its new metro transport system is hailed as a move towards recognition of gender and transgender identities (The HindustanTimes, 2017).

Yet we must be reminded that though Kerala has had a long history of social mobilisation, women's participation within such movements has often been framed within ideologies succumbing to patriarchal domination, rather than defining their own feminist ideology or identity. In 2015, the mobilisation of women labourers at the Kannan Devan Hills Plantations saw them gaining reluctant support of the main political parties and trade union, and showing how imperative it is for women to make use of their agency and capital to mobilise together for collective feminist goals. As noted, the Munnar mobilisation indicates a departure from the dominant political narrative of Kerala through underlining the gender dimension of working-class social protest, labelled as Pembila Orumai (Unity of Women), and expressing a strong presence through their trade union membership, baring the patriarchal nature of the state's trade union politics (The Indian Express Online, 2015). While trade union movements have played an important role in Kerala's social reforms and politics, women, as active agents, are emerging as strong players in recent mobilisation strategies, demonstrating resistance to women's subordinated position within the labour market (ibid.) and fighting for their own rights.

If any, attitudes to and practices on gender relations in Kerala reflect diplopia or double vision. In this sense and context, this relationship is the simultaneous perception of two images of Kerala women: one in relation to men and another in relation to each other. In addition, diplopia is a not a recent phenomenon. Manu Pillai's (2015) Chronicles of the House of Travancore is a narration of Maharani Sethu Bayi's initiation of feminism in Travancore through promoting women in education, legal and political spheres since the early twentieth century. Despite exemplary performance in fields, these women were often met with criticism and resistance, from both men and women. Citing Jeffrey (1987), Pillai notes how 'by the end of her reign, it was universally lamented that the great majority of girls regarded their education not as something of cultural value in itself, but as a direct means of securing employment and competing with men in the open 
market' (ibid., p. 282). Whilst efforts by princely rulers, state policies as well as social practices have strived to promote equal footing for women compared to men, notions that such steps to improve women's capital must serve as an end in itself, or for the sake of family, rather than a means to increase their presence in the public sphere still prevail.

The tool of gender capital serves to explore how the forms of gender capital are subject to limits, resistance and even violence in both the private and public domains of Kerala. The systemic and cultural practices of gender hierarchies and norms have meant that women have had varying success in their interaction within various domains, such as the household and labour market and in their relations with the community and the state. Notions of masculinity and femininity, as social constructions, are accentuated through their social locations (ethnicity, class etc), and these are simultaneously valued and devalued, shedding light on forms of conflict, change, continuity or reproduction. Discourses on equality and development, drawing on the dominant narrative of the Kerala model, should move beyond a mere rhetoric of gender equality or autonomy. As presently evinced through the "politics of representation" of the Kerala women through development debates and equality indices, a more embedded "politics of transformation" is required that meaningfully recognises, absorbs and transforms its gender capital in a wider social and global system.

\section{References}

Adkins, L. (2004). 'Introduction: Feminism, Bourdieu and after.' The Sociological Review, $52(\mathrm{~s} 2)$, pp. 1-18.

Agarwal, B. (2010). Gender and Green Governance: The Political Economy of Women's Presence Within and Beyond Community Forestry. Oxford: Oxford University Press.

Agarwal, B. and Panda, P. K. (2007). 'Toward freedom from domestic violence: The neglected obvious.' Journal of Human Development, 8(3), pp. 359-388.

Arun, S. (2012). 'We are farmers too: Agrarian change and gendered livelihoods in Kerala, South India.' Journal of Gender Studies, 21(3), pp. 271-284.

Bebbington, A. (2007). 'Social capital and development studies II: Can Bourdieu travel to policy? Progress in Development Studies, 7(2), pp. 155-162.

Bourdieu, P. (1991). Language and Symbolic Power (G. Raymond and M. Adamson, Trans.). Cambridge: Polity Press.

Bourdieu, P. and Wacquant, L. J. (1992). An Invitation to Reflexive Sociology. Chicago and London: University of Chicago Press.

Colley, H. (2006). 'Learning to labour with feeling: Class, gender and emotion in childcare education and training.' Contemporary Issues in Early Childhood, 7(1), pp. 15-29.

Clayton, J., Crozier, G. and Reay, D. (2009). 'Home and away: Risk, familiarity and the multiple geographies of the higher education experience.' International Studies in Sociology of Education, 19(3-4), pp. 157-174.

De Beauvoir, S. (1974). The Second Sex (H. M. Parshley, Trans. and Ed.). New York: Vintage Books.

Devika, J. and Thampi, B. V. (2010). 'Empowerment or politicization? The limits of gender inclusiveness of Kerala's political decentralisation.' In: Ravi Raman, K. (2012). 
Development, Democracy, and the State: Critiquing the Kerala Model of Development, pp. 177-191. London: Routledge.

Durkheim, E. (1897) [1951]. Suicide: A Study in Sociology. The Free Press.

Elson, D. (1995). Male Bias in the Development Process (2nd Edition). Manchester: Manchester University Press.

Fowler, B. (2000). Reading Bourdieu on Society and Culture. Oxford and Malden, MA: Blackwell Publishers/The Sociological Review.

Friedemann-Sánchez, G. (2006). 'Assets in intrahousehold bargaining among women workers in Colombia's cut-flower industry.' Feminist Economics, 12(1-2), pp. 247-269.

Fuller, C. J. and Narasimhan, H. (2008). 'From landlords to software engineers: Migration and urbanization among Tamil Brahmans.' Comparative Studies in Society and History, 50(1), pp. 170-196.

The Global Gender Gap Report. (2016). The Global Gender Gap Report. Geneva: World Economic Forum.

The Hindustan Times. (2017). Kerala: In a first, Kochi Metro to employ 23 transgenders. [Accessed June 2017] Available at: <www.hindustantimes.com/india-news/kerala-in-afirst-kochi-metro-to-employ-23-transgenders/story-52WRY2ees5fo6hEnkVsukI.html>

Huppatz, K. (2009). 'Reworking Bourdieu's capital: Feminine and female capitals in the field of paid caring work.' Sociology, 43(1), pp. 45-66.

Huppatz, K. (2012). Gender Capital at Work: Intersections of Femininity, Masculinity, Class and Occupation. London: Palgrave Macmillan.

The Indian Express Online (2015). 'What Munnar Rebellion Says About Kerala's Women Labour'. September 18. [Accessed January 2017] Available at: <http://indianexpress. com/article/explained/what-munnar-rebellion-says-about-keralas-women-labour/>.

Jeffrey, R. (1976). The Decline of Nayar Dominance: Society and Politics in Travancore, 1847-1908. London: Sussex University Press.

Jeffrey, R. (1987). 'Governments and culture.'P Pacific Affairs, 60(3), p. 466.

Kabeer, N. (1994). Reversed Realities: Gender Hierarchies in Development Thought. London: Verso Books.

Kodoth, P. (2008). 'Gender, caste and matchmaking in Kerala: A rationale for dowry.' Development and Change, 39(2), pp. 263-283.

Kodoth, P. and Eapen, M. (2005). 'Looking beyond gender parities, gender inequalities of some dimensions of well being in Kerala.' Economic and Political Weekly, 40(30), pp. $3278-3286$.

Krais, B. (2006). 'Gender, sociological theory and Bourdieu's sociology of practice.' Theory, Culture and Society, 23(6), pp. 119-134.

Kurien, J. (1995). 'The Kerala model: Its central tendency and the outlier.' Social Scientist, 23(1-3), pp. 70-90.

Lindberg, A. (2001). Experience and Identity: A Historical Account of Class, Caste and Gender among the Cashew Workers of Kerala, 1930-2000. Sweden: Lund University.

Lovell, T. (2000). 'Thinking feminism with and against Bourdieu.' Feminist Theory, 1(1), pp. 11-32.

Maclean, K. (2013). 'Gender, risk and micro-financial subjectivities.' Antipode, 45(2), 455-473.

McCall, L. (1992). 'Does gender fit? Bourdieu, feminism, and conceptions of social order.' Theory and Society, 21(6), pp. 837-867.

McKnight, D. and Chandler, P. (2012). 'The complicated conversation of class and race in social and curricular analysis: An examination of Pierre Bourdieu's interpretative framework in relation to race.' Educational Philosophy and Theory, 44(s1), pp. 74-97. 


\section{Conclusion}

Osella, F. and Osella, C. (2000). Social Mobility in Kerala: Modernity and Identity in Conflict. London: Pluto Press.

Pillai, M. S. (2015). Ivory Throne: Chronicles of the House of Travancore. New Delhi: Harper Collins

Quisumbing, A. and Hallman, K. (2005). 'Marriage in transition: Evidence on age, education, and assets from six developing countries.' In: Lloyd, C. B., Behrman, J. R., Stromquist, N. P. and Cohen, B. (eds.), The Changing Transitions to Adulthood in Developing Countries: Selected Studies, pp. 200-269. Washington, DC: The National Academies Press.

Reay, D. (2004). 'It's all becoming a habitus': Beyond the habitual use of habitus in educational research.' British Journal of Sociology of Education, 25(4), pp. 431-444.

Ravi Raman, K. (ed.). (2012). Development, Democracy and the State: Critiquing the Kerala Model of Development. London: Routledge.

Saradamoni, K. (1999). Matriliny Transformed: Family, Law and Ideology in Twentieth Century Travancore. New Delhi: SAGE Publications.

Sen, A. (1992). 'Missing women.' BMJ: British Medical Journal, 304(6827), p. 587.

Skeggs, B. (1997) 'Classifying Practices: Representations, Capitals and Recognitions.' In: Mahony, P. and Zmroczek, C. (eds.), Class Matters: 'Working-class Women's Perspectives on Social Class', pp. 123-139. London: Taylor \& Francis.

Thatcher, J. and Halvorsrud, K. (2016). 'Migrating habitus.' In: Thatcher, J., Ingram, N., Burke, C. and Abrahams, J. (eds.), Bourdieu: The Next Generation: The Development of Bourdieu's Intellectual Heritage in Contemporary UK Sociology, pp. 88-106 Abingdon and New York: Routledge. 